\title{
Stream Restoration: Project Evaluation and Site Selection in the Cacapon River Watershed, West Virginia
}

\author{
Jonathan L. Pitchford \\ West Virginia University
}

Follow this and additional works at: https://researchrepository.wvu.edu/etd

\section{Recommended Citation}

Pitchford, Jonathan L., "Stream Restoration: Project Evaluation and Site Selection in the Cacapon River Watershed, West Virginia" (2012). Graduate Theses, Dissertations, and Problem Reports. 3599.

https://researchrepository.wvu.edu/etd/3599

This Dissertation is protected by copyright and/or related rights. It has been brought to you by the The Research Repository @ WVU with permission from the rights-holder(s). You are free to use this Dissertation in any way that is permitted by the copyright and related rights legislation that applies to your use. For other uses you must obtain permission from the rights-holder(s) directly, unless additional rights are indicated by a Creative Commons license in the record and/ or on the work itself. This Dissertation has been accepted for inclusion in WVU Graduate Theses, Dissertations, and Problem Reports collection by an authorized administrator of The Research Repository @ WVU.

For more information, please contact researchrepository@mail.wvu.edu. 
Stream Restoration: Project Evaluation and Site Selection in the Cacapon River Watershed, West Virginia

Jonathan L. Pitchford

Dissertation submitted to the

Davis College of Agriculture, Natural Resources, and Design

at West Virginia University

in partial fulfillment of the requirements for the degree of

Doctor of Philosophy

in

Forest Resources Science

James T. Anderson, Ph.D., Major Advisor

LianShin Lin, Ph.D., Co-Advisor

Michael P. Strager, Ph.D., Committee Member

J. Steven Kite, Ph.D., Committee Member

George Merovich, Ph.D., Committee Member

Division of Forestry and Natural Resources

Morgantown, West Virginia

2012

Keywords: Cacapon River, stream restoration, streambank migration, maximum entropy, West Virginia 


\section{ABSTRACT \\ Stream Restoration: Project Evaluation and Site Selection in the Cacapon River Watershed, West Virginia}

\section{Jonathan L. Pitchford}

Stream restoration is being conducted throughout the world at unprecedented rates to address stream channel degradation and water quality concerns. Natural Channel Design (NCD) is a common method used for restoration and has received governmental endorsement; however, the effects of NCD on channel stability and ecosystem functioning are poorly studied. We examined the effects of a reach-scale NCD project on channel stability, riparian vegetation, and water quality along the Cacapon River, West Virginia using a before-after-control-impact design and determined that restoration increased the abundance and diversity of woody vegetation, but had minimal effects on streambank stability and water quality. Increased erosion rates in some portions of the restored reach were attributed to differences in pre-restoration stability, vegetation removal, and soil composition among sub-reaches. No differences in in-stream concentrations of total phosphorus, nitrates, ammonia, or total suspended solids were detected following restoration; however, in-stream turbidity was drastically increased during construction. This study is a clear example of the value of monitoring streambank migration, vegetation communities, and soils to evaluate the effects of stream restoration and to provide insight on potential reasons for treatment failure. Ideally, pre-restoration monitoring should be used to inform project design by determining restoration potential of areas selected for restoration.

As a surrogate for process monitoring, we created a maximum entropy model of streambank erosion potential (SEP) in a Geographic Information System (GIS) framework to prioritize sites for management and to determine which variables in the watershed are associated with excessive rates of streambank erosion. Model development included measuring erosion rates throughout a central Appalachian watershed, application of a quantitative approach to locate target areas for management termed Target Eroding Areas (TEAs), and collection of environmental data throughout the study extent using high resolution, remotely sensed data. A likelihood distribution of TEAs from occurrence records and associated environmental variables over our study extent was constructed using the program Maxent. All model validation procedures indicated that the model was an excellent predictor of TEAs, and that the major environmental variables controlling these processes were streambank slope, soil characteristics, shear stress, underlying geology, and riparian vegetation. A classification scheme with low, moderate, and high levels of erosion potential derived from logistic model output was able to differentiate sites with low erosion potential from sites with moderate and high erosion potential. This type of modeling framework can be used in any watershed to address uncertainty in stream restoration planning and practice.

To address the need for accurate, high resolution estimation of streambank erosion, we also explored the role of laser scanning for estimating streambank migration and volumetric sediment loss. This was accomplished by comparing estimates of streambank migration and volumetric sediment loss derived from repeated erosion pin, streambank profile, and combined airborne and terrestrial light detection and ranging (LiDAR) surveys. Results indicated that LiDAR derived estimates were larger and highly variable compared to estimates derived from erosion pin and streambank profile surveys, which more accurately represented change along the study reach. Inflated LiDAR estimates were most likely the result of combining high resolution terrestrial LiDAR with relatively low resolution airborne LiDAR that could not effectively capture topographic features such as undercut banks. Although cost-prohibitive in some cases, repeated terrestrial LiDAR scans would likely circumvent these issues with higher point densities and better scan angles facilitating more accurate representation of streambank geometry, ultimately providing more accurate estimates of channel change. 


\section{ACKNOWLEDGMENTS}

I thank Dr. James T. Anderson for his patience and consistent support during my tenure as his graduate student. His mentorship and has been very helpful to me, and has provided me with a sense of confidence in my abilities as a scientist. Also, thanks to my co-advisor Dr. LianShin Lin, and other committee members Dr. George Merovich, Dr. J. Steven Kite, and Dr. Michael P. Strager for providing me with instruction, advice, and inspiration along this journey. Many others have assisted me over the last four years to whom I am greatly appreciative. These include: Gabriel Strain, Adam Riley, Aaron Maxwell, Daniel Hanks, Greg Estep, Brock Huntsman, Jesse De La Cruz, Steven Selego, Kathryn McCoard, Walter Veselka, Larry Pitchford, Dr. Andrew Colemen, Anthony Viafore, Cameron Eddy, Jeremy Mizel, Will Ravenscroft, Jerry Yates, Dr. Charles Yuill, Patricia Faulkner, Ishwar Dhami, Paul Ludrosky, Nancy Ailes, Ed Watson, Todd Miller, and many landowners who generously allowed me to work and camp on their land.

Also thanks to the National Fish and Wildlife Foundation (NFWF), Chesapeake Bay Trust, FishAmerica Foundation, National Oceanic and Atmospheric Administration (NOAA), Farm Service Agency (FSA), Natural Resource Conservation Service (NRCS), the West Virginia Department of Environmental Protection (WV DEP), West Virginia Conservation Agency (WVCA), Canaan Valley Institute (CVI), Cacapon and Lost Rivers Land Trust (CLRLT), and the employees of Reymann Memorial Farm in Wardensville, WV who provided funding and logistic support.

A final thanks to my parents Larry and Janice Pitchford who, as always, are supportive and encouraging to me when I need it most. Also thanks to my wife, Genevieve, who has endured several life changing events over the last several years, but has remained a source of encouragement, love, and support through it all. Finally, thanks to my daughter and little buddy Dawn for being a constant source of joy. 
Table of Contents

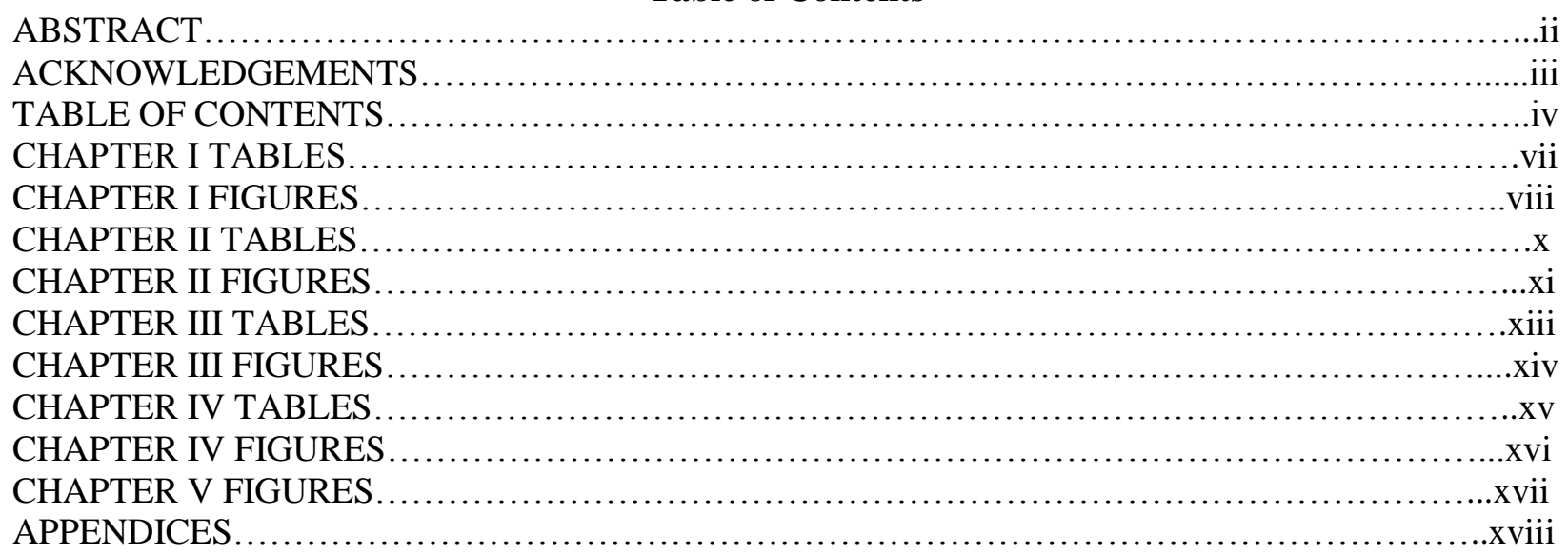

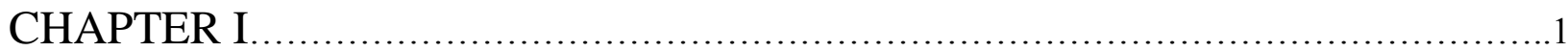

PROJECT OVERVIEW: OBJECTIVES AND LITERATURE REVIEW FOR STREAM

RESTORATION: SITE SELECTION AND PROJECT EVALUATION $\ldots \ldots \ldots \ldots \ldots \ldots \ldots \ldots \ldots \ldots \ldots$

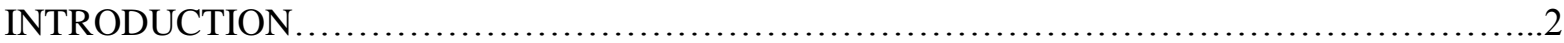

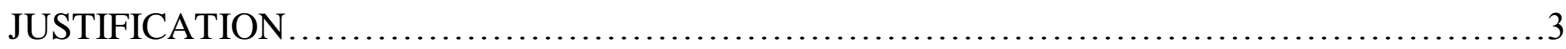

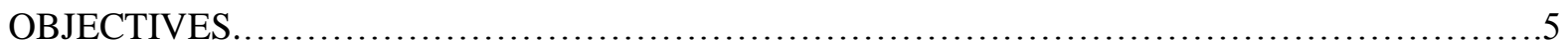

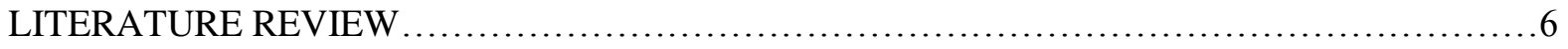

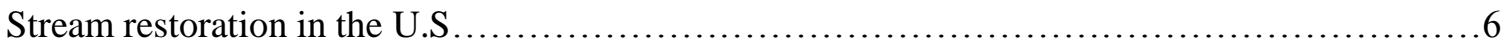

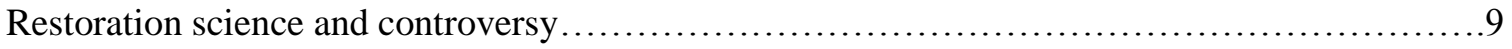

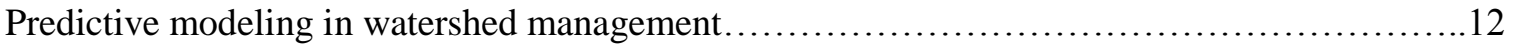

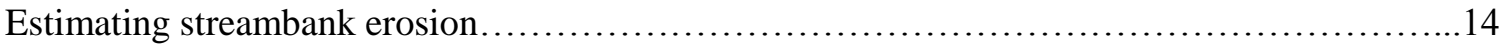

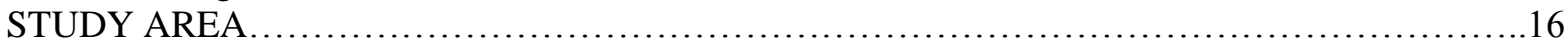

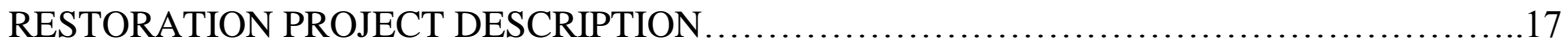

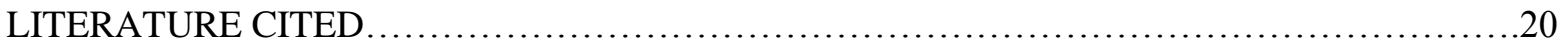

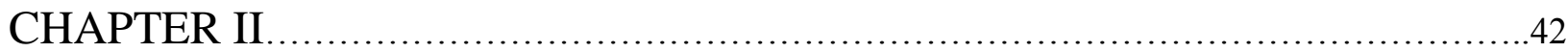

THE PHYSICAL AND ECOLOGICAL EFFECTS OF MULTIFACETED STREAM CHANNEL

RESTORATION IN A CENTRAL APPALACHIAN WATERSHED ..............................42

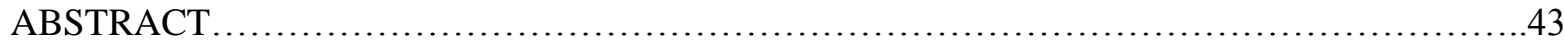

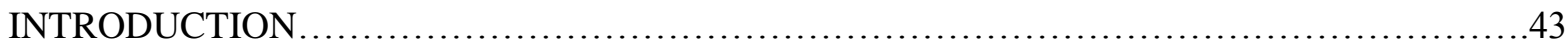

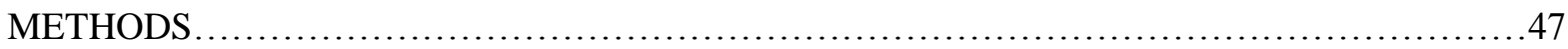

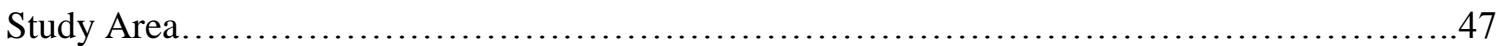

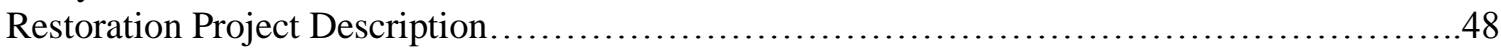

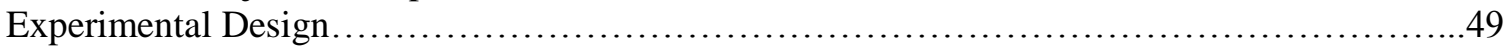

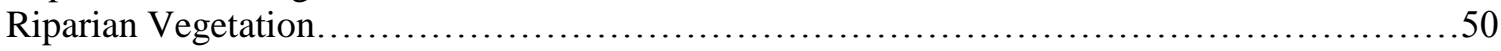

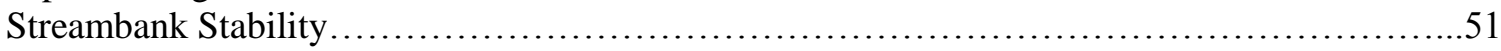

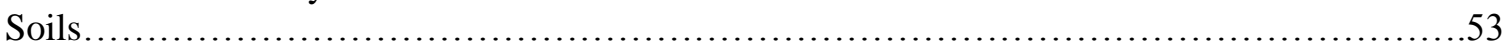

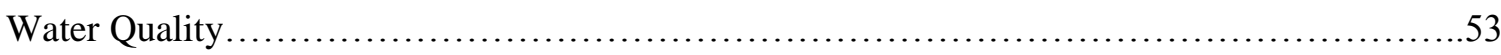

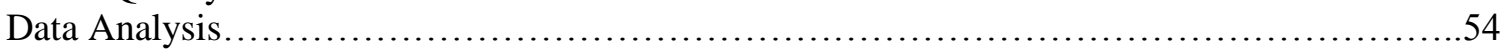

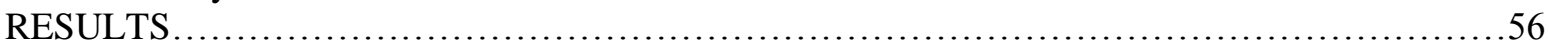

Riparian Vegetation and Streambank Stability ................................................56

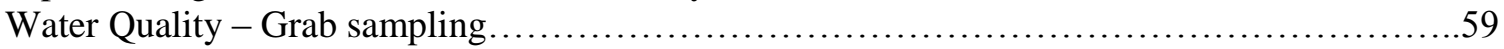

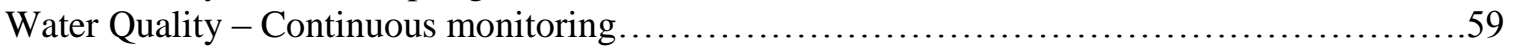

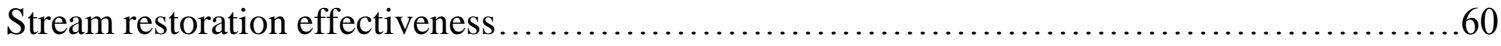

Exploring the influence of local factors on streambank stability ............................62 


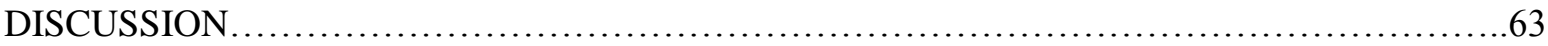

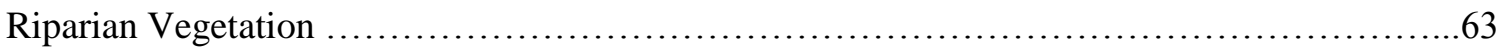

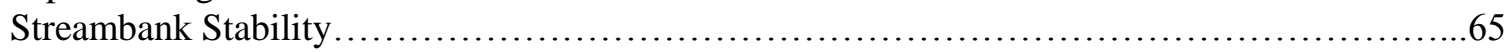

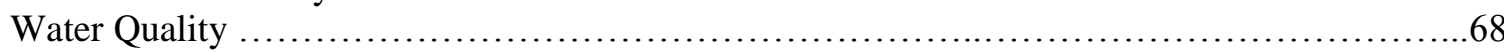

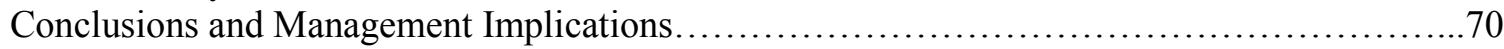

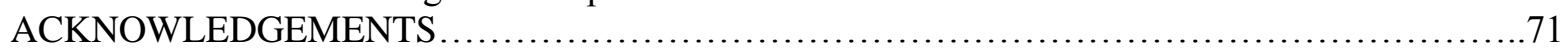

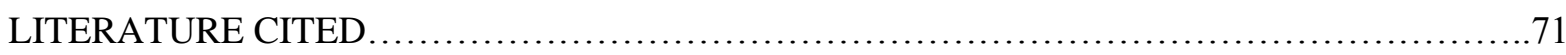

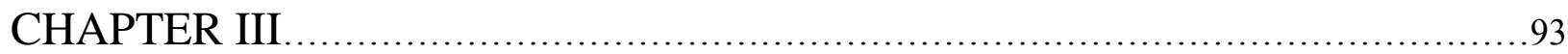

MODELING STREAMBANK EROSION POTENTIAL USING PROBABILITY MODELING IN A

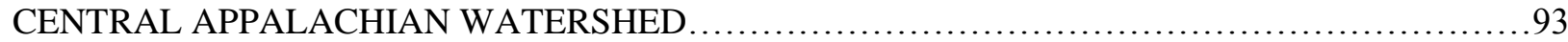

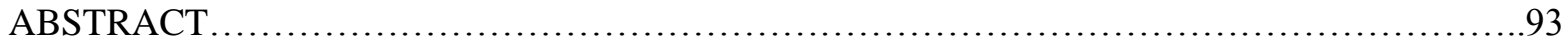

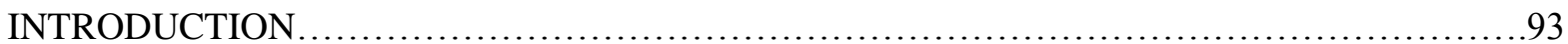

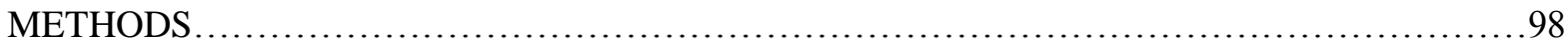

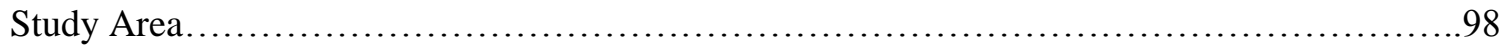

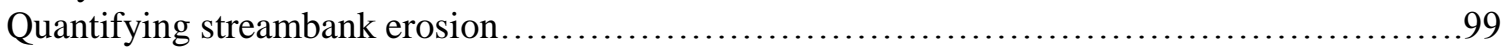

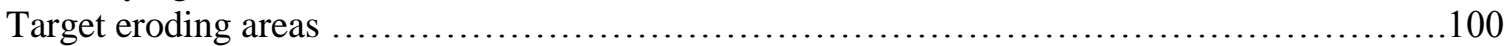

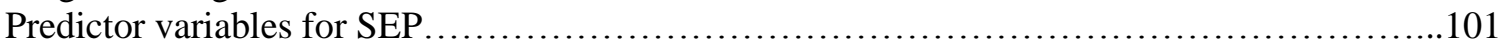

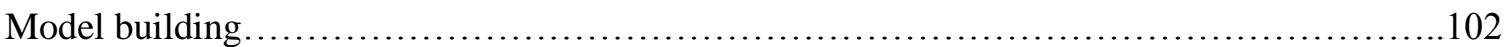

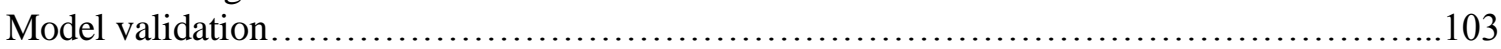

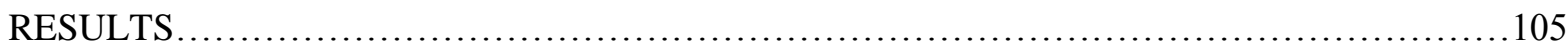

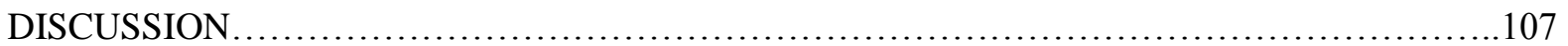

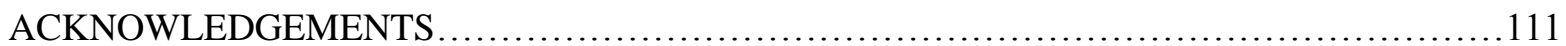

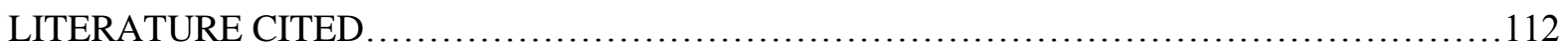

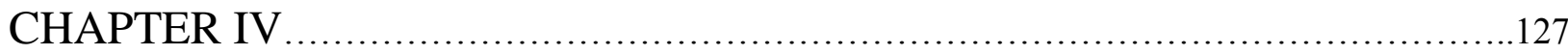

ESTIMATING STREAMBANK MIGRATION AND VOLUMETRIC SEDIMENT LOSS: A

COMPARITIVE STUDY OF TRADITIONAL AND MODERN SURVEY TECHNIQUES ...........127

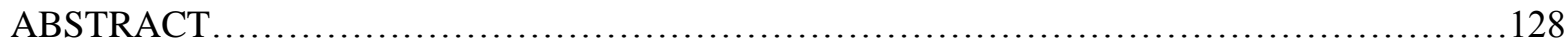

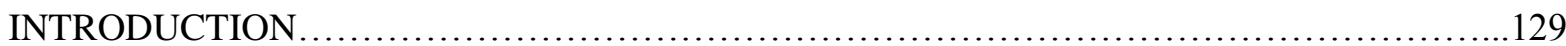

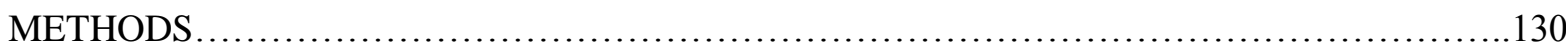

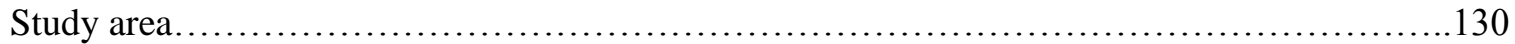

Erosion pin and streambank profile surveys ......................................... 131

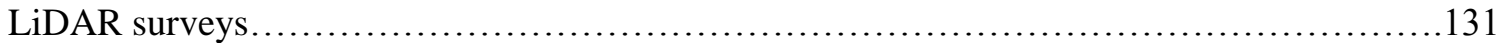

Estimates of streambank migration and volumetric sediment loss ......................... 132

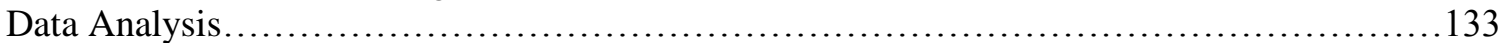

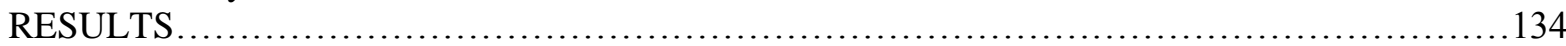

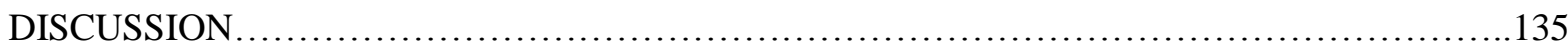

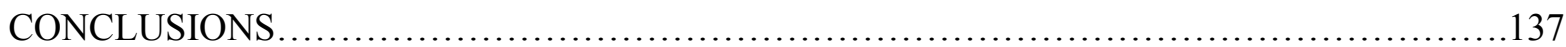

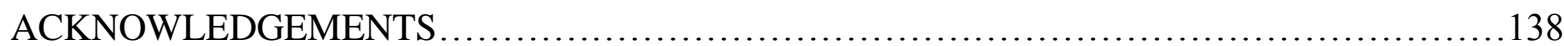

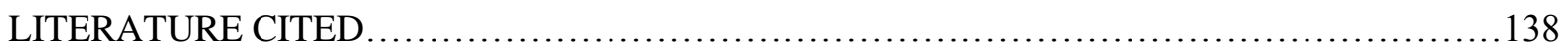

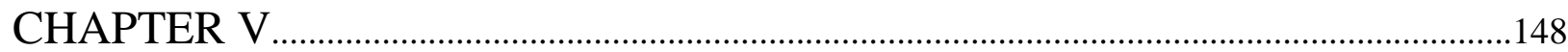

MANAGEMENT IMPLICATIONS FOR STREAM RESTORATION: SITE SELECTION AND

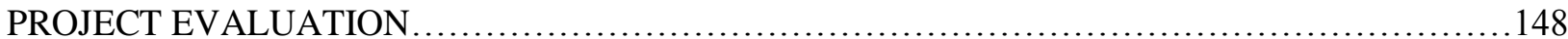

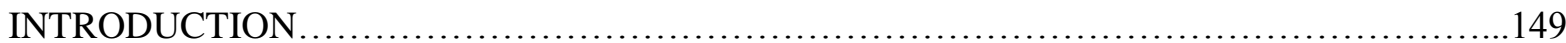

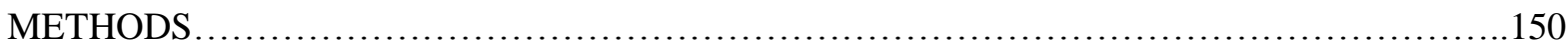

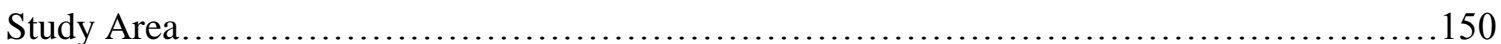

Critical and objective evaluation of a NCD project......................................151

Development of a watershed-scale restoration site selection tool using probability modeling...151 
Evaluation of traditional and modern survey techniques for quantifying streambank stability...151

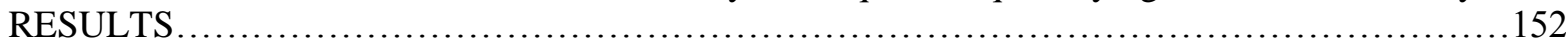

Critical and objective evaluation of a NCD project...................................152

Development of a watershed-scale restoration site selection tool using probability modeling...154

Evaluation of traditional and modern survey techniques for quantifying streambank stability ...154

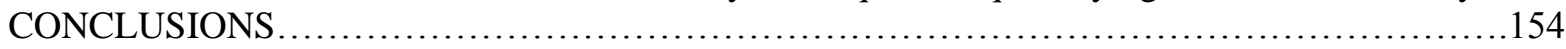

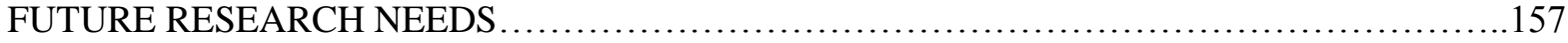

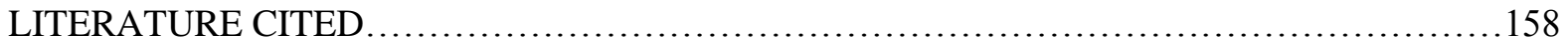




\section{Ch 1: List of tables}

Table 1: Riparian plantings in a restored reach of the Cacapon River, West Virginia. 


\section{Ch 1: List of figures}

Figure 1: Diagram of a cross section of a bankfull bench adapted from Doll et al. (2003) similar to constructed reaches in a 750 meter restored reach of the Cacapon River. The dotted line represents the old channel and the solid line represents the newly constructed channel.

Figure 2: Diagram showing a log vane similar to that constructed on the Cacapon River, West Virginia. Nine log vanes were constructed in the restored reach to reduce bank stress on the toe to prevent fluvial erosion during low flow. The arrows indicate the location of the thalweg.

Figure 3: Cross section diagram of a general planting plan for a two-stage channel used in restoration of a 750 meter reach of the Cacapon River, West Virginia.

Figure 4: Venn diagram from Boleneus et al. (2001) showing the area of highest probability of gold occurrence indicated by the green arrow.

Figure 5: Flood frequency curve generated from peak discharge data from the Cacapon River United States Geological Survey gage 01611500 near Great Cacapon, West Virginia. The curve shows that a flow event of $110 \mathrm{~m}^{3} / \mathrm{s}$ corresponds to the empirically estimated 1.5 year flow, or bankfull event, which is considered to be the dominant discharge among streams in the humid, eastern U.S.

Figure 6: Aerial image with overlays showing location of reconstructed streambanks, in-stream structures, and site names in a reach of the Cacapon River, West Virginia selected for stream restoration.

Figure 7: Photo taken during construction at the restoration site that shows a recently excavated bankfull bench intended to stabilize the streambank by allowing high energy water to expand onto the constructed floodplain depositing sediment and attached forms of nitrogen and phosphorus onto the bankfull bench.

Figure 8: Sequence of photos showing log vane construction at the restoration site designed to reduce shear stress on the streambank. The photo in the center shows how the vane is cabled to a second log under the water, which is also anchored in the bank. Both logs are cabled to a large boulder nearer to the center of the channel. On the upstream side of the vane in the bottom photo are coconut fiber logs, which were installed throughout the reach along reconstructed streambanks to reduce toe erosion.

Figure 9: A sequence of photos taken before (left - June 2009) and after (right - July 2010) stream restoration along a reach of the Cacapon River, West Virginia. Photos show, in descending order, Rest-1 (looking downstream), Rest-2 (looking downstream), Rest-3 (looking upstream), and Rest-4 (looking downstream).

Figure 10: Map showing the location of the Cacapon River Watershed and sites chosen to evaluate the effectiveness of streambank stability treatments. Sites labeled "Rest" are sites that were restored in 2010.

Figure 11: Map showing the location of the Cacapon River Watershed and sites chosen to evaluate the effectiveness of stream restoration on water quality. The photo in the bottom right corner of the map shows grab sampling during the largest flow event occurring during the monitoring period (i.e., $440 \mathrm{~m}^{3} / \mathrm{s}$ ).

Figure 12: Map showing the location of Sondes for continuous monitoring of temperature, $\mathrm{pH}$, conductivity, turbidity, and stream depth upstream and downstream of a restored reach along the Cacapon River, West Virginia. The photo in the bottom right corner of the map shows a Sonde cabled to two cinder blocks and ready for deployment. 
Figure 13: Underlying geology of a portion of the Cacapon River Watershed where LiDAR data were collected for development of a model of streambank erosion potential.

Figure 14: A hillshade map of an area selected for a comparative study of methods used to estimate streambank migration rate. Also shown are the eight survey locations where streambank migration estimates were derived for each method. The hillshade layer was created from airborne LiDAR data collected in April 2010 and will be compared with a second DEM created from ground based LiDAR data collected in November 2011.

Figure 15: The top photo was taken in June 2011 at the upstream end (looking downstream) of a site selected for a comparison of methods for estimating streambank migration rates. The bottom two photos were taken at G-1 in 2010 (left) and 2011 (right). The photo on the left shows a level survey rod on the upstream side of a toe pin, which will be used as a benchmark in subsequent streambank profile surveys to estimate streambank migration rate. Also shown are orange flags indicating the location of five erosion pins (i.e., $1.2 \mathrm{~m} * 1 \mathrm{~cm}$ rebar) hammered into the streambank. The photo on the right shows only one pin remaining at this location in 2011. 


\section{Ch 2: List of tables}

Table 1: Average measures of channel dimension, pattern, and profile in 2009 for a reach of the Cacapon River, West Virginia selected for stream restoration.

Table 2: Cross-section measures from a restored reach of the Cacapon River, West Virginia. $\Delta \mathrm{W} / \mathrm{D}$ is the measured change in width to depth ratio, $|\Delta \mathrm{A} \%|$ is the absolute value of the percent change in stream cross-sectional area, and G diff is the difference in Gini coefficients during the specified time period. Standard error for each variable is shown in parentheses.

Table 3: Estimates of net change in sediment storage derived from repeated streambank profile surveys along a restored reach of the Cacapon River, West Virginia. Standard error for each variable is shown in parentheses. If only one profile survey was conducted due to loss of benchmarks between surveys, no standard error could be calculated.

Table 4: The percentage of nitrogen $(\mathrm{N})$ in soil samples collected from a reach selected for stream restoration on the Cacapon River, West Virginia. Also shown is an estimate of total sediment and $\mathrm{N}$ lost $(-)$ or gained from each site before and $(09-10)$ and after restoration $(10-11)$ using percent $\mathrm{N}$ from soil samples. Standard error for percent $\mathrm{N}$ is shown in parentheses.

Table 5: The percentage of phosphorus $(\mathrm{P})$ in soil samples collected from a reach selected for stream restoration on the Cacapon River, West Virginia. Also shown is an estimate of total sediment and P lost (-) or gained from each site before and $(09-10)$ and after restoration $(10-11)$ using percent $P$ from soil samples. Standard error for percent $\mathrm{P}$ is shown in parentheses. 


\section{Ch 2: List of figures}

Figure 1: Average a) abundance of woody vegetation, b) Shannon-Wiener diversity of woody vegetation $\left(H^{\prime}\right)$, and c) percentage of bare ground in riparian areas along restored sub-reaches compared to a control and reference reach before and after stream restoration in the Cacapon River Watershed, West Virginia. Woody abundance and the percentage of bare ground are shown for all three years of monitoring.

Figure 2: Average a) streambank angle and b) streambank migration rate ( $\mathrm{m} / \mathrm{yr})$ along restored subreaches compared to a control and reference reach before and after stream restoration in the Cacapon River Watershed, West Virginia. Streambank angle is shown for all three years of monitoring.

Figure 3: Photos looking downstream from Rest-4 along a restored reach of the Cacapon River, West Virginia in (a) 2009 before restoration, (b) 2010 after construction of a bankfull bench and log vanes, and (c) 2011 one year after restoration was completed. The proximity of this area to a point bar opposite a rip rap meander bend may have contributed to bank failure as (d) a large portion of the reconstructed streambank washed out in the year following restoration leaving a log vane in the channel following four $1.5-2.5$ year flow events in spring and early summer of 2011 .

Figure 4: Representative cross-sections at each of three streambank sub-reaches along a $750 \mathrm{~m}$ restored reach of the Cacapon River one year before restoration (6/2009), two weeks following restoration (7/2010), and 11 months after restoration (6/2011). Figure a) shows a representative cross section from Rest-1, figure b) from Rest-2/3, and figure c) from Rest-4.

Figure 5: A hydrograph of peak discharge from the Cacapon River near Great Cacapon, West Virginia from June 2009 - July 2011. The approximate start date of restoration activity was 5/10/2010. Based on a calculated bankfull discharge of $110 \mathrm{~m}^{3} / \mathrm{s}$, four distinct bankfull events occurred pre-restoration and postrestoration. The largest magnitude event occurred pre-restoration at $440 \mathrm{~m}^{3} / \mathrm{s}$.

Figure 6: Photos taken of sub-reach Rest-3 in the spring following stream restoration (2011) after floodwaters receded from a) $330 \mathrm{~m}^{3} / \mathrm{s}$ flood event 4/17/2011 - 4/18/2011, b) $245 \mathrm{~m}^{3} / \mathrm{s}$ flood event $4 / 30 / 2011-5 / 1 / 2011$, and c) $355 \mathrm{~m}^{3} / \mathrm{s}$ flood event 5/18/2011 - 5/20/2011 that removed large amounts of sediment and the majority of plantings from the area.

Figure 7: Representative streambank profiles of a) a site within sub-reach Rest-1 in 2009 (one year before restoration) and b) 2010 (immediately preceding restoration). Also shown are profiles from c) a location within sub-reach Rest-3 in 2009 (one year prior to restoration) and d) 2010 (immediately preceding restoration).

Figure 8: Average percentages of clay, silt, and, sand in 2009 at four sub-reaches along a restored reach on the Cacapon River, West Virginia.

Figure 9: Daily average turbidity upstream and downstream of an $750 \mathrm{~m}$ reach of the Cacapon River, West Virginia during a) June 2009 (one year before restoration), b) June 2010 (during the active construction phase), and c) June 2011 (one year after restoration). 
Figure 10: The average difference in upstream and downstream turbidity levels and corresponding \%EPT taxa of macroinvertebrate samples collected from the restored reach before restoration, during construction, and approximately two weeks after construction ended.

Figure 11: Regression tree a) with the lowest cross-validation error (0.81) and b) within one SE of the cross-validation error (0.92) used to explain variation in streambank migration rates $(\mathrm{m} / \mathrm{yr})$ at 44 sites in the Cacapon River Watershed, West Virginia from 2009 - 2010. For a), the first division is the percentage of bare ground (bare) followed by Shannon-Weiner diversity of woody vegetation (woodyS), bank angle (bankangle), and percentage of sand (sand). For b), the percentage of bare ground (bare) was the only variable used for the tree as it explained the majority of variation in migration rates (39\%). Average migration rates and sample sizes are shown below each corresponding terminal branch and the depth of each leaf is related to the percent of variation explained by the dependent variable at each node.

Figure 12: Correlations between the average percentage of bare ground and streambank migration rate for a) all sites without stratification, and b) all sites stratified by the percentage of sand greater or less than 70\% using data collected from 2009-2010 in the Cacapon River Watershed, West Virginia. 


\section{Ch 3: List of tables}

Table 1: Information about environmental variables used to create a model of streambank erosion potential (SEP) in the Cacapon River Watershed, West Virginia including the variable name, source, significance for modeling, geoprocessing steps, minimum values, maximum values, mean, and standard error (SE).

Table 2: Average percent contribution and permutation importance values for each predictor variable in the Maximum entropy distribution of target eroding areas (TEAs) for all 30 replicate model runs.

Table 3: Common thresholds and corresponding descriptions along with average fractional predicted area and omission rates for ten replicate runs of a Maximum entropy model of streambank erosion potential (SEP). 


\section{Ch 3: List of figures}

Figure 1: A portion of the Cacapon River Watershed, West Virginia where airborne LiDAR was flown for development of a maximum entropy model of streambank erosion potential (SEP). Also shown are 29 target eroding areas (TEAs) for streambank erosion identified from 151 sites within the study area where streambank erosion rates were measured in 2010 - 2011.

Figure 2: Threshold independent receiver operating characteristic curve (ROC) for Maximum entropy representing one of 30 random partitions of occurrence records of target eroding areas (TEAs) generated using nine predictor variables. Sensitivity $(1$ - omission) is the proportion of presence records correctly predicted by the model and 1 - specificity is the proportion of the pixels in the study extent predicted to be TEAs. The average area under curve (AUC) for all model runs was 0.994 ( $\mathrm{SE}=0.0005)$ indicating excellent model performance. Average test AUC for all model runs was 0.985 ( $\mathrm{SE}=0.002$ ).

Figure 3: The influence of a) slope $\left(^{\circ}\right)$, b) bank stress index, c) soil type, and d) underlying geology on the logistic output (probability of presence) of a target eroding areas (TEAs). Each response curve shows the relation between each variable and the logistic probability of presence of a TEA when all other variables are held at their mean.

Figure 4: Results of jackknife analyses from 30 replicate maximum entropy model runs of target eroding areas (TEAs). These results show the relative importance of each variable when all other variables held at their mean and when used alone with respect to a) training gain, b) test gain, and c) Area Under Curve (AUC) values. Fluctuations in training and test gain represent changes to the coefficients that occur in each step of the maximum entropy algorithm in response to the addition or exclusion of environmental variables.

Figure 5: Logistic output of a maximum entropy model of streambank erosion potential (SEP) reclassified to represent five levels of SEP in a portion of the Cacapon River Watershed, West Virginia. Areas in the blue are below the minimum training presence $(\mathrm{MTP}=0.209)$ of target eroding areas (TEAs). The other two levels of SEP represent equal intervals of logistic model output greater than the MTP.

Figure 6: Streambank erosion potential (SEP) ratings (low, moderate, and high) and corresponding mean migration rates for 151 sites where streambank erosion rates were monitored for $2010-2011$. An Analysis of Variance (ANOVA) on the classification scheme derived from Maxent logistic output on 151 sites monitored in the Cacapon River Watershed, West Virginia revealed that the Maximum entropy classification could distinguish between sites with low (a) versus moderate or high SEP (b). 


\section{Ch 4: List of tables}

Table 1: Estimates of streambank migration derived from repeated erosion pin, streambank profile, and LiDAR surveys along a reach of the Cacapon River, West Virginia. Sites with "lost" represent those sites where erosion pins or toe pins used as benchmarks for repeated profiles were lost between surveys.

Positive values represent degradation and negative values represent aggradation. 


\section{Ch 4: List of figures}

Figure 1: Survey sites at a site along a reach of the Cacapon River in the Cacapon River Watershed in the eastern panhandle of West Virginia, USA used in a comparative study of survey methods for estimating streambank migration and volumetric sediment loss.

Figure 2: Equipment used to conduct streambank profile surveys along a reach of the Cacapon River, West Virginia, USA showing a) a leveled survey rod anchored to a tripod, where a laser distance measurer was used to collect streambank migration data for creation of b) a streambank profile for 2010 and 2011. The white arrow in the photo is pointing to an erosion pin which was also used to derive an estimate of streambank migration, and for a reference point in the streambank profile survey.

Figure 3: Streambank profile interpolated from airborne LiDAR data collected in 2010 along a reach of the Cacapon River, West Virginia, USA. The profile was generated using 3D Analyst tools in ESRI® $\operatorname{ArcMap}^{\mathrm{TM}} 10.0$ at the location designated by the arrow in the image on the right.

Figure 4: Estimates of streambank migration derived from repeated erosion pin, streambank profile, and LiDAR surveys for a 235 meter reach along the Cacapon River, West Virginia, USA. An Analysis of Variance (ANOVA) on migration showed that estimates derived from erosion pins and streambank profile surveys (a) were different from estimates derived from repeated LiDAR surveys (b). Average values corresponding to "pins-1" were calculated by excluding erosion pins that were lost between surveys. Average values corresponding to "pins-2" were calculated by assigning a value of 0.61 to lost erosion pins.

Figure 5: Estimates of volumetric soil loss using repeated erosion pin, streambank profile, and LiDAR surveys for a 235 meter reach along the Cacapon River, West Virginia, USA. Values for "pins-1" were calculated by excluding erosion pins that were lost between surveys

Figure 6: Volumetric change estimated from repeated LiDAR surveys along a $235 \mathrm{~m}$ reach of the Cacapon River, West Virginia, USA. Pixels shaded blue represent areas where a net gain in sediment occurred between surveys, red pixels represent areas where net sediment loss occurred, and yellow pixels represent areas where no change occurred.

Figure 7: Scan angle of a) airborne LiDAR surveys (ALS) and terrestrial LiDAR surveys (TLS) result in differences in interpolated surfaces as evidenced by streambank profiles derived from b) ALS and TLS along a reach of the Cacapon River, West Virginia, USA. Note the higher point densities for TLS, which was able to more accurately represent undercut portions of the bank face.

Figure 8: Volumetric change estimated from repeated LiDAR surveys along a $235 \mathrm{~m}$ reach of the Cacapon River, West Virginia, USA symbolized to show variation in sediment loss along the reach. Pixels shaded with cool colors represent areas where sediment gain occurred between surveys, and warm colors represent areas where sediment loss occurred. Neutral colors have values near zero where little change occurred. 


\section{Ch 5: List of figures}

Figure 1: Photos showing different responses to stream restoration within a restored reach of the Cacapon River, West Virginia from 2009 (left) - 2011 (right). Restoration was considered successful at one subreach as streambank stability increased (i.e., soil loss decreased) from a) 2009 to b) 2011; however, efforts were considered unsuccessful at another sub-reach where soil loss increased from c) 2009 to d) 2011.

Figure 2: Photos from four reaches in the Cacapon River Watershed, West Virginia where target eroding areas (TEAs) were detected based on erosion rates measured from $2010-2011$. TEAs were used as training sites to develop a model of streambank erosion potential (SEP) over the study extent.

Figure 3: Photo showing a terrestrial LiDAR scanner used to create a three dimensional model of the streambank across the river. Scanner position allowed for better scan angles for capturing feautres such as undercut banks compared to airborne LiDAR scans, and high point densities of terrestrial scans can be used to produce accurate, high resolution data sets from which streambank migration and volumetric sediment loss can be estimated. 


\section{List of appendices \\ Ch 1 appendices}

Appendix Ia. Bank erosion hazard index (BEHI) used to select sites used to evaluate the effects of stream restoration in the Cacapon River, West Virginia. 


\section{Ch 2 appendices}

Appendix IIa. Diagram of a cross-section of a bankfull bench adapted from Doll and others (2003). The dotted line represents the old channel and the solid line represents the newly constructed channel. This is the general design used for priority three natural stream channel restoration, and was most similar to the approach used along a restored reach of the Cacapon River, West Virgnia.

Appendix IIb. Aerial image with overlays showing location of reconstructed streambanks, in-stream structures, and site names in a reach of the Cacapon River, West Virginia selected for stream restoration.

Appendix IIc. Map showing the location of sites chosen for assessing the effectiveness of stream restoration on improving riparian integrity and streambank stability.

Appendix IId. Map showing the location of the Cacapon River Watershed and sites chosen to evaluate the effectiveness of stream restoration on water quality.

Appendix IIe. Map showing the location of Sondes for continuous monitoring of temperature, $\mathrm{pH}$, conductivity, turbidity, and stream depth upstream and downstream of a restored reach along the Cacapon River, West Virginia. The photo in the bottom right corner of the map shows a Sonde cabled to two cinder blocks, ready for deployment.

Appendix IIf. Map showing the location of the Cacapon River Watershed and sites chosen to evaluate the influence of riparian characteristics and soil composition on streambank migration rate.

Appendix IIg. An example of a $25 \times 20$ meter quadrat used to evaluate the effects of restoration on riparian integrity on the Cacapon River, West Virginia. Each plot was centered on benchmarks established in the lower bank area used for streambank profile surveys. Woody vegetation within the larger quadrat (i.e., $25 \times 20$ m quadrat) was counted to species. Herbaceous vegetation was quantified within five evenly spaced $1 \times 1$ meter sub-plots along the top and toe of the bank using a cover class method to describe percent cover for each species and the percentage of bare ground.

Appendix IIh. Average Shannon-Wiener diversity of the herbaceous community in riparian areas along restored sub-reaches compared to a control and reference reach before (2009), immediately after (2010), and one year after (2011) stream restoration in the Cacapon River Watershed, West Virginia. Appendix IIi. Average concentration of nitrates $\left(\mathrm{NO}_{3}\right)$ before $(6 / 2009-4 / 2010)$ and after $(6 / 2010-$ 12/2011) stream restoration along a reach of the Cacapon River, West Virginia compared to a control and reference reach.

Appendix IIj. Average concentration of ammonia $\left(\mathrm{NH}_{3}\right)$ before $(6 / 2009-4 / 2010)$ and after $(6 / 2010-$ 12/2011) stream restoration along a reach of the Cacapon River, West Virginia compared to a control and reference reach.

Appendix IIk. Average concentration of total phosphorus (P) before (6/2009 - 4/2010) and after (6/2010 12/2011) stream restoration along a reach of the Cacapon River, West Virginia compared to a control and reference reach. 
Appendix IIl. Average concentration of total suspended solids (TSS) before (6/2009 - 4/2010) and after $(6 / 2010$ - 12/2011) stream restoration along a reach of the Cacapon River, West Virginia compared to a control and reference reach. 


\section{Ch 3 Appendices}

Appendix A1. Pfankuch stream reach inventory and channel stability evaluation used to locate areas in fair or poor condition in the Cacapon River Watershed, West Virginia where erosion rates were measured from $2010-2011$ in development of a model of streambank erosion potential (SEP). 


\title{
CHAPTER I
}

PROJECT OVERVIEW: OBJECTIVES AND LITERATURE REVIEW FOR STREAM RESTORATION: SITE SELECTION AND PROJECT EVALUATION

\author{
Jonathan L. Pitchford \\ jpitchford@imms.org \\ West Virginia University \\ Division of Forestry and Natural Resources \\ PO Box 6125 \\ Morgantown, WV 26506
}




\section{Introduction}

Over 170,000 river kilometers in the United States are estimated to be negatively affected by sediment pollution, which is second only to pathogens as the top ecological stressor of freshwater resources in the U.S. (U.S. EPA 2011). The link between sediment pollution and decreased ecological health has been firmly established over the last century through several pathways including inhibition of primary production, increases in attached constituents of phosphorus and nitrogen, and disruption of reproduction for aquatic species that require clean spawning gravels (Waters 1995). The two most commonly implicated sources of sediment to freshwater streams are overland flow and streambank erosion, which are natural processes that promote healthy ecosystems; however, timber harvesting, road construction, urban development, and agriculture have been linked to excessive increases in sedimentation, which have negatively impacted aquatic ecosystems in many areas (Waters 1995). Recently, more attention has been paid to sediment production via streambank erosion, which can contribute as much as $80 \%$ of the sediment load in some streams (Simon and Thorne 1996).

Increased awareness of stream degradation has spurred much interest in stream reclamation, rehabilitation, and restoration (all of these terms will all be collectively referred to as restoration throughout this document) that seek to improve the conditions of a given stream to a pre-disturbance or more fully functional state via human intervention (Downs et al. 2002). Complicating the issue of stream restoration is that of complexity of both stream systems and the societal and political factions that govern them. Streams are vital to humans as a functional resource on many levels, and historically humans have found many ways to manipulate streams to garner desired resources (e.g., water, power, etc.). In recent years, many have begun to realize that human demand and manipulation of these resources can have many negative, long-term effects that are not sustainable. Unfortunately, the ability to undo the damage that has been done to streams has not reached optimal levels, and we are therefore, still on the learning curve regarding our understanding of streams and how to effectively restore them (Kondolf and Micheli 1995; Kondolf 1998; Kondolf et al. 2001; Smith and Prestegaard 2005; Wohl et al. 2005). Much of this difficulty stems from the complexity of stream systems and the multidisciplinary nature of truly effective 
solutions for stream restoration. The information presented in this document draws from several scientific disciplines at the core of stream restoration, and can hopefully be a small step up the learning curve to achieving healthier, more sustainable aquatic ecosystems.

\section{Justification}

Stream restoration is in its infancy. Many restoration practitioners assume their activities will produce the desired results; however, projects are rarely assessed to determine if they are effective (Bash and Ryan 2002; Hasset et al. 2005). Given unprecedented increases in restoration projects and in resource allocation to restoration (Kondolf and Micheli 1995; Bash and Ryan 2002; Bernhardt et al. 2005; Palmer and Bernhardt 2006), it is imperative that monitoring and hypothesis driven research follow suit (Wohl et al. 2005). This is the only way to improve a young field sated with uncertainty, so much uncertainty that a currently relevant research question is: "Is stream restoration effective?" To answer this question, one only needs to define a variable of interest and measure it before and after restoration. For example, if bank stabilization is a desired project outcome, measurement of streambank migration rates before the project begins and then again after its conclusion should provide conclusive evidence. Reports like Gerstein and Harris (2005) provide an excellent framework for evaluating bank stabilization in this manner where several pertinent response variables, methods of measurement, and analysis approaches are suggested. The small number of published studies relative to the large number of ongoing restoration projects indicates that many are under the assumption that restoration is effective, but a close look at the literature reveals that many critically evaluated projects fail to meet expectations (Kondolf and Micheli 1995; Kondolf 1998; Kondolf et al. 2001; Smith and Prestegaard 2005). This makes answering basic questions about project effectiveness foundational in restoration science.

"Where" stream restoration is attempted of utmost importance. A growing number of restoration scientists agree that where we are doing restoration and the scale at which the project is implemented is a very important component of effective restoration (Kondolf and Micheli 1995; Roni et al. 2002; Palmer et al. 2003; Wohl et al. 2005). Emphasis is commonly placed on what stream restoration approach is needed 
at a site and how to accomplish it, and less time is spent on site selection, which is typically constrained by access and cooperating landowners. A call for decision support tools that incorporate geographic information systems (GIS) and probability models have been suggested by some to remove some of the subjectivity out of the site selection process and incorporate quantitative methods for designing comprehensive, watershed scale restoration plans (Wohl et al. 2005; Strager et al. 2011). The limited success of reach-scale projects is one of the most heavily criticized limitations of current stream restoration practices; however, site prioritization tools will allow reach-scale projects to be part of watershed restoration plans, which will facilitate improved management success. Additionally, process models that incorporate GIS and probability modeling can provide information about the conditions that are associated with stable and unstable sites within the context of the watershed (Wohl et al. 2005), which will aid in selecting sites with the greatest restoration potential and in development of an effective design approach.

Methods for measuring streambank migration have varying levels of precision, accuracy, and cost-effectiveness. Syntheses of restoration projects in the U.S. have shown that few projects are monitored before and after implementation to determine effectiveness, and have implicated a lack of resources as the primary cause for this deficiency (Bash and Ryan 2002; Hasset et al. 2005). Careful review of current methods for measuring the physical response of a reach to restoration often suggest cross section surveys as the primary method for assessment (Kondolf and Micheli 1995; Gerstein and Harris 2005); however, several lesser known methods exist for quantifying streambank stability that vary greatly with regard to resources available for monitoring. Scientific review and comparisons of the strengths and weaknesses of these methods should help restoration practitioners and researchers select an appropriate method that will produce the highest quality data available given resource constraints. 


\section{Objectives}

I hypothesize that reach-scale stream restoration project improves riparian integrity, increase streambank stability, and reduce in-stream concentrations of problem pollutants.

The objectives used to address this hypothesis are:

1. Compare riparian community composition, streambank migration rates, and in-stream concentrations of total phosphorus $(\mathrm{P})$, ammonia (NH3), nitrates (NO3), total suspended solids (TSS), and turbidity before and after implementation of a stream restoration project in the Cacapon River Watershed, West Virginia.

I hypothesize that streambank erosion potential can be accurately modeled at the watershed-scale using probability modeling and remotely sensed parameters commonly associated with streambank erosion. The objectives I will use to address this hypothesis are:

1. Measure streambank migration rates throughout the Cacapon River watershed from 2010 - 2011 and use a quantitative approach to find target eroding areas for management.

2. Define and create a set of remotely sensed predictor layers that are commonly associated with streambank erosion.

3. Use a maximum entropy modeling approach incorporated in a GIS to predict streambank erosion potential (SEP) for a portion of the Cacapon River Watershed.

4. Test the strength of a SEP classification system derived from maximum entropy model output using erosion rates measured in the field.

5. Compare estimates of streambank migration and volumetric sediment loss calculated from repeated erosion pin, streambank profile, and LiDAR surveys. 


\section{Literature Review}

Stream restoration in the U.S.

Stream restoration is currently a multibillion dollar industry in the U.S. in spite of great controversy regarding its implementation and effectiveness. Much of this controversy stems from the privatization of stream restoration and ensuing debates between academically trained fluvial geomorphologists and private restoration firms, which often disagree on core issues related to restoration such as: when is restoration warranted, what approaches should be used to restore degraded systems, and how restored systems should be evaluated (Kondolf 1995; Wohl et al. 2005; Lave et al. 2010). Although both camps have their own answers for these questions and have garnered large numbers of supporters, the fact remains that stream restoration is a young field abounding with uncertainty (Kondolf 1996; Palmer et al. 2003; Wohl et al. 2005). Thus, each stream restoration project is, to some degree, an experiment with a tailored design approach given site conditions and project goals (Kondolf 1998). Although biological components are often deemed endpoints of restoration efforts, successful restoration of key physical and chemical parameters are foundational for increased ecological integrity, yet are rarely assessed before and after restoration to determine project effectiveness (Bernhardt et al. 2005; Kondolf 1996).

The Army of Corps of Engineers were the primary agents of stream manipulation in the U.S. prior to 1990, and have been responsible for thousands of projects throughout the country including dam and levee construction, stream channelization, and stream stabilization. Until recent decades the primary means of stream stabilization involved installation of concrete trapezoidal channels, concrete weirs, riprap channels, and gabion baskets (Kondolf 1996). However, in the late 1980s Dave Rosgen, a former employee of the U.S. Forest Service developed an alternative approach to stream stabilization called Natural Channel Design (NCD). Natural Channel Design is best known for its natural approach to restoration where channel dimensions of a "reference reach" within the same watershed are reconstructed in the impaired reach and strategically placed natural materials (e.g., log vanes, root wads) are used to 
promote ecological recovery. The Rosgen classification system is also an important component of NCD, where dimensionless ratios are used to classify stream reaches, indicate the degree of impairment, and elucidate restoration strategies that will be successful at the impaired reach based on an evolutionary tendency of rivers to follow a predictable sequence of stream types following a disturbance (Doll et al. 2003). The introduction of NCD was timely given unprecedented increases in public interest for environmental restoration and "natural" solutions. Since that time, exponential increases in stream restoration projects have occurred throughout the U.S. with NCD becoming the primary stream restoration approach endorsed by the federal agencies such as the Environmental Protection Agency, U.S. Fish and Wildlife Service, Natural Resources Conservation Service, and the U.S. Forest Service. However, critical evaluation of projects that employ NCD have not followed suit with project evaluation rarely being a requirement of restoration projects (Kondolf 1996; Bash and Ryan 2002; Wohl et al. 2005; Palmer and Bernhardt 2006).

Stream restoration design using NCD hinges on theoretical concepts such as bankfull discharge, originally developed by Gordon Wolman and John Miller in 1960. The Wolman-Miller Hypothesis states that the majority of a river's sediment load is transported during moderate flow events that occur, on average, every one to two years (Wolman and Miller 1960). As such, relatively frequent events of moderate magnitude corresponding to bankfull discharge are responsible for maintaining channel form. NCD is heavily reliant on correct identification of bankfull stage, which is the foundation of project design using this method (Rosgen 1996). In some cases, attempts at streambank stabilization are made by constructing a bankfull bench, which involves re-contouring vertical streambanks to create a two-stage channel (i.e., NCD priority three restoration - Figure 1) that has two major functions 1) to more easily accommodate flood flows while retaining a narrower low flow channel, and 2) to allow stabilizing riparian vegetation to more easily establish (Kondolf 1996; Doll et al. 2003). In theory, creation of a twostage channel will also enhance wildlife and aquatic habitat and improve water quality by increasing the density and integrity of riparian vegetation and by improving floodplain connectivity. This makes the two-stage channel an attractive approach for managers concerned with multiple project outcomes; 
however, critical evaluation of this technique is often lacking especially considering the relative newness of this approach.

Several other stream restoration techniques have become quite popular since the inception of NCD including construction of in-stream structures from natural materials to alter local hydrologic conditions. Log vanes, for example, reduce local bank stress and decrease toe erosion circumventing translational and cantilever streambank failure (Figure 2) (Rosgen 1996; Doll et al. 2003; Langendoen and Simon 2008). Riparian plantings can serve a similar function by increasing bank resistance to erosive shear forces via increased roughness along the streambank, which aids in energy dissipation, and by increasing tensile strength of the soil matrix (Figure 3 - Zone A) (Hey 2006; Simon et al. 2007; Simon et al. 2008). Plantings above the top of bank (Figure 3 - Zone B) also provide stability via root reinforcement and function as a filtration system for runoff from adjacent areas. Multifaceted stream restoration approaches that employ a combination of morphological reconstruction, in-stream structures, and riparian planting will likely be more successful than sole measures of bank stabilization and are believed to be more successful at achieving goals of increased water and habitat quality (Downs et al. 2002).

Regardless of the restoration techniques employed at a given site, the importance of monitoring cannot be overstated (Kondolf 1996; Bash and Ryan 2002; Wohl et al. 2005; Palmer and Bernhardt 2006). Stream restoration in the Chesapeake Bay watershed typically has three primary goals: riparian management, water quality management, and streambank stabilization, yet only $5.4 \%$ have conducted basic before and after surveys to determine project effectiveness (Hasset et al. 2005). Of the projects within the Chesapeake Bay watershed that did monitor project effectiveness, only $24 \%$ assessed the response of the physical structure of the restored reach over time. These statistics are startling considering exponential increases in project implementation (Hasset et al. 2005; Lave et al. 2010), but are not surprising in light of multiple barriers to monitoring such as lack of funding, time, and personnel (Bash and Ryan 2002). Restoration techniques that employ highly interventionist approaches such as morphological reconstruction (e.g., two-stage channel construction) and installation of in-stream 
structures must be critically evaluated with regard to the physical response of the restored system. Future success of stream restoration relies on such evaluations to determine what works, what does not, and to provide potential explanations for project success or failure. Without a greater emphasis on project evaluation, stream restoration efforts may ultimately be a waste of public funds.

Methods for monitoring project success have been proposed in the literature (Harrelson et al. 1994; Kondolf and Micheli 1995; Bash and Ryan 2002; Palmer et al. 2003; Gerstein and Harris 2005), but distilling these methods into a feasible monitoring strategy may be difficult because of the large number of responses that may be affected by restoration. Research that incorporates statistical analysis of monitoring results can be even more difficult because of constraints inherent to most restoration projects such as small sample size, lack of independence, and difficulty locating and accessing appropriate control sites (Kondolf and Micheli 1995; Gerstein and Harris 2005). Monitoring the Effectiveness of Bank Stabilization Restoration is a useful guide for bank stabilization projects that highlights key response variables that should be monitored and provides guidelines on experimental design that accounts for common constraints of restoration research (Gerstein and Harris 2005). The before-after-control-impact (BACI) design is endorsed in this document as a valuable tool for statistical evaluation. When using the BACI design, researchers monitor response variables before and after restoration at the restored location and at one or more control areas to account for natural variability in the response, thereby increasing the power to detect treatment effects (Smith et al. 2002).

\section{Restoration science and controversy}

One way restoration scientists are seeking answers to questions about the effectiveness of restoration is through the National River Restoration Science Synthesis (NRRSS), which was developed to improve communication between restoration practitioners and researchers. NRRSS is an online database that includes site location information, project goals, restoration approaches, and any obtainable information about project effectiveness of thousands of restoration projects throughout the U.S. over the last few years (Bernhardt et al. 2005). Other more traditional efforts to improve our ability to do effective 
restoration are through case studies and reviews of stream restoration projects (Kondolf 1996; Kondolf 1998; Kondolf et al. 2001; Price and Birge 2005; Smith and Prestegaard 2005; Bukaveckas 2007; Craig et al. 2008; Selego et al. 2012). Many physical, chemical, and ecological responses to restoration are documented in these studies, and most attempt to elucidate shortcomings in restoration approaches and provide explanations for project success or failure (Kondolf 1996; Kondolf 1998; Kondolf et al. 2001; Smith and Prestegaard 2005). In this manner, a small number of case studies play a vital role for increasing understanding of restoration and thus improving success rates of future projects.

The effects of stream restoration on water quality and ecological health have been studied in greater detail in the last decade (Laasonen et al. 1998; Bednarek 2001; Roni et al. 2002; Lepori et al. 2005; Price and Birge 2005; Bukaveckas 2007; Craig et al. 2008; Selego et al. 2012). Improvements in rates of nutrient uptake and sediment storage resulting from restoration activities have been documented in several studies where project goals such as nitrogen removal rates were clearly defined and the restoration approach was aimed specifically at achieving those goals by decreasing water velocity, increasing transient storage time, increasing availability of in-stream carbon, and increasing floodplain connectivity (Bukaveckas 2007; Craig et al. 2008). Such approaches to restoration are not reliant on a single design approach like NCD, but instead are collaborative, multidisciplinary efforts with tailored design approaches imposed at segment or watershed scales. Improvements in ecological health have also been documented in projects that successfully increased longitudinal connectivity, removed stressors, or enhanced habitat. Dam removal projects have been successful at improving fisheries in many parts of the U.S. by improving longitudinal connectivity, which is vital for reproduction of many fish species (Bednarek 2001; Roni et al. 2002). The jury is still out on projects aimed at improving ecological health via reach-scale restoration. Some studies have shown ecological improvement resulting from reach-scale improvements such as construction of in-stream structures that increase habitat heterogeneity (Laasonen et al. 1998; Selego et al. 2012), while others have found that restoration had little to no effect on aquatic communities (Laasonen et al. 1998; Price and Birge 2005; Lepori et al. 2005; Cooperman et al. 2007). Conflicting results indicate other factors, possibly operating at scales larger than the restored reach, may 
be influencing aquatic community response, and that short-term monitoring of in-stream biota is not accurately capturing ecological response to restoration (Laasonen et al. 1998; Cooperman et al. 2007).

Channel reconstruction projects that have been critically reviewed by fluvial geomorphologists have gone into great detail to explain a lack of success in restoration efforts (Kondolf 1996; Kondolf 1998; Kondolf et al. 2001; Smith and Prestegaard 2005). Neglected hydraulic considerations are often the subject of scrutiny in these studies. For example, Uvas Creek, California, a historically braided stream, was reconstructed to a meandering, single thread channel. The restored reach completely washed out and naturally converted back to the original braided form after a flood with a return interval of $5-6$ years. A case study of the project suggested that reliance on a single bankfull discharge in project design and use of channel stability as a restoration endpoint as potential reasons for project failure (Kondolf et al. 2001). Another failed project in Deep Run, Maryland was similarly criticized for imposition of a new channel form that could not be supported given local hydraulic conditions. At Deep Run, vegetation removal resulting in reductions in floodplain roughness and modifications to flow path sinuosity allowed flow events smaller than the designed bankfull discharge to wash out reconstructed portions of the channel (Smith and Prestegaard 2005). An overarching theme of these studies is that NCD is over-interventionist, oversimplified, and should not be promoted by governmental agencies and private contractors as a primary method for effective stream restoration (Lave et al. 2010).

The debate between restoration science and practice, also called the "Rosgen Wars," is highly charged with politics and personal agendas that can hinder objectivity and cloud pure scientific debate. A debate that spilled over into the scientific literature showcased conflicting professional opinions regarding the effectiveness of NCD and adoption of this approach by governmental agencies (Simon et al. 2007). The authors' major purpose was to provide examples to discredit the use of NCD and the form based classification system upon which it hinges, and to propose quantification and modeling of channel processes as the primary diagnostic tool for restoration practitioners. A retort by Rosgen the following year defended NCD claiming that without proper training, misdiagnosis and misapplication of the form based classification system will occur. Rosgen rebutted every critique in the initial publication (i.e., 
Simon et al. 2007) in great detail and provided regression analyses to show strong relations between channel form and process (Rosgen 2008). The NCD critics followed with a second publication that initially jabs at Rosgen's inattention to the peer review process and then lands several, peer reviewed blows to NCD regarding the importance of bank material composition for predicting stability and negligence of this fact by Rosgen and his followers (Simon et al. 2008). Rosgen continues to support NCD through non-peer reviewed publications such as conference proceedings and through articles published by his company, Wildland Hydrology. He uses these venues to speak to failed projects (Kondolf et al. 2001; Smith and Prestegaard 2005) often highlighting misuse of the approach by practitioners who lack the experience and training necessary to effectively implement NCD techniques (Rosgen 2006). It seems clear that from a scientific standpoint, the crux of this debate centers on form versus process as a means for diagnosis and treatment of the ailing system (Doyle et al. 1999; Simon et al. 2007, 2008) and experience versus inexperience in the application of NCD (Rosgen 2008, Rosgen 2006), which has received endorsements from academically trained geomorphologists (Hey 2006). Both sides of the debate would likely agree that the inherent complexity of stream systems and the steep learning curve to effectively restore degraded systems make restoration difficult regardless of the methods employed, and most would agree that these issues are further complicated by privatization of stream restoration reflecting the needs of regulatory agencies to standardize restoration training and practice (Lave et al. 2010).

Predictive modeling in watershed management

In 1972, the Clean Water Act (CWA) set the stage for increased regulation and awareness of water quality impairment in the U.S., and has resulted in drastic improvements in wastewater treatment and river management over the last several decades (Houck 2002). Recently, as efforts to actively restore degraded watersheds has grown, a niche has been created for assessment tools and models that enable resource managers to make informed decisions with regard to where management efforts should be focused and the approaches needed to achieve management goals (Russel et al. 1997; Rosgen 2001; 
Vitalis and Manoliadis 2002; Evans et al. 2003; Goetz 2006; Strager and Rosenberger 2006; Strager et al. 2011). Many of these tools incorporate remote sensing and geographic information systems (GIS), which allow large areas to be assessed without the need for extensive field surveys (Evans et al. 2003; Strager et al. 2011).

A variety of assessment tools and models have been developed in the last few decades to assess streambank stability. These models vary greatly in parameter selection and precision, which has implications for the scale and applications for which they are relevant. Models such as Bank Stability Toe Erosion Model (BSTEM) uses pore water pressure, hydraulic conductivity, root reinforcement values, and site specific geotechnical data (e.g., friction angle, critical shear stress, etc.) to parameterize a model used to predict erosion at a specific location (Simon et al. 2003). Bank Erosion Hazard Index (BEHI) is a field-based index used to predict erosion potential at the reach-scale using several measures of stream channel geometry (e.g., bank height/bankfull height ratio, bank angle, root depth/bank height ratio) and riparian vegetation (e.g., surface protection, root density) (Rosgen 2001 - Appendix Ia) to produce a score used to predict streambank erosion potential. The index is widely used in NCD and has proven to be a useful predictor (Van Eps et al. 2004), but has also received criticism as a poor predictor (Harmel et al. 1999). Inconsistencies in BEHI performance could be the result of unmeasured variables unique to each watershed, or due to an element of subjectivity that differs between researchers.

Other models such as ArcView Generalized Watershed Loading Function (AVGWLF) have been developed to predict erosion rates over large spatial extents using a GIS framework. The model estimates sediment contributions from streambanks using a simple equation for lateral erosion rate (LER),

$$
\text { LER }=\mathrm{aQ} 0.06
$$

where "Q" is mean monthly discharge, 0.06 is a constant based on a global study of streambank erosion (Rutherford 2000), and "a" is a constant based on soil erodibility, precipitation, infiltration, and runoff. A monthly estimate of eroded sediment from streambanks is derived by multiplying LER by the total length of the stream channel (Evans et al. 2003). 
Recent improvements in GIS technologies include incorporation of Bayesian probability modeling into resource management. Bayesian reasoning is an inductive method used in disease diagnosis (Aspinall 1992), mineral exploration (Agterberg et al. 1993), and wildlife habitat modeling (Aspinall 1992; Phillips et al. 2006). A specific approach called "Weights-of-Evidence" uses map integration and map correlation to generate a probability of occurrence for a resource of interest. Weights-of-evidence models are used to find valuable minerals by overlaying maps of environmental features (e.g., geologic maps) to locate areas where a sufficient number of co-occurrences of map features indicate a greater probability of mineral occurrence (Boleneus et al. 2001; Agterberg et al. 1993) (Figure 4). Several studies have evaluated the weights-of-evidence approach for modeling landslide susceptibility, and have shown utility of this method for predicting the occurrence of landslides using predictor map layers that represent topography, hydrology, land cover, etc. (Dahal et al. 2008; Moghaddam et al. 2007; Regmi et al. 2010). Another popular probability modeling approach used in GIS is maximum entropy, which is used to predict species distributions from species presence data (Dudik et al. 2007; Pearson 2007). Maximum entropy is used to estimate a target probability distribution of a feature (i.e., species, mineral, etc.) as a function of environmental variables (i.e., geology, elevation, etc.), but differs from weights-of-evidence in that only presence of the feature of interest is needed to train the model. Maximum entropy is especially useful for modeling with incomplete information because it "agrees with everything that is known but carefully avoids assuming anything that is not known" (Jaynes 1989). The application of probability models in new areas of natural resource science provides potential for addressing environmental problems at larger scales with greater precision (Agterberg et al.1993).

Estimating streambank erosion

Streambank erosion occurs in three major ways: sub-aerial processes, fluvial erosion, and bank failure (Wynn and Mostaghimi 2006). Subaerial processes are a function of temperature and hydrologic regimes within the soil, and often involve freeze-thaw cycling, which reduces soil shear strength. Fluvial erosion is simply the removal of soil particles directly from the streambank by streamflow. Bank failure 
occurs when sub-aerial processes and fluvial erosion induce mass wasting via planar, translational, or cantilever failure. All three processes are strongly tied to variation in climate, land use, soil structure, hydraulics, hydrology, vegetation, among many other factors. Methods for estimating streambank erosion such as repeated erosion pin and stream channel cross section surveys are often used to estimate streambank migration and volumetric sediment loss from a streambank over time. These methods are used for a variety of applications including quantifying the impacts of anthropogenic disturbance on streambank stability (Agouridis et al. 2005), developing models of streambank stability (Hupp et al. 2009; Luppi et al. 2008), and evaluating effectiveness of streambank stabilization (Kondolf 1996; Kondolf 1998; Kondolf et al. 2001; Gerstein and Harris 2005; Smith and Prestegaard 2005).

Recently, remote sensing has been used to quantify erosion as accuracy and availability of these technologies has continued to improve (Thoma et al. 2005; Young et al. 2010). Airborne Light detection and ranging (LiDAR) has proven to be among the most accurate methods for estimating erosion by providing detailed topographic information for the area of interest collected at rates up to $90 \mathrm{~km}^{2} / \mathrm{hr}$ (Young et al. 2010; Kovar and Russel 2008). LiDAR uses a laser beam projected from an aircraft or a ground based system, a sensor to capture reflectance of the laser beam when it contacts an object, and a GPS to record coordinates for the location where the laser beam was intersected by the object (Large and Heritage 2009). LiDAR point data, also called a "point cloud," are used to create digital elevation models (DEMs) that can be analyzed to generate topographic maps with a precision of $15 \mathrm{~cm}$ (Young et al. 2010). Precision and accuracy of LiDAR data are dependent on the number of laser pulses per second, which can range from 5,000 to 100,000 pulses per second. Areas with steep slopes or complex topographies can be difficult to accurately characterize with LiDAR, but if the flight layout can be optimized for GPS with at least six satellites in view, then precisions of $7-8 \mathrm{~cm}$ are theoretically achievable (Large and Heritage 2009). LiDAR data also can be used to map landscape features such as vegetation (i.e., vegetation density, canopy height) based on the return mode used during LiDAR data acquisition. Return modes are based on the relation between the speed of light and flight time (Danson et al. 2009; Goetz 2006), where the first return (i.e., first pulse) measures the range to the first object encountered (e.g., vegetation) and 
the last return measures the range to the last object encountered (e.g., ground surface) (Large and Heritage 2009). Thus, LiDAR data can be used to describe several important characteristics of riparian areas including riparian vegetation and changes in surface topography over time (Goetz 2006). Comparative studies have shown that airborne and terrestrial LiDAR provide correlated estimates of erosion, but that detailed surface topography is better captured with terrestrial LiDAR, thus resulting in greater estimates of volumetric sediment loss when compared to airborne derived estimates (Young et al. 2010).

\section{Study area}

The Cacapon River watershed, a subwatershed of the Potomac River, lies within the Appalachian Mountains in the Ridge and Valley physiographic province of West Virginia and includes the North, Lost, and Cacapon rivers. The watershed drains about 2,320 $\mathrm{km}^{2}$ within Hardy, Hampshire, and Morgan counties. A geologic map developed by the West Virginia Geological and Economic Survey (WVGES 2011) indicates that more than $50 \%$ of the watershed is composed of shale units, with sandstone, alluvium, and limestone making up the remaining portion. The majority (79\%) of land in the watershed is forested, with $19 \%$ agriculture and $2 \%$ residential. The climate in the watershed is humid continental, characterized by hot summers, cold winters, and average annual precipitation near $90 \mathrm{~cm}$ (Gilles 2009). Reports indicate that the Cacapon River watershed has good water quality, and that potential water quality stressors are non-point sources of sediment and nitrogen that enter the river via runoff from agricultural and logging operations, which are heaviest in sections of the Lost and Cacapon rivers. The largest issue with regard to water quality is elevated fecal coliforms, an indicator of animal waste, which is marginal in the Cacapon River (>200 cells/100ml) and exceeds state standards for water-contact recreation in the Lost River ( $>400$ cells $/ 100 \mathrm{ml}$ ) where cattle grazing is the dominant land use (Constantz et al. 1995).

A United States Geological Survey (USGS) gage near Great Cacapon, West Virginia, about 60 $\mathrm{km}$ downstream of a site chosen for stream restoration, was used to conduct a flood frequency analysis, showing a flood with a magnitude of $110 \mathrm{~m}^{3} / \mathrm{s}$ is equivalent to an empirically estimated bankfull event (i.e., recurrence interval 1.5 years - Figure 5) (USGS 2011). The largest flood on record with a discharge 
of 2,480 $\mathrm{m}^{3} / \mathrm{s}$, occurred in 1936 and had devastating effects on local communities along the Cacapon (Douglas 2011). Many landowners who live along the middle Cacapon regularly mention the flood of 1985 , which reached $1,260 \mathrm{~m}^{3} / \mathrm{s}$, only half the largest flood on record, yet left memorable impressions on the landscape and on the minds of local residents (James Brill, personal communication).

An approximately $750 \mathrm{~m}$ reach along the main stem of the Cacapon River was selected for stream restoration using a rating system modified from Strager et al. (2011). The reach is impacted by agriculture (i.e., cattle and hay production), which has led to decreased woody vegetation on both sides of the channel throughout the reach. The dominant forms of vegetation along the reach included mostly seedlings of eastern sycamore (Platanus occidentalis) and black locust (Robinia psuedoacacia), several mature osage orange (Maclura pomifera), and various herbaceous species (e.g., reed canary grass (Phalaris arundinacea), fescue (Festuca spp.), wingstem (Verbisina alternifolia), big bluestem (Andropogon gerardii), Indiangrass (Sorghastrum nutans), and sedges (Carex spp.)). Average water temperature in the reach ranged from $4^{\circ} \mathrm{C}$ in the winter to $23^{\circ} \mathrm{C}$ in the summer. Annual average pH was 7.4, conductivity was $219 \mu \mathrm{S} / \mathrm{cm}$, and turbidity was $12 \mathrm{NTU}$. The streambanks and floodplain throughout the reach are composed of alluvium, the majority of which is sand (i.e., 62\%). The streambed is composed primarily of cobble, gravel, sand, silt, with occasional protrusions of bedrock. Based on the Rosgen classification system, the reach would be classified as a C4 stream type, which is described as slightly entrenched, meandering stream with a well developed floodplain and a gravel bed (Rosgen 1996). Prior to restoration, streambanks within the reach were very steep, only partially vegetated (i.e., $50 \%$ vegetative cover), and had an average BEHI score of 29 indicating high potential for erosion (Selego et al. 2012).

\section{Restoration Project Description}

The stream restoration approach used on the Cacapon River was intended primarily to stabilize eroding streambanks. Effective streambank stabilization and high density riparian planting would 
facilitate accomplishment of several other long-term goals including improved water quality due to decreased sediment and nutrient inputs via streambank erosion, and increased terrestrial and aquatic wildlife abundance and diversity. The restoration techniques used to achieve these goals included creation of a bankfull bench along selected streambanks, construction of log vanes, extensive planting on constructed streambanks and in adjacent buffer zones, and removal of the stressor (i.e., cattle exclusion fencing) (Figure 6). Specifically, six streambank segments were reconstructed to include a bankfull bench and decrease the angle of the bank (Figure 1; Figure 7) and nine log vanes were constructed among the re-contoured streambanks by anchoring two logs into the bank and cabling both logs to a large boulder nearer to the center of the channel (Figure 2; Figure 8). Following construction, anchored geotextiles and coconut fiber logs were positioned along each bank as an erosion control measure.

A total of 1,730 seedlings representing 20 species were planted along the restored reach with highest concentrations of plantings in zone A, extending from the top to the toe of each newly reconstructed streambank to increase bank resistance to erosion (Figure 3). Plantings were also established in zone B, from the top of the bank into the adjacent high terrace to act as a buffer between the river and adjacent land use and enhance wildlife habitat. Riparian plantings covered about 1 hectare along stream right and 0.5 hectares along stream left (Table 1). In addition to planting woody vegetation, each reconstructed streambank was seeded with warm season grasses and wildflowers following a bankfull event that occurred in mid-March, 2011 to increase vegetative cover and the density of pollinator species along sparsely vegetated, reconstructed streambanks. Seeds and seedlings were obtained from Pinelands Nursery, Inc. (Toano, Virginia), Carino Nurseries (Indiana, Pennsylvania), Lawyer Nursery, Inc. (Plains, Montana), Pikes Peak Nursery (Penn Run, Pennsylvania), and Musser Forests, Inc. (Indiana, Pennsylvania). Permanent fencing was constructed along the restored reach by Bland Fencing LLC (Petersburg, West Virginia) to protect streambanks from adjacent land uses and to minimize herbivory. Fencing spanned 955 linear meters along stream right at approximately 10 meters from the top of bank and 467 linear meters along stream left at approximately 1-2 meters from the top of bank. Two strands of temporary electric fencing were also placed around plantings along stream left to provide another 
deterrent to herbivores. A sequence of photos shows taken in 2010 at the four streambank sites monitored in this study show the contrast in appearance of the re-contoured streambanks, log vanes, and plantings compared to the same locations in 2009 (Figure 9).

A control and reference reach that share similar landscape characteristics (i.e., vegetation types, land use, etc.) that did not receive restoration treatments were selected for monitoring to aid in assessing the effects of restoration on streambank stability (Figure 10). The major criteria for selecting these two locations were BEHI scores (Rosgen 2001 - Appendix Ia), which were used to evaluate channel geometry and vegetation within each reach. Average scores at the control site $(\mathrm{BEHI}=37)$ indicate high potential for erosion compared to the reference site $(\mathrm{BEHI}=17)$, which has low potential for erosion. These same sites were also used to assess the effectiveness of riparian planting on vegetation community structure and to evaluate the impact of restoration on water quality in the restored reach. Grab water sampling was conducted upstream of each site and at three locations downstream of selected reaches for quantification of total suspended solids (TSS), total phosphorus (TP), nitrate $\left(\mathrm{NO}_{3}\right)$, and ammonia $\left(\mathrm{NH}_{3}\right)$ (Figure 11). Finally, a YSI Sonde (Global Water Instrumentation, Inc) was deployed upstream and downstream of the restored reach during late spring and early summer one year prior to restoration (2009), during active restoration (2010), and one year following active restoration (2011) to record hourly measures of $\mathrm{pH}$, temperature, conductivity, depth, and turbidity (Figure 12).

Streambank migration rates were measured at a total of 151 locations distributed among 30 stream reaches in the Cacapon River Watershed in development of a model of streambank erosion potential (SEP) (Figure 13). These sites were chosen from an area where four-return airborne LiDAR was flown April 22, 2010 by the West Virginia University Natural Resource Analysis Center (WVU NRAC). LiDAR data was processed to create Log ASCII Standard (LAS) files of the study area, which were used to create raster layers in ESRI ${ }^{\circledR}$ ArcMap $10.0^{\mathrm{TM}}$ to represent various factors that influence SEP.

A 235 meter reach along the Cacapon River was selected for a comparative study of methods for estimating streambank migration and volumetric sediment loss (Figure 14). Eight locations along the 
reach were surveyed in 2010 and 2011 using erosion pin, streambank profile, and combined airborne and terrestrial LiDAR surveys (Figure 15).

\section{References}

Agouridis CT, Edwards DR, Workman SR, Bicudo JR, Koostra BK, Vanzant ES, Taraba JL (2005) Streambank erosion associated with grazing practices in the humid region. American Society of Agricultural Engineers 48:181-190

Agterberg FP, Bonham-Carter GF, Cheng Q, Wright DF (1993) Weights of evidence modeling and weighted logistic regression for mineral potential mapping. In: Computers in Geology, 25 Years of Progress. Oxford, Oxford, pp 13-32

Aspinall R (1992) An inductive modeling procedure based on Bayes' theorem for analysis of pattern in spatial data. International Journal of Geographical Information Systems 6:105-121

Bash JS, Ryan CM (2002) Stream restoration and enhancement projects: is anyone monitoring? Environmental Management 29:877-885

Bednarek AT (2001) Undamming rivers: a review of the ecological impacts of dam removal. Environmental Management 27:803-814

Bernhardt E, Palmer M, Allan J, Alexander G, Barnas K, Brooks S, Carr J, Clayton S, Dahm C, FollstadShah J, Galat D, Gloss S, Goodwin P, Hart D, Hassett B, Jenkinson R, Katz S, Kondolf G, Lake PS, Lave R, Meyer J, O’Donnell T, Pagano L, Powell B, Sudduth E (2005) Synthesizing US river restoration efforts. Science 308:636-637

Boleneus D, Raines G, Causey J, Bookstrom A, Frost T, Hyndman P (2001) Assessment method for epithermal gold deposits in northeast Washington State using weights-of-evidence GIS modeling. USGS report 01-501

Bukaveckas PA (2007) Effects of channel restoration on water velocity, transient storage, and nutrient uptake in a channelized stream. Environmental Science and Technology 41:1570-1576 
Constantz G, Ailes N, Malakoff D (1995) Portrait of a river: the ecological baseline of the Cacapon River. Cacapon Institute. http://www.cacaponinstitute.org. Accessed 2009 March 21

Cooperman MS, Hinch SG, Bennett S, Branton MA, Galbraith RV, Quigley JT, Heise BA (2007) Streambank restoration effectiveness: lessons learned from a comparative study. Fisheries $32: 278-291$

Craig LS, Palmer MA, Richardson DC, Filoso S, Bernhardt ES, Bledsoe BP, Doyle MW, Groffman PM, Hasset BA, Kaushal SS, Mayer PM, Smith SM, Wilcock PR (2008) Stream restoration strategies for reducing nitrogen loads. Frontiers of Ecology and the Environment 6:529-538

Dahal RK, Hasegawa S, Nonomura A, Yamanaka M, Masuda T, Nishino K (2008) GIS-based weights-ofevidence modelling of rainfall-induced landslides in small catchments for landslide susceptibility mapping. Environmental Geology 54:311-324

Danson FM, Morsdorf F, Koetz B (2009) Airborne and terrestrial laser scanning for measuring vegetation canopy structure. In: Heritage GL, Large ARG (eds) Laser Scanning for the Environmental Sciences Wiley-Blackwell, New York

Doll BA, Grabow GL, Hall KR, Halley J, Harman WA, Jennings GD, Wise DE (2003) Stream Restoration: A Natural Channel Design Handbook. Prepared by the North Carolina Stream Restoration Institute and the North Carolina Sea Grant.

Douglas J (2011) The mighty flood of March 1936. The Morgan Messenger. http://morganmessenger.com/news/content/story-7189. Accessed 28 December 2010 Downs PW, Skinner KS, Kondolf GM (2002) Rivers and Streams. In: Perrow MR, Davy AJ (eds) Handbook of Ecological Restoration Vol 2: Restoration in Practice. Cambridge, NY, pp 267-296 Doyle MW, Miller DE, Harbor JM (1999) Should river restoration be based on classification schemes or process models? Insights from the history of geomorphology. Proceedings of the International Conference on Water Resources Engineering, Seattle, Washington. http://www.globalrestorationnetwork.org/uploads/files/LiteratureAttachments/466_should-riverrestoration-be-based-on-classification-schemes-or-process-models.pdf. Accessed 16 July 2010 
Dudik M, Phillips SJ, Schapire RE (2007) Maximum entropy density estimation with generalized regularization and an application to species distribution modeling. Journal of Machine Learning Research 8:1217-1260

Evans BM, Sheeder SA, Lehning DW (2003) A spatial technique for estimating streambank erosion based on watershed characteristics. Journal of Spatial Hydrology 3:1-13

Gerstein JM, Harris RR (2005) Protocol for monitoring the effectiveness of bank stabilization restoration. University of California, Center for Forestry, Berkeley, CA. 24 pp

Gillies N (2009) Cacapon Institute. High View, WV. http://www.cacaponinstitute.org/index.htm. Accessed on 21 September 2010.

Goetz SJ (2006) Remote sensing of riparian buffers: past progress and future prospects. Journal of the American Water Resources Association 42:133-143

Harmel RD, Haan CT, Dutnell RC (1999) Evaluation of Rosgen's streambank erosion potential assessment in northeast Oklahoma. Journal of the American Water Resources Association $35: 113-121$

Harrelson CC, Rawlins CL, Potyondy JP (1994) Stream channel reference sites: an illustrated guide to field technique. USDA Technical Report RM-245

Hasset B, Palmer M, Bernhardt E, Smith S, Carr J, Hart D (2005) Restoring watersheds project by project: trends in Chesapeake Bay tributary restoration. Frontiers in Ecology and the Environment $3: 259-267$

Hey RD (2006) Fluvial geomorphological methodology for natural stable channel design. Journal of the American Water Resources Association 42:357-374

Houck O (2002) The Clean Water Act TMDL Program: Law Policy and Implementation $2^{\text {nd }}$ edn. Environmental Law Institute, Washington D.C. pp 173-178

Hupp CR, Richter JM, Peet RK, Townsend PA (2009) Bank erosion along the dam-regulated lower Roanoke River, North Carolina. Management and Restoration of Fluvial Systems with Broad 
Historical Changes and Human Impacts: Geological Society of America Special Paper 451:97108

Jaynes ET (1989) Papers on probability, statistics, and statistical physics. Kluwer, New York

Kondolf GM (1995) Five elements for effective evaluation of stream restoration. Restoration Ecology $3: 133-136$

Kondolf GM, Micheli ER (1995) Evaluating stream restoration projects. Environmental Management 19:1-15

Kondolf GM (1996) A cross section of stream channel restoration. Journal of Soil and Water Conservation 51:119-125

Kondolf GM (1998) Lessons learned from river restoration projects in California. Aquatic Conservation: Marine and Freshwater Resources 8:39-52

Kondolf GM, Smeltzer MW, Railsback SF (2001) Design and performance of a channel reconstruction project in a coastal California gravel-bed stream. Environmental Management 28:761-776

Kovar J, Russel J (2008) Use of Ground-Based LIDAR to Assess Potential Sediment Loss from Stream Banks in Grazed Pastures. Proceedings of the USDA ASA-CSSA-SSSA Annual Meeting, Texas Large ARG, Heritage GL (2009) Laser scanning - evolution of the discipline. In: Heritage GL, Large ARG (eds) Laser Scanning for the Environmental Sciences Wiley-Blackwell, New York, pp 1-20 Laasonen P, Muotka T, Kivija I (1998) Recovery of macroinvertebrate communities from stream habitat restoration. Aquatic Conservation: Marine and Freshwater Ecosystems 8:101-113

Langendoen EJ, Simon A (2008) Modelling the evolution of incised streams II: stream bank erosion. Journal of Hydraulic Engineering ASCE 134:905-915

Lave R, Doyle M, Robertson M (2010) Privatizing stream restoration in the US. Social Studies of Science 40:677-703

Lepori F, Palm D, Brannas E, Malmqvist B (2005) Does restoration of structural heterogeneity in streams enhance fish and macroinvertebrate diversity? Ecological Applications 15:2060-2071 
Luppi L, Rinaldi M, Teruggi LB, Darby SE, Nardi L (2008) Monitoring and numerical modeling of riverbank erosion processes: a case study along the Cecina River (central Italy). Earth Surface Processes and Landforms. DOI 10.1002/esp.1754

Moghaddam MHR, Khayyam M, Ahmadi M, Farajzadeh M (2007) Mapping susceptibility of landslide by using the weight-of-evidence model: A case study in Merek Valley, Iran. Journal of Applied Sciences 7:3342-3355

Palmer MA, Hart DD, Allan JD, Bernhardt E (2003) Bridging engineering, ecological, and geomorphic science to enhance river restoration: local and national efforts. Proceedings of a National Symposium of Urban and Rural Stream Protection and Restoration, EWRI World Water and Environmental Congress. American Society for Civil Engineers, Reston, VA. http://www.palmerlab.umd.edu/docs/Palmer_et_al_World_Water_Congress_final_Feb_03.pdf. Accessed 8 March 2010

Palmer MA, Bernhardt ES (2006) Hydroecology and river restoration: ripe for research and synthesis. Water Resources Research 42:1-4

Pearson RG (2007) Species' distribution modeling for conservation educators and practitioners. Synthesis. American Museum of Natural History. http://ncep.amnh.org. Accessed 10 October 2010

Phillips S, Anderson R, Schapire R (2006) Maximum entropy modeling of species geographic distributions. Ecological Modelling 190:231-259

Price DJ, Birge WJ (2005) Effectiveness of stream restoration following highway reconstruction projects on two freshwater streams in Kentucky. Ecological Engineering 25:73-84

Regmi NR, Giardino JR, Vitek JD (2010) Modeling susceptibility to landslides using the weight of evidence approach: Western Colorado, USA. Geomorphology 115:172-187

Roni P, Beechie TJ, Bilby RE, Leonetti FE, Pollock MM, Pess GR (2002) A review of stream restoration techniques and a hierarchical strategy for prioritizing restoration in pacific northwest watersheds. North American Journal of Fisheries Management 22:1-20 
Rosgen D (1996) Applied River Morphology $2^{\text {nd }}$ edn. Wildland Hydrology, Colorado

Rosgen, D (2001) Practical method of computing streambank erosion rate. Proceedings of the Seventh Federal Interagency Sedimentation Conference, Reno, NV. http://www.wildlandhydrology.com/assets/Streambank_erosion_paper.pdf. Accessed 3 January 2010

Rosgen, D (2008) Reply to discussion "Critical Evaluation of how the Rosgen classification and associated 'Natural Channel Design' methods fail to integrate and quantify fluvial process and channel responses” by A Simon, M. Doyle, M. Kondolf, F.D. Shields Jr., B. Rhoads, and M. McPhillips. Journal of the American Water Resources Association 44:782-789

Rosgen D (2006) The application of stream classification using the fluvial geomorphology approach for natural channel design: the rest of the story. Proceedings for the World Environmental and Water Resource Congress: Examining the Confluence of Environmental and Water Concerns. American Society of Civil Engineers, Reston, Va. http://cedb.asce.org/cgi/WWWdisplay.cgi?0604034. Accessed 16 May 2010

Russel GD, Hawkins CP, O’Neil MP (1997) The role of GIS in selecting sites for riparian restoration based on hydrology and land use. Restoration Ecology 5:56-68.

Rutherford, I (2000) Some human impacts on Australian stream channel morphology In Brizga SO and Finlayson B (eds.) River management: The Australasian Experience. Wiley, Chichester, pp 221246

Selego SM, Rose CL, Merovich GT, Welsh SA, Anderson JT (2012) Community -level response of fishes and aquatic macroinvertebrates to stream restoration in a third-order tributary of the Potomac River, USA. International Journal of Ecology. doi: 10.1155/2012/75364

Simon A, Thorne CR (1996) Channel adjustment of an unstable coarse-grained alluvial stream: opposing trends of boundary and critical shear stress, and the applicability of external hypothesis. Earth Surface Processes and Landforms 21:155-180 
Simon A, Doyle M, Kondolf M, Shields FD, Rhoads B, McPhillips M (2007) Critical evaluation of how the Rosgen classification and associated 'Natural Channel Design' methods fail to integrate and quantify fluvial processes and channel response. Journal of the American Water Resources Association 43:1117-1131

Simon A, Doyle M, Kondolf M, Shields FD, Rhoads B, McPhillips M (2008) Reply to discussion by Dave Rosgen "Critical evaluation of how the Rosgen classification and associated 'Natural Channel Design' methods fail to integrate and quantify fluvial processes and channel responses". Journal of The American Water Resources Association 44:782-792

Simon A, Collison AJC, Layzell A (2003) Incorporating bank-toe erosion by hydraulic shear into the ARS bank stability model: Missouri River, eastern Montana. Proceedings of the First Interagency Conference on Research in the Watersheds, USDA ARS, Benson, AZ. pp 70-76

Smith EP, El-shaarawi AH, Piegorsch WW (2002) BACI design. Environmetrics 2:141-148

Smith SM, Prestegaard KL (2005) Hydraulic performance of a morphology-based stream channel design. Water Resources Research 41:1-17

Strager M, Rosenberger R (2006) Incorporating stakeholder preferences for land conservation: weights and measures in spatial MCA. Ecological Economics 57:627-639

Strager MP, Anderson JT, Osbourne JD, Fortney R (2011) A three-tiered framework to select, prioritize, and evaluate potential wetland and stream mitigation banking sites. Wetlands Ecology and Management 19:1-18

Thoma DP, Gupta SC, Bauer ME, Kirchoff CE (2005) Airborne laser scanning for riverbank erosion assessment. Remote Sensing of Environment 95:439-501

U.S. EPA (2011) Watershed assessment, tracking, and environmental results. http://iaspub.epa.gov/waters10/attains_nation_cy.control\#STREAM/CREEK/RIVER. Accessed 15 November 2011

U.S. Geological Survey Gauging Station. Great Cacapon, WV. www.waterdata.usgs.gov/usa/nwis/uv?site_no=01611500. Accessed on 23 August 2011. 
Van Eps MA, Formica SJ, Morris TL, Beck JM, Cotter AS (2004) Annual sediment loads from streambank erosion in the White Fork watershed. Measurement 303(d). http://streams.osu.edu/streams_pdf/vaneps.pdf. Accessed 15 November 2009

Vitalis K, Manoliadis O (2002) A two-level multicriteria DSS for landfill site selection using GIS: case study in western Macedonia, Greece. Journal of Geographic Information and Decision Analysis 6:49-56

Waters TF (1995) Sediment in Streams: Sources, Biological Effects, and Control. American Fisheries Society Monograph 7.

West Virginia Geological and Economic Survey (2011) Mont Chateau Research Center. http://www.wvgs.wvnet.edu/. Accessed 8 March 2011

Wohl E, Angermeier PL, Bledsoe B, Kondolf GM, MacDonnel L, Merrit DM, Palmer MA, Poff NL, Tarboton D (2005) River restoration. Water Resources Research 41:1-12

Wolman MG, Miller JP (1960) Magnitude and frequency of forces in geomorphic processes. Journal of Geology 68: 54-74

Wynn T, Mostaghimi S (2006) The effects of vegetation and soil type on streambank erosion, southwestern Virginia, USA. Journal of the American Water Resources Association 2:69-82

Young AP, Olsen MJ, Driscoll N, Flick RE, Gutierrez R, Guza RT, Johnson E, Kuester F (2010) Comparison of airborne and terrestrial Lidar estimates of seacliff erosion in southern California. Photogrammetric Engineering \& Remote Sensing 76:421-42 
Table 1. Riparian plantings in areas where bankfull benches were constructed along a reach of the Cacapon River, West Virginia.

\begin{tabular}{lcccc}
\hline Species & Stream Right & Stream Left & Type & Pollinator \\
\hline Sycamore (Platanus occidentalis) & 25 & 0 & Tree & no \\
Cottonwood (Populus deltoides) & 26 & 24 & Tree & no \\
Elderberry (Sambucus canadensis) & 50 & 50 & Shrub & yes \\
Black Willow (Salix nigra) & 0 & 25 & Tree & no \\
Silky cornel (Cornus amomum) & 25 & 25 & Shrub & yes \\
Streamside alder (Alnus serrulata) & 40 & 30 & Shrub & no \\
Buttonbush (Cephalanthus occidentalis) & 99 & 51 & Shrub & yes \\
Redbud (Cercis canadensis) & 70 & 30 & Shrub & yes \\
Winterberry (Ilex verticillata) & 60 & 40 & Shrub & yes \\
Spicebush (Calycanthus floridus) & 70 & 30 & Shrub & yes \\
Swamp White Oak (Quercus bicolor) & 100 & 48 & Tree & no \\
Swamp Oak (Quercus palustris) & 60 & 40 & Tree & no \\
Grey dogwood (Cornus racemosa) & 60 & 40 & Shrub & yes \\
Persimmon (Diosyros virginiana) & 75 & 0 & Tree & no \\
Choke cherry (Prunus virginiana) & 60 & 40 & Shrub & yes \\
Black haw (Viburnum prunifolium) & 60 & 40 & Shrub & yes \\
American basswood (Tilia americana) & 80 & 40 & Tree & yes \\
Wild plum (Prunus americana) & 50 & 0 & Shrub & yes \\
Rough arrowwood (Viburnum dentatum) & 68 & 32 & Shrub & yes \\
Wild crabapple (Malus coronaria) & 67 & 0 & Shrub & yes \\
Total & 1145 & 585 & & \\
\hline
\end{tabular}

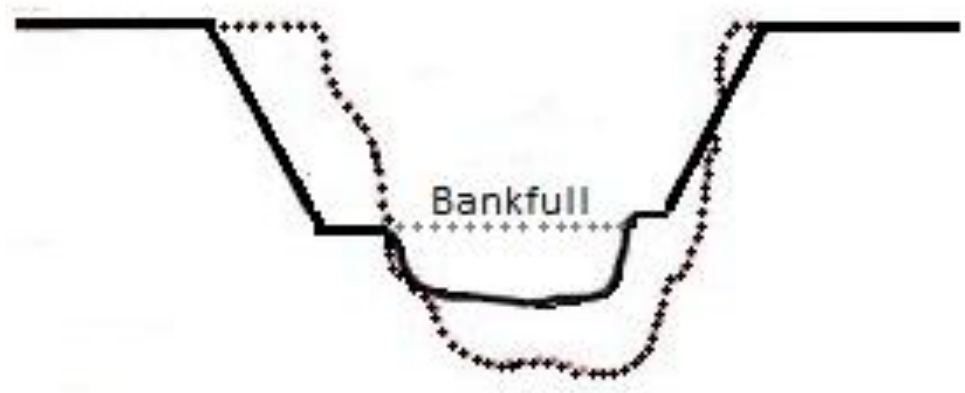

Figure 1. Diagram of a cross section of a bankfull bench adapted from Doll et al. (2003) similar to constructed reaches in a 750 meter restored reach of the Cacapon River. The dotted line represents the old channel and the solid line represents the newly constructed channel. 


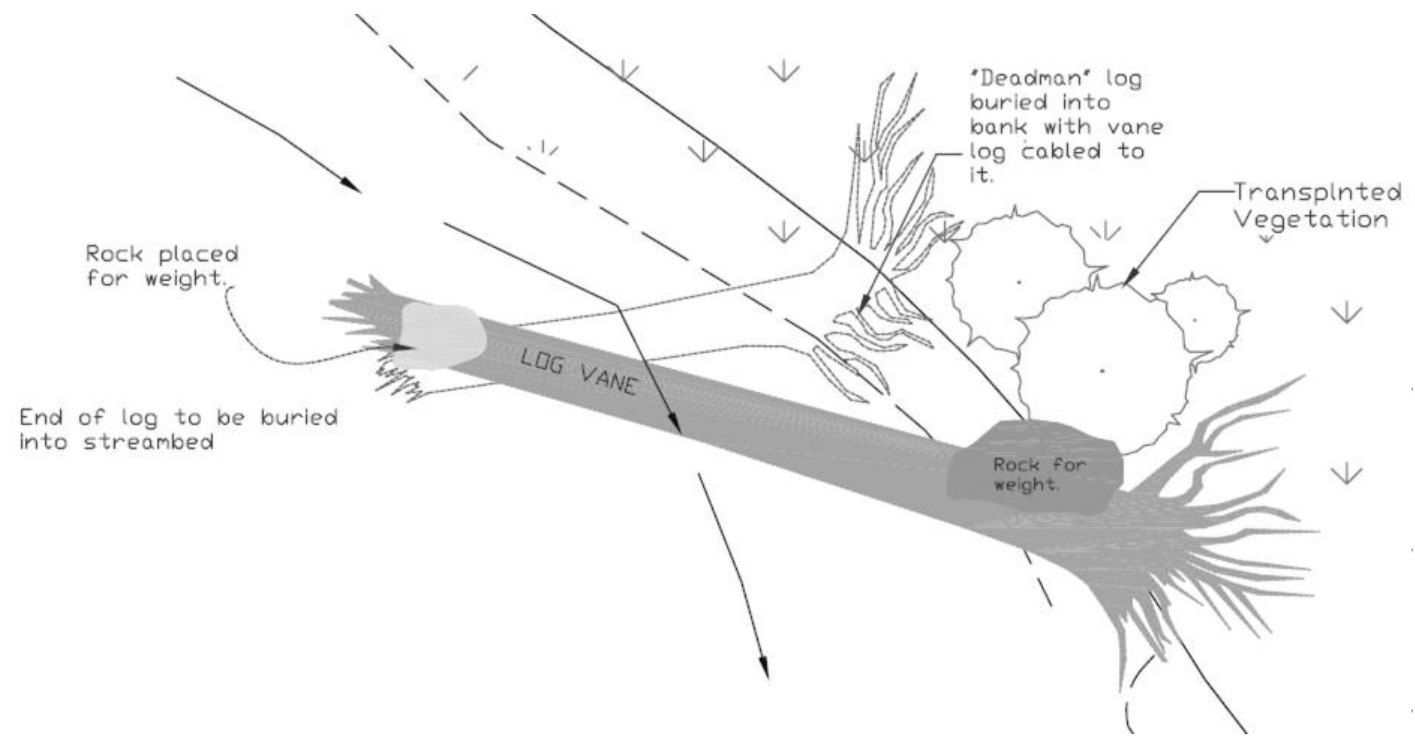

Figure 2. Diagram showing a log vane similar to that constructed on the Cacapon River, West Virginia. Nine log vanes were constructed in the restored reach to reduce bank stress on the toe to prevent fluvial erosion during low flow. The arrows indicate the location of the thalweg.

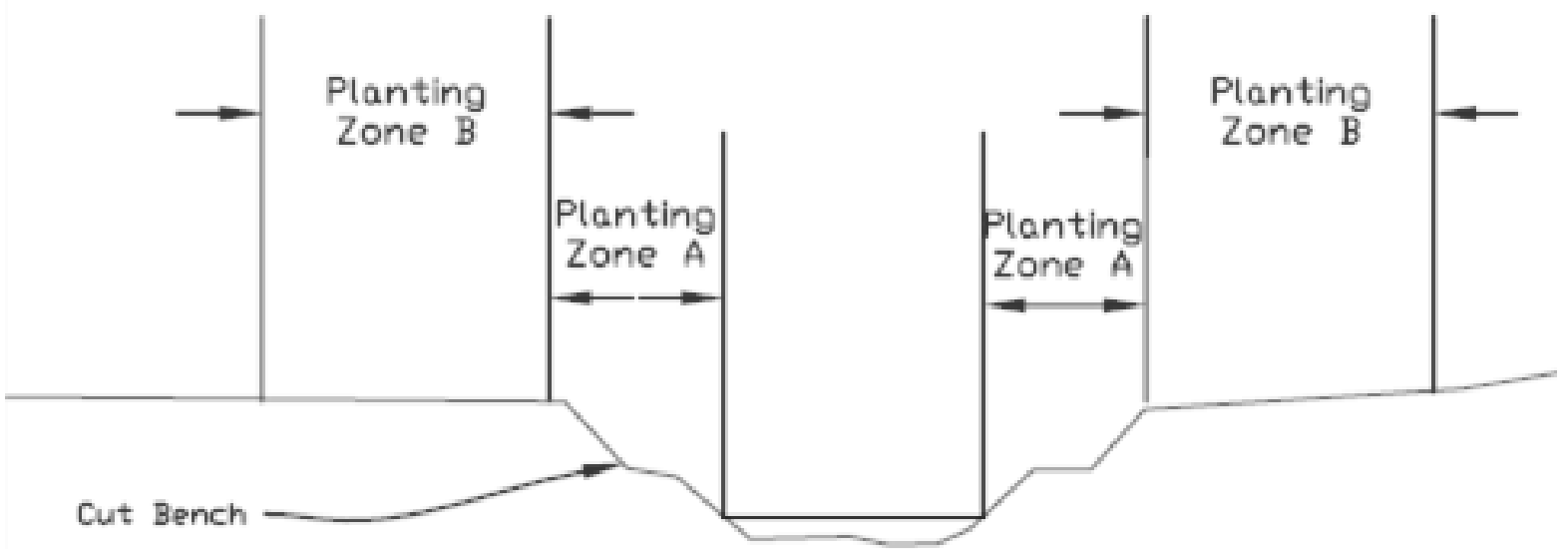

Figure 3. Cross section diagram of a general planting plan for a two-stage channel used in restoration of a 750 meter reach of the Cacapon River, West Virginia. 


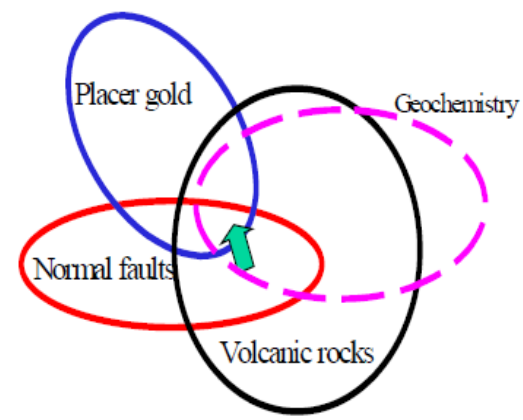

Figure 4. Venn diagram from Boleneus et al. (2001) showing the area of highest probability of gold occurrence indicated by the green arrow.

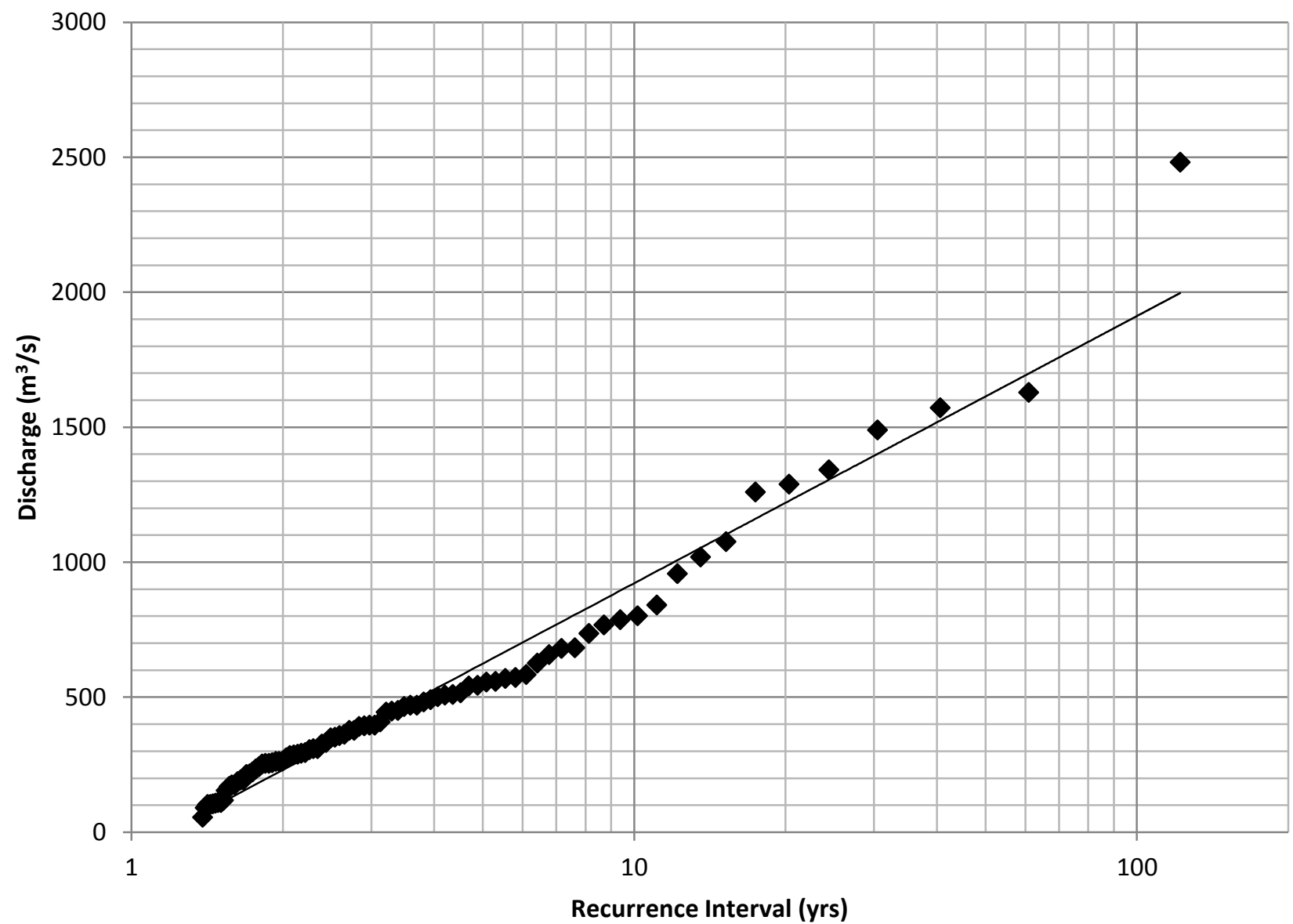

Figure 5. Flood frequency curve generated from peak discharge data from the Cacapon River United States Geological Survey gage 01611500 near Great Cacapon, West Virginia. The curve shows that a flow event of $110 \mathrm{~m}^{3} / \mathrm{s}$ corresponds to the empirically estimated 1.5 year flow, or bankfull event, which is considered to be the dominant discharge among streams in the humid, eastern U.S. 


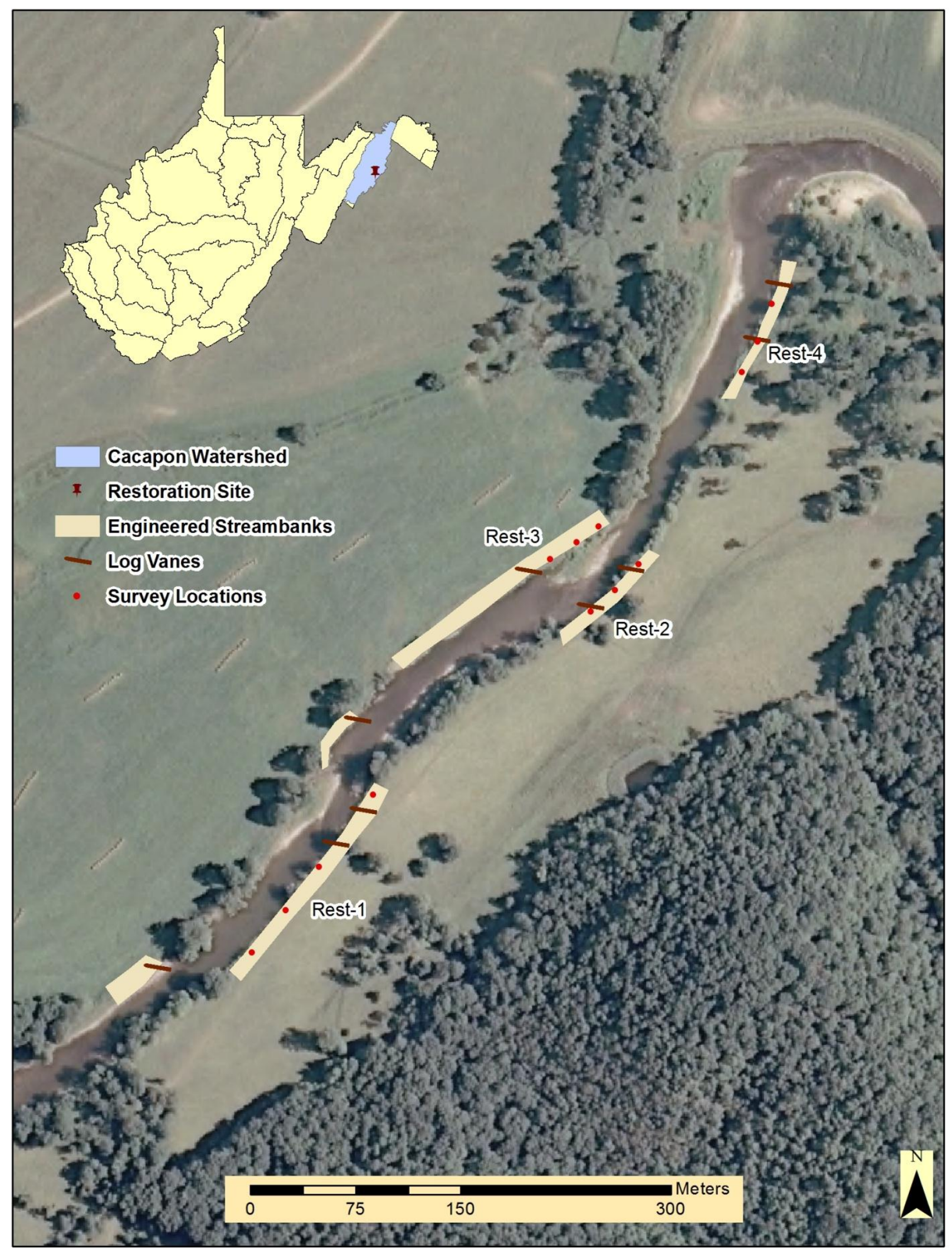

Figure 6. Aerial image with overlays showing location of reconstructed streambanks, in-stream structures, and site names in a reach of the Cacapon River, West Virginia selected for stream restoration. 


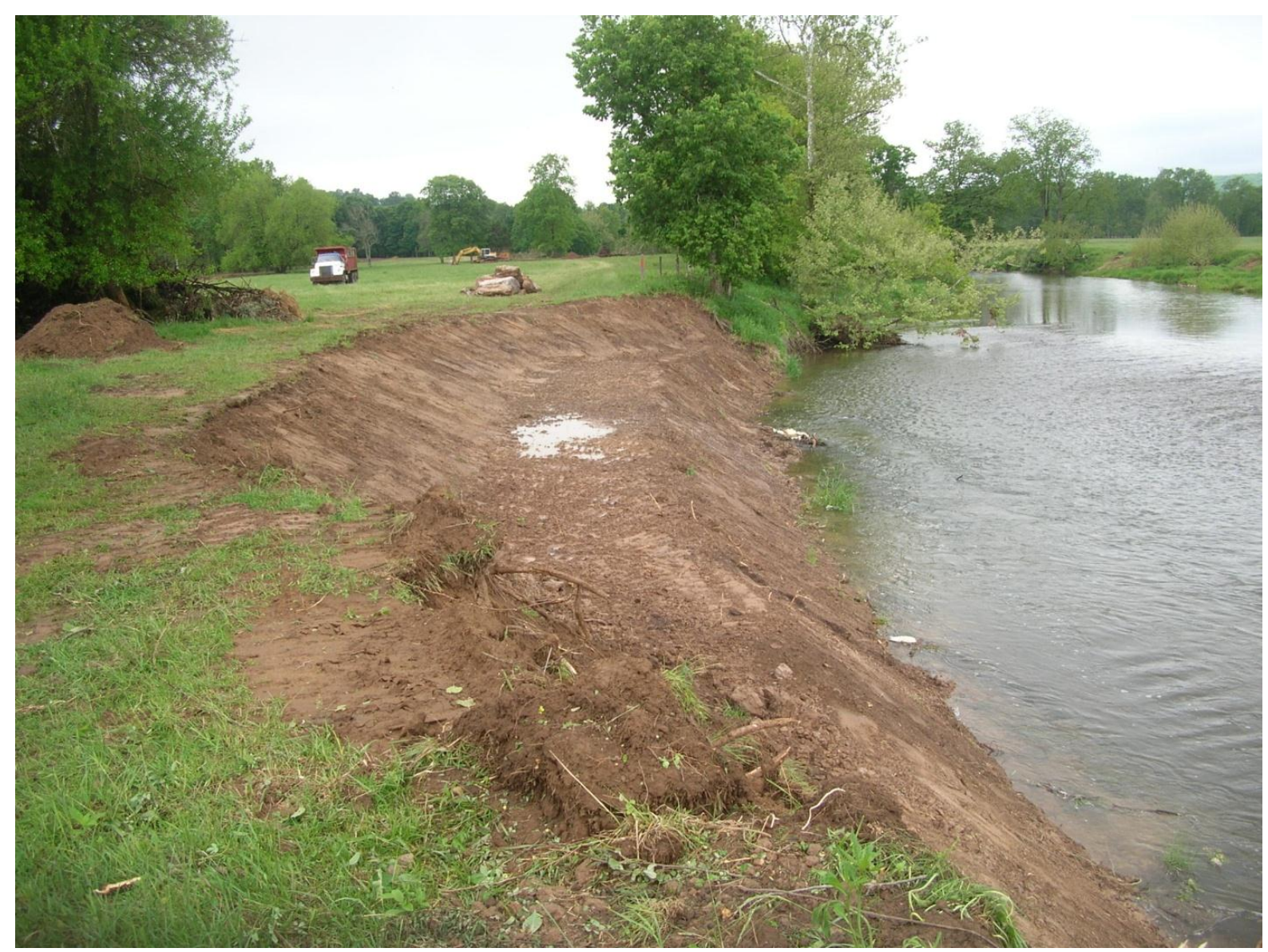

Figure 7. Photo taken at the restoration site that shows a recently excavated bankfull bench intended to stabilize the streambank by allowing high energy water to expand onto a floodplain constructed at bankfull elevation. 


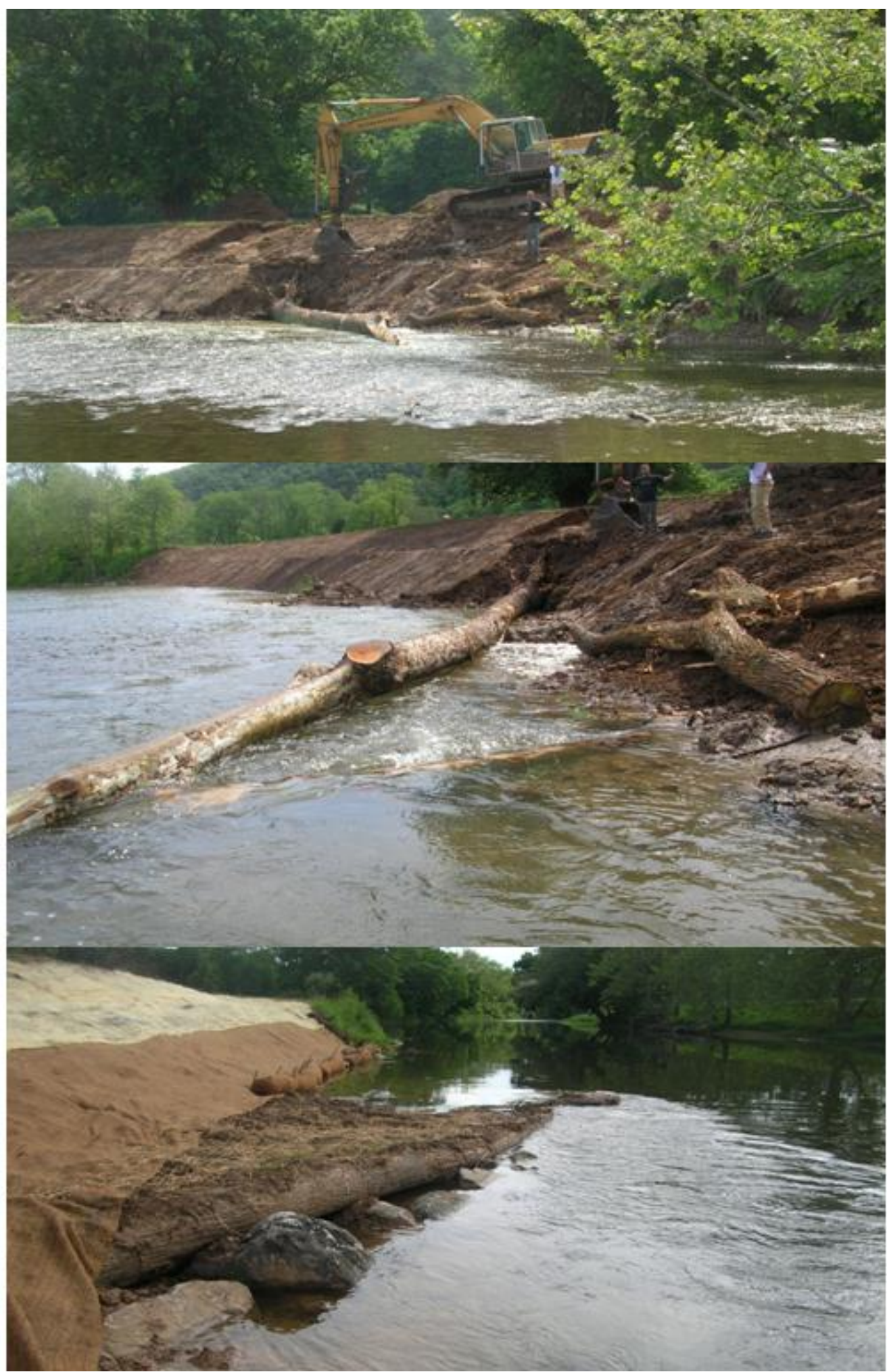

Figure 8. Sequence of photos showing log vane construction at the restoration site designed to reduce shear stress on the streambank. The photo in the center shows how the vane is cabled to a second log under the water, which is also anchored in the bank. Both logs are cabled to a large boulder nearer to the center of the channel. On the upstream side of the vane in the bottom photo are coconut fiber logs, which were installed throughout the reach along reconstructed streambanks to reduce toe erosion. 

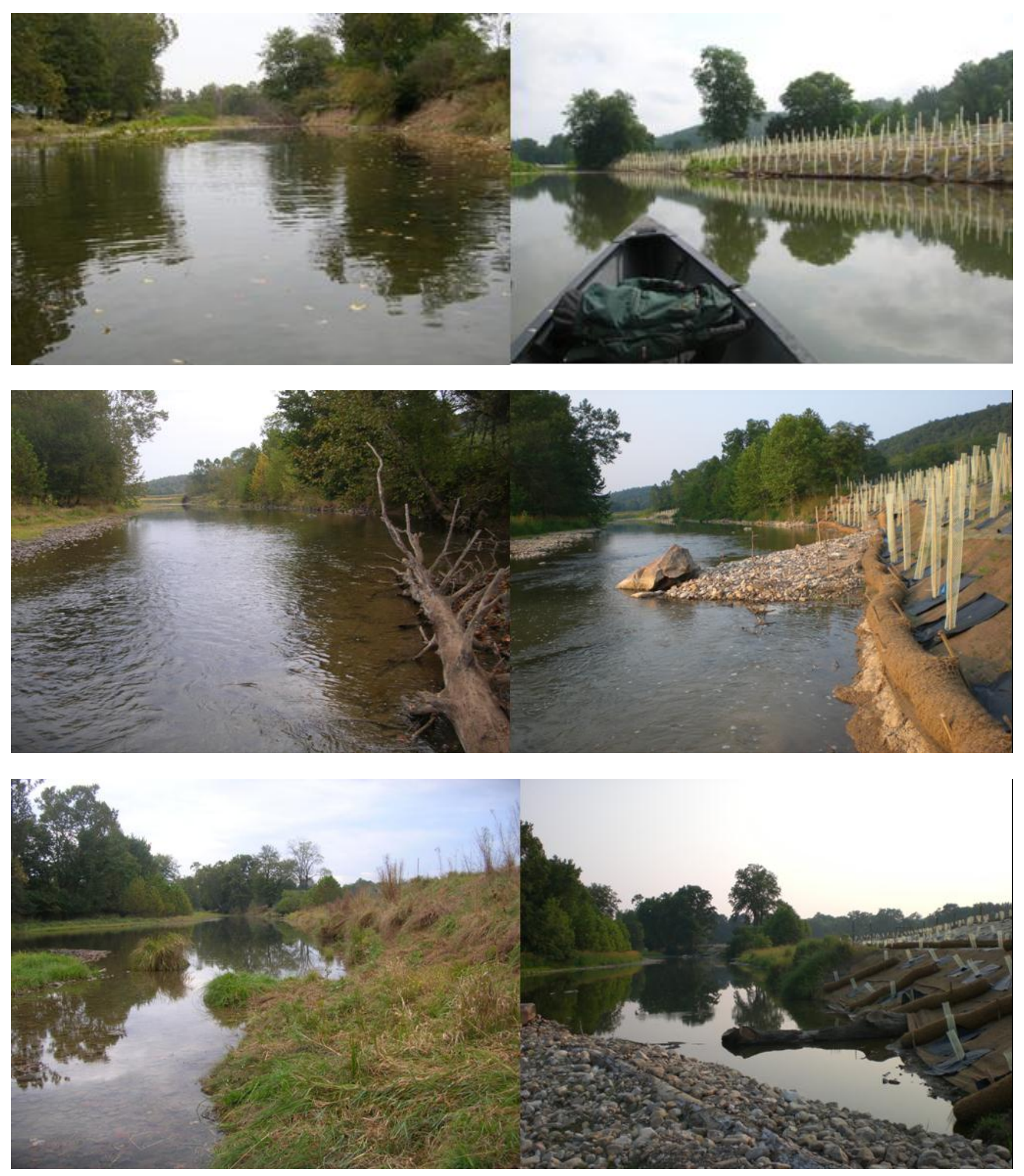


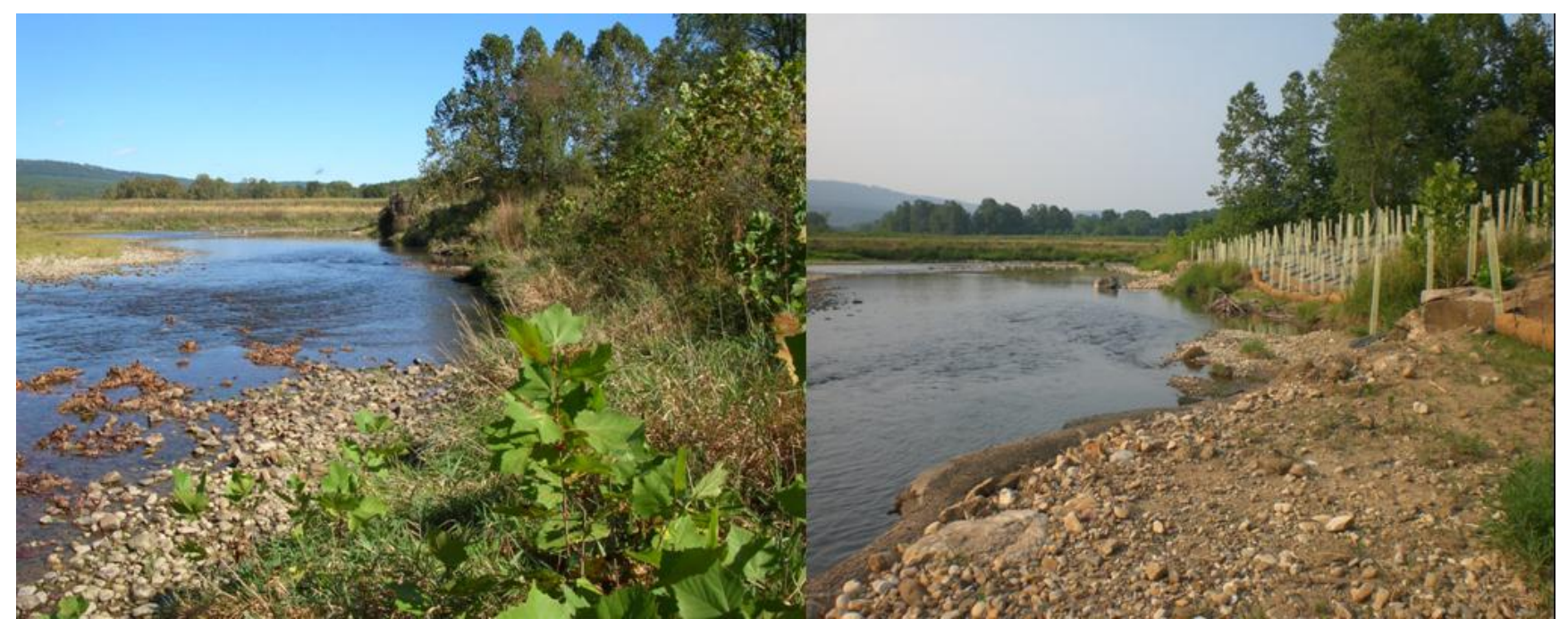

Figure 9. A sequence of photos taken before (left - June 2009) and after (right - July 2010) stream restoration along a reach of the Cacapon River, West Virginia. Photos show, in descending order, Rest-1 (looking downstream), Rest-2 (looking downstream), Rest-3 (looking upstream), and Rest-4 (looking downstream). 


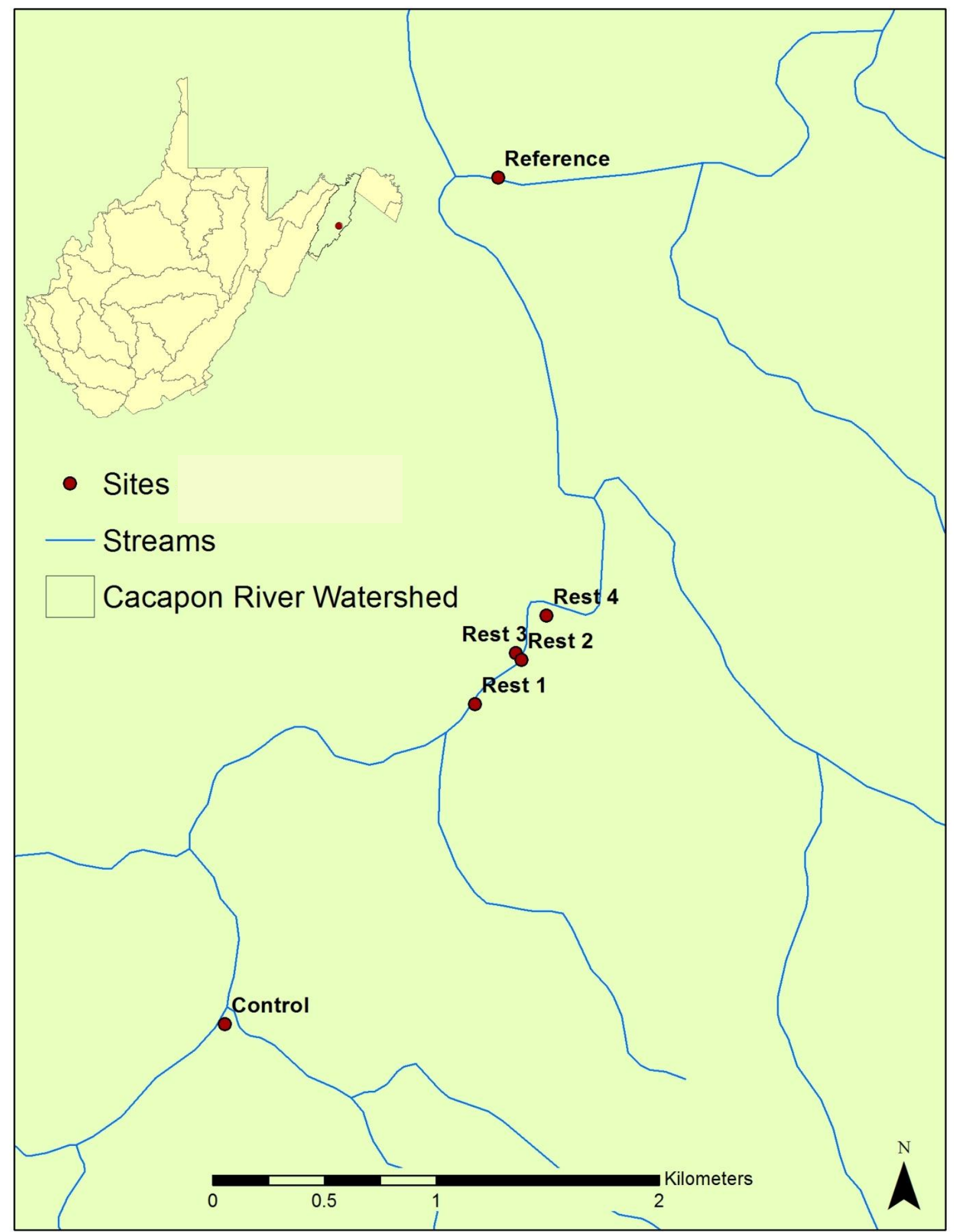

Figure 10. Map showing the location of the Cacapon River Watershed and sites chosen to evaluate the effectiveness of streambank stability treatments. Sites labeled "Rest" are sites that were restored in 2010. 


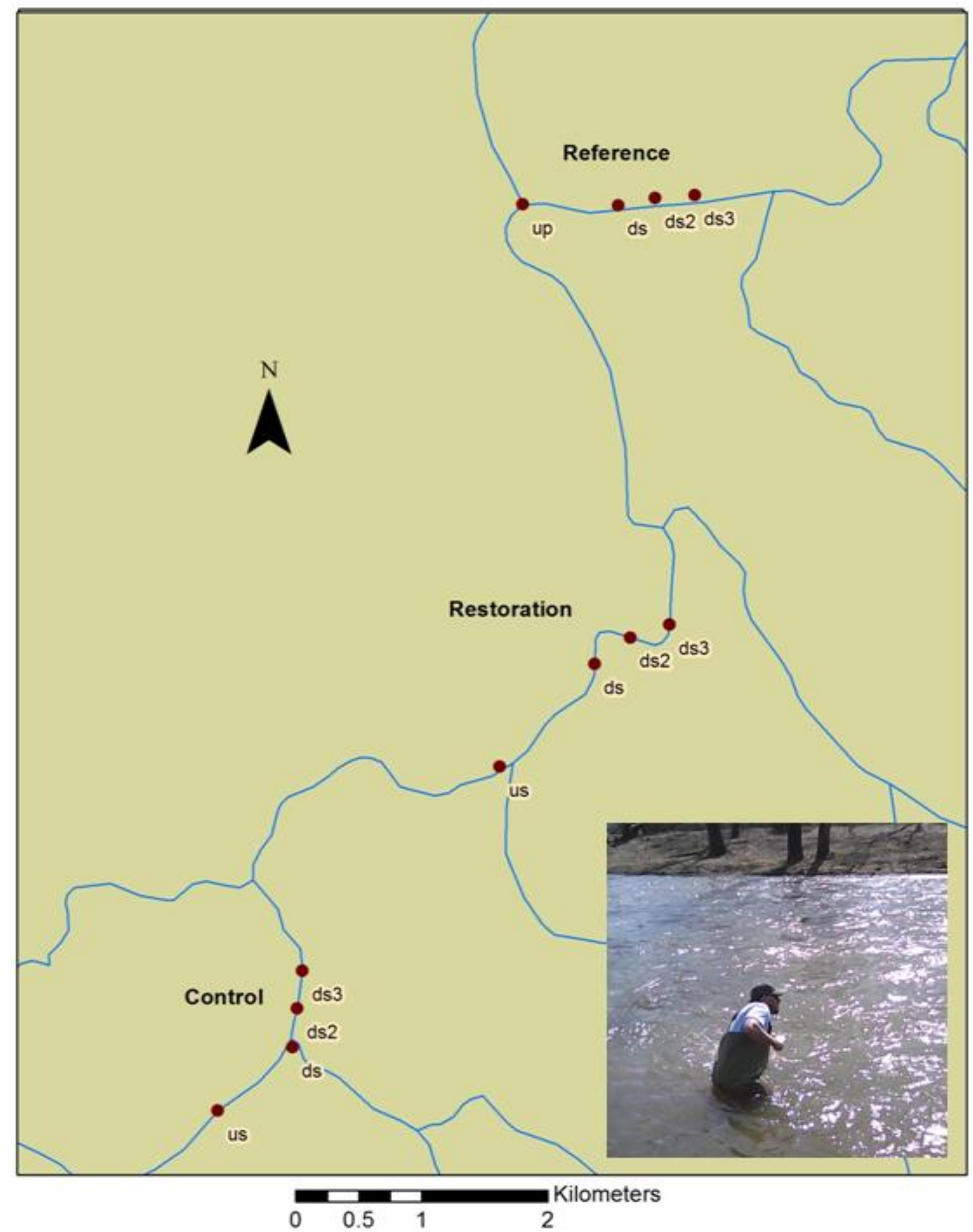

Figure 11. Map showing the location of the Cacapon River watershed and sites chosen to evaluate the effectiveness of stream restoration on water quality. The photo in the bottom right corner of the map shows grab sampling during the largest flood event that occurred during the monitoring period (i.e., 440 $\left.\mathrm{m}^{3} / \mathrm{s}\right)$. 


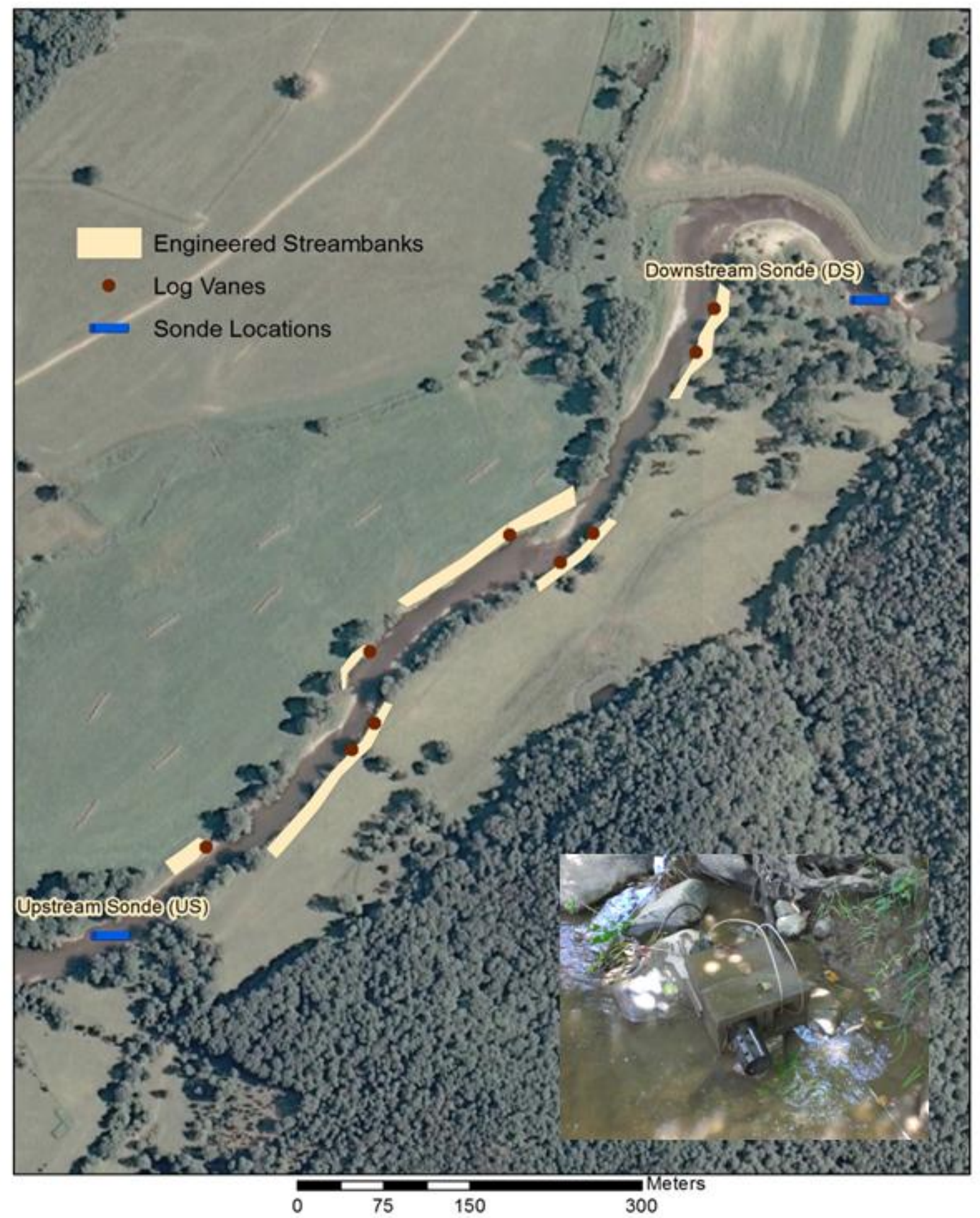

Figure 12. Map showing the location of water quality Sondes that continuously monitored temperature, $\mathrm{pH}$, conductivity, turbidity, and stream depth upstream and downstream of a restored reach along the Cacapon River, West Virginia. Sondes were deployed June - July before (2009) during (2010) and one year after (2011) stream restoration. The photo in the bottom right corner of the map shows a Sonde cabled to two cinder blocks ready for deployment. 


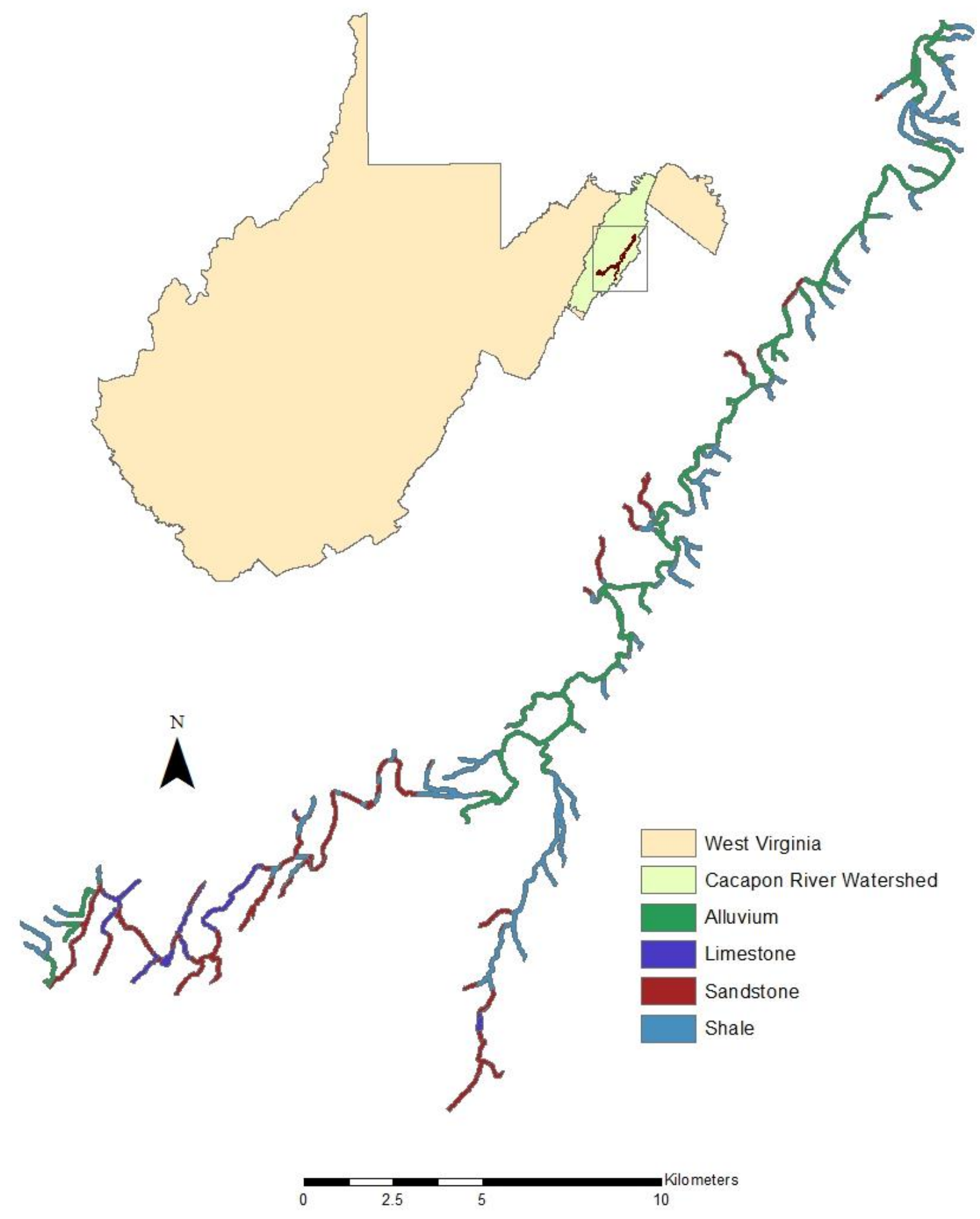

Figure 13. West Virginia Geological Survey (WVGES) map of the underlying geology of a portion of the Cacapon River Watershed where LiDAR data were collected for development of a model of streambank erosion potential (SEP). 


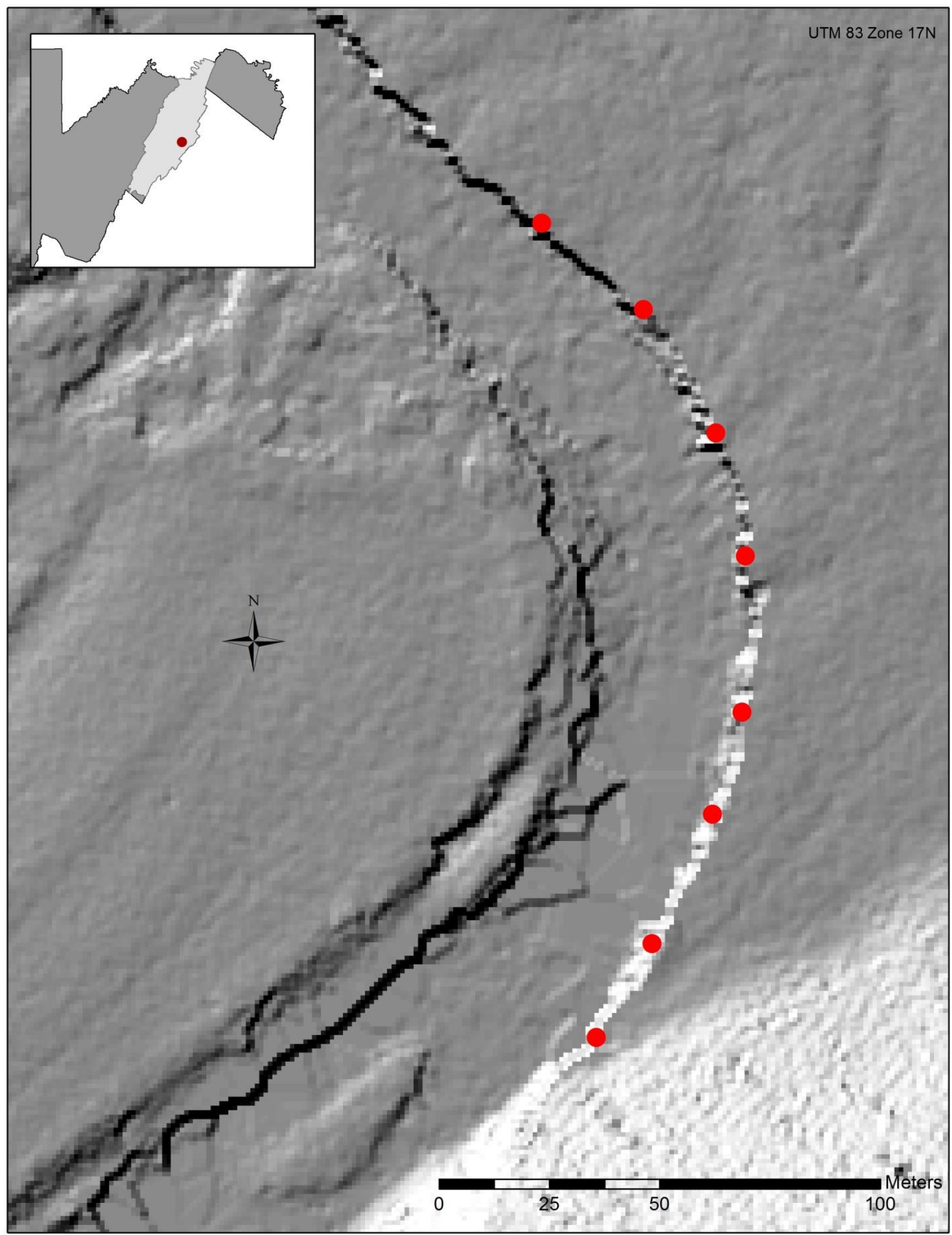

Figure 14. A hillshade map of an area selected for a comparative study of methods used to estimate streambank migration rate. Also shown are the eight survey locations where streambank migration estimates were derived for each method. The hillshade layer was created from airborne LiDAR data collected in April 2010 and was compared with a second DEM created from ground based LiDAR data collected in November 2011. 

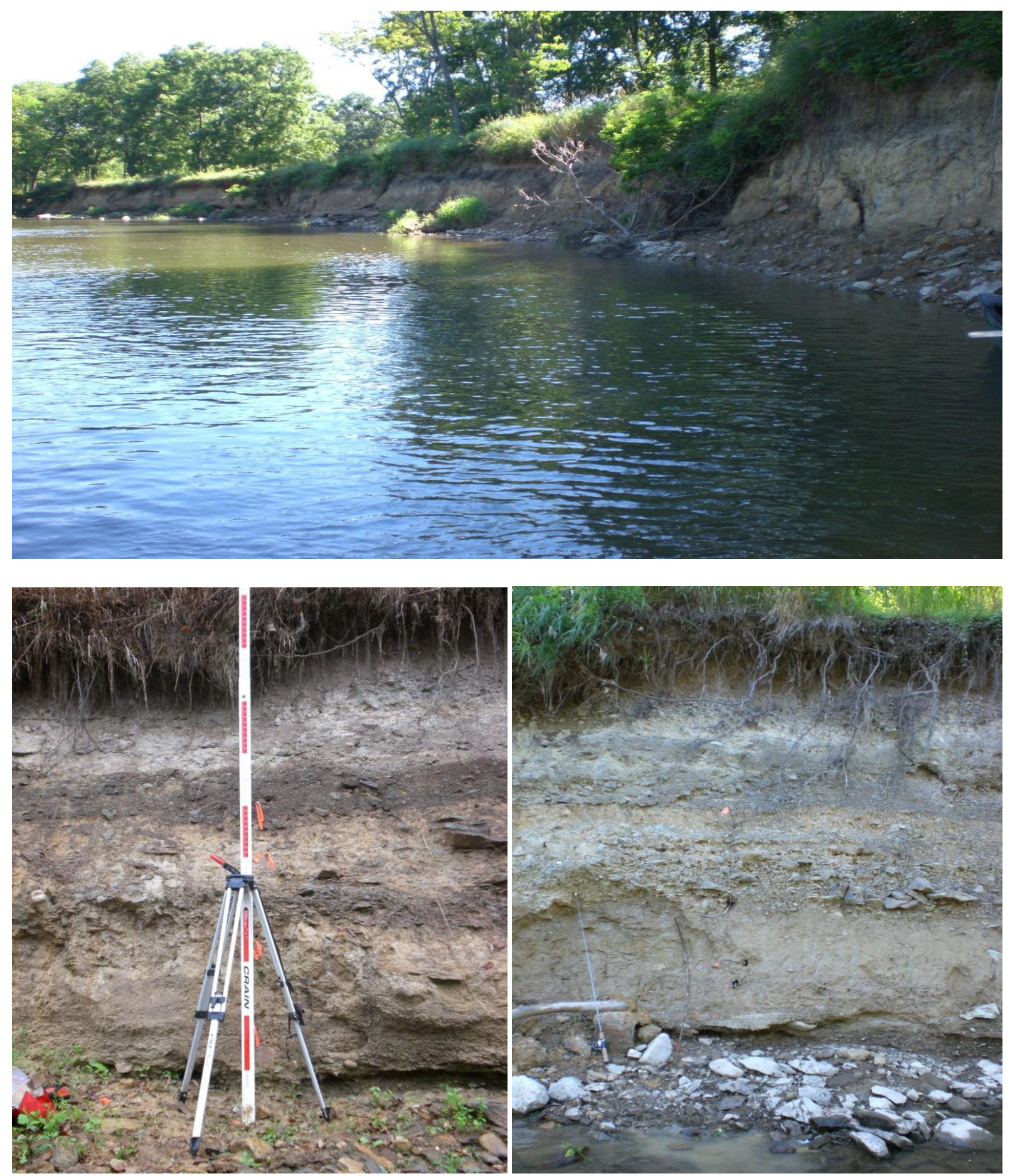

Figure 15. The top photo was taken in June 2011 at the upstream end (looking downstream) of a site selected for a comparison of methods for estimating streambank migration rates. The bottom two photos were taken at G-1 in 2010 (left) and 2011 (right). The photo on the left shows a survey rod on the upstream side of a toe pin used as a benchmark to estimate streambank migration rate. Also shown are flags indicating the location of five erosion pins (i.e., $1.2 \mathrm{~m} \times 1 \mathrm{~cm}$ rebar). The photo on the right shows one pin remaining at this location in 2011. 


\title{
CHAPTER II
}

THE PHYSICAL AND ECOLOGICAL EFFECTS OF MULTIFACETED STREAM CHANNEL RESTORATION IN A CENTRAL APPALACHIAN WATERSHED

\author{
Jonathan L. Pitchford ${ }^{1}$, LianShin Lin $^{2}$ Danny Welsch ${ }^{3}$, and James T. Anderson ${ }^{1}$ \\ ${ }^{1}$ West Virginia University, Division of Forestry and Natural Resources, PO Box 6125, \\ Morgantown, WV 26506-6125 \\ *Corresponding Author e-mail: jpitchfo@mix.wvu.edu \\ ${ }^{2}$ West Virginia University, Department of Civil and Environmental Engineering, \\ PO Box 6103, Morgantown, WV 26506-6125 \\ ${ }^{3}$ Canaan Valley Institute, 494 RiverStone Road, Davis, WV 26260
}

Written in the style of:

Environmental Management 


\begin{abstract}
Stream restoration is occurring in the United States at unprecedented rates; however, pre- and postassessment is often lacking, which undermines the progress of restoration science. The purpose of this study was to examine the effects of reach-scale stream restoration on vegetative community structure, streambank stability, and water quality along a tributary of the Potomac River within the Chesapeake Bay watershed. The restoration approach included re-contouring streambanks to include a bankfull bench, establishment of log vanes to reduce bank stress, and extensive planting of woody vegetation to enhance streambank stability and riparian integrity. A before-after-control-impact design was used to evaluate the effects of restoration where restored and control reaches were monitored before and after restoration. Results indicated that restoration increased the abundance and diversity of woody vegetation, but had minimal effects on streambank stability and water quality. Increased erosion rates in some portions of the restored reach were attributed to differences in pre-restoration stability, vegetation removal, and soil composition among sub-reaches. No differences in in-stream concentrations of total phosphorus, nitrates, ammonia, and total suspended solids were detected following restoration; however, in-stream turbidity was drastically increased during construction. This study is a clear example of the value of monitoring streambank migration, vegetation communities, and soils to evaluate the effects of stream restoration and to provide insight on potential reasons for treatment failure. Ideally, pre-restoration monitoring should be used to inform project design by determining restoration potential of areas selected for restoration.
\end{abstract}

\title{
Introduction
}

Stream restoration has become a multibillion dollar industry in the United States (U.S.) in spite of looming questions about its overall effectiveness at achieving quantifiable improvement in water quality and ecological health (Kondolf 1996; Palmer and others 2003; Wohl and others 2005; Lave and others 2010; Louhi and others 2011; Sudduth and others 2011). The privatization of stream restoration and the adoption of Natural Channel Design (NCD) by governmental agencies such as the U.S. Environmental Protection Agency, U.S. Fish and Wildlife Service, Natural Resources Conservation Service, and the U.S. 
Forest Service has created dissention between many professionals involved with restoration who often disagree on restoration approach and the scale at which restoration is most effective (Kondolf 1995; Wohl and others 2005; Lave and others 2010). Natural Channel Design is a standardized methodology for stream restoration taught almost exclusively in the form of short courses to private contractors, consultants, and scientists (Lave and others 2010). Other restoration approaches often involve collaborative teams of scientists and engineers that design site specific strategies to meet a set of chosen endpoints (Wohl and others 2005). Although both strategies have proven useful, research indicates that stream restoration is a complex undertaking wrought with uncertainty, where the only way to gauge success or failure is by monitoring key physical and biological variables before and after restoration (Kondolf 1996; Palmer and others 2003; Gerstein and Harris 2005; Wohl and others 2005). Research shows that before-after assessment is rarely conducted to determine project effectiveness (Kondolf 1996; Bash and Ryan 2002; Bernhardt and others 2005), and the small number of published studies relative to the large number of ongoing restoration projects indicates that many are under the assumption that restoration is always effective. However, a close look at the literature reveals that many critically evaluated projects failed to meet expectations (Kondolf and Micheli 1995; Kondolf 1998; Kondolf and others 2001; Smith and Prestegaard 2005). This makes answering basic questions about project effectiveness foundational in restoration science.

Natural Channel Design is a form-based approach to stream restoration where channel dimensions of a reference reach are constructed in the impaired reach and stability of the newly constructed channel is achieved using log vanes, root wads, weirs, etc. Common endpoints of these projects are to stabilize stream channels, protect landholdings and infrastructure, and to improve water quality and ecological health. For NCD projects, the Rosgen classification system is used to classify impaired and reference reaches. Classification helps to determine what approach is needed to restore the impaired reach based on an evolutionary tendency of rivers to follow a predictable sequence of stream types following a disturbance, thus inferring processes (e.g., streambank migration, stream incision) from form (Doll and others 2003). Both the Rosgen classification system and NCD hinge on correct 
identification of bankfull stage. The concept of bankfull originated with the Wolman-Miller Hypothesis, which states that the majority of a river's sediment load is transported during moderate flow events that occur, on average, every $1-2$ years (Wolman and Miller 1960). Thus, the 1.5 year flow event corresponding to a theoretical bankfull is considered the dominant discharge that maintains channel form. Because stream channel form is a product of a wide range of flows, and correct identification of a theoretical bankfull stage in the field is extremely difficult, over-reliance on bankfull has been a heavily criticized component of NCD (Simon and others 2007; Lave and others 2010).

Natural Channel Design is commonly aimed at achieving stability of the channel, and has been criticized as an over-interventionist approach to restoration (Kondolf and others 2001; Lave and others 2010). Theories such as the "intermediate disturbance hypothesis" says that ecological diversity is highest when moderately sized disturbance events occur relatively often (Connell 1978) indicating that dynamic streams can be ecologically healthy. Thus, channels that appear degraded may provide more ecological function than a rigid, static channel where little change occurs from year to year. Even so, continued increases in anthropogenic disturbance (e.g., urbanization, timber harvest, mining, agriculture) have created stream channels that are too dynamic and have lost important ecosystem functions that were prevalent historically. Consequently, there is a need for stream and riparian management and an equally important need for research that improves the way we do river management (Roni and others 2002; Hasset and others 2005; Wohl and others 2005).

A commonly used NCD approach to streambank stabilization involves constructing a bankfull bench, where vertical, poorly vegetated streambanks are reconstructed to create a two-stage channel (i.e., NCD priority three restoration - Appendix IIa). This approach has two major functions, 1) to more easily accommodate flood flows while retaining low flow channel, and 2) to facilitate establishment of riparian vegetation (Kondolf 1996; Doll and others 2003). In theory, creation of a two-stage channel will also enhance wildlife and aquatic habitat and improve water quality by increasing the density of riparian vegetation and by improving floodplain connectivity (Doll and others 2003). This makes bankfull bench construction a good fit for multifaceted restoration strategies aimed at achieving several outcomes. 
However, critical evaluation of this technique is lacking considering the relative newness of this approach. Priority three restoration often includes construction of log vanes to reduce streambank shear stress and decrease toe erosion to circumvent streambank failure (Rosgen 1996; Doll and others 2003; Langendoen and Simon 2008). Also, riparian plantings are used to increase bank resistance to erosive shear forces via increased boundary roughness and tensile strength within streambank soils (Hey 2006; Simon and others 2007; Simon and others 2008). Increased ecosystem functioning resulting from increased channel stability is more readily achieved with strategies that employ a combination of channel reconstruction, construction of in-stream structures, and riparian planting (Downs and others 2002).

Assessment of project success and improvement in river management cannot be achieved without monitoring and hypothesis driven research (Kondolf 1996; Bash and Ryan 2002; Wohl and others 2005; Palmer and Bernhardt 2006). Stream restoration in the Chesapeake Bay watershed typically has three primary goals: riparian management, water quality improvement, and streambank stabilization, yet only $5.4 \%$ (254 of 4700) have conducted basic pre- and post- surveys to determine project effectiveness (Hasset and others 2005). Of projects that did monitor project effectiveness, only $24 \%$ assessed the response of the physical structure of the restored reach over time. Given unprecedented increases in restoration and in resource allocation to restoration (Kondolf and Micheli 1995; Bash and Ryan 2002; Bernhardt and others 2005; Palmer and Bernhardt 2006), it is imperative that monitoring and hypothesis driven research follow suit (Wohl and others 2005).

The first objective of this study was to quantify the effectiveness of a multifaceted stream restoration project within the Chesapeake Bay watershed on the Cacapon River, West Virginia by testing the hypothesis that restoration will enhance riparian integrity, streambank stability, and water quality. In an effort to gage overall project success, we used our data to answer five fundamental research questions related to the effectiveness streambank stabilization (Gerstein and Harris 2005):

1- Does the percentage of streambank with vegetative cover increase after treatment?

2- Does the percentage of unstable streambank decrease after treatment?

3- Does the width to depth ratio of the channel change after treatment? 
4- Does restoration stop bank retreat?

5- Does restoration store sediment locally (i.e., re-build streambanks)?

The second objective of this study was to explain the effects of restoration by exploring relations between streambank stability and a suite of local causative factors commonly associated with streambank erosion. In doing so, we hoped to understand which factors were most important for streambank stability, and how restoration success was affected by these factors.

\section{Methods}

Study Area

The Cacapon River watershed is a subwatershed of the Potomac River basin within the larger Chesapeake Bay watershed. The watershed lies within the Appalachian Mountains in the Ridge and Valley physiographic province of West Virginia and includes the North, Lost, and Cacapon rivers that drain 2,320 $\mathrm{km}^{2}$ within Hardy, Hampshire, and Morgan counties (Constantz and others 1995). More than $50 \%$ of the watershed is underlain by shale units, with sandstone, alluvium, and limestone making up the remaining portion (West Virginia Geological and Economic Survey 2011). The majority of land in the watershed is forested (79\%), with some agriculture (19\%), and residential development (2\%). The climate is humid continental, characterized by hot summers, cold winters, and average annual precipitation near $90 \mathrm{~cm}$ (Gillies 2009). The most recent monitoring report indicated that the watershed has good water quality, and that potential stressors are non-point sources of sediment and nitrogen that enter the river via runoff from agricultural and logging operations, which are heaviest in sections of the Lost and Cacapon rivers (Constantz and others 1995).

An approximately $750 \mathrm{~m}$ reach along the third order, main stem of the Cacapon River was selected for stream restoration using a rating system modified from Strager and others (2011) that ranks potential restoration reaches based on a suite of factors including degree of degradation, landowner cooperation, and restoration expense. Both sides of the river are used for agriculture (i.e., cattle and hay production), which has led to decreased woody vegetation on both sides of the channel. The dominant 
forms of vegetation along the reach included eastern sycamore (Platanus occidentalis), black locust (Robinia psuedoacacia), osage orange (Maclura pomifera), and various grass and herbaceous species (e.g., reed canary grass (Phalaris arundinacea), fescue (Festuca spp.), wingstem (Verbisina alternifolia), big bluestem (Andropogon gerardii), Indiangrass (Sorghastrum nutans), and sedges (Carex spp.)). From 2009 - 2011 average water temperature in the reach ranged from $4{ }^{\circ} \mathrm{C}$ in the winter to $23{ }^{\circ} \mathrm{C}$ in the summer, annual average $\mathrm{pH}$ was 7.4 , conductivity was $219 \mu \mathrm{S} / \mathrm{cm}$, and turbidity was 12 nepholometric turbidity units (NTU). The streambanks and floodplain throughout the reach was composed of alluvium, the majority of which was sand (i.e., $62 \%$ ). The streambed was composed of cobble, gravel, and sand with occasional protrusions of bedrock. Based on the Rosgen classification system, the reach was classified as a C4 stream type, which is a slightly entrenched, meandering stream with a well developed floodplain and a gravel bed (Rosgen 1996). Average bank erosion hazard index (BEHI) score was 29 indicating high potential for erosion (Table 1).

\section{Restoration Project Description}

Project personnel and Canaan Valley Institute (Davis, WV) organized a multifaceted stream restoration approach in the spring of 2010 designed to stabilize eroding streambanks using morphological streambank reconstruction and extensive planting of riparian vegetation. Secondary goals of the project were to improve water quality by decreasing sediment loss from streambanks and increasing buffering capacity of riparian areas, and to increase terrestrial and aquatic wildlife abundance and diversity. The restoration approach included construction of bankfull benches and log vanes along selected streambanks, extensive riparian planting, and cattle exclusion fencing. Specifically, six streambank sub-reaches were reconstructed to include a bankfull bench and decrease the angle of the bank, and nine log vanes were constructed among the re-contoured streambanks by anchoring two logs into the bank and cabling both logs to a large boulder nearer to the center of the channel. Also, 1500 trees and shrubs representing 15 species (e.g., elderberry (Sambucus canadensis), black willow (Salix nigra)) were planted along excavated streambanks with additional trees planted along the entire reach (Appendix IIb). Following 
construction, anchored geotextiles and coconut fiber logs were positioned along each bank as an erosion control measure (Selego 2011; Pitchford 2012 Chapter 1; Selego and others 2012). During the year following restoration, all reconstructed streambanks were seeded with native warm season grasses (e.g., Panicum virgatum) and various wildflowers to enhance herbaceous community diversity.

\section{Experimental Design}

To address the first objective of this study, a Before-After-Control-Impact (BACI) design was used to assess the effects of restoration on riparian vegetation, streambank stability, and water quality (Gerstein and Harris 2005). This approach requires sampling of the restored area and one or more control areas before and after the treatment is applied. The control reach in this study was a candidate site for restoration with an average BEHI score of 37 indicating high erosion potential, but did not receive a treatment. The reference site had a BEHI score of 17 (i.e., low erosion potential) and also did not receive a treatment (Appendix IIc).

Benchmarks were established at 10 locations on both sides of the channel for stream channel cross-sections and 13 locations along the toe of the bank for riparian vegetation and streambank profile surveys. Benchmarks were contained within four separate streambank sub-reaches ranging from $100-$ 200 linear meters along the restoration reach (Appendix IIb). Within each segment, $3-4$ equally spaced replicate survey sites, 30 - $40 \mathrm{~m}$ apart, were surveyed one year before restoration (6/2009), one month before restoration (4/2010), one month after restoration (7/2010), and 11 months after restoration (5/2011). These sites were compared to five replicate survey sites, $30-40 \mathrm{~m}$ apart, within the control and reference reach sampled during the same time periods.

Grab samples of water were collected before and after construction downstream of the restoration, control, and reference reaches quantify the effects of restoration on water quality. Samples were collected seasonally for three years $(2009$ - 2011) in the following locations with respect to each reach: immediately downstream, $100 \mathrm{~m}$ downstream, and $200 \mathrm{~m}$ downstream (Appendix IId). Grab samples were also collected at all locations following three large flow events (3/2/2010, 3/25/2011, and 
5/2/2011) that resulted in flow rates in excess of $42 \mathrm{~m}^{3} / \mathrm{s}$ (USGS 2011). A total of four sampling events took place before restoration and seven events took place after restoration. Additionally, hourly measures of selected water quality variables were taken using a YSI 6920 Sonde water monitoring instrument (Fondriest Environmental, Inc) upstream and downstream of the restoration reach one year prior to restoration (6/2009), during active restoration (6/2010), and one year following active restoration (6/2011) (Appendix IIe).

To address the second objective in this study, a total of 44 permanent benchmarks were established along 11 reaches during the summer before restoration $(6 / 2009-8 / 2009)$ that included the restoration, control, and reference reaches, and an additional 24 survey sites distributed among five other reaches with a range of BEHI scores indicating various levels of erosion potential (Appendix IIf). Within each reach, $3-5$ benchmarks, $30-40 \mathrm{~m}$ apart, were used to evaluate the influence of local factors on streambank stability using the methods outlined below for sampling streambank migration, vegetation communities, and soils.

\section{Riparian Vegetation}

Riparian vegetation was evaluated using a sampling design adapted from Rentch and others (2005) where a $25 \times 20 \mathrm{~m}$ quadrat was established with the $25 \mathrm{~m}$ side parallel to the river and centered on permanent benchmarks used for streambank profile surveys (Appendix IIg). Within the $25 \times 20 \mathrm{~m}$ quadrat, all live woody vegetation was counted to species with the exception of plantings on reconstructed streambanks that were only counted in 2010. All live plantings on reconstructed streambanks were counted to species in 2011. Additionally, ten $1 \times 1 \mathrm{~m}$ quadrats were established, five evenly spaced along the toe of bank and five evenly spaced along the top of bank within which percent cover of herbaceous growth was estimated using the following rating system to represent percent cover for each species and bare ground: $1-5 \%=2.5 \%, 6-25 \%=15.5 \%, 26-50 \%=38 \%, 51-75 \%=63 \%, 76-95 \%=85.5 \%$, and $96-100 \%=98 \%$. 


\section{Streambank Stability}

Cross-sectional surveys were conducted by establishing permanent benchmarks in stable areas at the top of bank on both sides of the channel and taking elevation readings every three meters across the channel using a laser level and a level measuring tape stretched between benchmarks on the top of each bank (Harrelson and others 1994). ESRI ${ }^{\circledR}$ ArcMap 10.0 ${ }^{\mathrm{TM}}$ was used to plot cross-section coordinates and digitize a line between points to represent a stream channel cross-section. To calculate selected response variables, the 'Create Fishnet' tool in the Data Management toolbox was used to provide a common datum for measuring bankfull depth at three meter increments across the channel for all survey years at each survey location. The major response variables assessed using cross-sectional surveys were net percent change in cross-sectional area $(\Delta \mathrm{A} \%)$, absolute percent change in cross-sectional area $(|\Delta \mathrm{A} \%|)$, width/depth ratio (w/d), and Gini coefficient (G) (Olson-Rutz and Marlow 1992). The sign of $\Delta \mathrm{A} \%$ is positive under aggrading conditions and negative under degrading conditions; however, such changes can offset producing a value near zero, therefore $|\Delta \mathrm{A} \%|$ is used to quantify cumulative change (i.e., erosion + deposition ) between surveys. The Gini coefficient $(\mathrm{G})$ is a measure of stream channel shape where a negative $G$ difference $\left(G_{\text {diff }}\right)$ (i.e., $G_{\text {diff }}=G$ post $-G$ pre $)$ indicates the channel is becoming wider and shallower and positive $\mathrm{G}_{\text {diff }}$ indicates that the channel is becoming narrower and deeper (Olson-Rutz and Marlow 1992).

Streambank migration rates were measured by inserting three $122 \mathrm{~cm}$ long, $0.95 \mathrm{~cm}$ diameter reinforcing rods (i.e., erosion pins) arranged in a vertical profile into the bank face using a hammer until almost flush (Luppi and others 2008; Hupp and others 2009). Location of erosion pins and pin length exposed were recorded during each survey. The change in pin length between subsequent surveys was averaged for each survey site and used in a migration rate calculation. Migration rates were calculated in $\mathrm{m} / \mathrm{yr}$ for each survey site by standardizing the average pin reading using the following equation.

$$
\text { (average } \Delta \text { in pin length } \div \text { days between surveys) } \times 365
$$


Streambank profile surveys were used to calculate net change in sediment storage at each site by establishing a benchmark in the lower bank area (Van Eps and others 2004). Surveys were conducted using a level survey rod anchored to a tripod placed directly adjacent to the upstream side of the benchmark. The horizontal distance from the survey rod to the streambank was recorded every $15.2 \mathrm{~cm}$ from the benchmark to the top of the bank using a Bosch ${ }^{\mathrm{TM}}$ DLR130 laser distance measurer. After completing surveys at each site, one surveyed location was chosen at random and re-surveyed to assess measurement error for the site. After completing each streambank profile survey, photos were taken of the bank face, in the upstream direction, and in the downstream direction to help assess changes occurring within monitored reaches over time.

Profile survey coordinates were imported into ESRI® ArcMap 10.0 ${ }^{\mathrm{TM}}$ and a line was digitized between points to represent streambank profiles for each year. Streambank angle was calculated for each digitized profile with Screen Protractor 4.0 TM (Iconico, Inc.) by situating the horizontal arm of the protractor at bankfull elevation and aligning the vertical arm with the top of the bank (Rosgen 1996). Next, profiles for each survey year were overlaid on one another and polygons were digitized to represent soil loss and soil gain between subsequent surveys. The area of each digitized polygon was calculated using the "Calculate Geometry" function in ESRI ${ }^{\circledR}$ ArcMap $10.0^{\mathrm{TM}}$ for use in a mass balance calculation for net change in sediment storage. For the mass balance calculation, net sediment storage calculated for each survey location was averaged for each site then multiplied by the total linear distance of the monitored reach to obtain a volumetric estimate of sediment loss or gain at each site for each year. An example calculation for net change in sediment storage is shown below. If a toe pin was lost between surveys, no survey was conducted at that site and it could not be used in the mass balance calculation.

$$
\begin{aligned}
& \text { Average loss: } 0.29 \mathrm{~m}^{2} \times 160 \mathrm{~m}=-46.9 \mathrm{~m}^{3} \\
& \text { Average gain: } 0.04 \mathrm{~m}^{2} \times 160 \mathrm{~m}=+5.8 \mathrm{~m}^{3} \\
& \text { Total Change }
\end{aligned}
$$


To assess the influence of soil characteristics on streambank stability, a composite soil sample (200 g) was collected in 2009 before surveys were conducted in an area $0.5 \mathrm{~m}$ upstream of each of 44 survey sites. Composite samples were sent to Brookside Laboratories Inc. (New Knoxville, OH) for mechanical analysis using the hydrometer method to quantify the proportions sand $(0.05-2 \mathrm{~mm})$, silt $(0.002-0.05 \mathrm{~mm})$, and clay $(<0.002 \mathrm{~mm})$ in each sample (S171 - ASTM D422-63) (Keller and Gee 2005). Additionally, percent soil phosphorus (P) was quantified using the sodium bicarbonate method (S230 - Olsen and Sommers 1982) and percent nitrogen (N) was quantified using automated combustion (S112 - McGeehan and Naylor 1988) from samples collected from each of 13 survey locations within the restoration reach. The average percentage of each nutrient was used to estimate the quantity of $\mathrm{N}$ and $\mathrm{P}$ entering the river via streambank erosion before and after restoration by multiplying the percentage of each nutrient by net change in sediment storage derived from mass balance calculations.

\section{Water Quality}

Collected water samples were stored on ice and transported to the National Research Center for Coal and Energy (Morgantown, WV) for quantification of total suspended solids (TSS) using method SM20 - 2540D (EPA 160.2), total phosphorus (TP) by inductively coupled plasma-atomic emission spectrometry (EPA 200.7), nitrates $\left(\mathrm{NO}_{3}\right)$ by ion chromatography (EPA 300.0), and ammonia $\left(\mathrm{NH}_{4}\right)$ by semi-automated chlorimetry (EPA 350.1) (Clesceri and others 1996). One half of the detection limit was used in statistical analyses for water samples that contained levels below the detectable limit (Antweiler and Taylor 2008).

A YSI 6920 Sonde water monitoring instrument (Fondriest Environmental, Inc) was deployed upstream and downstream of the restoration reach during June through early July for three consecutive years to record hourly measures of $\mathrm{pH}$, temperature, conductivity, depth, and turbidity. Prior to deployment, temperature, $\mathrm{pH}$, conductivity, and turbidity probes were calibrated using standard procedures (YSI 2010). At time of deployment, an Oakton ${ }^{\circledR}$ handheld $\mathrm{pH}$, temperature, and conductivity 
meter and a $\mathrm{HACH} ~ \circledR ~ 2100 \mathrm{P}$ portable turbidimeter were used to test for accuracy and consistency of all measured variables.

\section{Data Analysis}

To evaluate the effects of restoration, we used woody vegetation abundance, Shannon Weiner diversity of woody vegetation, Shannon Weiner diversity of herbaceous vegetation, the percentage of bare ground, streambank migration rate, and streambank angle from 2009 and 2011 as response variables and treatment (i.e., control, reference, and restoration) and time (i.e., before and after restoration) as explanatory factors in a permutational multivariate analyses of variance (PERMANOVA).

PERMANOVA is a non-parametric form of a multivariate analysis of variance (MANOVA), which partitions sums of squares using Bray-Curtis distance matrices, and was conducted using the package 'vegan' and function 'adonis' within the program R 2.12.1 (R Development Core Team 2011). All models included a term for time (i.e., before or after restoration), treatment (i.e., control, reference, restoration), and the interaction between time and treatment, which was the primary term of interest used to determine treatment effects (Smith 2002). Also included in each model was a second interaction term between time and treatment that contained a factor called "sub-reach," nested within treatment, which allowed testing of treatment effects on each sub-reach within the restoration reach. Follow-up tests for significant PERMANOVAs included analyses of variance (ANOVA) on normally distributed data and ANOVAs on ranks of non-parametric data to again assess the effect of treatment on responses. Following significant ANOVAs, a Tukey's Honest Significant Difference (HSD) post hoc test was used to construct pairwise comparisons between treatments and sub-reaches nested within treatments before and after restoration. A Bonferroni correction (adjusted $P=0.05 / 3$ for treatments; adjusted $P=0.05 / 15$ for subreaches) was used for all $P$ values obtained from pairwise comparisons.

To evaluate the influence of restoration on cross-sectional geometry, three dependent variables derived from stream channel cross-sections including cross-sectional area, width to depth ratio, and Gini coefficient were analyzed with paired differences t-tests where each site served as its own control. Tests 
were conducted on each response variable from 2009 - 2011 to determine if restoration resulted in changes in cross-sectional geometry. Net change in sediment storage before and after restoration calculated from repeated streambank profile surveys within the restored reach was also used as a dependent variable in a paired differences t-test to quantify the effects of restoration on sediment storage before $(2009-2010)$ and after $(2010-2011)$ restoration. A priori significance for all tests was set at $P<$ 0.05 .

A PERMANOVA was also used to evaluate the effects of restoration on water quality where the concentration of $\mathrm{NO}_{3}, \mathrm{NH}_{3}$, TP, and TSS in grab samples of water collected from each sampling location were the response variables and treatment (i.e., control, reference, or restoration) and time (i.e., before or after restoration) were the independent variables. A priori significance for this test was set at $P<0.05$. Continuous monitoring data were analyzed graphically by plotting daily average turbidity recorded by both the upstream and downstream Sondes and water depth on the y-axes and time on the x-axis, which facilitated assessment of differences in upstream and downstream turbidity readings in relation to a covariate, depth.

For the second objective of this study, regression tree analysis was used to model the variation in streambank migration rates using predictor variables derived from vegetation surveys (i.e., woody vegetation abundance, Shannon Weiner diversity of woody vegetation, Shannon Weiner diversity of herbaceous vegetation, percentage of bare ground), streambank profile surveys (i.e., streambank angle), and soils analyses (i.e., percentage of sand, silt, and clay) to recursively partition data into subsets that maximize homogeneity among streambank migration rates while minimizing the sums of squares. Regression tree analysis was used because it is considered ideal for exploring complex data characterized by nonlinear relations, high-order interactions, and missing data (De'ath and Fabricius 2000). This analysis required the 'mvpart' package within the program R 2.12.1 (R Development Core Team 2011). A sample size of 44 observations and 10-fold cross-validations were used to find the tree with the smallest cross-validation error, and the smallest tree with an estimated error within one SE of the minimum cross-validation error. Cross-validation values range from zero to one, where lower values 
indicate good predictive ability (De'ath and Fabricius 2000). Pearson correlation analyses were then used to determine the relation between the percentage of bare ground and streambank migration at each site. Correlation analyses were also used to quantify the relation between migration rates stratified by percentage of sand greater or less than $70 \%$ and percentage of bare ground.

\section{Results}

\section{Riparian Vegetation and Streambank Stability}

We identified 14 species of woody vegetation and 58 species of herbaceous vegetation along the restoration, control, and reference reaches before restoration. Along the restored reach, the most commonly occurring woody species were seedlings of black locust and eastern sycamore, which were abundant along stream right in the restored reach prior to construction. No woody vegetation was found in survey plots on stream left before restoration. Dominant herbaceous species along the restored reach included various sedges (17\%), fescue (14\%), and wingstem (11\%). Herbaceous plots along stream left contained a large percentage of warm season grasses (35\%) including two species, big bluestem and Indiangrass. No warm season grasses were identified on stream right where the dominant cover type of herbaceous plots was bare ground before restoration $(21 \%)$.

Restoration had effects on streambank stability and vegetation variables compared to control and reference reaches from $2009-2011\left(F_{2,29}=11.4 ; P<0.001\right)$ (Figure 1a). One year following the completion of restoration, the average abundance of woody vegetation was higher than control and reference reaches at 39 individuals $(\mathrm{SE}=8.7)\left(F_{2,29}=5.4 ; P<0.05\right)$. A large number of volunteer black locust and eastern sycamore that grew on restored streambanks along stream right during the year following restoration was partially responsible abundance remaining relatively high as only $26 \%$ of plantings survived the year on restored streambanks. Planting survival was different among streambank sub-reaches as indicated by differences in woody abundance $\left(F_{6,29}=4.9 ; P<0.01\right)$. Almost all plantings along sub-reach Rest-3 were lost in the year following restoration where abundance was low compared to sub-reach Rest-2 where survival was higher and was supplemented by volunteer species $(P<0.001)$. 
Restoration increased Shannon-Weiner diversity of woody vegetation $\left(F_{2,29}=5.4 ; P<0.01\right)$ from 0.46 $(\mathrm{SE}=0.18)$, similar to control and reference reaches before restoration, to $1.47(\mathrm{SE}=0.18)$ following restoration, which was higher than both control $(P<0.01)$ and reference $(P<0.01)$ reaches (Figure 1b). The most successful plantings were elderberry (Sambucus canadensis) and swamp white oak (Quercas bicolor) comprising $16 \%$ and $13 \%$ of survivors along restored streambanks, respectively. Restoration had no effect on Shannon-Weiner diversity of the herbaceous community from 2009 - 2011 (Appendix IIh), but resulted in increases in the percentage of bare ground to $30 \%(\mathrm{SE}=3.4)\left(F_{2,29}=3.5 ; P<0.05\right)$, similar to the control reach, but higher than the reference reach $(P<0.01)$ (Figure 1c).

Restoration decreased average streambank angle to $60^{\circ}(\mathrm{SE}=3.8)$ one year after restoration $\left(F_{2,29}\right.$ $=12.1 ; P<0.001)$, which was lower than the control site $(P<0.05)$, and similar to the reference site (Figure 2a). Restoration had no effect on streambank migration rate as average migration rate before restoration was $0.13 \mathrm{~m} / \mathrm{yr}(\mathrm{SE}=0.04)$ compared to $0.05 \mathrm{~m} / \mathrm{yr}(\mathrm{SE}=0.06)$ following restoration; however, responses among sub-reaches varied significantly (Figure 2b). Migration rates at sub-reach Rest-1 were $0.21 \mathrm{~m} / \mathrm{yr}(\mathrm{SE}=0.12)$ before restoration, but decreased to $0.02 \mathrm{~m} / \mathrm{yr}(\mathrm{SE}=0.04)$ following restoration. In contrast, sub-reach Rest-3, which had a migration rate of $0.05 \mathrm{~m} / \mathrm{yr}(\mathrm{SE}=0.02)$ before restoration, increased to $0.33 \mathrm{~m} / \mathrm{yr}(\mathrm{SE}=0.19)$ following restoration. Sub-reach Rest-4 was also relatively stable before restoration as migration rate was $0.04 \mathrm{~m} / \mathrm{yr}(\mathrm{SE}=0.01)$. Erosion pin surveys indicate that this area remained relatively stable following restoration with a migration rate of $0.05 \mathrm{~m} / \mathrm{yr}(\mathrm{SE}=0.04)$. Erosion pins were retained at $100 \%$ of all survey locations along restored, control and reference reaches, and therefore were a reliable estimate of streambank migration rate before and after restoration. Although no surveys were conducted in an area at the downstream end of sub-reach Rest- 4 , photos of the area show that stability decreased following restoration (Figure 3). The retreating streambank abandoned a log vane in the middle of the channel following several large flood events in the spring of 2011.

Width to depth ratio increased $1.2(\mathrm{SE}=0.5)$ from $2009-2011(T=-2.4 ; P<0.05)$ indicating that on average the channel became wider and shallower during the monitoring period (Table 2) (Figure 4). Average absolute value of percent change in cross-sectional area was $10.2 \%(\mathrm{SE}=3.2)$ at Rest- $2 / 3$ 
(i.e., stream channel cross-section extending from Rest-2 to Rest-3) for 2009 - 2010, which was higher than the other sub-reaches. This area experienced the most change because streambanks and log vanes were constructed on both sides of the channel in 2010, and the reconstructed streambank along stream left washed out in April 2010 following three flood events, each with a discharge between $290-350 \mathrm{~m}^{3} / \mathrm{s}$ corresponding to a $2-3$ year recurrence interval (Figure 5). Photos of sub-reach Rest-3 taken $1-2$ days after each of these events show progressive losses of sediment and plantings from this area resulting from each event (Figure 6).

Restoration had no effect on sediment storage $(T=-1.32 ; P=0.24)$; however, repeated streambank profile surveys indicate that $39.3 \mathrm{~m}^{3}$ of soil was lost from the reach before restoration compared to a net storage of $66.6 \mathrm{~m}^{3}$ following restoration. Different responses among sub-reaches were documented (Table 3) as sub-reach Rest-1 lost $41.1 \mathrm{~m}^{3}$ ( $\left.\mathrm{SE}=9.6\right)$ of sediment before restoration compared to a loss of $4.9 \mathrm{~m}^{3}(\mathrm{SE}=5.4)$ after restoration indicating that streambank stability increased along this sub-reach (Figure 7). Sub-reach Rest-3 was relatively stable before restoration as an average of $2.4 \mathrm{~m}^{3}(\mathrm{SE}=0.5)$ of sediment was lost from this area compared to $63.3 \mathrm{~m}^{3}(\mathrm{SE}=12.7)$ of sediment loss after restoration. Average error of streambank profile surveys of $+0.003 \mathrm{~m}$ for $2009-2010$ and $-0.015 \mathrm{~m}$ for 2010-2011 was considered negligible and was therefore not used in calculations of net change in sediment storage. Toe pins used as benchmarks for profile surveys were lost at $38 \%$ of sites along the restored reach before restoration and $31 \%$ of sites after restoration, and loss of benchmarks at Rest- 4 occurred at two of the three survey sites during both monitoring periods making our estimates of sediment storage at this site less reliable.

The average percentage of $\mathrm{N}$ and $\mathrm{P}$ in soil samples collected along the restoration reach was $11 \%$ $(\mathrm{SE}=1.0)$ and $2 \%(\mathrm{SE}=0.1)$, respectively. Using this information in mass balance calculations indicates that $4.4 \mathrm{~m}^{3}$ of $\mathrm{N}$ and $1.0 \mathrm{~m}^{3}$ of $\mathrm{P}$ was lost from the reach in the year before restoration and $11.5 \mathrm{~m}^{3}$ of $\mathrm{N}$ and $1.52 \mathrm{~m}^{3}$ of $\mathrm{P}$ was stored in the reach after restoration (Tables 4 and 5). The average percentage of sand, silt, and clay along the restored reach was $13 \%(\mathrm{SE}=2.1), 25 \%(\mathrm{SE}=4.2)$, and $62 \%(\mathrm{SE}=5.5)$, respectively; however, these percentages varied considerably along the reach as sub-reach Rest-3 
contained $86 \%$ sand $(\mathrm{SE}=2.6)$ and only $6.5 \%$ clay $(\mathrm{SE}=0.17)$ compared to Rest- 1 that contained $41 \%$ sand $(\mathrm{SE}=7.39)$ and $18 \%$ clay $(\mathrm{SE}=4.4)($ Figure 8$)$.

\section{Water Quality - Grab sampling}

Restoration had no effect on nutrient and sediment concentrations in grab samples of stream water $\left(F_{2,90}=0.19 ; P<0.95\right)$ as only slight changes in the concentrations of monitored water quality variables were detected following restoration, and were similar to changes among control and reference reaches. The average concentration of $\mathrm{NO}_{3}$ below the restoration reach before construction was 0.61 $\mathrm{mg} / \mathrm{L}(\mathrm{SE}=0.15)$ compared to $0.64 \mathrm{mg} / \mathrm{L}(\mathrm{SE}=0.21)$ after restoration (Appendix IIi). Average $\mathrm{NH}_{3}$ concentration before restoration was $0.04 \mathrm{mg} / \mathrm{L}(\mathrm{SE}=0.03)$ compared to $0.01 \mathrm{mg} / \mathrm{L}(\mathrm{SE}=0.01)$ after restoration (Appendix IIj). Total P concentrations decreased slightly in samples collected from control, reference, and restoration reaches during the post-restoration monitoring period, and were below detectable limits in the majority of samples (Appendix IIk). The concentration of TSS downstream of the restoration reach was $7.1 \mathrm{mg} / \mathrm{L}(\mathrm{SE}=5.4)$ before construction and $3.4 \mathrm{mg} / \mathrm{L}(\mathrm{SE}=1.4)$ in the postrestoration monitoring period (Appendix IIl).

\section{Water Quality - Continuous monitoring}

Continuous monitoring indicated that before restoration fluctuations in turbidity upstream and downstream of the restoration reach typically reflected changes in water depth (Figure 9). However, as depth decreased following the largest flood event of the pre-monitoring period (i.e., 6/13/20096/15/2009), a spike occurred in downstream turbidity to approximately 100 NTU higher than upstream levels, which continued to decrease with depth. The average difference between upstream and downstream readings (i.e., average downstream turbidity - average upstream turbidity) during the prerestoration monitoring period was $8 \mathrm{NTU}(\mathrm{SE}=3.6)$ indicating that a small amount of sediment originated from the reach during this time. During the active construction phase of restoration no major flood events occurred as indicated by depth readings, which steadily declined during the monitoring 
period; however, the average difference between upstream and downstream turbidity was $168 \mathrm{NTU}(\mathrm{SE}=$ 13.6). Daily average turbidity ranged from $0-64$ NTU upstream of the reach while downstream turbidity levels ranged from 28 - 309 NTU. Large differences between upstream and downstream readings indicate that the reach was a large source of sediment during the active construction phase of the project. A year following completion of restoration, upstream and downstream turbidity levels again coincided for most of the monitoring period. Elevated depth readings and corresponding increases in upstream and downstream turbidity levels indicative of a flood event occurred from 6/28/2011 -6/30/2011. During the falling limb of the event, downstream turbidity increased to 195 NTU while turbidity upstream continued to decrease. The average difference in upstream and downstream turbidity during this period was 30 NTU (SE $=10.3)$ indicating that the reach was a small source of sediment during the post-restoration monitoring period. The ecological effects of increased turbidity in the reach during construction can be seen when comparing average percentage of Ephemeropteran, Plecopteran, and Trichopteran taxa (EPT) of macroinvertebrate samples collected from the reach (Selego 2011) to the average difference between upstream and downstream turbidity during the pre, during, and post-restoration periods (Figure 10). Before and after restoration when the difference in turbidity levels was relatively low, percent EPT taxa was $48 \%$ and $39 \%$, respectively indicating a healthy benthic community; however, during the active construction phase when the average difference in turbidity was 168 NTU, the percentage of EPT taxa fell to $12 \%$.

\section{Stream restoration effectiveness}

The results presented here were used to answer the following questions for effective streambank stabilization (Gerstein and Harris 2005).

\section{1- Did the percentage of streambank with vegetative cover increase after treatment?}

No - Based on vegetation surveys, the average percentage of vegetated ground fell from $83 \%$ before restoration to $57 \%$ in 2010 because of vegetation removal during construction; however, one year 
following restoration herbaceous vegetation along the restored reach was recovering as approximately $70 \%$ of reconstructed streambanks were vegetated.

\section{2- Did the percentage of unstable streambank decrease after treatment?}

Yes - A total of $430 \mathrm{~m}$ of streambank were monitored along the restored reach to evaluate the effectiveness of restoration on streambank stability. Both erosion pins and streambank profile survey results indicate that stability increased at sub-reaches Rest-1 and Rest-2 after restoration. Stability decreased at Rest- 3 and stayed about the same at Rest-4, both of which were relatively stable before restoration. Based on these findings, $41 \%$ or $176 \mathrm{~m}$ of the reach were stable before restoration compared to $79 \%$ or $340 \mathrm{~m}$ of stable streambank following restoration. This does not take into account the unmonitored portion downstream of sub-reach Rest-4 that washed out in the year following restoration.

\section{3- Did the width to depth ratio of the channel change after treatment?}

Yes - The restoration design used for this project is most similar to a priority three restoration where the majority of work was focused in the near bank area (Doll and others 2003); however, a significant change in width to depth ratio was documented from 2009 - 2011. Average change in width to depth ratio was heavily influenced by excavation on both sides of the channel along sub-reach Rest-2/3 and subsequent bank failure at sub-reach Rest-3 resulting in further widening.

\section{4- Did restoration stop bank retreat?}

No - Before restoration, average streambank migration was $0.12 \mathrm{~m} / \mathrm{yr}$ compared to $0.05 \mathrm{~m} / \mathrm{yr}$ following restoration. Erosion pin surveys showed that bank retreat stopped at sub-reaches Rest-2 and Rest-4, slowed from $0.17 \mathrm{~m} / \mathrm{yr}$ before restoration to $0.03 \mathrm{~m} / \mathrm{yr}$ after restoration at Rest-1, but increased at Rest-3 from $0.05 \mathrm{~m} / \mathrm{yr}$ to $0.33 \mathrm{~m} / \mathrm{yr}$.

\section{5- Did restoration store sediment locally (i.e., re-build streambanks)?}

Yes - Average storage of $66.6 \mathrm{~m}^{3}$ of soil after restoration compared to average losses of $39.3 \mathrm{~m}^{3}$ before restoration indicate that restoration increased sediment storage capacity within the reach. Average migration rates and net change in sediment storage indicate that sediment was stored at sub-reaches Rest2 and Rest-4, and that no storage occurred along Rest-1 and Rest-3 following restoration. A large amount 
of variation within sub-reach Rest- 1 was evident as two sites stored sediment (i.e., $3 \mathrm{~m}^{3}$ and $12 \mathrm{~m}^{3}$ ) and two sites lost sediment (i.e., $7 \mathrm{~m}^{3}$ and $9 \mathrm{~m}^{3}$ ) resulting in a small net loss in this area.

\section{Exploring the influence of local factors on streambank stability}

For the second objective in this study, average streambank migration rate across all sites was $0.19 \mathrm{~m} / \mathrm{yr}(\mathrm{SE}=0.03)$. Twenty-six species of woody vegetation and 60 species of herbaceous vegetation were detected in riparian surveys, and the average percentage of bare ground was $23.5 \%(\mathrm{SE}=1.9)$. Average Shannon Weiner diversity of the herbaceous community was $0.68(\mathrm{SE}=0.09)$ and average streambank angle was $77^{\circ}(\mathrm{SE}=1.6)$. The average percentage of sand, silt, and clay in streambanks was $64 \%(\mathrm{SE}=2.4), 23 \%(\mathrm{SE}=1.8)$, and 13\% $(\mathrm{SE}=0.9)$, respectively.

The regression tree with the smallest cross-validation error had four splits (Figure 11). The first split was at bare ground where 25 sites with $<27 \%$ bare ground had an average migration rate of 0.076 $\mathrm{m} / \mathrm{yr}$. Sites with $\geq 27 \%$ bare ground were further separated by Shannon-Wiener diversity of woody vegetation. Sites with diversity $<0.525$ were further separated by streambank angle as two sites with streambank angle $\geq 87^{\circ}$ had an average migration rate of $0.805 \mathrm{~m} / \mathrm{yr}$. Sites with diversity $\geq 0.525$ were further separated by percentage of sand. Seven sites with $\geq 52.5 \%$ sand had an average migration rate of $0.29 \mathrm{~m} / \mathrm{yr}$ and four sites with $<52.5 \%$ sand had an average migration rate of $-0.085 \mathrm{~m} / \mathrm{yr}$. The cross validation error of this tree was 0.814 . The smallest tree with an estimated error within one SE of the minimum cross-validation error had only one split at $27 \%$ bare ground where sites with $\geq 27 \%$ bare ground had an average streambank migration rate of $-0.34 \mathrm{~m} / \mathrm{yr}$ compared to sites with $<27 \%$ bare ground, which had an average migration rate of $0.08 \mathrm{~m} / \mathrm{yr}$. The tree had a cross-validation error of 0.917 , and explained about $35 \%$ of the variation in the data. Ensuing correlation analyses showed the percentage of bare ground was significantly correlated with migration rate $\left(R^{2}=0.29 ; P<0.001\right)$ further indicating that as the percentage of bare ground increases migration rate increases (Figure 12). Stratifying these data by the percentage of sand greater or less than $70 \%$ showed that percentage of bare ground was a much 
stronger predictor of migration rate at sites with greater than $70 \%$ sand $\left(R^{2}=0.61 ; P<0.001\right)$ compared to sites with less than $70 \%$ sand $\left(R^{2}=0.17 ; P=0.05\right)$.

\section{Discussion}

Overall, these results indicate that stream restoration improved the abundance and diversity of woody vegetation, increased the percentage of bare ground, and had minimal effects on streambank stability and water quality. Continuous turbidity monitoring clearly showed that a large amount of sediment was generated by project activities. Different responses to stream restoration among subreaches indicates that local factors played a large role in restoration response as sediment loss from streambanks decreased from the pre-restoration condition in three sub-reaches, and increased in one subreach. These findings indicate that the effectiveness of a form-based approach to restoration, specifically bankfull bench construction, depends heavily on local vegetative community structure, soil composition, and pre-treatment stability, and pre-restoration assessment of these variables used to inform restoration design may be the best way to increase restoration effectiveness (Kondolf 1995; Kondolf and Micheli 1995; Kondolf 1996; Doyle and others 1999; Bash and Ryan 2002; Shields and others 2003; Gerstein and Harris 2005; Niezgoda and Johnson 2005; Alexander and Allan 2007).

\section{Vegetation communities}

Fencing and high density riparian planting resulted in increases in abundance and diversity woody vegetation communities along the restored reach. While average survival one year following restoration was low due to a combination of drought conditions in the summer after restoration and the occurrence of four flood events that exceeded the bankfull stage in spring and early summer of the year following restoration, the average abundance of woody vegetation on reconstructed streambanks remained much higher than pre-restoration levels. This was partially due to a large number of volunteer black locust and eastern sycamore that established in the year following restoration. The origin of the volunteer seedlings is unknown as they may have been in the seedbank of excavated streambanks, or may 
have been deposited following large flood events. In either case, recruitment on reconstructed streambanks demonstrates an attractive component of bankfull bench construction for facilitating revegetation of riparian corridors. Vegetation surveys before restoration indicated a large number of seedlings existed on the site before construction; therefore, transplantation of seedlings collected prerestoration and natural recruitment could eliminate a large portion of the cost of riparian planting in rural catchments where the capacity for seed dispersal is high. Also, the importance of fencing riparian areas cannot be overstated, as this was critical for protecting vegetation from trampling by cattle and herbivory by white-tailed deer (Odocoileus virginianus).

Interestingly, before construction, average woody abundance along sub-reach Rest-3 and along the reference reach was less than five individuals per survey location, yet both reaches were relatively stable as indicated by streambank profile and erosion pin surveys. This indicates that woody vegetation is not a prerequisite for streambank stability especially in areas where there is a high density of herbaceous growth. Many studies have shown that dense herbaceous growth can provide ample root reinforcement with negligible surcharge compared to large woody vegetation, which can exacerbate mass wasting if roots become undercut (Rowntree and Dollar 1999; Lyons and others 2000). Vegetation surveys at subreach Rest-3 before restoration showed that $35 \%$ of the herbaceous community was composed of two species of warm season grasses, big bluestem and Indiangrass, both of which have dense root systems extending more than $2 \mathrm{~m}$ into the substrate and are considered excellent species for stabilizing riparian soils (NRCS 2000). Removal of warm season grasses and subsequent increases in the percentage of bare ground following restoration was a consequence streambank reconstruction and has been a cause for concern in other studies of the effects of stream restoration on channel stability (Parkyn and others 2003; Sudduth and others 2011). Because bank resistance to lateral erosion depends heavily on the vigor, density, and rooting depth of riparian vegetation (Heede 1980; Ebisemiju 1994), it is no surprise that vegetation removal decreases bank resistance to erosion (Kondolf and Curry 1986; Smith and Prestegaard 2005). Geotextiles and seeding on recently excavated soils helps to increase bank resistance by reducing soil exposure; however, our data indicates that the loss of streambank vegetation at Rest-3 may have been 
a primary reason for decreases in stability at this site as the percentage of bare ground along sub-reach Rest-3 rose from $3 \%$ before restoration to $55 \%$ after project completion. Decreases in vegetation density and losses of deep rooting species of warm season grasses likely destabilized the underlying soil making this area more susceptible to erosion following construction. These results suggest that much can be learned from pre- and post-restoration monitoring of vegetation communities that can be valuable for informing restoration design and explaining project effects. Unfortunately, vegetation response to restoration is among the most under-evaluated components of stream restoration (Bash and Ryan 2002) because planting and fencing are often considered to be successful at enhancing riparian communities without data collection and analysis (Alexander and Allan 2007).

\section{Streambank stability}

The three most important factors that influenced response to restoration was 1) pre-restoration stability, 2) reductions in vegetative cover due to restoration, and 3) soil composition. Bankfull bench construction had favorable effects on streambank stability at sub-reaches Rest-1 and Rest-2 where streambank migration was effectively reduced from pre-restoration levels indicating improved stability. These sub-reaches had steep banks and relatively high percentages of bare ground before restoration, and contained higher percentages of clay and less sand than sub-reaches Rest-3 and Rest-4. Restoration had the least favorable effects at sub-reach Rest-3, which was relatively stable before restoration with bank steepness comparable to other areas within the reach, a low percentage of bare ground, and had more sand and less clay than all other sub-reaches. Sub-reach Rest-4 was also relatively stable before restoration, and erosion pin surveys indicate that sediment was stored in this area after restoration; however, photos showed large sediment losses from an un-surveyed portion of the sub-reach after restoration. Potential reasons for such varied responses to restoration may have resulted from its proximity to a point bar opposite a bend in the river maintained by rip rap, which was installed nearly 30 years ago as part of a bank stabilization measure taken by the landowner (Jack Rudolph - personal communication). Point bars are typically areas of lateral accretion where the opposite bank is a cut bank that is actively eroding and 
the point bar is a dynamic depositional area that changes appreciably from year to year (Bloom 1998). River bends heavily armored with riprap typically alter local hydraulic conditions that propagate up and downstream creating conditions for instability in nearby areas (Fischenich 2003). Thus, the proximity of this area to a heavily armored river bend likely made the potential for bank stability at this location very low.

Studies have shown that a high percentage of exposed soil (i.e., reduced vegetative cover) is associated with greater potential for erosion (Rosgen 1996; Simon and others 2003; Wynn and Mostaghimi 2006). Pre-restoration data in this study supports this finding as sub-reaches Rest-1 and Rest-2, which had the least amount of vegetative cover, were eroding at greater rates than sub-reaches Rest-3 and Rest-4 both of which had relatively high densities of vegetative cover. As previously discussed, a consequence of bankfull bench construction is vegetation removal that often results in unintentional reductions in roughness along stream corridors. This has been suggested as a cause of streambank failure in other studies of stream restoration effects where reductions in floodplain roughness from vegetation removal resulted in increases in erosion during moderate flow events that did not reach the bankfull stage (Smith and Prestegaard 2005). Regression trees in this study support such findings as the percentage of bare ground was the most important factor for predicting streambank migration rate. Streambank erosion processes are controlled by a large number of variables (e.g., pore water pressure, bulk density, near bank stress, etc.), and much work has been done to quantify relations among these variables as evidenced by the existence of a plethora of streambank erosion models (Evans and others 2003; Simon and others 2003; Van Eps and others 2004; Luppi and others 2008). Clearly, the small suite of variables used here does not account for the large number of potential causative factors; however, our results do suggest that a lack of vegetative cover is critical for predicting streambank susceptibility to erosion. Vegetative cover is valuable in this sense as an indicator of what has happened in the past where vegetation cannot establish because the occurrence of frequent changes (e.g., fluvial erosion, mass wasting), and what will happen in the future as vegetation increases root reinforcement within the soil protect streambanks from fluvial erosion (Wynn and Mostaghimi 2006). 
Soil composition, particularly the percentage of sand, is an important factor in determining the restoration potential for a given area. Although not used as a diagnostic or design tool in NCD (Rosgen 1996; Simon and others 2007; Simon and others 2008), soil composition in streambanks is a critical component of predicting channel stability (Heede 1980; Micheli and Kirchner 2002; Simon and others 2003; Simon and others 2007; Simon and others 2008). Schumm (1960) found that streambank soil composition was one of the most important factors influencing channel shape as width to depth ratio increases with the percentage of sand in the channel bed and banks as wide, shallow channels typically form in sandy soils and narrow, deep channels form in soils with higher clay content. The influence of physical soil properties, specifically the proportion of sand, on frictional resistance in streambanks has been documented in several other studies as well (Heede 1980; Micheli and Kirchner 2002; Simon and others 2003) indicating its importance in predicting river behavior and in selecting an appropriate restoration design. Simon and others (2008) specifically criticize inattention to streambank material composition in predicting channel response to disturbance as a major flaw in the Rosgen classification system and NCD. Our results support these claims as clear differences in soil composition were found at Rest-3, potentially making this area more susceptible to fluvial erosion and mass wasting following vegetation removal. Regression tree and correlation analyses in this study indicate that susceptibility to erosion from vegetation removal is much greater along streambanks with high percentages of sand, and thus should be avoided along sandy streambanks. Thus, both vegetation structure and streambank soil composition are interactively related to the restoration potential of a given area and must be considered for site selection.

A critical component of priority three restoration designs is the use of log vanes to protect newly constructed streambanks. Log vanes are designed to accomplish multiple functions including reducing shear stress on the bank toe and increasing habitat complexity for invertebrates and fish in localized areas due to creation of scour pools and increases in flow diversity (Doll and others 2003). No direct measurements of shear stress or near bank velocity was conducted in this study; however, streambank migration data indicates that vanes were effective at improving streambank stability as migration rates 
decreased at all but one survey site within $30 \mathrm{~m}$ of an upstream log vane. The only exception were survey sites located along sub-reach Rest-3, which experienced increases in migration rate at all locations as previously discussed. Macroinvertebrate community data collected from the restored reach also indicated that $\log$ vanes enhanced benthic habitat as evidenced by improvements in biotic integrity scores following restoration compared to pre-restoration conditions (Selego and others 2012).

\section{Water Quality}

Concentrations of $\mathrm{NO}_{3}, \mathrm{NH}_{3}, \mathrm{P}$, and TSS were unaffected by stream restoration in this study. The treatment may have created conditions for water quality improvement such as construction of log vanes which improved connectivity between water and benthos and through construction of bankfull benches that increased floodplain connectivity (Craig and others 2008); however, given that the Cacapon River is a large third order stream and that the restored reach is $<1 \mathrm{~km}$ in length, it is not surprising that no detectable change in water quality occurred (Rutherfurd and others 2004). Detectable improvement in water quality via restoration is more likely to be achieved with strategies that increase transient storage and thus nutrient uptake rates within the reach (Bukaveckas 2007) or by restoration initiatives implemented at larger scales (Roni and others 2002). Continuous monitoring of nutrient levels may have also improved the ability to detect differences in these water quality variables as studies have shown that quantifying restoration effects is difficult because sample sizes have to be very high to detect a treatment effect (Rutherfurd and others 2004). Furthermore, reach-scale restoration strategies are not typically designed to improve in-stream water quality as watershed-scale land management strategies such as best management practices (BMPs) are more likely to be successful at reducing problem pollutants.

Streambank stabilization should complement large-scale strategies quite well by reducing channel sources of nutrients and sediment (Palmer and others 2003; Craig and others 2008). Water quality improvement via restoration in this study is better represented with results of repeated streambank profile surveys, which indicate increased sediment storage following restoration which effectively decreased sediment and 
nutrient inputs to the Cacapon River as $93 \mathrm{~m}^{3}$ of sediment $\left(15.9 \mathrm{~m}^{3}\right.$ of $\mathrm{N} ; 2.5 \mathrm{~m}^{3}$ of $\left.\mathrm{P}\right)$ was prevented from entering the Cacapon after restoration (2010 - 2011) compared to the year before restoration (2009 2010) when $39.2 \mathrm{~m}^{3}$ of sediment $\left(4.4 \mathrm{~m}^{3}\right.$ of $\mathrm{N} ; 0.99 \mathrm{~m}^{3}$ of $\left.\mathrm{P}\right)$ was lost from the reach.

Continuous monitoring in this study indicates that the restored reach was producing a small amount of sediment before and after restoration, but was a major sediment source during the active construction phase. Both before and after restoration, depth was decreasing following a flow event when downstream turbidity spiked. This may indicate that a sediment pulse originated from within the reach during these periods. Mechanisms controlling streambank retreat such as translational and cantilever failures are more common during the falling limb of a hydrograph due to reductions in stabilizing positive pore water pressure and increases in surcharge due to streambank saturation (Luppi and others 2008). Continuous monitoring clearly indicated that construction increased turbidity for an extended period, which is concerning given that a primary goal was to reduce channel sources of sediment. A reduction in $\%$ EPT taxa from samples collected during the active construction phase indicates that increased turbidity may have induced drift of many taxa in the restoration reach; however, by August 2010, \%EPT taxa had increased to pre-restoration levels indicating quick recovery following restoration (Selego and others 2012). These results suggest that continuous monitoring upstream and downstream of a restored reach can be used to identify the timing and magnitude of an erosion event occurring within the reach and is likely an underused monitoring tool for restoration. While the initial costs of this approach are expensive and consistent maintenance is required (e.g., repeated calibrations), increased availability of multiparameter probes that measure turbidity, phosphorus, and several forms of nitrogen may reduce the cost of traditional restoration evaluation via grab sampling, which can cost more than actual restoration if designed appropriately (Rutherfurd and others 2004).

\section{Conclusions and Management Implications}

Even amidst controversy regarding effectiveness (Kondolf and Micheli 1995; Kondolf 1996; Kondolf 1998; Kondolf and others 2001; Palmer and others 2003; Smith and Prestegaard 2005; Wohl and 
others 2005; Louhi and others 2011; Sudduth and others 2011), NCD is the primary restoration methodology endorsed by governmental agencies in the U.S. (Palmer and Bernhardt 2006; Lave and others 2010). Many academically trained scientists and engineers who have spent their careers studying streambank stability and river behavior argue that NCD is not an appropriate restoration design due to its simplicity and over-interventionist approach and the economic and safety implications that hang in the balance (Kondolf and Micheli 1995; Kondolf 1998; Doyle and others 1999; Kondolf and others 2001; Bernhardt and others 2005). Therefore, to help gage success of this multifaceted restoration approach, we analyzed riparian vegetation, streambank stability, and water quality data before and after stream restoration and determined that, overall, restoration enhanced woody vegetation communities, but had little short-term effect on streambank stability and water quality; however, pre-restoration data collected from the reach showed important differences in local factors among sub-reaches that impacted the restoration potential of each area.

The most important local factors that determined success or failure of streambank stabilization treatments appeared to be related to pre-treatment stability, vegetative cover, and soil composition that could only be accounted for using pre-restoration data collection and process measurements. The "form versus process" debate among stream restorationists and scientists often deem NCD and process based restoration as mutually exclusive (Kondolf and others 2001; Simon and others 2007; Simon and others 2008; Rosgen 2008; Lave and others 2010); however, our results indicate that process measurements prior to restoration design could facilitate better use of valuable NCD techniques. For example, the bankfull bench or priority three restoration (Doll and others 2003) clearly has merit for streambank stabilization and riparian enhancement; however, site selection for this approach is extremely important as demonstrated by increased instability resulting from bankfull bench construction in some areas. The restoration potential of a reach and within a reach is an important factor that must considered for increased success of NCD. Determining restoration potential must rely more heavily on process measurements via process models or pre-project data collection (Doyle and others 1999; Wohl and others 2005) where even short-term monitoring can be invaluable. Although time and money are often limiting 
factors for monitoring (Bash and Ryan 2002), management strategies developed using data from potential restoration sites will aid in assessment of local variability in processes like streambank migration facilitating improved river management regardless of the techniques used.

\section{Acknowledgments}

The authors thank the National Fish and Wildlife Foundation, the Chesapeake Bay Trust, the National Oceanic and Atmospheric Administration, FishAmerica Foundation, Canaan Valley Institute, Cacapon and Lost Rivers Land Trust, and the West Virginia University (WVU) Environmental Research Center for funding and logistic support. Also, thanks to the local landowners, Joe Frye, Joshua Frye, Sandy White, and Jack Rudolph for participating in this project, and to Dr. George Merovich, Dr. Michael Strager, Dr. Steven Kite, Walter Veselka, Steven Selego, Kathryn McCoard, Gabriel Strain, Jeremy Mizel, Cameron Eddy, Will Ravenscroft, and Jerry Yates for additional assistance.

\section{Literature Cited}

Alexander GG, Allan JD (2007) Ecological success in stream restoration: case studies from the midwestern United States. Environmental Management 40:245-255

Antweiler RC, Taylor HE (2008) Evaluation of statistical treatments of left-censored environmental data using coincident uncensored data sets: I. Summary statistics. Environmental Science and Technology 42:3272-3738

Bash JS, Ryan CM (2002) Stream restoration and enhancement projects: is anyone monitoring? Environmental Management 29:877-885

Bernhardt E, Palmer M, Allan J, Alexander G, Barnas K, Brooks S, Carr J, Clayton S, Dahm C, FollstadShah J, Galat D, Gloss S, Goodwin P, Hart D, Hassett B, Jenkinson R, Katz S, Kondolf G, Lake PS, Lave R, Meyer J, O’Donnell T, Pagano L, Powell B, Sudduth E (2005) Synthesizing US river restoration efforts. Science 308:636-637 
Bloom AL (1998) Geomorphology: A Systematic Analysis of Late Cenozoic Landforms $3^{\text {rd }}$ edn, Prentice Hall, New Jersey

Bukaveckas PA (2007) Effects of channel restoration on water velocity, transient storage, and nutrient uptake in a channelized stream. Environmental Science and Technology 41:1570-1576

Clesceri LS, Eaton AD, Greenberg AE, Franson MH (1996) Standard Methods for the Examination of Water and Wastewater $20^{\text {th }}$ edn. American Public Health Association, Washington D.C.

Connell J H (1978) Diversity in tropical rain forests and coral reefs. Science 199:1302-1310

Constantz G, Ailes N, Malakoff D (1995) Portrait of a river: the ecological baseline of the Cacapon River. Cacapon Institute. http://www.cacaponinstitute.org. Accessed 2009 March 21

Craig LS, Palmer MA, Richardson DC, Filoso S, Bernhardt ES, Bledsoe BP, Doyle MW, Groffman PM, Hasset BA, Kaushal SS, Mayer PM, Smith SM, Wilcock PR (2008) Stream restoration strategies for reducing nitrogen loads. Frontiers of Ecology and the Environment 6:529-538

De'ath G, Fabricius KE (2000) Classification and regression trees: a powerful yet simple technique for ecological data analysis. Ecology 81:3178-3192

Doll BA, Grabow GL, Hall KR, Halley J, Harman WA, Jennings GD, Wise DE (2003) Stream Restoration: A Natural Channel Design Handbook. Prepared by the North Carolina Stream Restoration Institute and the North Carolina Sea Grant.

Downs PW, Skinner KS, Kondolf GM (2002) Rivers and Streams. In: Perrow MR, Davy AJ (eds) Handbook of Ecological Restoration vol 2: Restoration in Practice. Cambridge, NY, pp 267-296

Doyle MW, Miller DE, Harbor JM (1999) Should river restoration be based on classification schemes or process models? Insights from the history of geomorphology. Proceedings of the International Conference on Water Resources Engineering, Seattle, Washington. http://www.globalrestorationnetwork.org/uploads/files/LiteratureAttachments/466_should-riverrestoration-be-based-on-classification-schemes-or-process-models.pdf. Accessed 16 July 2010 
Ebisemiju F (1994) The sinuosity of alluvial river channels in the seasonally wet tropical environment:

Case study of River Elmi, South Western Nigeria. Catena 24:13-25

Evans BM, Sheeder SA, Lehning DW (2003) A spatial technique for estimating streambank erosion based on watershed characteristics. Journal of Spatial Hydrology 3:1-13

Fischenich, JC (2003) Effects of riprap on riverine and riparian ecosystems, ERDC/EL TR-03-4, U.S. Army Engineer Research andDevelopment Center, Vicksburg, MS

Gerstein JM, Harris RR (2005) Protocol for monitoring the effectiveness of bank stabilization restoration. University of California, Center for Forestry, Berkeley, CA. 24 pp

Gillies N (2009) Cacapon Institute. High View, WV. http://www.cacaponinstitute.org/index.htm. Accessed on 21 September 2010

Harrelson CC, Rawlins CL, Potyondy JP (1994) Stream channel reference sites: an illustrated guide to field technique. USDA Technical Report RM-245

Hasset B, Palmer M, Bernhardt E, Smith S, Carr J, Hart D (2005) Restoring watersheds project by project: trends in Chesapeake Bay tributary restoration. Frontiers in Ecological Environments 3:259-267

Heede BH (1980) Stream dynamics: an overview for land managers. USDA Forest Service, Rocky Mountain Forest and Range Experiment Station, General Technical Report RM-72

Hey RD (2006) Fluvial geomorphological methodology for natural stable channel design. Journal of the American Water Resources Association 42:357-374

Hupp CR, Richter JM, Peet RK, Townsend PA (2009) Bank erosion along the dam-regulated lower Roanoke River, North Carolina. Management and Restoration of Fluvial Systems with Broad Historical Changes and Human Impacts: Geological Society of America Special Paper 451:97108

Keller JM, Gee GW (2005) Comparison of American Society of Testing Materials and Soil Science Society of America hydrometer methods for particle-size analysis. Soil Society of America Journal 4:1094-1100 
Kondolf GM, Curry RR (1986) Channel erosion along the Carmel River, Monterey County, California. Earth Surface Processes and Landforms 11:307-319

Kondolf GM (1995) Five elements for effective evaluation of stream restoration. Restoration Ecology 3:133-136

Kondolf GM, Micheli ER (1995) Evaluating stream restoration projects. Environmental Management 19:1-15

Kondolf GM (1996) A cross section of stream channel restoration. Journal of Soil and Water Conservation 51:119-125

Kondolf GM (1998) Lessons learned from river restoration projects in California. Aquatic Conservation: Marine and Freshwater Resources 8:39-52

Kondolf GM, Smeltzer MW, Railsback SF (2001) Design and performance of a channel reconstruction project in a coastal California gravel-bed stream. Environmental Management 28:761-776

Langendoen EJ, Simon A (2008) Modelling the evolution of incised streams II: stream bank erosion. Journal of Hydraulic Engineering ASCE 134:905-915

Lave R, Doyle M, Robertson M (2010) Privatizing stream restoration in the US. Social Studies of Science 40:677-703

Louhi, P H, Mykra R, Paavola A, Huusko T, Vehanen, A Ma ki-Peta, Muotka T (2011) Twenty years of stream restoration in Finland: little response by benthic macroinvertebrate communities. Ecological Applications 21:1950-1961

Luppi L, Rinaldi M, Teruggi LB, Darby SE, Nardi L (2008) Monitoring and numerical modeling of riverbank erosion processes: a case study along the Cecina River (central Italy). Earth Surface Processes and Landforms. DOI 10.1002/esp.1754

Lyons JL, Trimble SW, Paine LK (2000) Grass versus trees: managing riparian areas to benefit streams of central North America. Journal of the American Water Resources Association 36:919-930

McGeehan SL, Naylor DV (1988) Automated instrumental analysis of carbon and nitrogen in plant and soil samples. Communication in Soil Science and Plant Analysis 19:493-505 
Micheli ER, Kirchner JW (2002) Effects of wet meadow riparian vegetation on streambank erosion. 2. Measurements of vegetated bank strength and consequences for failure mechanics. Earth Surface Processes and Landforms 27:687-697

Natural Resources Conservation Service (2000) Grazing fact sheets. ftp://ftpfc.sc.egov.usda.gov/IL/grazing/WS-BgBlue.pdf. Accessed on 8 March 2012

Niezgoda SL, Johnson PA (2005) Improving the urban stream restoration effort: identifying critical form and processes relationships. Environmental Management 35:579-592

Olsen SR, Sommers LE (1982) Phosphorus In Page AL (ed) Methods of soil analysis, part 2, Agronomy Monograph, 2nd edn. ASA and SSSA, WI pp 400-430

Olson-Rutz KM, Marlow CB (1992) Analysis and interpretation of stream channel cross-sectional data. North American Journal of Fisheries Management 12:22-61

Palmer MA, Hart DD, Allan JD, Bernhardt E (2003) Bridging engineering, ecological, and geomorphic science to enhance river restoration: local and national efforts. Proceedings of a National Symposium of Urban and Rural Stream Protection and Restoration, EWRI World Water and Environmental Congress. American Society for Civil Engineers, Reston, Va. http://www.palmerlab.umd.edu/docs/Palmer_et_al_World_Water_Congress_final_Feb_03.pdf. Accessed 8 March 2010

Palmer MA, Bernhardt ES (2006) Hydroecology and river restoration: ripe for research and synthesis. Water Resources Research 42:1-4

Parkyn SM, Davies-Colley RJ, Halliday NJ, Costley KJ, Croker GF (2003) Planted riparian buffer zones in New Zealand: do they live up to expectations? Restoration Ecology 11:436-437

Pitchford JL (2012) Stream restoration: site selection and project evaluation. Dissertation, West Virginia University

R Development Core Team (2011) R: A language and environment for statistical computing, reference index version 2.12.1. R Foundation for Statistical Computing, Vienna, Austria. ISBN 3-900051$07-0$ 
Rentch JS, Fortney RH, Stephenson SL, Adams HS, Grafton WN, Anderson JT (2005) Vegetation - site relationships of roadside plant communities in West Virginia, USA. Journal of Applied Ecology 42:129-138

Roni P, Beechie TJ, Bilby RE, Leonetti FE, Pollock MM, Pess GR (2002) A review of stream restoration techniques and a hierarchical strategy for prioritizing restoration in pacific northwest watersheds. North American Journal of Fisheries Management 22:1-20

Rosgen D (1996) Applied River Morphology $2^{\text {nd }}$ edn. Wildland Hydrology, Colorado

Rosgen, D (2008) Reply to discussion "Critical Evaluation of how the Rosgen classification and associated 'Natural Channel Design' methods fail to integrate and quantify fluvial process and channel responses" by A Simon, M. Doyle, M. Kondolf, F.D. Shields Jr., B. Rhoads, and M. McPhillips. Journal of the American Water Resources Association 44:782-789

Rowntree KM, Dollar SJ (1999) Vegetation controls on channel stability in the Bell River, Eastern Cape, South Africa. Earth Processes and Landforms 24:127-134

Rutherfurd I, Ladson AR, Stewardson MJ (2004) Evaluating stream rehabilitation projects: reasons not to, and approaches if you have to. Australian Journal of Water Resources 8:57-68

Schumm SA (1960) The shape of alluvial channels in relation to sediment type: US Geological Survey Prof Paper 352-B, pp 17-30

Selego SM (2011) Fish and aquatic macroinvertebrate communities in the Cacapon River, West Virginia. Thesis, West Virginia University

Selego SM, Rose CL, Merovich GT, Welsh SA, Anderson JT (2012) Community-level response of fishes and aquatic macroinvertebrates to stream restoration in a third-order tributary of the Potomac River, USA. International Journal of Ecology. Doi: 10.1155/2012/75364

Shields FD, Copeland RR, Klingeman PC, Doyle MW, Simon A (2003) Design for stream restoration. Journal of Hydraulic Engineering 129:575-584 
Simon A, Collison AJC, Layzell A (2003) Incorporating bank-toe erosion by hydraulic shear into the ARS bank stability model: Missouri River, eastern Montana. Proceedings of the First Interagency Conference on Research in the Watersheds, USDA ARS, Benson, AZ. pp 70-76

Simon A, Doyle M, Kondolf M, Shields FD, Rhoads B, McPhillips M (2007) Critical evaluation of how the Rosgen classification and associated 'Natural Channel Design' methods fail to integrate and quantify fluvial processes and channel response. Journal of the American Water Resources Association 43:1117-1131

Simon A, Doyle M, Kondolf M, Shields FD, Rhoads B, McPhillips M (2008) Reply to discussion by Dave Rosgen "Critical evaluation of how the Rosgen classification and associated 'Natural Channel Design' methods fail to integrate and quantify fluvial processes and channel responses". Journal of The American Water Resources Association 44:782-792

Smith EP (2002) BACI design In: El-Shaarawi AH, Piegorsch WW (eds.) Encyclopedia of Environmetrics ISBN 0471 899976, Wiley, Chichester pp 141-148

Smith SM, Prestegaard KL (2005) Hydraulic performance of a morphology-based stream channel design. Water Resources Research 41:1-17

Strager MP, Anderson JT, Osbourne JD, Fortney R (2011) A three-tiered framework to select, prioritize, and evaluate potential wetland and stream mitigation banking sites. Wetlands Ecology and Management 19:1-18

Sudduth EB, Hassett BA, Cada P, and Bernhardt ES (2011) Testing the field of dreams hypothesis: functional responses to urbanization and restoration in stream ecosystems. Ecological Applications 21:1972-1988

U.S. Geological Survey Gauging Station. Great Cacapon, WV. www.waterdata.usgs.gov/usa/nwis/uv?site_no=01611500. Accessed on 23 August 2011.

Van Eps MA, Formica SJ, Morris TL, Beck JM, Cotter AS (2004) Annual sediment loads from streambank erosion in the White Fork watershed. Measurement 303(d). http://streams.osu.edu/streams_pdf/vaneps.pdf. Accessed 15 November 2009 
West Virginia Geological and Economic Survey (2011) Mont Chateau Research Center. http://www.wvgs.wvnet.edu/. Accessed 8 March 2011

Wohl E, Angermeier PL, Bledsoe B, Kondolf GM, MacDonnel L, Merrit DM, Palmer MA, Poff NL, Tarboton D (2005) River restoration. Water Resources Research 41:1-12

Wolman MG, Miller JP (1960) Magnitude and frequency of forces in geomorphic processes. Journal of Geology 68: 54-74

Wynn T, Mostaghimi S (2006) The effects of vegetation and soil type on streambank erosion, southwestern Virginia, USA. Journal of the American Water Resources Association 2:69-82

YSI (2010) Calibration, maintenance and troubleshooting tips: YSI 6 Series Sondes \& Sensors. Ohio, 39p 
Table 1 Average measures of channel dimension, pattern, and profile in 2009 for a reach of the Cacapon River, West Virginia selected for stream restoration.

\begin{tabular}{|c|c|c|c|c|c|c|c|c|}
\hline \multicolumn{4}{|l|}{ Metric } & \multicolumn{3}{|l|}{ Mean } & \multicolumn{2}{|c|}{$\mathrm{E}$} \\
\hline \multicolumn{4}{|c|}{ Bankfull cross-sectional area $\left(\mathrm{m}^{2}\right)$} & \multicolumn{3}{|l|}{69} & \multicolumn{2}{|c|}{3.4} \\
\hline \multicolumn{4}{|c|}{ Entrenchment ratio } & \multicolumn{3}{|l|}{$>2.2^{\mathrm{a}}$} & \multicolumn{2}{|c|}{-} \\
\hline \multicolumn{4}{|c|}{ Width/depth } & \multicolumn{3}{|l|}{21} & \multicolumn{2}{|c|}{1.6} \\
\hline \multicolumn{4}{|l|}{ Sinuosity } & \multicolumn{3}{|l|}{1.6} & \multicolumn{2}{|c|}{-} \\
\hline \multicolumn{4}{|l|}{ Slope } & \multicolumn{3}{|l|}{$0.3 \%$} & \multicolumn{2}{|c|}{-} \\
\hline \multicolumn{4}{|c|}{ BEHI score ${ }^{b}$} & \multicolumn{3}{|c|}{29.3 (High Erosion Potential) } & \multicolumn{2}{|c|}{1.8} \\
\hline \multicolumn{4}{|c|}{ Bank height (m) } & \multicolumn{3}{|l|}{2.5} & \multicolumn{2}{|c|}{0.2} \\
\hline \multicolumn{4}{|c|}{ Bankfull/bank height } & \multicolumn{3}{|l|}{1.72} & \multicolumn{2}{|c|}{0.1} \\
\hline \multicolumn{4}{|c|}{ Bank angle } & \multicolumn{3}{|l|}{$76^{\circ}$} & \multicolumn{2}{|c|}{1.6} \\
\hline \multicolumn{4}{|c|}{ Vegetative cover } & \multicolumn{3}{|l|}{$57 \%$} & \multicolumn{2}{|c|}{11} \\
\hline \multicolumn{9}{|c|}{$\begin{array}{l}{ }^{\text {a}} \text { Entrenchment ratios are extremely high, indicating only minor entrenchment, because the width of the floodprone } \\
\text { area (i.e., width at two times bankfull depth) would approximate the width of the valley, which is }>1 \mathrm{~km} \text { in the } \\
\text { selected reach. } \\
\text { b Bank Erosion Hazard Index (BEHI) is a commonly used index of streambank erosion potential in restoration } \\
\text { planning and design. }\end{array}$} \\
\hline \multicolumn{9}{|c|}{$\begin{array}{l}\text { Table } 2 \text { Cross-section measures from a restored reach of the Cacapon River, West Virginia. } \Delta \text { W/D } \\
\text { is the measured change in width to depth ratio, }|\Delta \mathrm{A} \%| \text { is the absolute value of the percent change in } \\
\text { stream cross-sectional area, and } \mathrm{G} \text { diff is the difference in Gini coefficients during the specified time } \\
\text { period. Standard error for each variable is shown in parentheses. }\end{array}$} \\
\hline Reach & Reps & $\begin{array}{l}\Delta \mathrm{W} / \mathrm{D} \\
(09-10)\end{array}$ & & & $\begin{array}{l}\text { G diff } \\
(09-10)\end{array}$ & $\begin{array}{l}\Delta \mathrm{W} / \mathrm{D} \\
(09-11)\end{array}$ & $\begin{array}{l}\Delta \mathrm{A} \% \mid \\
(09-11) \\
\end{array}$ & $\begin{array}{l}\text { G diff } \\
(09-11)\end{array}$ \\
\hline Rest-1 & 4 & $0.53(0.4)$ & & $(0.6)$ & $0.003(0.02)$ & $0.99(0.1)$ & $8.05(1.1)$ & $0.054(0.03)$ \\
\hline Rest- $2 / 3$ & 3 & $1.43(0.9)$ & & $5(3.2)$ & $0.016(0.01)$ & $2.32(1.2)$ & $9.50(2.8)$ & $0.014(0.02)$ \\
\hline Rest-4 & 3 & $0.24(0.5)$ & & $(3.2)$ & $-0.024(0.02)$ & $0.36(1.1)$ & $10.1(1.3)$ & $-0.015(0.01)$ \\
\hline Total & 10 & $0.71(0.3)$ & & (1.7) & $-0.001(0.01)$ & $1.20(0.5)$ & $9.09(0.92)$ & $0.021(0.02)$ \\
\hline
\end{tabular}

Table 3 Estimates of net change in sediment storage derived from repeated streambank profile surveys along a restored reach of the Cacapon River, West Virginia. Standard error for each variable is shown in parentheses. If only one profile survey was conducted due to loss of benchmarks between surveys, no standard error could be calculated.

\begin{tabular}{lllll}
\hline Reach & Pre- reps & Post-reps & $2009-2010\left(\mathrm{~m}^{3}\right)$ & $2010-2011\left(\mathrm{~m}^{3}\right)$ \\
\hline Rest-1 & 3 & 4 & $-41.1(9.6)$ & $-4.9(5.4)$ \\
Rest-2 & 1 & 2 & -2.8 & $-4.3(3.3)$ \\
Rest-3 & 3 & 2 & $2.4(0.5)$ & $-63.3(12.6)$ \\
Rest-4 & 1 & 1 & 6.9 & 139.1 \\
Total & 8 & 9 & $-39.2(10.7)$ & $66.6(43.1)$ \\
\hline
\end{tabular}


Table 4 The percentage of nitrogen $(\mathrm{N})$ in soil samples collected from a reach selected for stream restoration on the Cacapon River, West Virginia. Also shown is an estimate of total sediment and N lost (-) or gained from each site before and (2009-2010) and after restoration (2010-2011) using percent $\mathrm{N}$ from soil samples. Standard error for percent $\mathrm{N}$ is shown in parentheses.

\begin{tabular}{|c|c|c|c|c|c|}
\hline \multirow[b]{2}{*}{ Site } & \multirow[b]{2}{*}{$\% \mathrm{~N}$} & \multicolumn{2}{|c|}{ Pre-Restoration } & \multicolumn{2}{|c|}{ Post- Restoration } \\
\hline & & Sediment $\left(\mathrm{m}^{3}\right)$ & $\mathrm{N}\left(\mathrm{m}^{3}\right)$ & Sediment $\left(\mathrm{m}^{3}\right)$ & $\mathrm{N}\left(\mathrm{m}^{3}\right)$ \\
\hline Rest-1 & $12(2.1)$ & -41.1 & -4.8 & -4.9 & -0.6 \\
\hline Rest-2 & $12(1.7)$ & -2.8 & -0.3 & -4.3 & -0.5 \\
\hline Rest-3 & $10(0.1)$ & -2.4 & -0.2 & -63.3 & -7.3 \\
\hline Rest-4 & $14(0.1)$ & 6.9 & 1.0 & 139.1 & 19.9 \\
\hline Total & $12(0.1)$ & -39.2 & -4.4 & +66.6 & 11.5 \\
\hline
\end{tabular}

Table 5 The percentage of phosphorus $(\mathrm{P})$ in soil samples collected from a reach selected for stream restoration on the Cacapon River, West Virginia. Also shown is an estimate of total sediment and P lost (-) or gained from each site before and (2009-2010) and after restoration (2010-2011) using percent $P$ from soil samples. Standard error for percent $\mathrm{P}$ is shown in parentheses.

\begin{tabular}{|c|c|c|c|c|c|}
\hline \multirow[b]{2}{*}{ Site } & \multirow[b]{2}{*}{$\% \mathrm{P}$} & \multicolumn{2}{|c|}{ Pre-Restoration } & \multicolumn{2}{|c|}{ Post- Restoration } \\
\hline & & Sediment $\left(\mathrm{m}^{3}\right)$ & $\mathrm{P}\left(\mathrm{m}^{3}\right)$ & Sediment $\left(\mathrm{m}^{3}\right)$ & $\mathrm{P}\left(\mathrm{m}^{3}\right)$ \\
\hline Rest-1 & $3(0.3)$ & -41.1 & -1.03 & -4.9 & -0.12 \\
\hline Rest-2 & $2(0.2)$ & -2.8 & -0.06 & -4.3 & -0.09 \\
\hline Rest-3 & $2(0.1)$ & -2.4 & -0.05 & -63.3 & -1.45 \\
\hline Rest-4 & $2(0.0)$ & 6.9 & 0.15 & 139.1 & 3.19 \\
\hline Total & $2(0.1)$ & -39.2 & -0.99 & 66.6 & 1.52 \\
\hline
\end{tabular}




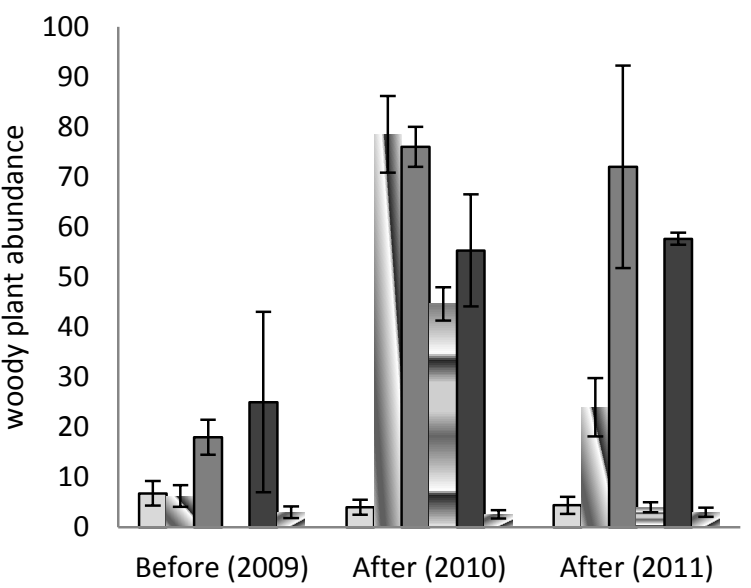

c)

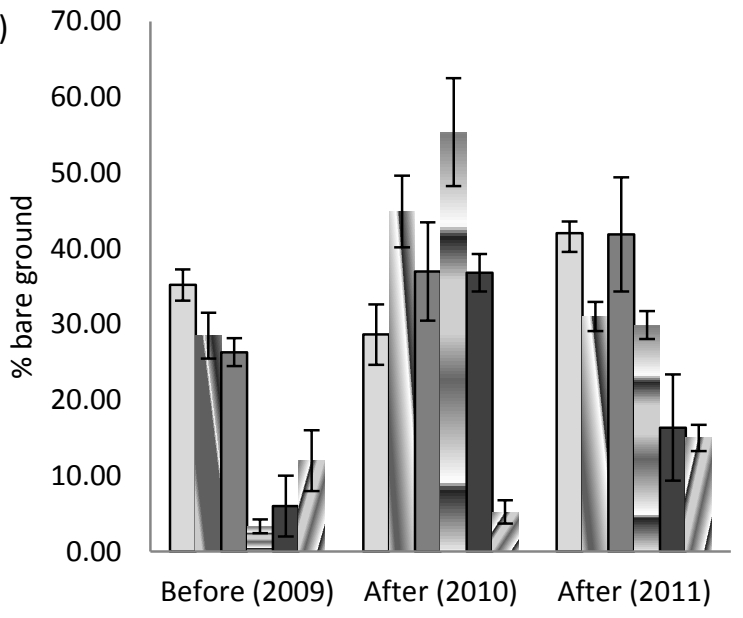

b)

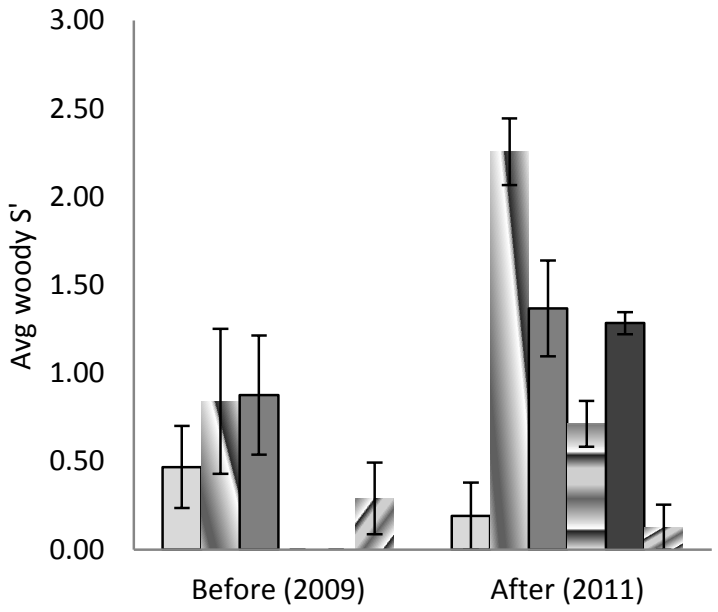

$\square$ Control

$\triangle$ Rest-1

$\square$ Rest-2

豆est-3

$\square$ Rest-4

7 Reference

Fig. 1 Average a) abundance of woody vegetation, b) Shannon-Wiener diversity of woody vegetation $\left(H^{\prime}\right)$, and c) percentage of bare ground in riparian areas along restored sub-reaches compared to a control and reference reach before and after stream restoration in the Cacapon River Watershed, West Virginia. Woody abundance and the percentage of bare ground are shown for all three years of monitoring. 


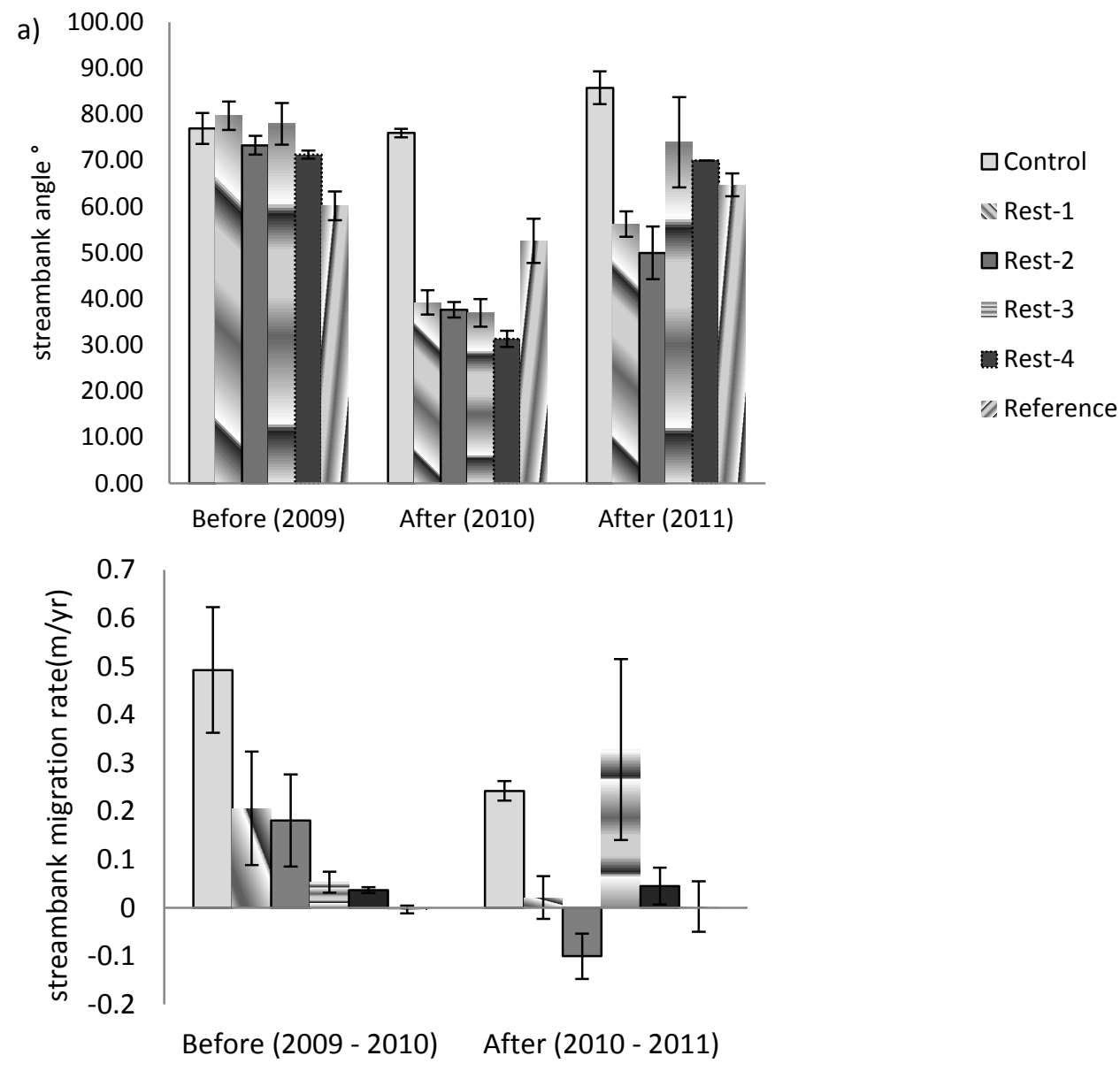

Fig. 2 Average a) streambank angle and b) streambank migration rate ( $\mathrm{m} / \mathrm{yr})$ along restored sub-reaches compared to a control and reference reach before and after stream restoration in the Cacapon River Watershed, West Virginia. Negative migration rates indicate aggradation. Streambank angle is shown for all three years of monitoring. 

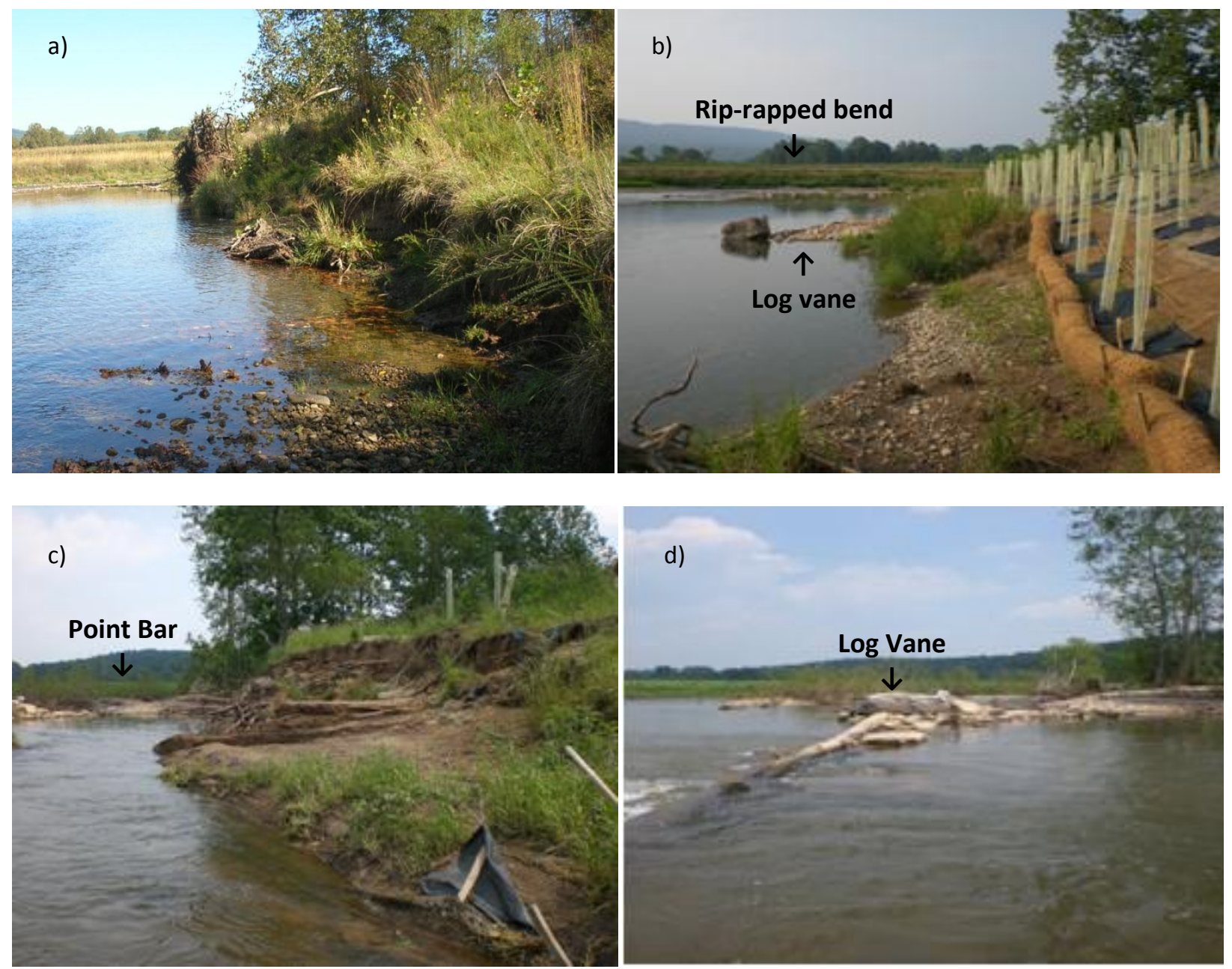

Fig. 3 Photos looking downstream from Rest-4 along a restored reach of the Cacapon River, West Virginia in (a) 2009 before restoration, (b) 2010 after construction of a bankfull bench and log vanes, and (c) 2011 one year after restoration was completed. The proximity of this area to a point bar opposite a rip rap meander bend may have contributed to bank failure as (d) a large portion of the reconstructed streambank washed out in the year following restoration leaving a log vane in the channel following four $1.5-2.5$ year flood events in spring and early summer of 2011. 

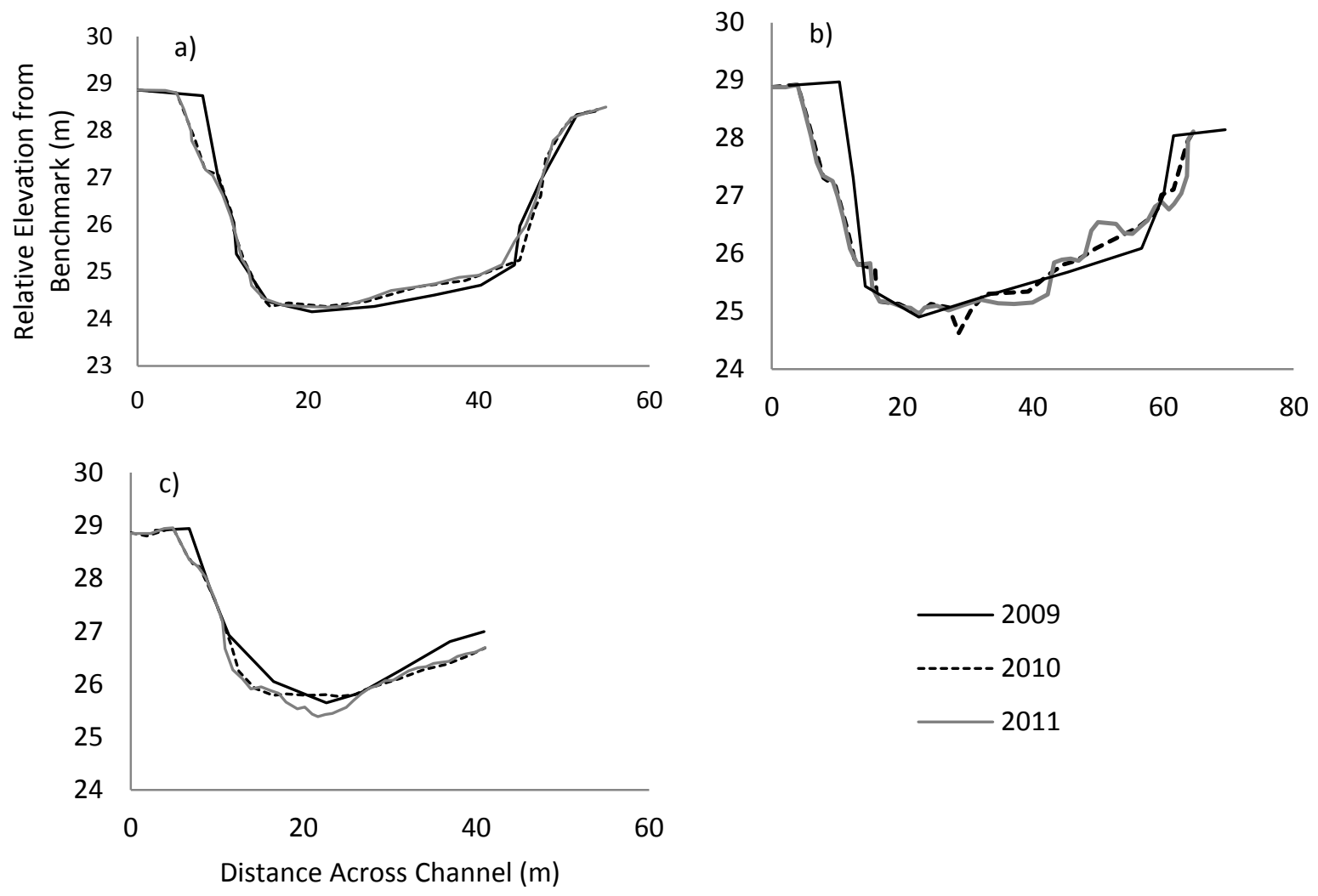

Fig. 4 Representative cross-sections at each of three streambank sub-reaches along a $750 \mathrm{~m}$ restored reach of the Cacapon River one year before restoration (6/2009), two weeks following restoration (7/2010), and 11 months after restoration (6/2011). Figure a) shows a representative cross section from Rest-1, figure b) from Rest-2/3, and figure c) from Rest-4. 


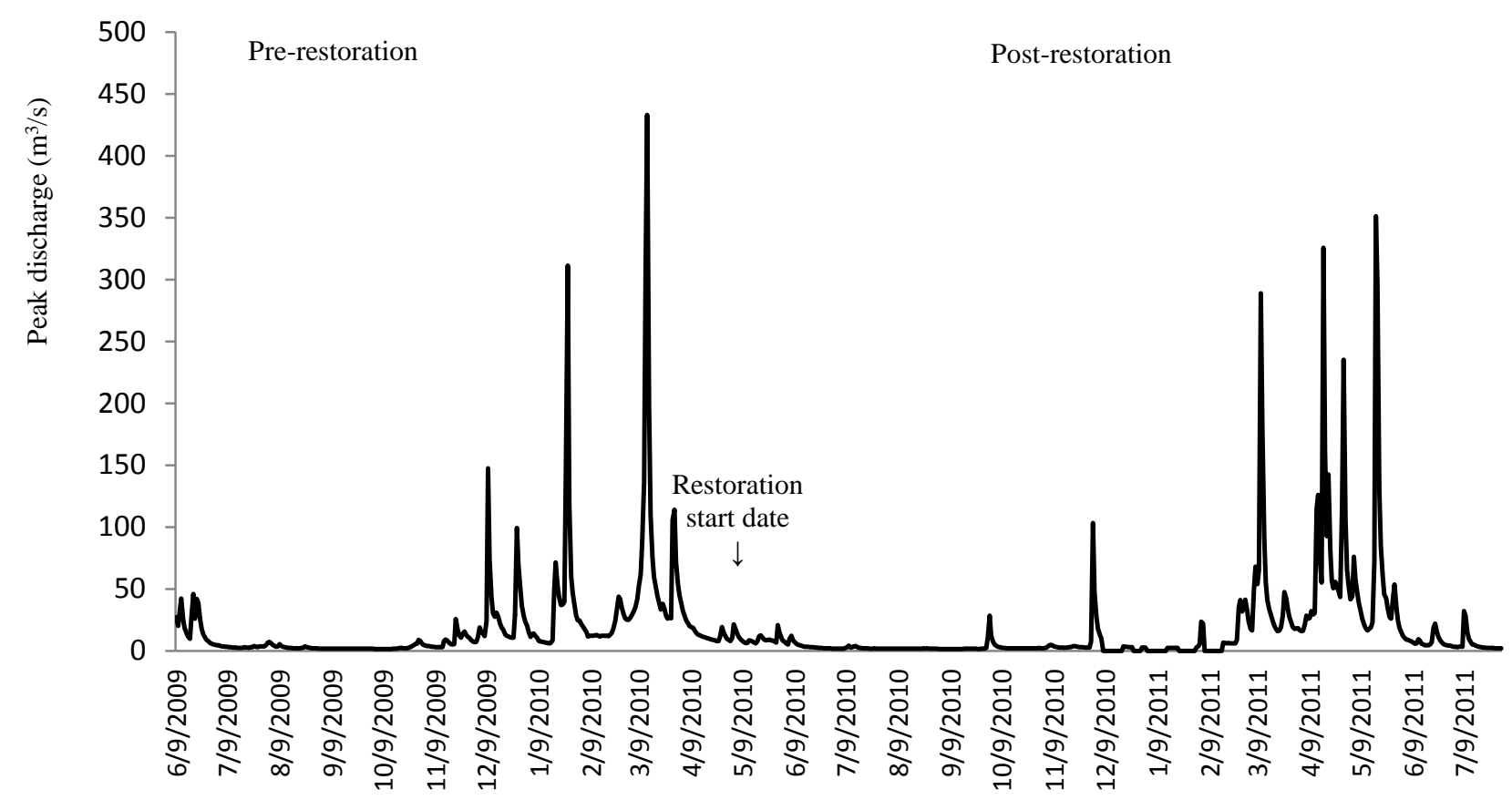

Fig. 5 A hydrograph of peak discharge from the Cacapon River near Great Cacapon, West Virginia from June 2009 - July 2011. The approximate start date of restoration activity was 5/10/2010. Based on a calculated bankfull discharge of $110 \mathrm{~m}^{3} / \mathrm{s}$, four distinct bankfull events occurred pre-restoration and postrestoration. The largest magnitude event occurred pre-restoration at $440 \mathrm{~m}^{3} / \mathrm{s}$. 

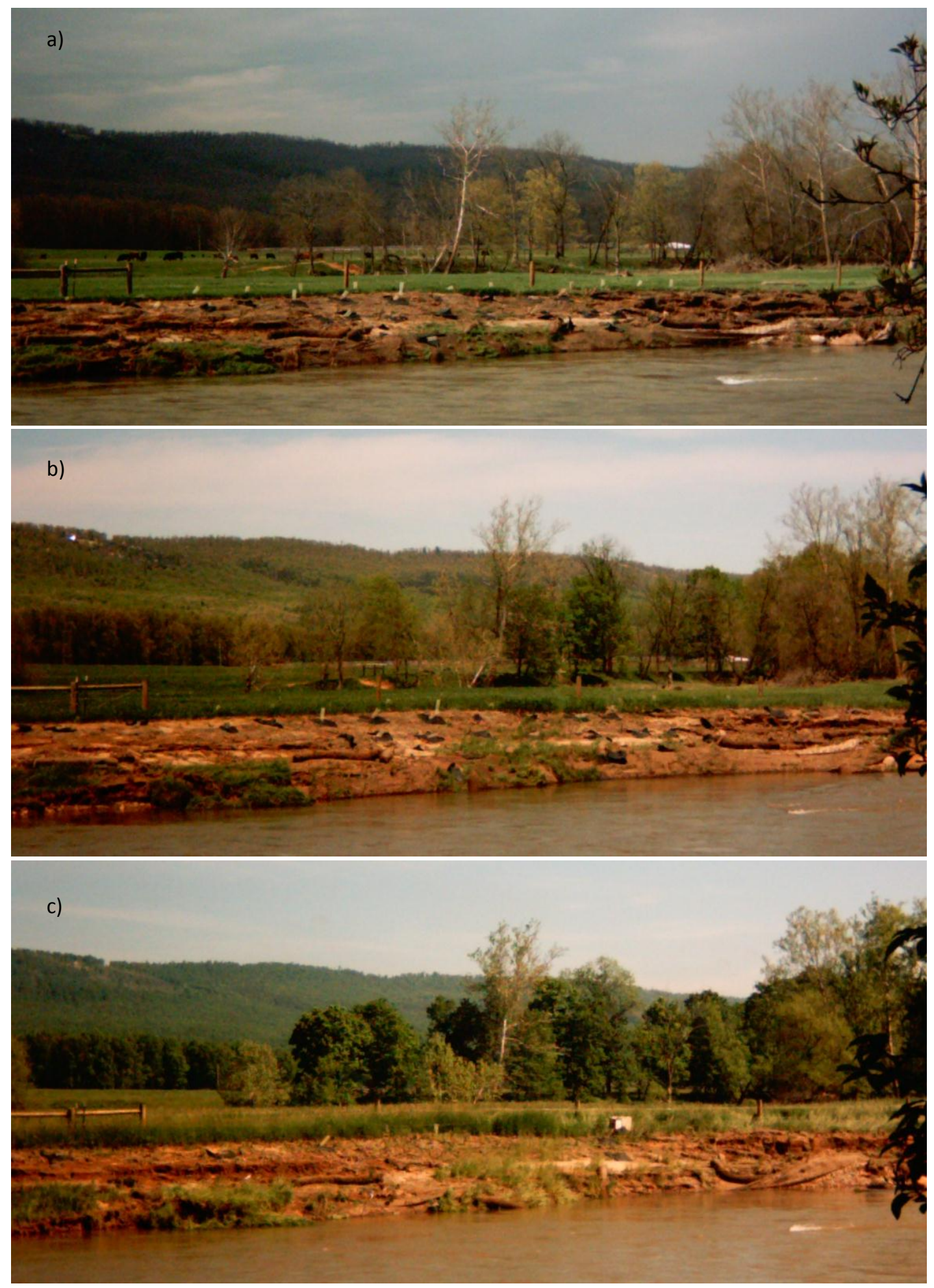

Fig. 6 Photos taken of sub-reach Rest-3 in the spring following stream restoration (2011) after floodwaters receded from a) $330 \mathrm{~m}^{3} / \mathrm{s}$ flood event $4 / 17 / 2011-4 / 18 / 2011$, b) $245 \mathrm{~m}^{3} / \mathrm{s}$ flood event $4 / 30 / 2011-5 / 1 / 2011$, and c) $355 \mathrm{~m}^{3} / \mathrm{s}$ flood event 5/18/2011 - 5/20/2011 that removed large amounts of sediment and the majority of plantings from the area. 

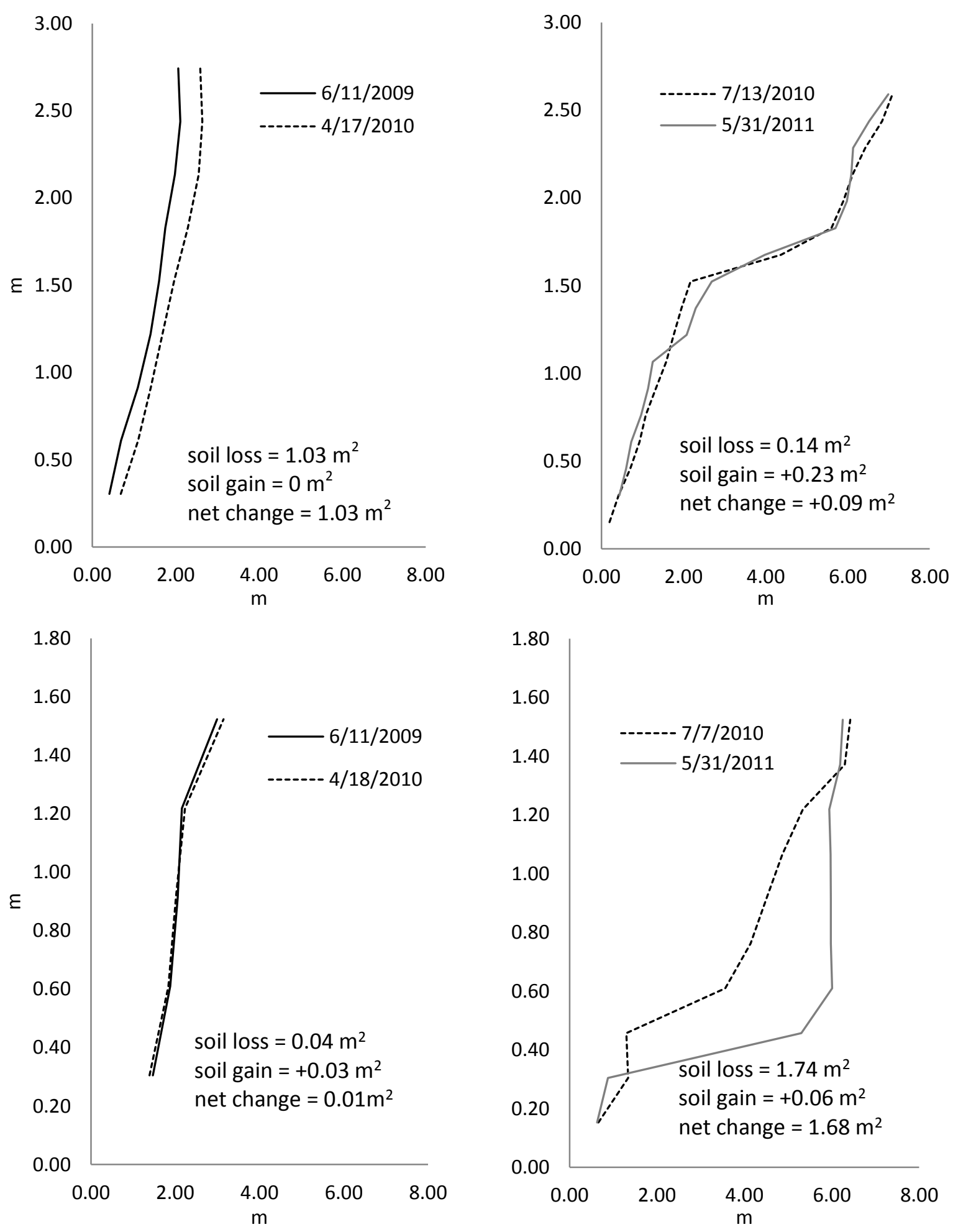

Fig. 7 Representative streambank profiles of a) a site within sub-reach Rest-1 in 2009 (one year before restoration) and b) 2010 (immediately preceding restoration). A “+” sign indicates net aggradation. Also shown are profiles from c) a location within sub-reach Rest-3 in 2009 (one year prior to restoration) and d) 2010 (immediately preceding restoration). 


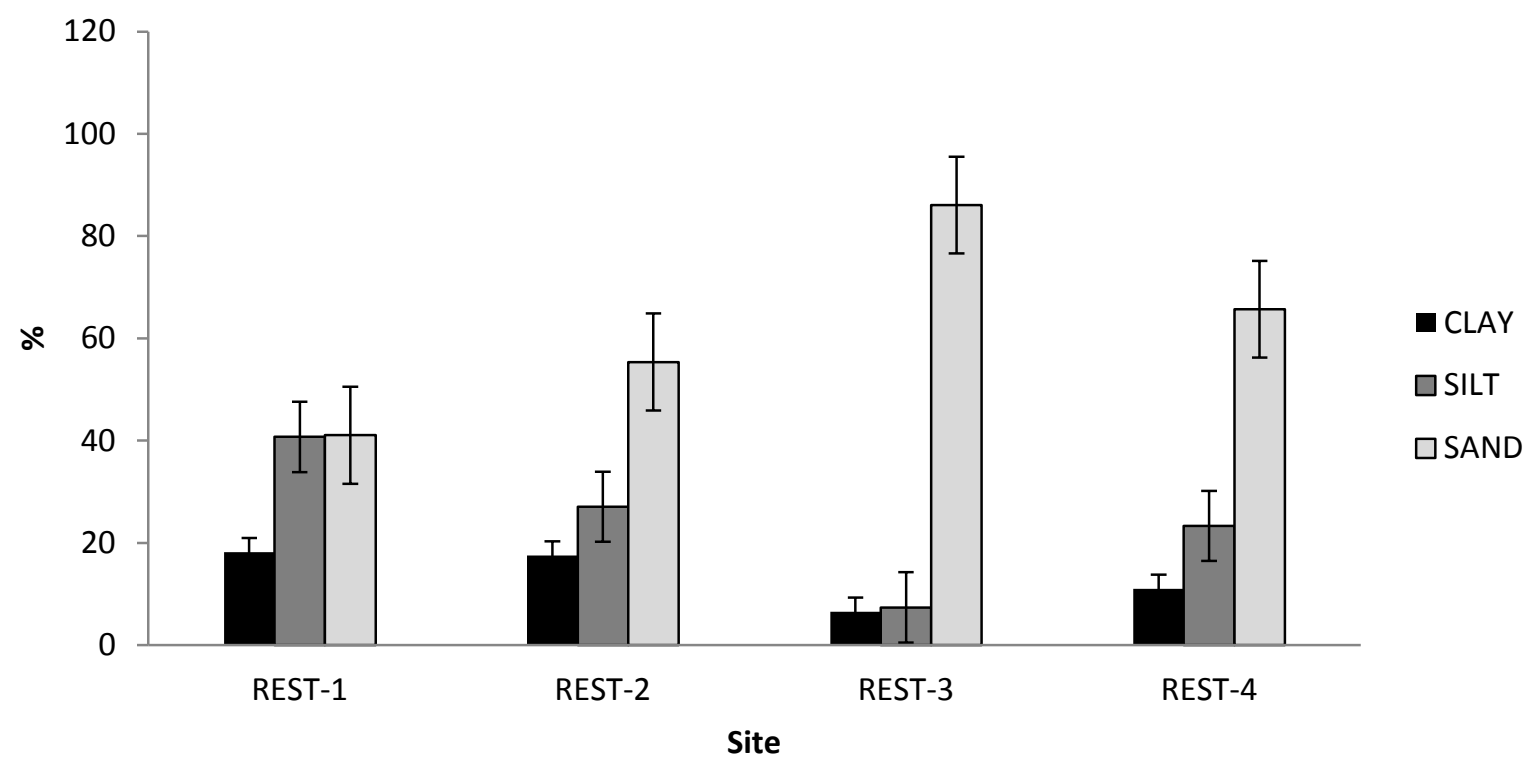

Fig. 8 Average percentages of clay, silt, and, sand in 2009 at four sub-reaches along a restored reach on the Cacapon River, West Virginia. 
a)
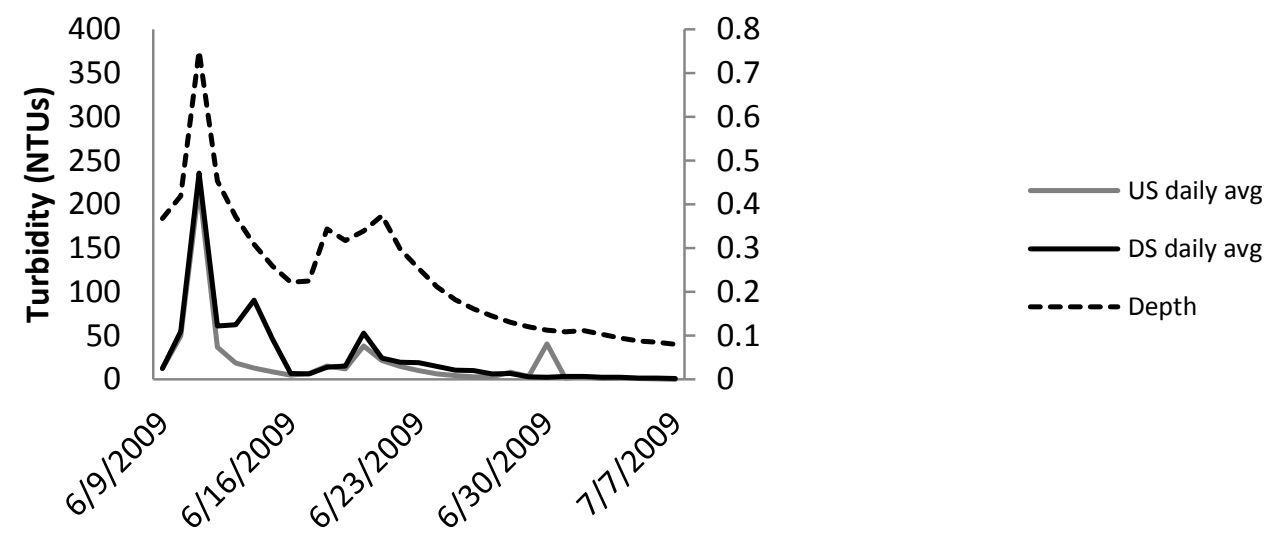

b)

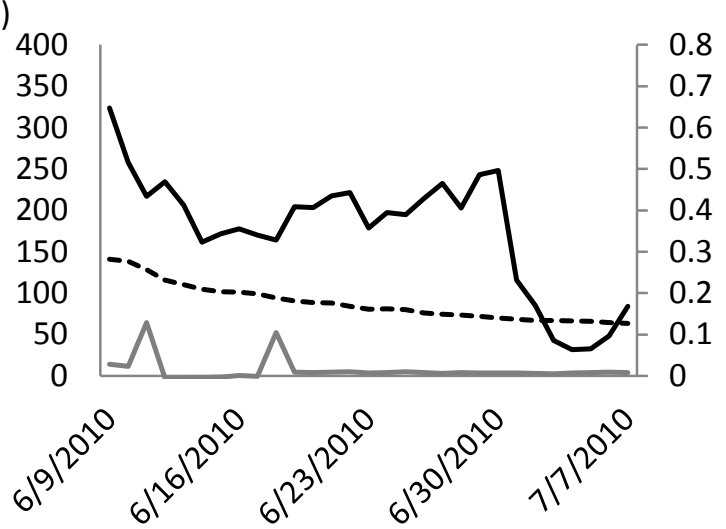

c)

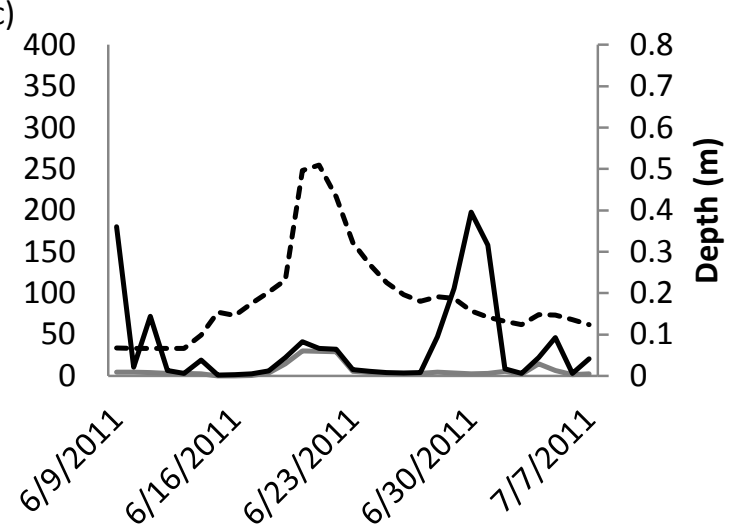

Fig. 9 Daily average turbidity upstream and downstream of an $750 \mathrm{~m}$ reach of the Cacapon River, West Virginia during a) June 2009 (one year before restoration), b) June 2010 (during the active construction phase), and c) June 2011 (one year after restoration). 


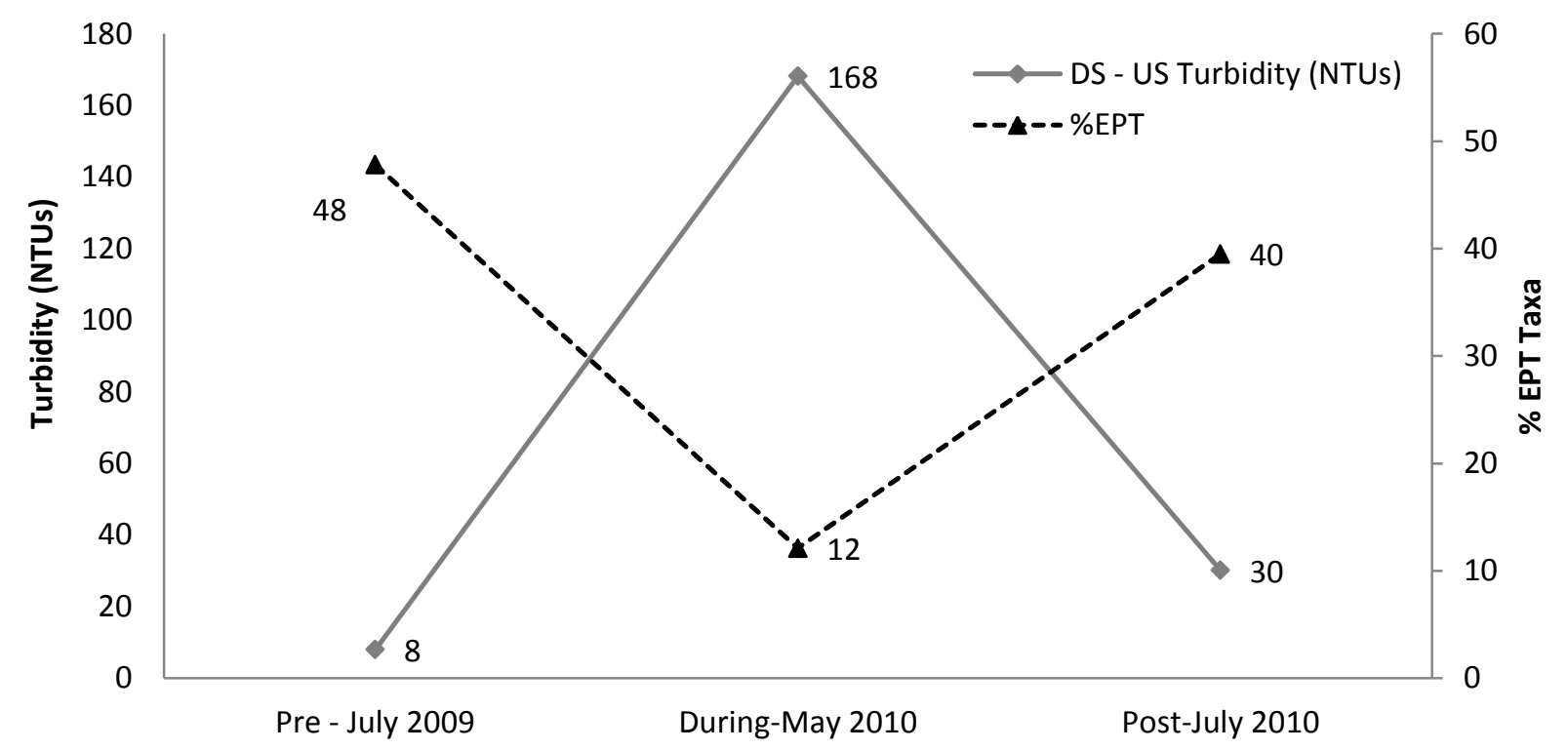

Fig. 10 The average difference in upstream and downstream turbidity levels and corresponding \% Ephemeropteran, Plecopteran, and Trichopteran (EPT) taxa of macroinvertebrate samples collected from the restored reach before restoration, during construction, and approximately two weeks after construction ended.
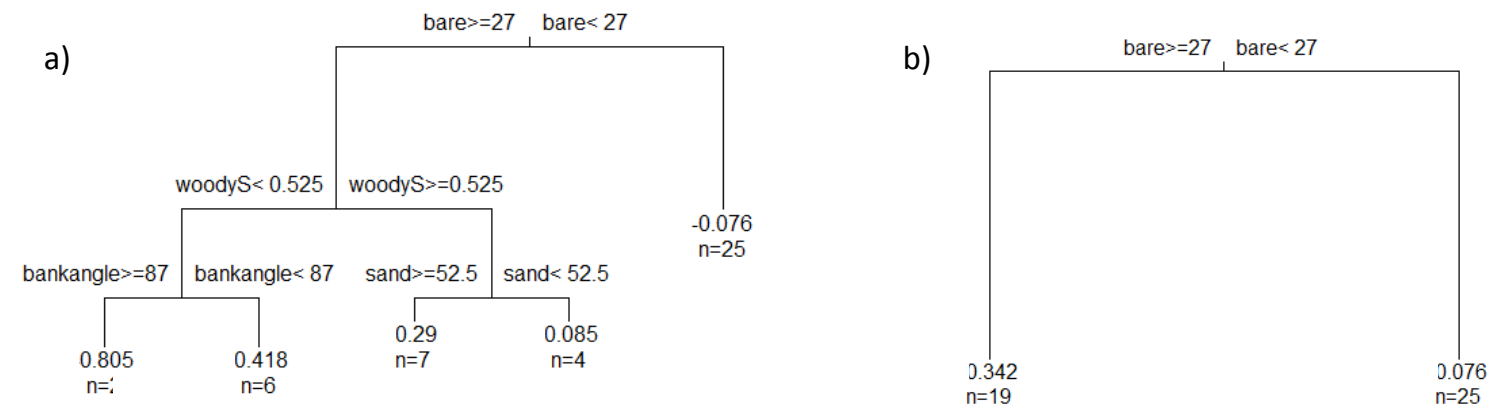

Fig. 11 Regression tree a) with the lowest cross-validation error (0.81) and b) within one SE of the crossvalidation error (0.92) used to explain variation in streambank migration rates $(\mathrm{m} / \mathrm{yr})$ at 44 sites in the Cacapon River Watershed, West Virginia from 2009 - 2010. For a), the first division is the percentage of bare ground (bare) followed by Shannon-Weiner diversity of woody vegetation (woodyS), bank angle (bankangle), and percentage of sand (sand). For b), the percentage of bare ground (bare) was the only variable used for the tree as it explained the majority of variation in migration rates (39\%). Average migration rates and sample sizes are shown below each corresponding terminal branch and the depth of each leaf is related to the percent of variation explained by the dependent variable at each node. 


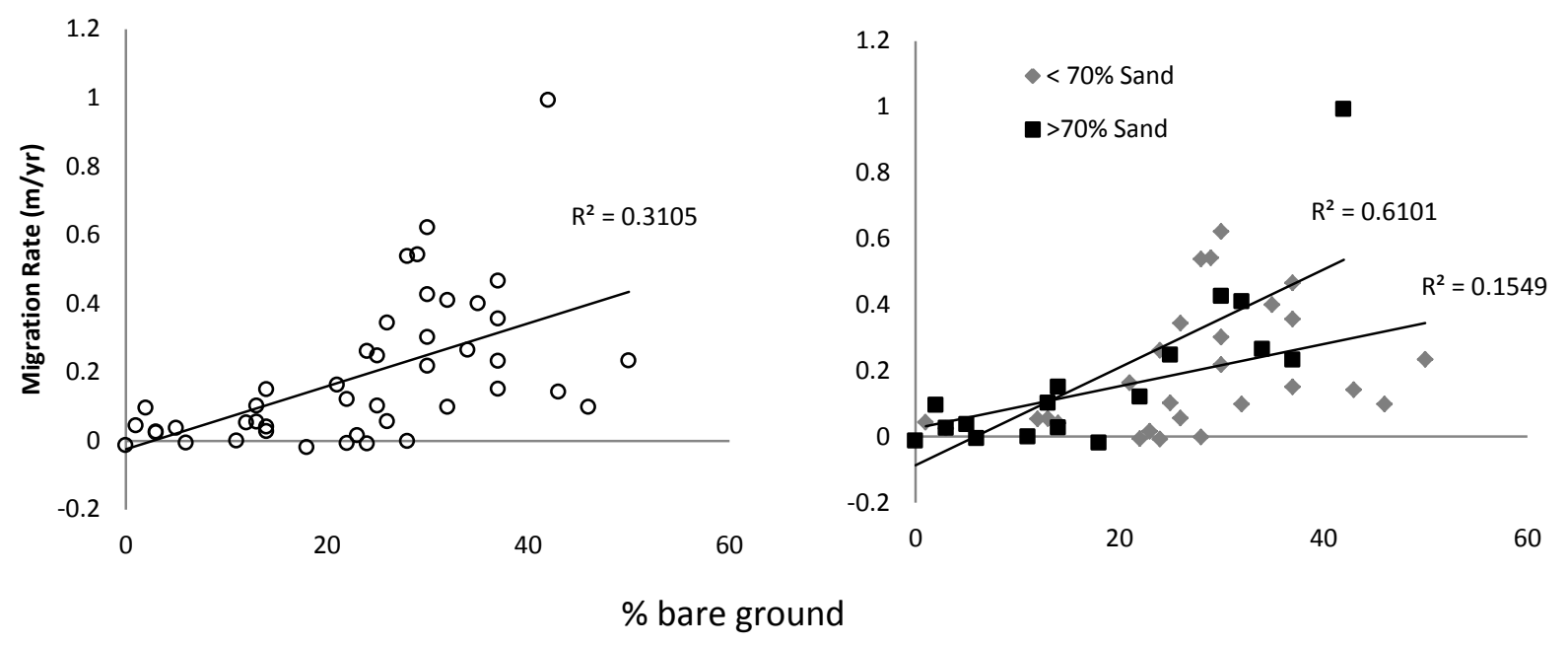

Fig. 12 Correlations between the average percentage of bare ground and streambank migration rate for a) all sites without stratification, and b) all sites stratified by the percentage of sand greater or less than $70 \%$ using data collected from 2009-2010 in the Cacapon River Watershed, West Virginia. 


\title{
CHAPTER III
}

\section{MODELING STREAMBANK EROSION POTENTIAL USING PROBABILITY MODELING IN A CENTRAL APPALACHIAN WATERSHED}

\author{
Jonathan L. Pitchford ${ }^{1}$, Michael P. Strager ${ }^{1}$, LianShin Lin $^{2}$, Adam Riley ${ }^{3}$, and \\ James T. Anderson ${ }^{1}$ \\ ${ }^{1}$ West Virginia University, Division of Forestry and Natural Resources, PO Box 6125, \\ Morgantown, WV 26506-6125 \\ *Corresponding Author e-mail: jpitchfo@mix.wvu.edu \\ ${ }^{2}$ West Virginia University, Department of Civil and Environmental Engineering, \\ PO Box 6103, Morgantown, WV 26506-6125 \\ ${ }^{3}$ Natural Resource Analysis Center, West Virginia University \\ 2009 Agricultural Sciences Building, Evansdale Dr. PO Box 6108, Morgantown, WV 26506-6108
}

Written in the style of:

Water Resources Research 


\begin{abstract}
Since the inception of the Clean Water Act, increases in funding for water resource management has created a niche for assessment tools that enhance watershed planning and conservation. The purpose of this study was to address this demand by creating a maximum entropy model of streambank erosion potential (SEP) in a Geographic Information System (GIS) framework that could be used primarily to prioritize sites for management and to determine which variables in the watershed are associated with excessive rates of streambank erosion. Model development included measuring erosion rates throughout a central Appalachian watershed, application of a quantitative approach to locate target areas for management termed Target Eroding Areas (TEAs), and collection of environmental data throughout the study extent using high resolution, remotely sensed data. We successfully constructed a likelihood distribution of TEAs from occurrence records and associated environmental variables over our study extent using the program Maxent. All model evaluation procedures indicated that the model was an excellent predictor of TEAs, and that the major environmental variables controlling these processes were streambank slope, soil characteristics, shear stress, and underlying geology. A classification scheme with low, moderate, and high levels of erosion potential derived from logistic model output was able to differentiate sites with low erosion potential from sites with moderate and high erosion potential. A major application of this type of modeling framework is to address uncertainty in stream restoration planning, ultimately helping to bridge the gap between restoration science and practice.
\end{abstract}

\title{
1. Introduction
}

In 1972, the Clean Water Act (CWA) became the most important legislation protecting water resources in the U.S. as it established a framework for regulation and awareness of water quality impairment, and has resulted in drastic improvements in water quality management over the last several decades [Bohn and Kershner, 2002; Houck, 2002]. More recently, the role of river management in restoring water quality has increased as great effort has been expended to actively restore ecosystem 
functions within degraded watersheds that have been heavily impacted by human activities such as urbanization, mining, and agriculture [Bohn and Kershner, 2002; Roni et al., 2002; Agouridis et al., 2005; Wohl et al., 2005]. As efforts to actively restore these functions have grown, so has the need for assessment tools that enable resource managers to make informed decisions about where to focus management efforts [Russel et al., 1997; Rosgen, 2001; Vitalis and Manoliadis, 2002; Evans et al., 2003; Goetz, 2006; Strager and Rosenberger, 2006; Strager et al., 2011]. The use of geographic information systems (GIS) has become an important part of watershed management by facilitating assessment of large areas using remotely sensed data [Russel et al., 1997; Evans et al., 2003; Yuksel et al., 2008; Strager et al., 2011]. Continued improvement in the quality and availability of remotely sensed data and additional improvements in analysis capabilities have further increased the value of GIS for river management [Goetz, 2006].

A major component of river management is stream restoration which includes a variety of approaches attempting to create conditions for water quality improvement and improved ecosystem functioning [Kondolf and Micheli, 1995; Rosgen, 1996; Bohn and Kershner, 2002; Roni et al., 2002; Palmer and Bernhardt, 2006; Wohl et al., 2005]. Recently, stream mitigation banking programs are being initiating in many areas that involve restoration or enhancement of streams to compensate for impacts on similar aquatic systems that often occurs in advance of impacts [Strager et al., 2011]. A common goal of these projects is to achieve greater stability of streambanks [Rosgen, 1997; Doll et al., 2003; Hasset et al., 2005; Wohl et al., 2005; Lave et al., 2010] to protect landholdings and infrastructure while improving water quality by reducing sediment and nutrient inputs originating from streambanks [Rosgen, 1997; Doll et al., 2003]. The effectiveness of restoration at achieving stream channel stability is heavily influenced by site selection, where sites with the greatest restoration potential will have the best chances of success following project completion [Wohl et al., 2005]. As such, the role of assessment tools that facilitate the site selection process is expanding as the demand for restoration continues to grow [Strager et al., 2011].

A large number of models and assessment tools have been developed to predict streambank erosion that vary greatly in parameter selection and precision, which has implications for the scale and 
applications for which they are relevant [Merritt et al., 2003]. Bank Stability Toe Erosion Model (BSTEM) is a highly complex physics based model used in engineering applications that predicts critical conditions associated with streambank failure using a large set of parameters including pore water pressure, hydraulic conductivity, and geotechnical data (e.g., friction angle, critical shear stress, etc.) to calculate a site specific factor of safety $\left(\mathrm{F}_{\mathrm{s}}\right)$ for a given streambank, which relates to the likelihood of bank failure [Simon et al., 2003]. An example of a widely used, empirical model of erosion potential is Bank Erosion Hazard Index (BEHI), which is a critical component of Natural Channel Design (NCD), and is used to predict erosion potential at the reach scale using average measures of stream channel geometry (e.g., bank height/bankfull height ratio, bank angle, root depth/bank height ratio) and riparian vegetation (e.g., surface protection, root density) to evaluate potential for streambank erosion in a selected reach [Rosgen, 2001]. Another empirical model, the Universal Soil Loss Equation (USLE), is among the most widely used models for watershed management in the world. It is used for predicting the quantity of sediment loads within a given watershed and contains a calculation to estimate sediment contributions from streambanks at the watershed-scale based on characteristics such as land use, topography, and soil erodibility [Evans et al., 2003; Ellis et al., 2011]. While each of these models has proven to be useful for prediction and resource management [Simon et al., 2003, Van Eps et al., 2004, Evans et al., 2003], a niche remains for models that provide a balance between high resolution prediction and large-scale applicability. A growing number of restoration scientists agree that where we are doing restoration and the scale at which the project is implemented is a critical component of effective restoration [Kondolf and Micheli, 1995; Roni et al., 2002; Palmer et al., 2003; Wohl et al., 2005]. Widely used models in stream restoration such as BEHI are useful for initial assessment of a stream reach [Van Eps et al., 2004], but may be too subjective and imprecise to reliably predict erosion potential [Harmel et al., 1999], and thus inform restoration site selection and prioritization. More objective decision support tools that incorporate GIS and quantitative analyses such as probability modeling could remove some of the subjectivity out of the site selection process and facilitate development of comprehensive watershed-scale restoration plans 
[Wohl et al., 2005] by providing information about relative streambank stability within the context of the watershed.

Probability models of streambank erosion potential (SEP) have been developed in GIS frameworks where erosion potential is modeled as a function of lateral and upstream distance of a grid cell to the active river channel and the frequency and magnitude of flood events in a given year based on principles of spatial autocorrelation [Winterbottom and Gilvear, 2000; Graf, 1984]. These models apply quantitative, raster-based analyses to determine probability of erosion for each grid cell within a predefined study area and were originally designed to predict channel response to changes in flood magnitudes. While initial modeling efforts accurately predict channel change over time, inclusion of streambank morphology, soil composition, and floodplain vegetation variables enhanced predictive power of these models [Winterbottom and Gilvear, 2000]. Recent improvements and availability of remote sensing data [Goetz, 2006] used in conjunction with complex Bayesian analyses has the potential to improve the resolution and precision of SEP prediction over larger extents [Boleneus et al., 2001; Phillips et al., 2006; Moghaddam et al., 2007; Dahal et al., 2008; Regmi et al., 2010].

Bayesian reasoning is an inductive method used in disease diagnosis [Aspinall, 1992], mineral exploration [Agterberg et al., 1993], landslide susceptibility modeling [Dahal et al., 2008; Moghaddam et al., 2007; Regmi et al., 2010], and wildlife habitat modeling [Aspinall, 1992; Phillips et al., 2006]. Bayesian approaches use map integration and map correlation to predict the occurrence of a resource of interest where a sufficient number of co-occurrences of map features (i.e., geologic, geochemical conditions) indicate a greater probability of occurrence of the resource [Boleneus et al., 2001; Agterberg et al., 1993]. The utility of these methods for predicting landslide susceptibility has been explored in several areas using records of landslide occurrence and environmental layers that represent features that influence occurrence such as topography, hydrology, land cover, etc., and have been used to protect infrastructure and prevent human casualties [Dahal et al., 2008; Moghaddam et al., 2007; Regmi et al., 2010]. Predicting areas where excessive streambank erosion is likely to occur would rely on many of the same landscape variables used to predict landslide occurrence (e.g., slope, flow accumulation, soil type) 
and could similarly play a large role in management decisions such as helping to identify areas that need management, and providing insight on the most important variables driving streambank erosion problems in a given watershed.

A specific Bayesian modeling approach called maximum entropy is a general purpose, machine learning method that enables prediction from incomplete information [Phillips et al., 2006], and has been used to estimate a target probability distribution of feature occurrence (e.g., wildlife species, mineral resource, etc.) as a function of environmental variables (e.g., geology, elevation, etc.). Maximum entropy does this by finding the most uniform distribution of the feature under a set of constraints that represent incomplete knowledge of the actual distribution of the feature [Manning and Schutze, 1999; Phillips et al., 2006]. There are several advantages of maximum entropy over other Bayesian modeling approaches including: 1) the need for presence only data for the feature of interest, 2) the ability to use continuous and categorical predictor data, 3) the use of deterministic algorithms that converge to a distribution of maximum entropy, 4) maintenance of a stable distribution with limited training data, 5) easily interpretable, continuous output scores, and 6) allowance for assessment of relative importance of predictor variables [Phillips et al., 2006; Dudik et al., 2007; Pearson, 2007]. Maximum entropy is also less stringent than traditional regression-based models as variables are allowed to possess multicolinearity and be spatially autocorrelated [Beane, 2010; Hu and Jiang, 2010]; however, maximum entropy is similar to logistic regression in that each predictor variable is weighted by a constant and the estimated distribution is divided by a scaling constant that allows all probabilities to sum to one over the extent of interest [Hernandez et al., 2006]. These advantages make this method especially useful for modeling with incomplete information as the maximum entropy distribution is built only from what is known about the occurrence of feature and its associated variables while avoiding making assumptions about anything unknown [Jaynes, 1989].

We are interested in the utility of a Bayesian probability modeling approach, maximum entropy, for modeling SEP using occurrence localities or target eroding areas (TEAs) for streambank erosion along with environmental factors that likely influence or drive erosive processes. We accomplished this by 1) 
measuring streambank erosion rates throughout a portion of a central Appalachian watershed, 2) applying a quantitative approach to locate TEAs, 3) developing a set of remotely sensed predictor layers that are commonly associated with streambank erosion, and 4) using the principles of maximum entropy to generate a likelihood distribution for SEP within the study area. A potential application for the model is to facilitate improved site selection and prioritization leading to improved stream restoration strategies and greater success of restoration projects.

\section{Methods}

\subsection{Study Area}

The Cacapon River Watershed is a sub-watershed of the Potomac River basin within the Appalachian Mountains in the Ridge and Valley physiographic province of West Virginia and includes the North, Lost, and Cacapon rivers (Figure 1). The watershed drains about 2,320 $\mathrm{km}^{2}$ within Hardy, Hampshire, and Morgan counties [Constantz et al., 1995]. The majority of land in the watershed is forested (i.e., 79\%), with some agriculture (i.e., 19\%), and residential development (i.e., 2\%), and climate is humid continental, characterized by hot summers, cold winters, and average annual precipitation near $90 \mathrm{~cm}$ (available from the Cacapon Institute at http://www.cacaponinstitute.org/index.htm). The most recent monitoring report indicated that the watershed has good water quality, and that potential water quality stressors are non-point sources of sediment and nitrogen that enter the river via runoff from agricultural and logging operations, which are heaviest in sections of the Lost and Cacapon rivers [Constantz et al., 1995].

An $8.8 \mathrm{~km}^{2}$ portion of the Cacapon River watershed representing only riparian areas along the stream network was selected for development of a model of SEP (Figure 1). This area includes $113 \mathrm{~km}$ of $1^{\text {st }}-3^{\text {rd }}$ order streams, and comprises a portion of the watershed with the most extensive agricultural impacts [Constantz et al., 1995]. Streams in the study area typically flow through wide, slightly entrenched, shallow channels [Pitchford, 2012] where median daily flow rates ranged from $2-31 \mathrm{~m}^{3} / \mathrm{s}$ in the mainstem and from $0.04-1.2 \mathrm{~m}^{3} / \mathrm{s}$ in a representative tributary during the study period (available 
from the USGS at www.waterdata.usgs.gov/usa/nwis/uv?site_no01611500 and www.waterdata.usgs.gov/usa/nwis/uv?site_no=01610400). Elevation within the study area ranges from $210-423 \mathrm{~m}$ and the underlying geological units consist of decreasing portions of alluvium (47\%), shale (29\%), sandstone (17\%), and limestone (6\%) [West Virginia Geological and Economic Survey, 2011]. Streams throughout this portion of the watershed are typically single thread, meandering, gravel bed streams with occasional segments that exhibit braiding and oxbow formations.

\subsection{Quantifying streambank erosion}

Field reconnaissance of the study area was conducted from canoe from 2009 - 2010 where sites were selected using Pfankuch stream reach inventory [Pfankuch, 1975] (Appendix IIIa) to identify reaches considered in "fair" or "poor" condition. A total of 151 locations distributed among 30 stream reaches, each ranging from 100 - $300 \mathrm{~m}$ in length, were selected to quantify streambank erosion rates using erosion pin and streambank profile surveys [Van Eps et al., 2004; Luppi et al., 2008; Hupp et al., 2009]. At each reach, 4- 10 equally spaced survey sites were established using survey pins and the location of each site was recorded with a Garmin Inc. (Kansas City, Mo) Etrex Legend HCx geographic positioning system (GPS). Streambank migration rates were measured by inserting three, $122 \mathrm{~cm}$ long, $0.95 \mathrm{~cm}$ diameter reinforcing rods arranged in a vertical profile into the bank face using a hammer until almost flush [Luppi et al., 2008; Hupp et al., 2009]. Location of erosion pins and pin length exposed were recorded during each survey. The change in pin length between subsequent surveys was averaged for each survey site and used to calculate migration rate. Migration rates were calculated in $\mathrm{m} / \mathrm{yr}$ for each survey site by standardizing the average pin reading using the following equation.

$$
\text { (average } \Delta \text { in pin length } \div \text { days between surveys) } \times 365
$$

Streambank profile surveys were used to calculate net change in sediment storage at each site by establishing a benchmark in the lower bank area [Rosgen, 2001; Van Eps et al., 2004]. Surveys were conducted using a level survey rod anchored to a tripod placed directly adjacent to the upstream side of the benchmark. The horizontal distance from the survey rod to the streambank was recorded every 15.24 
$\mathrm{cm}$ from the benchmark to the top of the bank using a Bosch ${ }^{\mathrm{TM}}$ DLR130 laser distance measurer. After completing each streambank profile survey, photos were taken of the bank face, in the upstream direction, and in the downstream direction to help assess changes occurring within monitored reaches over time. After completing surveys at each site, one surveyed location was chosen at random and re-surveyed to assess measurement error for the site. Profile survey coordinates were imported into ESRI® ArcMap ${ }^{\mathrm{TM}}$ 10.0 and a line was digitized between points to represent streambank profiles for each year. Next, profiles for each survey year were overlaid and polygons were digitized to represent soil loss and soil gain between subsequent surveys. The area of each digitized polygon was calculated using the "Calculate Geometry" function in ArcMap and a rate of change in sediment storage was calculated for each survey site by summing sediment loss and gain to obtain net change in storage, which was used in the following equation for standardization.

(net change in sediment storage $\div$ days between surveys) $\times 365$

\subsection{Target eroding areas}

To determine which survey locations represent TEAs, we used cluster and outlier analysis (Anselin Local Moran’s I) within the spatial statistics toolbox within the program ESRI ${ }^{\circledR} \operatorname{ArcMap}^{\mathrm{TM}}$ 10.0. This analysis calculates a local Moran's I statistic for each feature where a positive statistic for a feature indicates that neighboring features have similar values while a negative statistic indicates that a feature's neighbors have dissimilar values and is therefore an outlier. The analysis produces a $Z$-score, $P$ value, and a code that represents cluster type for each feature which can be used to determine the presence of statistically significant hot or cold spots for features of interest. This analysis was conducted for migration rates calculated from erosion pin surveys and from rates of change in sediment storage calculated from repeated streambank profile surveys to determine locations of significant clustering of high erosion rates. Inverse distance was used for conceptualization of spatial relations as it is better suited for applications with continuous erosion rate data where sites in close proximity are likely to influence one another. Euclidian distance was chosen for the distance method for this analysis, and the default 
fixed distance band value was used to ensure that each feature had at least one neighbor. Sites that had statistically significant clustering (i.e., $Z>1.65 ; \alpha<0.1$ ) of high erosion rates using either survey method were considered to be TEAs. At sites where all erosion pins were lost during the year, a conservative average migration rate of $0.61 \mathrm{~m}$ was assigned for that site, which is half the length of an erosion pin. This was considered appropriate given that erosion pins are more easily dislodged from the streambank by water or floating debris during high flow events when a larger portion of the pin is exposed than remains anchored in the streambank. If a toe pin was lost from a site between survey years, the site was not used in analyses for rate of change in sediment storage because no benchmark was available for surveys, and because toe pin loss was the result of channel incision, which was not of interest in this study.

\subsection{Predictor variables for SEP}

Airborne Light Detection and Ranging (LiDAR) was flown over the study area on April 22, 2010 by the West Virginia University Natural Resource Analysis Center (WVUNRAC) at approximately 1,676 $\mathrm{m}$ above ground level at an average speed of 135 knots using the following parameters: pulse rate frequency of $70 \mathrm{kHz}$, scan frequency of $30 \mathrm{~Hz}$, and scan angle of $18^{\circ}$ (36 full field of view). The scanner used for data collection was an Optech Inc. (Ontario, Canada) ALTM3100, which fired up to 100,000 laser pulses per second with an accuracy within $15 \mathrm{~cm}$ of the vertical axis, with at least one shot per $\mathrm{m}^{2}$ with four vertical returns. Sensors for LiDAR collection included GPS, Inertial Measurement Unit (IMU) compensation, and laser ranging mounted in a Piper Navajo twin engine aircraft which enabled production of highly accurate and precise terrain mapping of the study area. WVU NRAC post-processed the data and a ground model was derived from the LiDAR data to create Log ASCII Standard (LAS) files of the study area, which were used to create digital elevation models (DEMs) in ESRI® ArcGIS ${ }^{\mathrm{TM}} 10.0$ by converting LAS files to multipoint files using the 'LAS to multipoint' tool in the 3D Analyst Conversion toolbox. Raster data sets were created from multipoint files using the Inverse Distance Weighted ('IDW') interpolation tool in the Spatial Analyst toolbox, specifying a power of two and an 
output cell size of one m. These steps were followed to create bare earth DEMs using last return LAS files and reflective surface DEMs that represent vegetation using first, second, and third return LAS files for the study area.

Fourteen environmental layers were created using various geoprocessing functions within the program ESRI® $\operatorname{ArcMap}^{\mathrm{TM}} 10.0$ to represent features commonly associated with streambank erosion (Table 1). The majority of layers were created from DEMs derived from LiDAR data. Soil type and soil erodibility were created from 1:20,000 SSURGO soil maps [USDA, 2011] and underlying geology was created from 1:100,000 scale West Virginia Geological and Economic Survey (WVGES) geologic maps [West Virginia Geological and Economic Survey, 2011]. Bank stress index was adapted from a rating system used to estimate near bank stress based on the ratio of radius of curvature of the stream channel and channel width [Rosgen, 2001]. For the purposes of this study, we used a total of four categorical levels (i.e., non-bank, low, medium, and high) to represent shear stress ratings where areas within the channel boundary were classified as non-bank, low was assigned to areas on the inside of meander bends (i.e., depositional areas) medium was assigned to areas along straight reaches, and high was assigned to areas on the outside of meander bends (i.e., degradational areas).

A polygon was digitized to represent all stream channels (i.e., left and right channel boundary) using a hillshade layer derived from a one $\mathrm{m}$ bare earth DEM. The study extent was defined by placing a $30 \mathrm{~m}$ buffer on the channel polygon, which was used as a template for extraction of all environmental layers. Environmental layers that contained $1 \times 1 \mathrm{~m}$ cells were converted to $3 \times 3 \mathrm{~m}$ grids using the 'Resample' tool in the spatial analyst toolbox, specifying bilinear interpolation as the re-sampling method. All layers were then extracted to the study extent and converted to ASCII format, and coordinates of TEAs were converted to CSV format for model building.

\subsection{Model building}

The computer program, Maxent, version 3.3.2 (available for download at http://www.cs.princeton.edu/ schapire/maxent/), was used to model SEP by estimating the unknown 
distribution $(\pi)$ over the set of pixels in the study area $(\mathrm{X})$. Maxent assigns a probability of occurrence to each point, $\mathrm{x}$, that is approximated by solving for the entropy of $\hat{\pi}$ using the equation:

$$
H(\hat{\pi})=-\sum_{x \in X} \hat{\pi}(x) \ln \hat{\pi}(x)
$$

where $\ln$ is the natural logarithm, and $\hat{\pi}$ is a positive value representing the probability of occurrence for the target phenomena that sums to one over all the pixels in the study extent. Simply stated, this equation was used in this study to generate a distribution representing the log-likelihood of occurrence over the pixels within our study area that maximized entropy (i.e., was the closest to uniform) based on constraints representing our incomplete information regarding features associated with TEAs.

Because Maxent is a presence only modeling method where absence data are not needed, no assumptions are made regarding where a feature does not occur. However, the Maxent distribution does rely on pseudo-absence data points that are randomly chosen from all background data points. This means that the Maxent distribution primarily functions to distinguish between occurrence and random instead of occurrence and absence. The Maxent default total of 10,000 random points was used to build the distribution in our modeling effort. Categorical variables soil type, bank stress, and geology were specified as such while other layers were specified as continuous variables. A regularization value of two was selected to avoid model overfitting as the regularization multiplier affects the distribution of model output where a low value $(<1)$ would result in a more specific predicted distribution with smaller confidence intervals and lower entropy, and a higher multiplier $(>1)$ results in greater spread in the predicted distribution, larger confidence intervals, and higher entropy. Response curves and jackknife options were run within the program to measure variable importance. Additionally, 30 replicate bootstrap runs were selected under the options in the 'Settings' window using $25 \%(n=7)$ of the original $(n=29)$ training sites that represent TEAs. The 'Random seed' option was also selected for the bootstrap runs to ensure unique test and train datasets were used for each replicate model run. Because the total number of training sites was low, the bootstrap replication technique, which involves sampling from the original occurrence locations with replacement, helped to avoid losing valuable training data for model 
development. Bootstrapping worked in this sense to split the data into test and training data 30 times providing multiple estimates of model performance while allowing all occurrence data to be used with a random partition for each replicate run.

\subsection{Model validation}

Evaluation of model performance included a threshold-dependent, one-tailed binomial test on model omission and predicted area to determine if the maximum entropy distribution was predicting better than random. Also used to evaluate model performance was a threshold independent, area under curve (AUC) analysis, which was used to determine if a random positive instance and a random negative instance were correctly identified by the model. The AUC value ranged from $0-1$ and was used to assess overall model performance where a value of $<0.5$ indicates a model predicts no better than random, $0.5-0.7$ indicates fair model performance, $0.7-0.9$ indicates a good model, and values $>0.9$ are indicative of an excellent model [Phillips et al., 2006; Beane, 2010].

To evaluate environmental variable contributions to the model, logistic response curves were generated in the model output showing how each environmental variable affects the Maxent prediction using each variable by itself and in conjunction with all other variables when held at their mean value. Also generated were the percent contribution and permutation importance of each variable, and jackknife analyses to assess the importance of each variable by creating a model excluding the variable of interest and a model using only the variable of interest. Jackknife analyses ultimately helped to determine how much unique information was present in each variable as it relates to the test gain, training gain, and AUC values for each model of SEP.

To create a map of the model output, the ASCII logistic output for SEP that represented the average of all 30 model runs produced by Maxent was converted to raster using the 'convert to raster' tool in the Conversion Tools toolbox in ESRI® $\operatorname{ArcMap}^{\mathrm{TM}}$ 10.0. The raster layer was reclassified using the 'Reclassify' tool in the Spatial Analyst toolbox to produce a map by partitioning the data into three classes: low, moderate, and high SEP. Areas with low SEP were below the minimum training presence 
(MTP), or the minimum logistic threshold for which a presence record was found among the training sites. The other two partitions represent equal intervals of the remaining logistic output above the MTP. To test the strength of our classification scheme, we conducted a one-way Analysis of Variance (ANOVA) using classification (i.e., low, moderate, or high SEP) as the independent variable and normally distributed migration rates $(\mathrm{m} / \mathrm{yr})$ as the dependent variable for the original 151 sites where streambank erosion rates were quantified from 2010 - 2011 to test the hypothesis that our SEP classification was a reliable predictor of migration rate. A significant ANOVA was followed with a Tukey's Honest Significant Difference (HSD) post hoc test to compare migration rates between low, moderate, and high SEP. Significance for all tests was set at the $\alpha=0.05$ level.

\section{Results}

Migration rates for all sites ranged from $-0.11-0.95 \mathrm{~m} / \mathrm{yr}, 95 \%$ of which were eroding (i.e., had a positive migration rate) with an average migration rate of $0.24 \mathrm{~m} / \mathrm{yr}(\mathrm{SE}=0.02)$. Net change in sediment storage ranged from a net loss of $3.04 \mathrm{~m}^{2} / \mathrm{yr}$ to a net gain of $0.80 \mathrm{~m}^{2} / \mathrm{yr}$ for all sites, $84 \%$ were eroding with an average net loss of $0.39 \mathrm{~m}^{2} / \mathrm{yr}(\mathrm{SE}=0.06)$. All erosion pins were lost at $13 \%$ of monitored sites, while toe pins used as benchmarks for repeated streambank profile surveys were lost from $40 \%$ of sites indicating that erosion pins may be a more reliable method for quantifying erosion rates. A total of 29 TEAs were identified from the 151 monitored locations, 25 TEAs were detected based on migration rates ranging from $0.53-0.93 \mathrm{~m} / \mathrm{yr}$, and six TEAs were detected based on net sediment losses ranging from $1.2-2.29 \mathrm{~m}^{2} / \mathrm{yr}$. Only two sites were detected as TEAs using data from both survey methods.

Percent contribution and permutation importance values of initial model runs indicated that nine of the original 14 environmental variables were contributing unique information to the model and were considered important for attaining the highest level of model performance. The average training AUC value for 30 model runs using these nine predictor variables was $0.994(\mathrm{SE}=0.0004)$ indicating that the model was an excellent predictor of TEAs (Figure 2). Average test AUC for all model runs was 0.985 
$(\mathrm{SE}=0.002)$, further indicating a high level of model performance. Threshold dependent model evaluation conducted using the binomial omission test was significant $(P<0.01$, one tailed) for all data partitions at all selected threshold values indicating that the model predicted much better than random (Table 3). The average logistic threshold for the minimum training presence (MTP) for all model runs was 0.209 ( $\mathrm{SE}=0.02)$, which represents the lowest threshold value for a TEA used as a training point. All logistic threshold values greater than the MTP were considered to have moderate or high potential of being a TEA, which included only $3.1 \%\left(0.27 \mathrm{~km}^{2}\right)$ of the study extent.

The most important environmental variables in the model were slope (32.7\%), soil type (29.2\%), bank stress index (20.6\%), and underlying geology (8.7\%) (Table 3). Response curves show that the logistic probability of a TEA increased with increasing slope up to approximately $25^{\circ}$ and then declined as slope increased until an asymptote was reached just above a logistic probability of $50 \%$ (Figure 3a). The soil type with the highest SEP was Potomac with Fluvaquents and Philo-2 soils having the second highest probability, followed by Lithic Udorthents, and Philo-1 soils (Figure 3b). All other soil types in the study area had the same probability of being a TEA. Response curves also indicate that areas along the outside of meander bends had the highest probability of being a TEA followed by areas on the inside of meander bends, and other levels of bank stress having similar probability (Figure 3c). Areas with alluvium as underlying geological units had the highest logistic probability of being a TEA with areas containing sandstone, limestone, and shale exhibiting respective decreases in probability (Figure 3d). Jackknife analyses revealed that the variable that contained the most useful information when used in isolation was slope as indicated by the highest value of training gain among variables with soil type and bank stress index having the second and third highest gain when used in isolation, respectively (Figure 4a). Similar variable importance is indicated by the effect of variable removal on training gain as soil type, slope, and bank stress appear to provide more unique information to the model not present in the other variables. The variable that had the highest test gain when used in isolation was slope followed by soil type and bank stress index with similar variable importance indicated by the effect of variable 
removal on test gain (Figure $4 b$ ). Slope, soil type, and moisture index were the respective top three variables influencing AUC values when used in isolation (Figure 4c).

Our classification scheme built from logistic model output shows that $96.9 \%\left(8.5 \mathrm{~km}^{2}\right)$ of the study extent was below the MTP, and therefore considered to have low likelihood of being a TEA (Figure 5). Areas with moderate and high SEP made up $2.7 \%\left(0.24 \mathrm{~km}^{2}\right)$ and $0.3 \%\left(0.03 \mathrm{~km}^{2}\right)$ of the study extent, respectively. Statistical tests revealed that our classification scheme was a reliable predictor of streambank migration rate $\left(F_{1,149}=33.2 ; P<0.001\right)$ (Figure 6), as sites with low SEP, which had an average migration rate of $0.22 \mathrm{~m} / \mathrm{yr}(\mathrm{SE}=0.02)$ were different from sites with moderate $\mathrm{SEP}$ that had an average migration rate of $0.41(\mathrm{SE}=0.03)(P<0.001)$, and from sites with high $\mathrm{SEP}$ that had an average migration rate of $0.45(\mathrm{SE}=0.04)(P<0.001)$. Although average migration rates were slightly higher for sites with high compared to moderate SEP, we did not detect a difference between migration rates at sites in these categories.

\section{Discussion}

All model validation procedures indicated that our SEP model developed using the principle of maximum entropy can readily distinguish TEAs from random pixels within the study extent, and further testing of our classification scheme based on logistic model output indicated that the model could be very useful for differentiating sites with low SEP from sites with moderate or high SEP. These findings indicate that this type of modeling framework could be a valuable tool for prioritizing sites for management within the context of the watershed as it provides high resolution prediction over a large spatial extent. Also, such modeling frameworks could help to bridge the gap between stream restoration scientists and practitioners with regard to the form versus process debate as this type of approach should help to fill a niche for process models that will ultimately facilitate better informed watershed management [Bohn and Kershner, 2002; Wohl et al., 2005].

The most important variables used to model the presence of a TEA in this study were similar to other models of SEP where streambank slope, soil characteristics, shear stress, and underlying geology 
were the major environmental factors of importance for predicting SEP [Evans et al. 2003; Simon et al., 2003; Van Eps et al., 2004; Luppi et al., 2008]. Streambank slope was the most important factor in the majority of analyses of variable importance, and the response curve indicated that increases in slope resulted in greater probability of occurrence up to a threshold near $25^{\circ}$ before a gradual drop in probability. This finding is initially counterintuitive as such steep slopes would typically be considered an even greater erosion hazard; however, there are many areas along the Cacapon with very steep $\left(>60^{\circ}\right)$ slopes composed of shale where relatively little erosion occurs compared to streambanks composed of alluvium. No effort was made in this study to quantify erosion rates from steep shale slopes, and it is highly unlikely that a TEA would have been detected on shale outcrops during the short duration of this study; thus, the sharp drop in probability on slopes greater than $25^{\circ}$ may be best explained by these areas being unrepresented as TEAs.

Soil type was a close second among variables as a predictor of TEAs as areas containing Flavaquents, Potomac, and Philo soils all had the highest probability of presence. Flavaquents and Philo soils contain as much as $85 \%$ sand in deeper horizons (i.e., $1-2 \mathrm{~m}$ ), and Potomac soils can contain as much as $100 \%$ sand in deeper horizons [USDA, 2011], which could predispose these areas to excessive erosion along stream corridors where deep soil horizons are often exposed due to channel incision. The percentage of sand in streambanks is a critical component of channel stability where areas with higher portions of sand are more susceptible to fluvial erosion [Heede, 1980; Micheli and Kirchner, 2002; Simon et al., 2003; Simon et al., 2007; Simon et al., 2008, Pitchford, 2012], and thus could be responsible for higher SEP in areas with these soil types.

Bank stress index was the third most important environmental variable where sites on the outside of meander bends had much higher probability of presence compared to other levels of bank stress. This was an intuitive finding as the outside of meander bends are almost always degradational areas [Bloom, 1998]. Underlying geological units also had measureable effects on the probability of presence as sites comprised of alluvium were more likely to be TEAs. This is no surprise given that alluvium represents previously eroded material transported by water, and Flavaquents, Potomac, and Philo soils associated 
with TEAs are alluvial soils. Also, alluvial soils are clearly the most mobile of the four geology types in our study area, and the majority of sites considered in fair or poor condition as determined by Pfankuch Stream Reach Inventory [Pfankuch, 1975] were in alluvial soils.

Our classification scheme was effective for differentiating sites with low SEP from sites with moderate and high potential, but could not distinguish between moderate and high potential. Although variability in streambank migration at sites in these classes overlapped, a larger sample size among sites with moderate and high potential would likely improve the ability to detect a difference as these classes. This is particularly true for sites with high potential, which were underrepresented in statistical tests. Even so, our results clearly show that this type of modeling framework has utility for gauging relative stability at the watershed $\left(50-500 \mathrm{~km}^{2}\right)$, segment $\left(100-10000 \mathrm{~m}^{2}\right)$, or reach $\left(10-1000 \mathrm{~m}^{2}\right)$ scale and could be useful for preventing unnecessary construction in areas within a reach that are relatively stable, yet may appear to be degrading. Such areas can become a liability following vegetation removal and subsequent reductions in floodplain roughness along recently reconstructed streambanks that have been shown to cause bank failure during only moderate sized flow events [Smith and Prestegaard, 2005, Pitchford, 2012].

Although most streambank erosion models are used to estimate sediment contributions from streambanks [Merrit et al., 2003], the primary application of this model is to allow the user to gauge relative stability. We chose to use the logistic output to create only three classification levels; however, we could have created a map with a continuous prediction where each pixel has a unique SEP score relative to all other pixels within the extent, or generated a larger number of classes to represent SEP. This could be a useful approach if there are many degraded areas in a watershed where a more precise understanding of relative stability is needed for site prioritization. Another attractive quality of this type of model is that much can be learned about the relative restoration potential of sites where, for example, areas with high SEP containing soil types with higher clay content positioned along straight reaches have higher probability of restoration success compared to areas with sandy soils in degradational areas on the outside of meander bends. Other applications for the model include greater understanding of conditions 
associated with stable sites within the watershed, which could help to inform restoration design similar to the popular "reference reach" approach used in Natural Channel Design (NCD) [Rosgen, 1998].

A limitation in this study was the small sample size of TEAs used to train the model; however, these data were chosen from 151 sites where erosion rates were measured, and only those areas that represented statistically significant TEAs were chosen as occurrences. This was done so that only those sites with excessive streambank erosion rates, surrounded by sites experiencing similar magnitudes of change, were used to train the model. Also, we obtained 30 estimates of model performance using the bootstrapping option in Maxent, all of which indicated excellent model performance, further increasing our confidence in variable importance values and the predicted spatial distribution of SEP. A second limitation is the spatial distribution of TEAs, which exhibit spatial autocorrelation as indicated by very low training omission rates. This can result in a higher cumulative prediction in relation to the spatial area examined [Phillips et al., 2006; Beane, 2010]. This is not surprising given that all sites are located along a stream network and that two or more TEAs were detected along the same stream reach in several instances. However, maximum entropy models have proven robust to spatial autocorrelation among complex ecological and topographic data where correlated and uncorrelated models have performed similarly indicating that model regularization, which was used in our models, prevents overfitting compared to regression based models [Hu and Jiang, 2010].

A major assumption of our model involves the principle of stationarity, in which features remain unchanged during the period of study [Merritt et al., 2003]. This is likely an important consideration for modeling SEP as topographic features (i.e., slope, curvature, etc.) or changes in vegetation structure (i.e., vegetation height) due to timber harvesting or grazing may have resulted in changes in predictor variables following LiDAR surveys. This could result in some areas being more or less susceptible to erosion during the study period. However, changes in surface topography were likely minor and would have been restricted primarily to areas where mass wasting occurred, and changes in vegetation structure would only have occurred in a few areas. All other predictor variables (i.e., soil type, bank stress, and underlying geology) likely remained the same during the study period. Another assumption we made was that all 
influential environmental variables, as determined by variable importance values, should remain in the final model. This is based on the idea that Bayesian modeling approaches like maximum entropy exhibit enhanced predictive power by inclusion of as many predictor features as are available to the user, which provides more information to the classifier and can only enhance model performance [Phillips et al., 2006].

Since the inception of the Clean Water Act in 1972, increases in funding for water resource management has created a niche for assessment tools that enhance watershed planning and conservation [Bohn and Kershner, 2002; Houck, 2002]. The maximum entropy model of SEP presented here is a prime example of an assessment tool that could be used for determining the relative importance of environmental variables in streambank erosion processes, watershed planning applications such as prioritizing sites for management, and for many other prospective applications related to stream restoration design such as determining the restoration potential of sites. This type of modeling framework has been suggested by restoration scientists as an important component for improved management of water resources [Wohl et al., 2005], and we believe that Bayesian approaches like maximum entropy are promising avenues for further development of assessment tools due to their robust approach to modeling spatial distributions of environmental phenomena [Phillips et al., 2006; Dudik et al., 2007; Pearson, 2007; Beane, 2010]. Such models could help to bridge the gap between restoration science and practice, ultimately improving the success of watershed management.

\section{Acknowledgments}

The authors thank the National Fish and Wildlife Foundation, Canaan Valley Institute, the Chesapeake Bay Trust, the National Oceanic and Atmospheric Administration, FishAmerica Foundation, Cacapon and Lost Rivers Land Trust, the West Virginia University (WVU) Environmental Research Center, and the WVU Natural Resource Analysis Center for funding and logistic support. Also, thanks to a large number of local landowners for participating in this project, and to Aaron Maxwell, Dr. George Merovich, Dr. 
Steven Kite, Dr. Charles Yuill, Walter Veselka, Gabriel Strain, Larry Pitchford, Dr. Andrew Coleman, Patricia Faulkner, Cameron Eddy, Ishwar Dhami, and Jerry Yates for additional assistance.

\section{References}

Agouridis, C.T., S.R. Workman, R.C. Warner, and G.D Jennings (2005), Livestock grazing management impacts on stream water quality: a review, Journal of American Water Resources Assocociation 41, 591-606.

Agterberg, F.P., G.F. Bonham-Carter, Q. Cheng, and D.F. Wright (1993), Weights of evidence modeling and weighted logistic regression for mineral potential mapping in Computers in Geology, 25 Years of Progress, edited by John C. Davis, pp. 13 - 32, Oxford University Press, Oxford.

Aspinall, R. (1992), An inductive modeling procedure based on Bayes' theorem for analysis of pattern in spatial data, International Journal of Geographical Information Systems 6, 105-121.

Beane, N.R. (2010), Using environmental and site-specific variables to model current and future distribution of red spruce (Picea rubens Sarg.) forest habitat in West Virginia, Ph.D. Dissertation, Division of Forestry and Natural Resources, West Virginia University.

Bloom, A.L. (1998), Geomorphology: A Systematic Analysis of Late Cenozoic Landforms $3^{\text {rd }}$ edn., Prentice Hall, New Jersey.

Bohn, B.A., and J.L. Kershner (2002), Establishing aquatic restoration priorities using a watershed approach, Journal of Environmental Management 64, 1-9

Boleneus, D., G., J. Raines, A. Causey,T. Bookstrom, T. Frost, and P. Hyndman (2001), Assessment method for epithermal gold deposits in northeast Washington State using weights-of-evidence GIS modeling, USGS report 01-501.

Constantz, G., N. Ailes, and D. Malakoff (1995), Portrait of a river: the ecological baseline of the Cacapon River, Cacapon Institute, High View, WV. 
Dahal, R.K., S. Hasegawa, A. Nonomura, M. Yamanaka, T. Masuda, and K. Nishino (2008), GIS-based weights-of-evidence modelling of rainfall-induced landslides in small catchments for landslide susceptibility mapping, Environmental Geology 54, 311-324.

Doll, B.A., G.L. Grabow, K.R .Hall, J. Halley, W.A. Harman, G.D. Jennings, and D.E. Wise (2003), Stream Restoration: A Natural Channel Design Handbook, The North Carolina Stream Restoration Institute and the North Carolina Sea Grant, Raleigh, NC.

Dudik, M., S.J. Phillips, and R.E. Schapire (2007), Maximum entropy density estimation with generalized regularization and an application to species distribution modeling, Journal of Machine Learning Research 8, 1217-1260.

Ellis, J., D. Hughes, and A. Smith (2011), Sediment source assessments and establishing priorities for abatement, Proceedings of the 2011 Georgia Water Resources Conference, Athens, Ga

Evans, B.M., S.A. Sheeder, and D.W. Lehning (2003), A spatial technique for estimating streambank erosion based on watershed characteristics, Journal of Spatial Hydrology 3, 1-13.

Goetz, S.J. (2006), Remote sensing of riparian buffers: past progress and future prospects, Journal of the American Water Resources Association 42, 133-143.

Graf, W.L. (1984) A probabilistic approach to the spatial assessment of river channel instability, Water Resources Research 20, 953-962.

Harmel, R.D., C.T. Haan, and R.C. Dutnell (1999), Evaluation of Rosgen's streambank erosion potential assessment in northeast Oklahoma. Journal of the American Water Resources Association $35,113-121$.

Hasset, B., M. Palmer, E. Bernhardt, S. Smith, J. Carr, and D. Hart (2005), Restoring watersheds project by project: trends in Chesapeake Bay tributary restoration, Frontiers in Ecological Environments $3,259-267$.

Heede, B.H. (1980), Stream dynamics: an overview for land managers, USDA Forest Service, Rocky Mountain Forest and Range Experiment Station, General Technical Report RM-72. 
Hernandez, P.A., C.H. Graham, L.L. Master, and D.L. Albert (2006), The effect of sample size and species characteristics on performance of different species distribution modeling methods, Ecography 29, 773-785

Houck, O.A. (2002), The Clean Water Act TMDL Program: Law, Policy, and Implementation $2^{\text {nd }}$ edn., Environmental Law Institute, Washington D.C.

Hu, J., and Z. Jiang (2010), Predicting the potential distribution of the endangered Przewalski`s gazelle, Journal of Zoology 282, 54-63.

Hupp, C.R., J.M. Richter, R.K. Peet, and P.A. Townsend (2009), Bank erosion along the dam-regulated lower Roanoke River, North Carolina, Management and Restoration of Fluvial Systems with Broad Historical Changes and Human Impacts: Geological Society of America Special Paper $451,97-108$.

Jaynes, E.T. (1989), Papers on probability, statistics, and statistical physics, Kluwer press, Dordrecht.

Kondolf, G.M., and E.R. Micheli (1995), Evaluating stream restoration projects, Environmental Management 19, 1-15.

Lave, R., M. Doyle, and M. Robertson (2010), Privatizing stream restoration in the U.S., Social Studies of Science 40, 677-703.

Luppi, L., M. Rinaldi, L.B. Teruggi, S.E. Darby, and L. Nardi (2008), Monitoring and numerical modeling of riverbank erosion processes: a case study along the Cecina River (central Italy), Earth Surface Processes and Landforms, DOI 10.1002/esp.1754.

Manning, C. and H. Schutze (1999), Foundations of Statistical Natural Language Processing. MIT, Cambridge, MA.

Merritt, W.S., R.A. Letcher, and A.J. Jakeman (2003), A review of erosion and sediment transport models, Environmental Modelling and Software 18, 761-799.

Micheli, E.R., and J.W. Kirchner (2002), Effects of wet meadow riparian vegetation on streambank erosion two: Measurements of vegetated bank strength and consequences for failure mechanics, Earth Surface Processes and Landforms 27, 687-697. 
Moghaddam, M.G.R., M. Khyyam, M. Ahmadi, and M. Farajzadeh (2007), Mapping susceptibility landslide using the weight-of-evidence model: a case study in Merek Valley, Iran, Journal of Applied Sciences 7, 3342-3355.

Palmer M.A., D.D. Hart, J.D. Allan, and E. Bernhardt (2003), Bridging engineering, ecological, and geomorphic science to enhance river restoration: local and national efforts. Proceedings of a National Symposium of Urban and Rural Stream Protection and Restoration, EWRI World Water and Environmental Congress. American Society for Civil Engineers, Reston, VA.

Palmer M.A., and E.S. Bernhardt (2006), Hydroecology and river restoration: ripe for research and synthesis, Water Resources Research 42, 1-4.

Pearson, R.G. (2007), Species' distribution modeling for conservation educators and practitioners, Synthesis, American Museum of Natural History, New York, NY.

Pfankuch, D.J (1975), Stream reach inventory and channel stability evaluation. USDS Forest Service, Region 1, Missoula, MT.

Phillips, S.J., R.P. Anderson, and R.E. Schapire (2006), Maximum entropy modeling of species geographic distributions, Ecological Modelling 190, 231-259.

Pitchford, J.L. (2012) Stream restoration: site selection and project evaluation. Ph.D. Dissertation, Division of Forestry and Natural Resources, West Virginia University.

Regmi, N.R., J.R. Giadino, and J.D. Vitek (2010), Modeling susceptibility to landslides using the weight of evidence approach: western Colorado, USA, Geomorphology 115, 172-187.

Roni, P., T.J. Beechie, R.E. Bilby, F.E. Leonetti, M.M. Pollock, and G.R. Pess (2002), A review of stream restoration techniques and a hierarchical strategy for prioritizing restoration in pacific northwest watersheds, North American Journal of Fisheries Management 22, 1-20.

Rosgen, D. (1996), Applied River Morphology $2^{\text {nd }}$ edn., Wildland Hydrology, Fort Collins, CO. 
Rosgen, D.L. (1997), A geomorpholgical approach to the restoration of incised rivers. in Management of Landscapes disturbed by channel incision: Stabilization, rehabilitation, restoration edited by S. Y. Wang pp.12-22, Center for Computational Hydro Science and Engineering, Oxford, MS.

Rosgen, D.L. (1998), The Reference Reach-A Blueprint for Natural Channel Design, Proceedings of the American Society of Civil Engineers, Restoration of Wetlands and Rivers, Denver, CO.

Rosgen, D. (2001), Practical method of computing streambank erosion rate, Proceedings of the Seventh Federal Interagency Sedimentation Conference, Reno, NV.

Russel, G.D., C.P. Hawkins, and M.P. O’Neil (1997), The role of GIS in selecting sites for riparian restoration based on hydrology and land use, Restoration Ecology 5, 56-68.

Smith, S.M., and K.L. Prestegaard (2005), Hydraulic performance of a morphology-based stream channel design. Water Resources Research 41, 1-17.

Simon, A., A.J.C. Collison, and A. Layzell (2003), Incorporating bank-toe erosion by hydraulic shear into the ARS bank stability model: Missouri River, eastern Montana. Proceedings of the First Interagency Conference on Research in the Watersheds, USDA ARS, Benson, AZ, 70-76.

Simon, A., M. Doyle, M. Kondolf, F.D. Shields, B. Rhoads, and M. McPhillips (2007), Critical evaluation of how the Rosgen classification and associated 'Natural Channel Design' methods fail to integrate and quantify fluvial processes and channel response, Journal of the American Water Resources Association 43, 1117-1131.

Simon, A., M. Doyle, M. Kondolf, F.D. Shields, B. Rhoads, and M. McPhillips (2008), Reply to discussion by Dave Rosgen "Critical evaluation of how the Rosgen classification and associated 'Natural Channel Design' methods fail to integrate and quantify fluvial processes and channel responses", Journal of The American Water Resources Association 44, 782-792.

Strager, M.P., and R.S. Rosenberger (2006), Incorporating stakeholder preferences for land conservation: weights and measures in spatial MCA, Ecological Economics 57, 627-639. 
Strager, M.P., J.T. Anderson, J.D. Osbourne, and R. Fortney (2011), A three-tiered framework to select, prioritize, and evaluate potential wetland and stream mitigation banking sites, Wetlands Ecology and Management 19, 1-18.

USDA (2011), Soil Survey Geographic Database (SSURGO) for West Virginia.

Van Eps, M.A., S.J. Formica, T.L. Morris, J.M. Beck, and A.S. Cotter (2004), Estimating annual sediment loads from streambank erosion in the West Fork watershed, Arkansas Watershed Advisory Group, North Little Rock, AR.

Vitalis, K., and O. Manoliadis (2002), A two-level multicriteria DSS for landfill site selection using GIS: case study in western Macedonia, Greece, Journal of Geographic Information and Decision Analysis 6, 49-56.

West Virginia Geological and Economic Survey (2011), Statewide geologic map obtained from Mont Chateau Research Center, Morgantown, WV.

Winterbottom, S.J., and D.J. Gilvear (2000), A GIS-based approach to mapping probabilities of river bank erosion: Regulated River Tummel, Scotland, Regulated Rivers: Research and Management $16,127-140$.

Wohl, E., P.L. Angermeier, B. Bledsoe, G.M. Kondolf, L. MacDonnel, D.M. Merrit, M.A. Palmer, N.L. Poff, and D. Tarboton (2005), River restoration, Water Resources Research 41, 1-12.

Yuksel, A., R. Cundogan, and A.E. Akay (2008), Using remote sensing and GIS technology for erosion risk mapping of Kartalkaya Dam watershed in Kahramanmaras, Turkey, Sensors 2008, 48514865. 


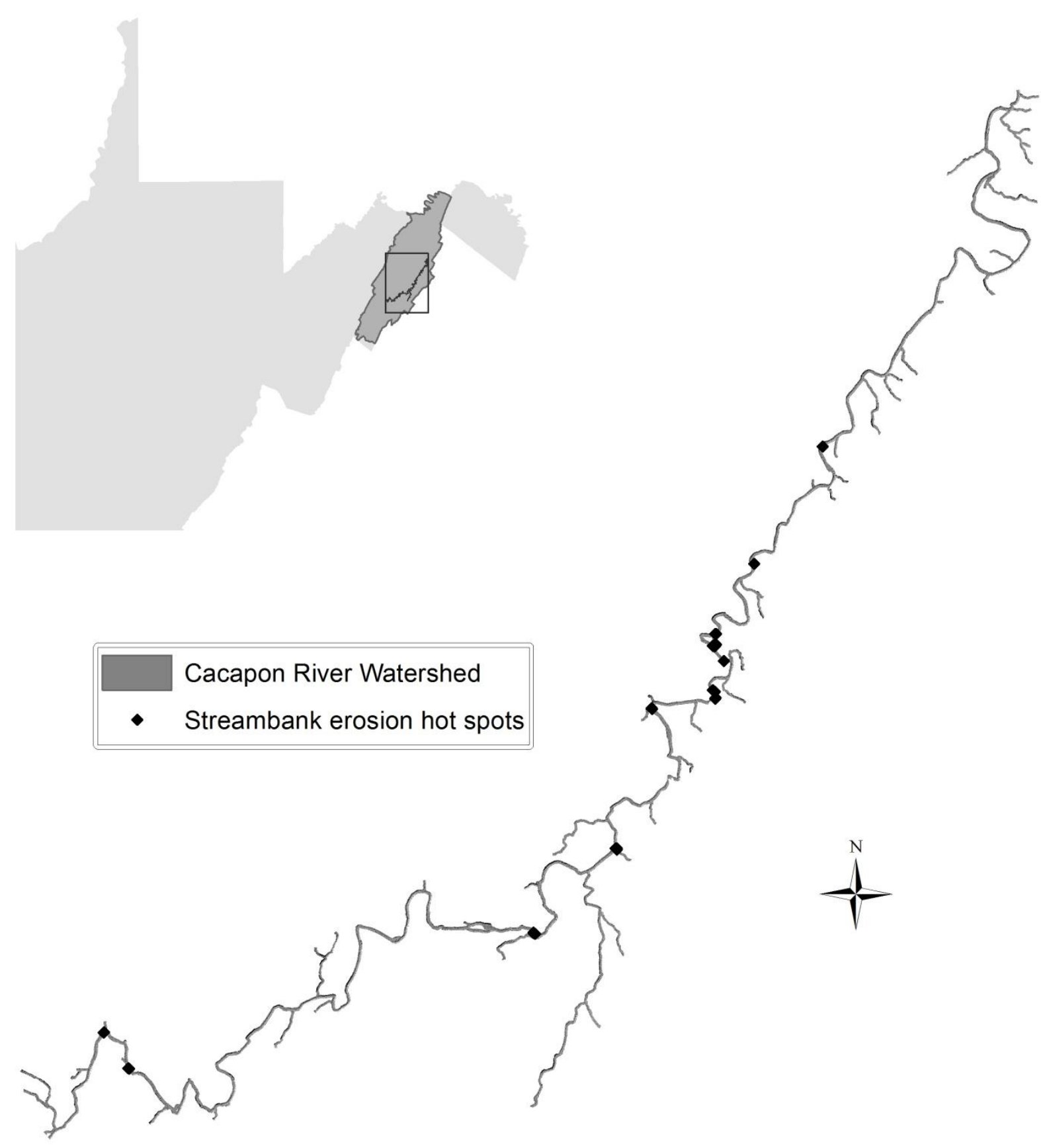

NAD 83 UTM 17N

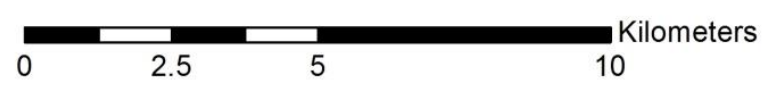

Figure 1. A portion of the Cacapon River Watershed, West Virginia where airborne light detection and ranging (LiDAR) was flown for development of a maximum entropy model of streambank erosion potential (SEP). Also shown are 29 target eroding areas (TEAs) for streambank erosion identified from 151 sites within the study area where streambank erosion rates were measured in $2010-2011$. 


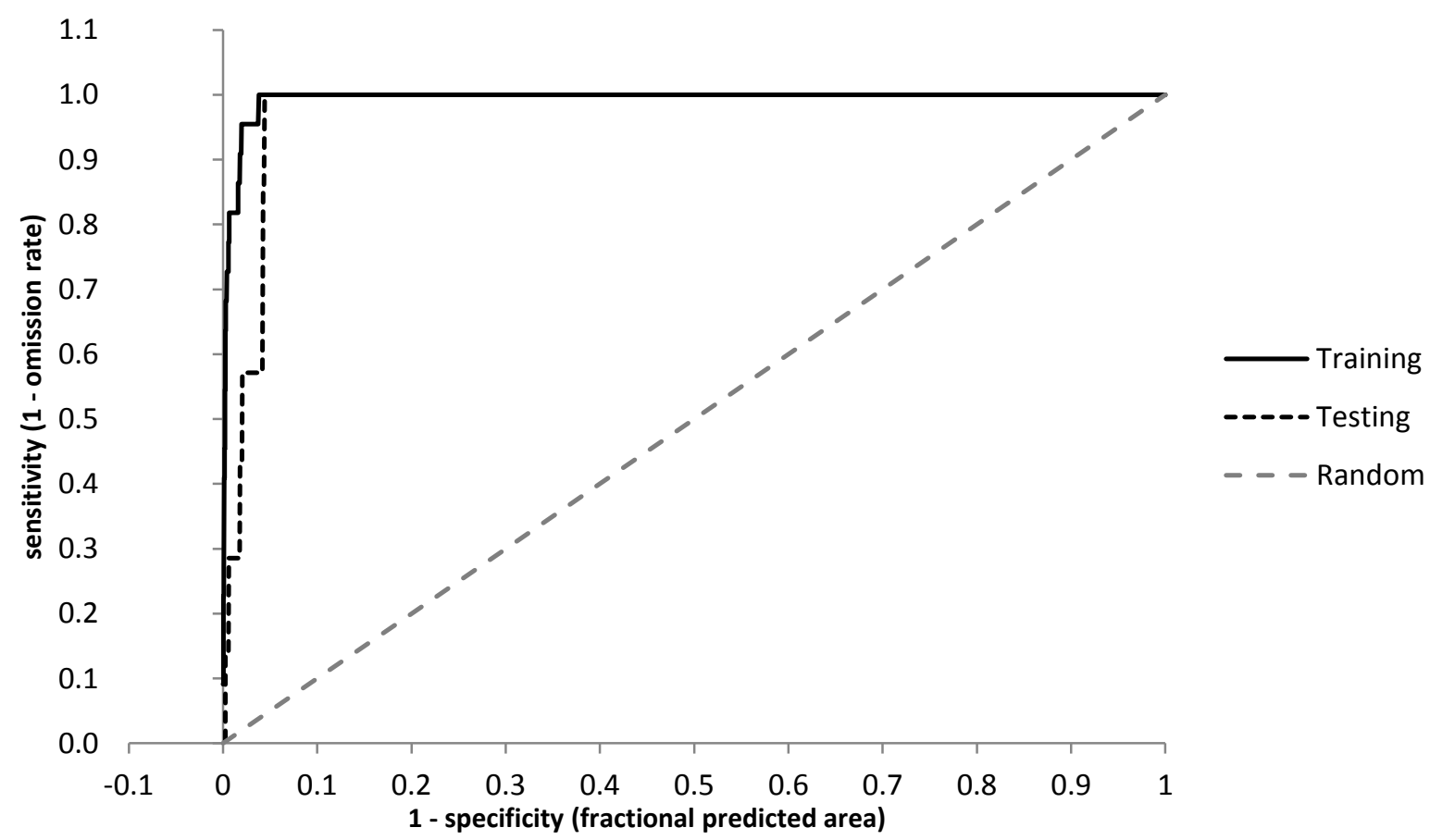

Figure 2. Threshold independent receiver operating characteristic curve (ROC) for maximum entropy representing one of 30 random partitions of occurrence records of target eroding areas (TEAs) generated using nine predictor variables. Sensitivity (1 - omission) is the proportion of presence records correctly predicted by the model and 1 - specificity is the proportion of the pixels in the study extent predicted to be TEAs. The average area under curve (AUC) for all model runs was $0.994(\mathrm{SE}=0.0005)$ indicating excellent model performance. Average test AUC for all model runs was 0.985 ( $\mathrm{SE}=0.002)$. 

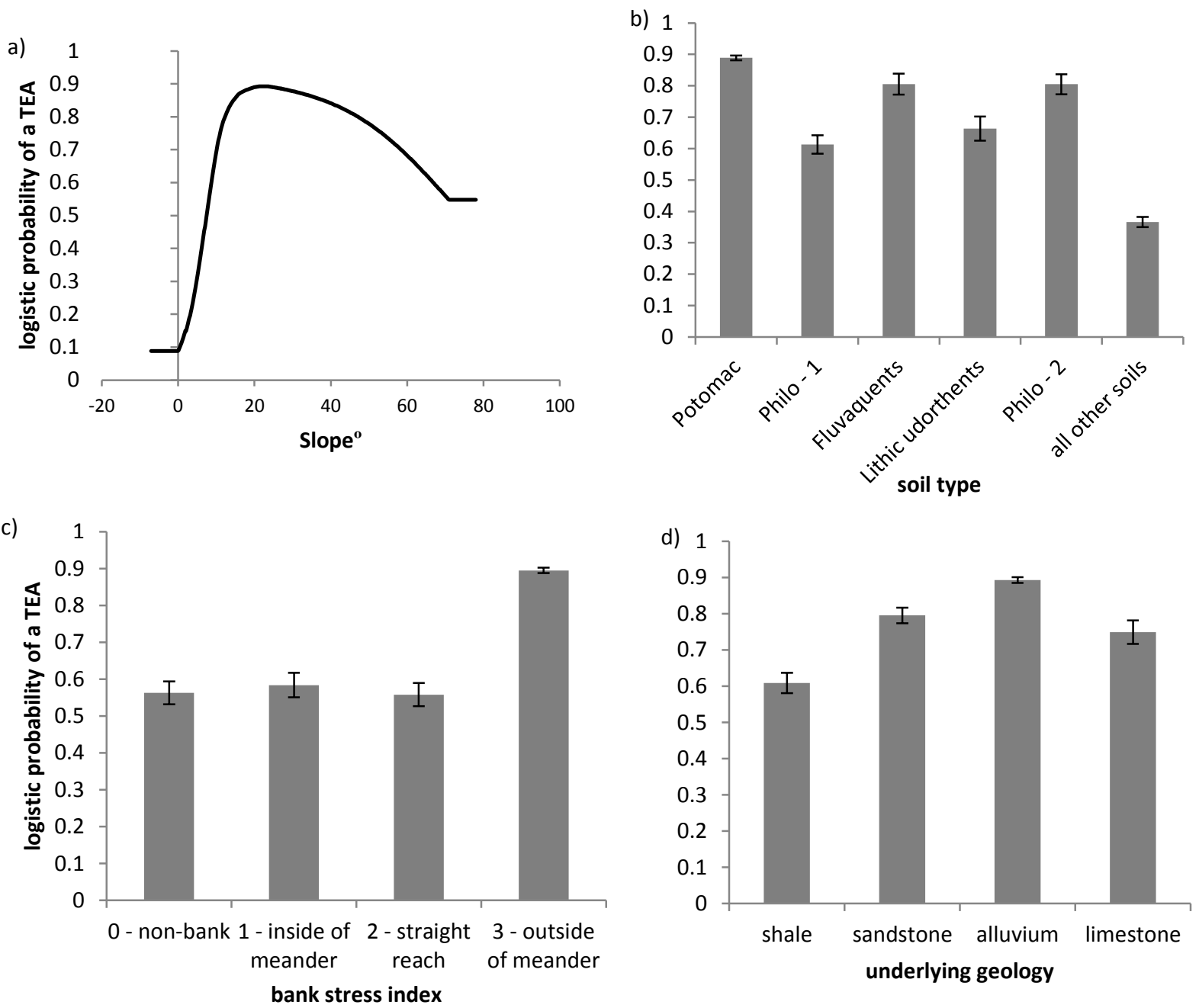

Figure 3. The influence of a) slope $\left({ }^{\circ}\right)$, b) bank stress index, c) soil type, and d) underlying geology on the logistic output (probability of presence) of a target eroding areas (TEAs). Each response curve shows the relation between each variable and the logistic probability of presence of a TEA when all other variables are held at their mean. 

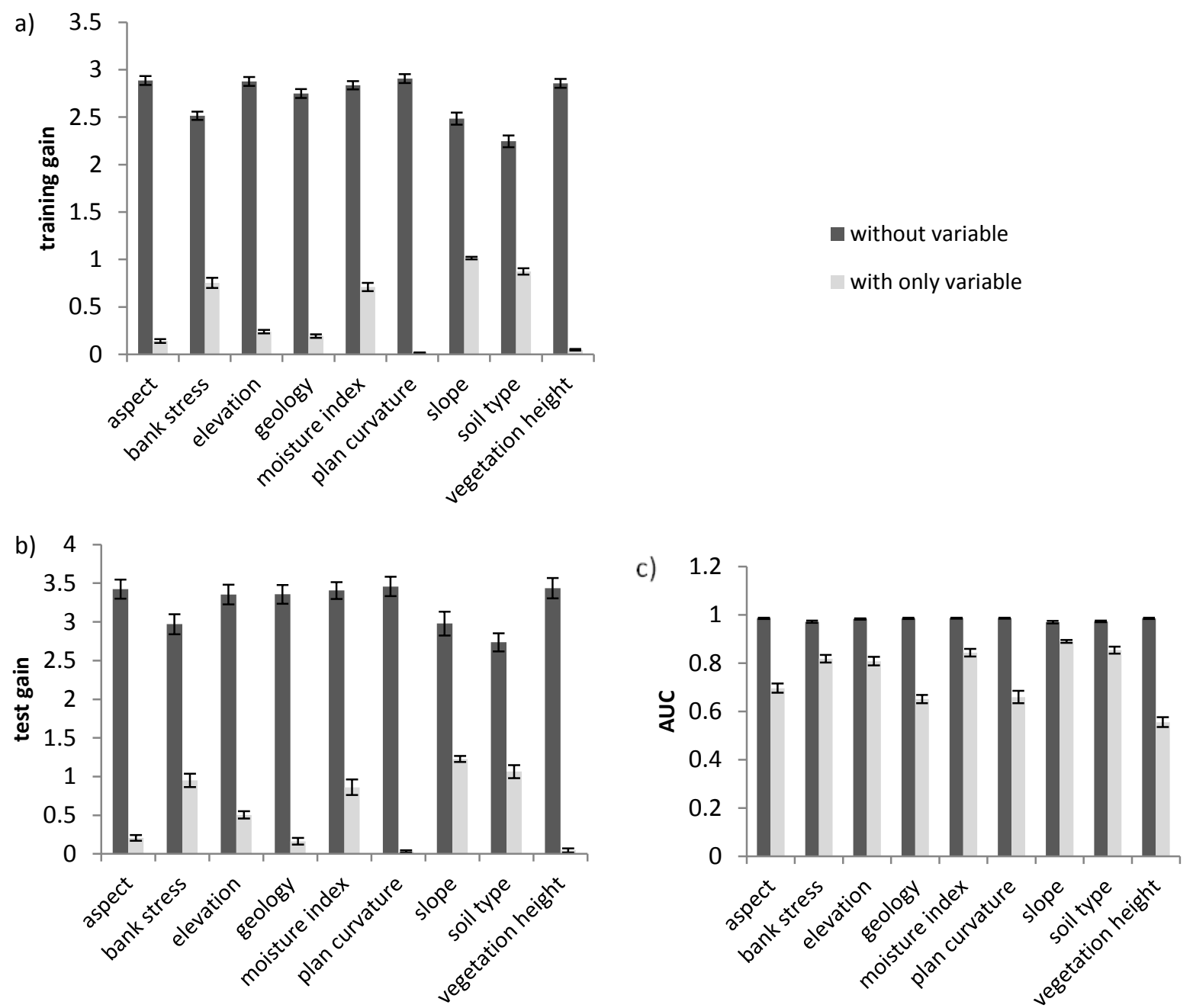

Figure 4. Results of jackknife analyses from 30 replicate maximum entropy model runs of target eroding areas (TEAs). These results show the relative importance of each variable when all other variables held at their mean and when used alone with respect to a) training gain, b) test gain, and c) Area Under Curve (AUC) values. Fluctuations in training and test gain represent changes to the coefficients that occur in each step of the maximum entropy algorithm in response to the addition or exclusion of environmental variables. 

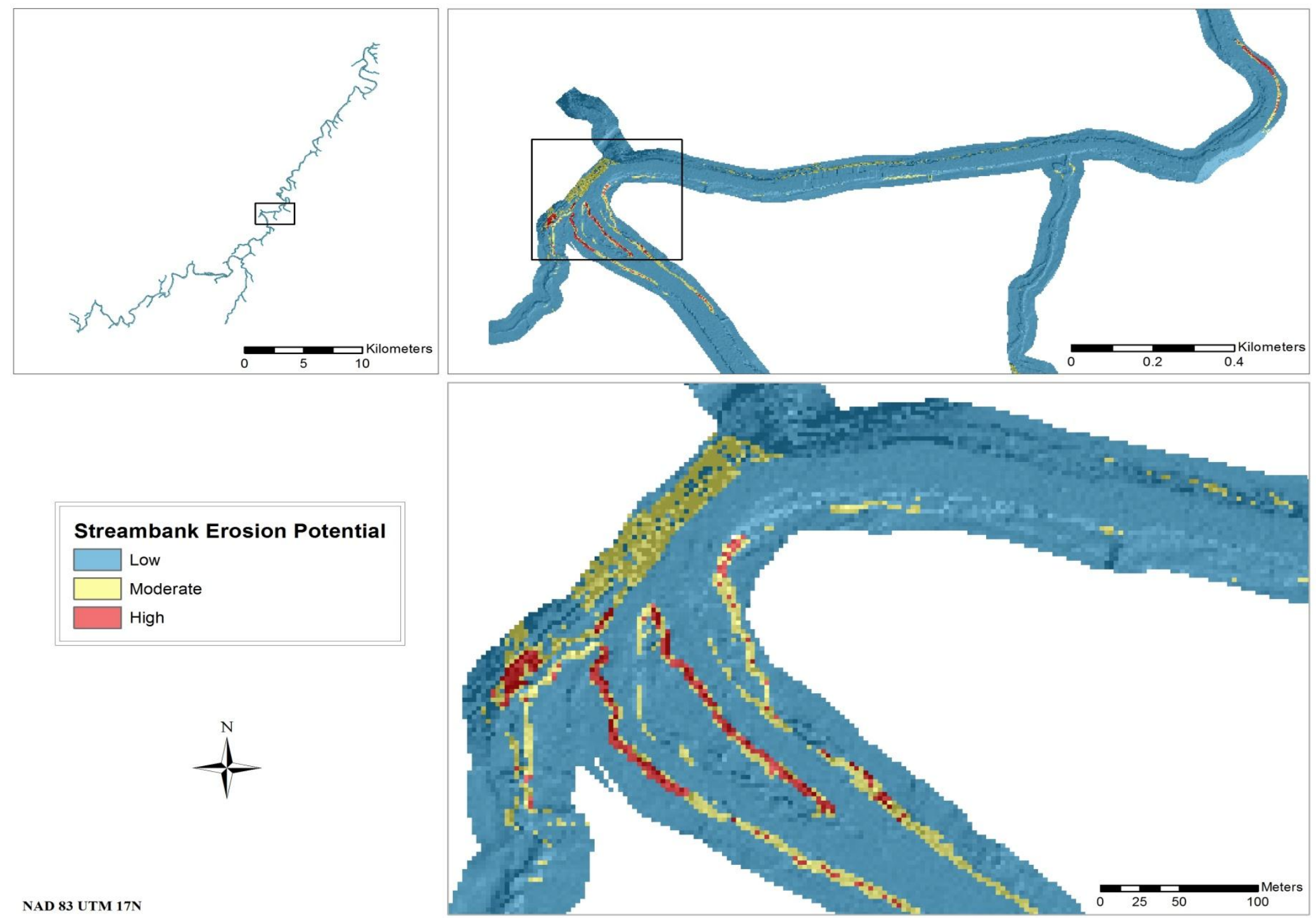

NAD 83 UTM 17N

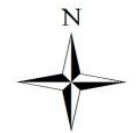

Figure 5. Logistic output of a maximum entropy model of streambank erosion potential (SEP) reclassified to represent three levels of SEP in a portion of the Cacapon River Watershed, West Virginia. Areas in the blue are below the minimum training presence $(\mathrm{MTP}=0.209)$ of target eroding areas (TEAs). The other two levels of SEP represent equal intervals of logistic model output greater than the MTP. 


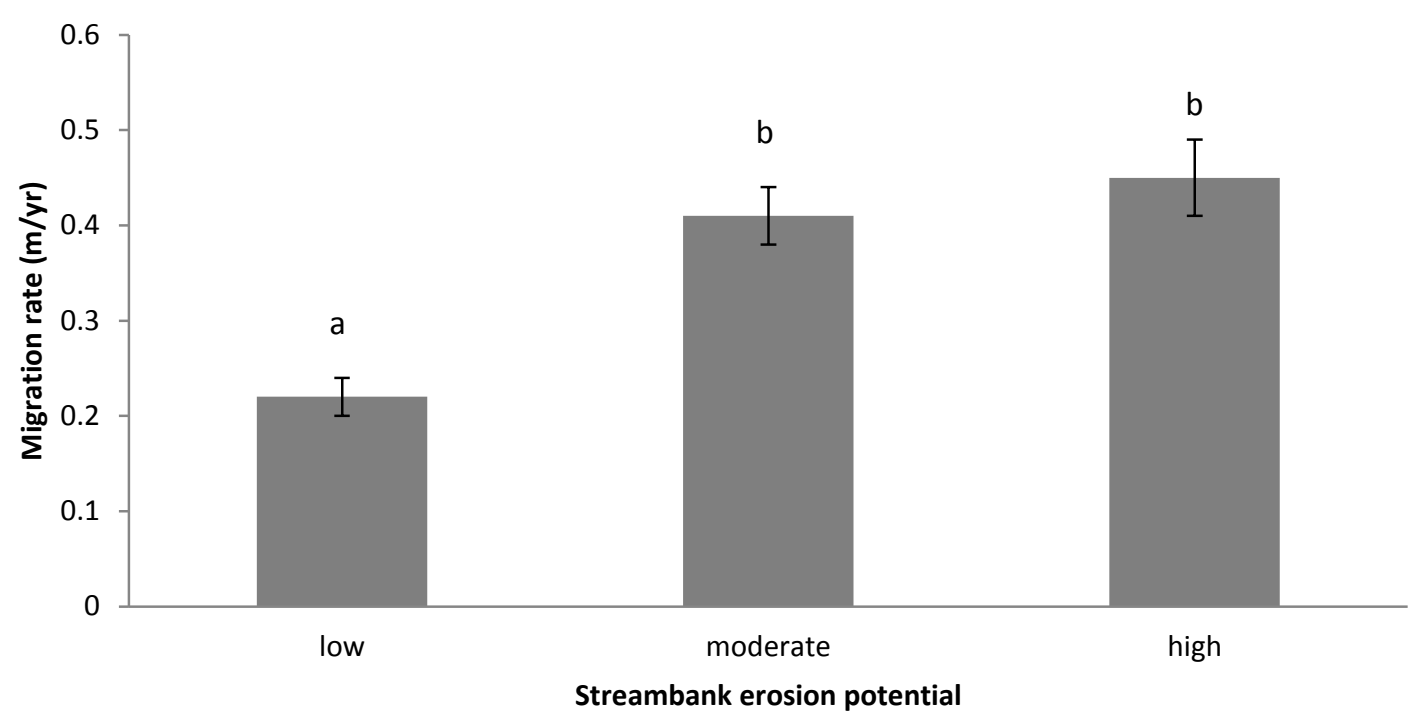

Figure 6. Streambank erosion potential (SEP) ratings (low, moderate, and high) and corresponding mean migration rates for 151 sites where streambank erosion rates were monitored for $2010-2011$. An Analysis of Variance (ANOVA) on the classification scheme derived from Maxent logistic output on 151 sites monitored in the Cacapon River Watershed, West Virginia revealed that the maximum entropy classification could distinguish between sites with low (a) versus moderate or high SEP (b). 
Table 1. Information about environmental variables used to create a model of streambank erosion potential (SEP) in the Cacapon River Watershed, West Virginia including the variable name, source, significance for modeling, geoprocessing steps, minimum values, maximum values, mean, and standard error (SE).

\begin{tabular}{|c|c|c|c|c|c|c|}
\hline Variable & Source & Significance & Geoprocessing & Min & Max & Mean (SE) \\
\hline Geology & WVGES & $\begin{array}{l}\text { Characteristics of underlying } \\
\text { geology }\end{array}$ & Converted geology "type" to raster & N/A & N/A & N/A \\
\hline Elevation & Bare earth DEM & Position in the watershed & $\begin{array}{l}\text { Converted multipoint LiDAR data to DEM using } \\
\text { 'IDW' interpolation. }\end{array}$ & 209 & 423 & $292(0.06)$ \\
\hline Slope & calculated & Steepness & $\begin{array}{l}\text { DEM used as input layer in 'Slope' tool in Surface } \\
\text { Analysis toolbox }\end{array}$ & 0 & 81 & $9.6(0.01)$ \\
\hline Aspect & calculated & Orientation, exposure & $\begin{array}{l}\text { DEM used as input layer in 'Aspect' tool in Surface } \\
\text { Analysis toolbox }\end{array}$ & 0 & 360 & $181(0.11)$ \\
\hline Curvature & calculated & Steepness, concavity, convexity & $\begin{array}{l}\text { DEM used as input layer in 'Curvature' tool in } \\
\text { Surface Analysis toolbox }\end{array}$ & -910 & 669 & $-0.2(0.02)$ \\
\hline Profile curvature & calculated & Steepness, concavity, convexity & $\begin{array}{l}\text { Selected as additional output for 'Curvature' tool in } \\
\text { Surface Analysis toolbox }\end{array}$ & -395 & 481 & $0.2(0.01)$ \\
\hline Plan curvature & calculated & Steepness, concavity, convexity & $\begin{array}{l}\text { Selected as additional output for 'Curvature' tool in } \\
\text { Surface Analysis toolbox }\end{array}$ & -514 & 378 & $0.0(0.01)$ \\
\hline Solar radiation & calculated & $\begin{array}{l}\text { Sub-aerial processes, freeze-thaw } \\
\text { cycling }\end{array}$ & $\begin{array}{l}\text { DEM used as input layer in 'Area Solar Radiation' } \\
\text { tool in Solar Radiation toolbox. Specified time } \\
\text { configuration was multiple days in a year: 5/16/2010 } \\
-5 / 15 / 2011\end{array}$ & 93,189 & $1,423,170$ & $\begin{array}{l}1,229,151 \\
(117)\end{array}$ \\
\hline Flow accumulation & calculated & $\begin{array}{l}\text { Run-off velocity, volume, potential } \\
\text { energy }\end{array}$ & $\begin{array}{l}\text { Flow direction raster used an input layer in 'Flow } \\
\text { Accumulation' tool in Hydrology toolbox. Flow } \\
\text { direction was created using DEM as input layer }\end{array}$ & 0 & $24,641,804$ & $\begin{array}{l}119,192 \\
(1,354)\end{array}$ \\
\hline Moisture index & calculated & Soil water content & $\begin{array}{l}\text { Created using the following equation in raster } \\
\text { calculator: } \ln (\text { flow accumulation }+1) /(\text { slope }+1)\end{array}$ & -4 & 17 & $0.0(0.00)$ \\
\hline Bank stress index & calculated & Shear stress & $\begin{array}{l}\text { Digitized polygons along stream channel to represent } \\
\text { low, medium, or high bank stress based on the ratio of } \\
\text { radius of curvature to stream channel width. } \\
\text { Converted polygons to raster }\end{array}$ & N/A & N/A & N/A \\
\hline Vegetation height & Vegetation DEM & Surcharge, buffer characteristics & $\begin{array}{l}\text { Subtracted vegetation DEM, created from } 1^{\text {st }}, 2^{\text {nd }} \text {, and } \\
3^{\text {rd }} \text { return multipoint LiDAR data from bare earth } \\
\text { DEM using raster calculator }\end{array}$ & -11 & 77 & $7.8(0.01)$ \\
\hline Soil type & SSURGO & Soil characteristics & Converted soil type polygons to a DEM & N/A & N/A & N/A \\
\hline Soil erodibility & SSURGO & Soil shear strength & $\begin{array}{l}\text { Created polygon layer containing soil erodibility for } \\
\text { each corresponding soil type and converted to raster }\end{array}$ & 0 & 0.4 & $0.2(0.00)$ \\
\hline
\end{tabular}


Table 2. Common thresholds and corresponding descriptions along with average fractional predicted area and omission rates for ten replicate runs of a maximum entropy model of streambank erosion potential (SEP).

\begin{tabular}{|c|c|c|c|c|c|c|}
\hline $\begin{array}{l}\text { Cumulative } \\
\text { threshold }\end{array}$ & $\begin{array}{l}\text { Logistic } \\
\text { threshold }\end{array}$ & Description & Fractional predicted area ${ }^{\mathrm{a}}$ & Training omission rate & Test omission rate ${ }^{b}$ & $P$ value $^{\mathrm{c}}$ \\
\hline 1.0 & 0.004 & Fixed cumulative value 1 & 0.379 & 0.000 & 0.000 & $1.30 \times 10^{-3}$ \\
\hline 5.0 & 0.025 & Fixed cumulative value 5 & 0.179 & 0.002 & 0.014 & $3.08 \times 10^{-5}$ \\
\hline 10.0 & 0.055 & Fixed cumulative value 10 & 0.107 & 0.002 & 0.042 & $1.78 \times 10^{-6}$ \\
\hline 25.1 & 0.209 & Minimum training presence & 0.041 & 0.000 & 0.110 & $3.09 \times 10^{-6}$ \\
\hline 38.9 & 0.394 & 10 percentile training presence & 0.015 & 0.088 & 0.238 & $4.40 \times 10^{-5}$ \\
\hline 26.5 & 0.221 & Equal training sensitivity and specificity & 0.034 & 0.035 & 0.143 & $1.69 \times 10^{-5}$ \\
\hline 31.3 & 0.297 & Maximum training sensitivity plus specificity & 0.030 & 0.009 & 0.143 & $5.25 \times 10^{-7}$ \\
\hline 26.7 & 0.245 & Equal test sensitivity and specificity & 0.051 & 0.056 & 0.029 & $4.58 \times 10^{-6}$ \\
\hline 27.8 & 0.259 & Maximum test sensitivity and specificity & 0.047 & 0.058 & 0.005 & $8.48 \times 10^{-8}$ \\
\hline 4.53 & 0.022 & Balance training omission, predicted area and threshold value & 0.189 & 0.000 & 0.000 & $1.16 \times 10^{-5}$ \\
\hline 18.0 & 0.117 & Equate entropy of thresholded and original distribution & 0.056 & 0.011 & 0.081 & $2.63 \times 10^{-6}$ \\
\hline
\end{tabular}

${ }^{a}$ The fractional predicted area represents the fraction of pixels within the study extent that correspond to each threshold value.

${ }^{\mathrm{b}}$ Training and test omission rates refer to the fraction of pixels containing an target eroding area (TEA) that fell outside the prediction.

${ }^{c}$ The one-sided $P$ values are from a binomial test on omission rates used to determine if the test points were predicted better than a random prediction within the same fractional predicted area. 
Table 3. Average percent contribution and permutation importance values for each predictor variable in the Maximum entropy distribution of target eroding areas (TEAs) for all 30 replicate model runs.

\begin{tabular}{llll}
\hline Variable & Variable name & Percent contribution (\%) & Permutation importance $^{\mathrm{a}}(\%)$ \\
\hline Slope & slope & 32.7 & 48.6 \\
Soil type & soil_type & 29.2 & 25.9 \\
Bank stress index & bank_stress & 20.6 & 9.1 \\
Geology & geology & 8.7 & 5.2 \\
Moisture index & moisture_index & 3.6 & 7.2 \\
Vegetation height & veg_ht & 2.6 & 0.9 \\
Elevation & elevation & 1.4 & 2.6 \\
Aspect & aspect2 & 1.2 & 0.4 \\
Plan Curvature & plan_curv & 0.1 & 0 \\
\hline
\end{tabular}

${ }^{a}$ Permutation importance values for each variable are determined by randomly permuting the variable values among the training points and quantifying the ensuing decrease in training AUC. 


\section{CHAPTER IV}

ESTIMATING STREAMBANK MIGRATION AND VOLUMETRIC SEDIMENT LOSS: A COMPARITIVE STUDY OF TRADITIONAL AND MODERN SURVEY TECHNIQUES

\footnotetext{
Jonathan L. Pitchford ${ }^{1}$, Adam Riley ${ }^{2}$, Michael Strager ${ }^{1}$, LianShin Lin ${ }^{3}$, and James T. Anderson ${ }^{1}$

${ }^{1}$ West Virginia University, Division of Forestry and Natural Resources, PO Box 6125, Morgantown, WV 26506-6125

*Corresponding Author e-mail: jpitchfo@mix.wvu.edu

${ }^{2}$ Natural Resource Analysis Center, West Virginia University

2009 Agricultural Sciences Building, Evansdale Dr. PO Box 6108, Morgantown, WV 26506-6108

${ }^{3}$ West Virginia University, Department of Civil and Environmental Engineering,

PO Box 6103, Morgantown, WV 26506-6125
}

Written in the style of:

Remote Sensing of Environment 


\section{Abstract}

As the role of stream and riparian management continues to expand, so does the need for accurate, high resolution estimation of streambank erosion. The role of laser scanning for estimating streambank migration and volumetric sediment loss has just begun to be explored, but could provide a way to accurately assess channel change with minimal time investment. The purpose of this study was to compare estimates of streambank migration and volumetric sediment loss derived from repeated erosion pin, streambank profile, and combined airborne and terrestrial LiDAR surveys along a degraded stream reach of the Cacapon River, West Virginia. Results showed that LiDAR derived estimates were larger and highly variable compared to estimates derived from erosion pin and streambank profile surveys, which more accurately represented change along the study reach. Major reasons for inflated LiDAR estimates were due to combining high resolution terrestrial LiDAR with relatively low resolution airborne LiDAR that could not effectively capture topographic features such as undercut banks. Although costprohibitive in some cases, repeated terrestrial LiDAR scans would likely circumvent these issues with higher point densities and better scan angles facilitating more accurate representation of streambank geometry, ultimately providing more accurate estimates of channel change.

Highlights

- A comparison of erosion pin, streambank profile, and LiDAR derived estimates of erosion was conducted.

- Results showed that erosion pin and streambank profile surveys yielded similar estimates, while LiDAR estimates were significantly larger.

- Major reasons for differences between methods were attributed to beam grazing and interpolation errors associated with LiDAR data that incorrectly inflated estimates. 


\section{Introduction}

The importance of assessing stream morphology and changes in stream channels over time is increasing with concurrent escalation of management initiatives aimed at reducing sediment and nutrient concentrations in impaired water bodies (Bernhardt et al., 2005; Kondolf \& Micheli, 1995; Roni et al., 2002; Resop \& Hession, 2010; Wohl et al., 2005). For example, the total maximum daily load program (TMDL) (The Clean Water Act, section 303d) and other similar pollution abatement strategies could benefit from periodic stream channel surveys to estimate sediment loads originating from streambanks (Resop \& Hession, 2010). Loss of land due to streambank erosion in urban and agricultural catchments is also of interest to both land managers and landowners where estimates of sediment loss from streambanks have environmental and economic consequences (Paterson et al., 1993; Agouridis et al., 2005).

Traditionally, estimating streambank erosion has been accomplished using stream channel cross-section surveys, streambank profile surveys, and erosion pins, all of which require considerable allocation of time and resources, yet provide low resolution estimates because of inadequate spatial coverage and data density (O’Neal \& Pizzuto, 2011). Additionally, these types of surveys can also result in error prone estimates due to physical disturbance to the streambank (Resop \& Hession, 2010).

Recently, remote sensing technologies have been integrated into streambank assessments improving survey accuracy and precision without the need for extensive field surveys (Goetz, 2006; Evans et al., 2003). For example, Laser Detection and Ranging (LiDAR) can be used to efficiently detect changes in surface topography over time, as indicated by accurate estimates of sea cliff erosion (Young et al., 2010) and riverbank erosion (Thoma et al., 2005; Resop \& Hession, 2010) using repeated LiDAR surveys. Comparative studies have shown that repeated airborne and terrestrial LiDAR surveys (ALS and TLS, respectively) yield highly correlated estimates of eroded material over time (Young et al., 2010), and that LiDAR derived estimates of volumetric sediment loss are less prone to extrapolation error than stream channel cross-sections, which are only conducted in selected locations along a continuum (O'Neal \& Pizzuto, 2011; Resop \& Hession, 2010). There have been no studies to date that have combined ALS and TLS to estimate streambank migration and volumetric sediment loss and compared these estimates 
with the results of repeated streambank profile and erosion pin surveys. A comparison of this nature will help identify the benefits and limitations of these methods for estimating streambank erosion, which could be used in watershed management applications.

The purpose of this study was to compare estimates of streambank migration and sediment loss derived from repeated erosion pin, streambank profile, and LiDAR surveys for an actively eroding stream reach in a central Appalachian watershed. To derive LiDAR estimates, we combined ALS and TLS to determine if the two methods used in conjunction would provide accurate estimates of streambank erosion.

2. Materials and methods

\subsection{Study area}

A reach was selected for study along the Cacapon River, within the Cacapon River Watershed in the Appalachian Mountains in the Ridge and Valley physiographic province (Figure 1). The watershed drains about 2,320 $\mathrm{km}^{2}$ within Hardy, Hampshire, and Morgan counties (Constantz et al., 1995), where the majority of land is forested (i.e., 79\%), with some agriculture (i.e., 19\%), and residential development (i.e., 2\%). The climate is humid continental, characterized by hot summers, cold winters, and average annual precipitation near $90 \mathrm{~cm}$ (Gillies, 2009). Field reconnaissance conducted in 2010 indicated that a $235 \mathrm{~m}$ reach was a good candidate site for this study as it was highly degraded and had high potential for future erosion based on Pfankuch stream reach inventory scores (Pfankuch, 1975) (Figure 1). The reach contained a single thread, gravel-bed channel with banks composed of Lithic Udorthents and Philo soils, which are comprised of silts and clays and have a bulk density ranging from $1.2-1.4 \mathrm{~g} / \mathrm{cm}^{3}$ (USDA, 2011). Land use buffering the selected reach was historically used for cattle grazing, but has not been grazed or used for hay production in recent decades, and is gradually becoming re-forested (Sandy White, personal communication). The selected reach is on the outside of a meander bend and had an average width of $36 \mathrm{~m}(\mathrm{SE}=2.0)$, an average streambank angle of $82^{\circ}(\mathrm{SE}=2.1)$ in 2010 , and median flow rates ranging from $2-34 \mathrm{~m}^{3} / \mathrm{s}$ during the study period (USGS, 2011). 


\subsection{Erosion pin and streambank profile surveys}

At the selected reach, eight survey sites, $30 \mathrm{~m}$ apart, were established using survey pins and the location of each site was recorded with a Garmin Inc. (Kansas City, Mo) Etrex Legend HCx geographic positioning system (GPS). Streambank migration rates were measured by inserting five, $122 \mathrm{~cm}$ long, $0.95 \mathrm{~cm}$ diameter reinforcing rods arranged in a vertical profile, $0.5 \mathrm{~m}$ apart, into the bank face using a hammer until almost flush (Luppi et al., 2008; Hupp et al., 2009 ). Location of erosion pins and pin length exposed were recorded during each survey. The total cost of erosion pins was $\$ 150$, and it took approximately eight person-hours to install fifty erosion pins in the reach.

Streambank profile surveys were also conducted at each site by establishing a benchmark in the lower bank area (Rosgen, 1996; Van Eps et al., 2004). Surveys were conducted using a level survey rod anchored to a tripod placed directly adjacent to the upstream side of the benchmark (Figure 2). The horizontal distance from the survey rod to the streambank was recorded every $0.15 \mathrm{~m}$ from the benchmark to the top of the bank using a Bosch ${ }^{\mathrm{TM}}$ DLR130 laser distance measurer. Erosion pins established at each survey location were used as reference points for profiles. The total cost of this method was approximately $\$ 400$, which includes the cost of the Bosch ${ }^{\mathrm{TM}}$ DLR130 laser distance measurer, eight 45.7 $\times 1.9 \mathrm{~cm}$ reinforcing rods used as toe pins, a heavy-duty aluminum tripod, and Crain ${ }^{\circledR}$ rectangular-oval shaped telescoping leveling/measuring rod. It took approximately four person-hours to conduct all eight surveys in the reach. Erosion pin and streambank profile surveys were conducted at all locations on the same days of each survey year (i.e., 7/1/2010 and 6/29/2011).

\subsection{LiDAR surveys}

Airborne LiDAR was flown on April 22, 2010 by the West Virginia University Natural Resource Analysis Center (WVUNRAC) at approximately 1,676 m above ground level at an average speed of 135 knots using the following parameters: pulse rate frequency of $70 \mathrm{kHz}$, scan frequency of $30 \mathrm{~Hz}$, and scan angle of $18^{\circ}\left(36^{\circ}\right.$ full field of view). The scanner used for data collection was an Optech Inc. (Ontario, Canada) ALTM3100, which fired up to 100,000 laser pulses per second with an accuracy within $15 \mathrm{~cm}$ of 
the vertical axis, with at least one shot per square meter with four vertical returns. Sensors for LiDAR collection included Geographic Positioning System (GPS), Inertial Measurement Unit (IMU) compensation, and laser ranging mounted in a Piper Navajo twin engine aircraft which enabled production of highly accurate and precise terrain mapping of the study area. Terrestrial LiDAR was also conducted by WVUNRAC on November 11, 2011 using a Faro® (Lake Mary, Florida) Photon80 LS terrestrial LiDAR scanner established on the opposite bank, 25 - 35 m from the target bank. A total of six scans were conducted at $50 \mathrm{~m}$ intervals to obtain adequate coverage of the streambank, and were linked together using registration spheres, which were located in the upstream and downstream field of view in each scan. The scanner fired up to 120,000 pulses per second with a beam divergence of $0.16 \mathrm{mrad}$ $\left(0.009^{\circ}\right)$ and average point spacing of $1 \mathrm{~cm}$ with an accuracy $\pm 2 \mathrm{~mm}$ within $25 \mathrm{~m}$. The total cost of the ALS and TLS data was $\$ 13,000$ (i.e., $\$ 10,000$ for ALS and $\$ 3,000$ for the TLS), which included data collection and processing.

Both airborne and terrestrial LiDAR were geo-rectified and post-processed to remove man-made structures and vegetation in creation of comparable bare earth models. Ground models were converted to a Log ASCII Standard (LAS) files, which were used to create a digital elevation models (DEMs) in ESRI® ArcGIS ${ }^{\mathrm{TM}} 10.0$ by converting LAS files to multipoint files using the 'LAS to multipoint' tool in the 3D Analyst Conversion toolbox. Raster data sets were created from multipoint files using the Inverse Distance Weighted ('IDW') interpolation tool in the Spatial Analyst toolbox, specifying a power of two and an output cell size of $1 \mathrm{~m}$ for airborne data and $0.1 \mathrm{~m}$ for terrestrial data.

\subsection{Estimates of streambank migration and volumetric sediment loss}

To calculate streambank migration with erosion pins, the change in pin length between subsequent surveys was calculated for each pin, and was averaged for each survey site. For streambank profile surveys, lateral change was measured every $0.15 \mathrm{~m}$ between profiles (Resop \& Hession, 2010) for each year and averaged to determine streambank migration for each survey site. To calculate a LiDAR derived estimate of streambank migration, streambank profiles extracted from ALS were compared to 
profiles extracted from TLS. Profiles were created from bare earth DEMs in ESRI® ArcMap ${ }^{\mathrm{TM}} 10.0$ for ALS and TLS using the 'Interpolate Line' tool in the 3D Analyst toolbar (Figure 3). The data for each interpolated profile were exported and used to create plotted profiles for 2010 and 2011, and the lateral change was measured every $0.15 \mathrm{~m}$ between profiles (Resop \& Hession, 2010) for each year and averaged to determine migration for each survey site. Positive values were used to represent degradation and negative values represent aggradation for migration data.

To calculate volumetric sediment loss, erosion pin and profile survey coordinates were imported into ESRI® $\operatorname{ArcMap}^{\mathrm{TM}} 10.0$ and a line was digitized between points to represent streambank profiles for each survey method using 'Point Snapping' to minimize error. Polygons were digitized to represent soil loss and soil gain between subsequent surveys for each survey method using 'Point' and 'Vertex Snapping,' to minimize error, and the area of each digitized polygon was calculated using the 'Calculate Geometry' function. Net soil loss was calculated for each survey site by summing sediment loss and gain to obtain an estimate of change in $\mathrm{m}^{2}$. Average sediment loss for each method was extrapolated to the reach by multiplying the length of the delineated streambank (i.e., $235 \mathrm{~m}$ ) by average sediment loss to derive a volumetric estimate for each method. To calculate volumetric sediment loss for repeated LiDAR surveys, the 'Cut Fill' tool in the 3D Analyst toolbox was used, specifying the 'before' surface as the ALS and the 'after' surface as the TLS. The output of this tool was a raster data set with an associated attribute table that contained volumetric change between DEMs and the corresponding number of $1 \times 1 \mathrm{~m}$ cells that experienced "Net Gain," "Net Loss," or remained "Unchanged" between survey periods. Volumetric change was summed over all the cells representing the streambank to calculate total estimated volumetric change.

\subsection{Data Analysis}

We conducted a one-way Analysis of Variance (ANOVA) using survey method (i.e., erosion pins, streambank profiles, and LiDAR) as the independent variable and normally distributed streambank migration (m) as the dependent variable for the eight sites where streambank erosion rates were quantified 
from 2010 - 2011 to test the null hypothesis that streambank migration estimates were the same among survey methods. We used two sets of values to represent erosion pin readings. The first set excluded pins that were lost between surveys (Veihe et al., 2011), and the second used a conservative value of $0.61 \mathrm{~m}$ for pins that were lost between surveys (Zaimes et al., 2008). Sites that experienced loss of benchmarks for streambank profile surveys were excluded from statistical tests. A significant ANOVA was followed with a Tukey's Honest Significant Difference (HSD) post hoc test to determine which methods were significantly different from one another. Significance for all tests was set at the $\alpha=0.05$ level.

Comparisons of volumetric change between survey methods for the reach were evaluated graphically.

\section{Results}

Average streambank migration calculated from repeated erosion pin surveys excluding lost pins was $0.43 \mathrm{~m}(\mathrm{SE}=0.06)$, and ranged from $0.29-0.69 \mathrm{~m}$ among the eight survey sites (Table 1; Figure 4). Average migration calculated with assigned values to lost pins was $0.61 \mathrm{~m}$, and ranged from $0.49-0.80$ $\mathrm{m}$. Average migration was estimated to be $0.21 \mathrm{~m}(\mathrm{SE}=0.07)$ using repeated streambank profile surveys, and ranged from $0.01-0.37 \mathrm{~m}$. Average streambank migration calculated from repeated LiDAR surveys was estimated to be $2.31 \mathrm{~m}(\mathrm{SE}=0.75)$, and ranged from $-0.09-6.09 \mathrm{~m}$ along the reach. Statistical tests detected a difference among methods $\left(F_{2,17}=5.1 ; P<0.01\right)$ as similar estimates derived from erosion pin and streambank profile surveys were smaller than LiDAR derived estimates $(P<0.05)$.

Total volumetric sediment loss estimated from repeated erosion pin and streambank profile surveys was $149.39 \mathrm{~m}^{3}$ and $136.63 \mathrm{~m}^{3}$, respectively (Figure 5). Volumetric analyses of LiDAR surveys indicated that of the $2,3141 \times 1 \mathrm{~m}$ cells, 934 experienced sediment gain totaling $569.6 \mathrm{~m}^{3}, 1,358$ cells experienced sediment loss totaling $919.8 \mathrm{~m}^{3}$, and 22 cells experienced no change. The overall net sediment loss from volumetric analyses was $323.2 \mathrm{~m}^{3}$ where the majority of soil loss was concentrated at the upstream end of the reach within the first $100 \mathrm{~m}$ where 579 cells experienced an estimated net sediment loss of $232 \mathrm{~m}^{3}$ (Figure 6). Small areas of sediment accretion were noted at the downstream end of the reach along the toe of the bank including an area encompassing 83 cells that experienced a net gain 
in sediment of $93 \mathrm{~m}^{3}$. Ten of the fifty erosion pins in the reach (i.e., 20\%) and three of eight toe pins (i.e., $37.5 \%$ ) used as benchmarks for streambank profile surveys were lost between surveys including all pins at one site in the upstream portion of the reach where LiDAR surveys indicated that sediment losses were heaviest.

\section{Discussion}

These results clearly show that LiDAR derived estimates of streambank migration were much larger and contained more variability than estimates derived from erosion pins and streambank profiles, which yielded similar estimates with low standard error. Such large differences are most likely the result of interpolating profiles from low density point data (O’Neal \& Pizzuto, 2011) as ALS had a point spacing of $1 \mathrm{~m}$, and was therefore unable to effectively represent detailed surface topography of the streambank (Figure 7). Also, the ability of LiDAR to capture unique features such as undercuts is heavily dependent on scan angle (Large \& Heritage, 2009). In cases where scanner position is not optimal for capturing streambank geometry, beam grazing errors occur (Charlton et al., 2009; Young et al., 2010), which can be propagated by interpolating profiles from error ridden surface data (Heuvelink, 1998; O’Neal \& Pizzuto, 2011). Beam grazing errors are highest when the scanner is positioned perpendicular to the target surface, and grazing errors increase with increases in slope of the target surface (Young et al. 2010). High variability among LiDAR derived migration estimates within the reach indicates that scan angle, thus the amount of beam grazing errors, varied in ALS along the study reach where some sites were more accurately captured than others. Terrestrial LiDAR could effectively capture streambank surface geometry because the scanning unit was positioned on the ground along the opposite streambank resulting in consistently better scan angles for capturing unique features of the bank face. Terrestrial LiDAR surveys also had much higher point density with lower point spacing (i.e., $1 \mathrm{~cm}$ ), which was used to generate a higher resolution bare earth model that more accurately depicted streambank topography. Thus, combining error prone ALS that generalized streambank geometry with detailed TLS that more effectively represented complex streambank geometry, resulted in over-estimation of streambank 
migration. Repeated TLS would be more likely to provide an accurate estimate of streambank migration for a given reach (Resop \& Hession, 2010; Young et al. 2010; O’Neal \& Pizzuto, 2011) than estimates derived from a combination of ALS and TLS.

Although less important, another confounding factor in this comparison is erosion and toe pin loss, which may have introduced bias in erosion pin and profile estimates. In studies that use erosion pins to assess change, areas where pin loss occurs are excluded from study (Veihe et al., 2011), or are assigned a value to represent a proportion of the pin length (Zaimes et al., 2008). Using an assigned value for lost erosion pins increased our estimate of streambank migration and more likely approaches reality. However, bias is still present in these data because actual migration at lost pin locations is not known. This is clearly a problematic aspect of traditional surveys that indicates traditional methods may not be reliable along streambanks that are undergoing high rates of change.

A final factor that may have influenced the results of this comparison is temporal error. Erosion pin and streambank profile surveys were conducted in the early summer of 2010 and 2011, while LiDAR data collection encompassed a larger time period (i.e., 4/2010 - 11/2011). A moderately-sized flow event reaching a peak discharge of $85 \mathrm{~m}^{3} / \mathrm{s}$ occurred in September of 2011 (USGS, 2011) after erosion pin and profile surveys were completed for the year that resulted in the loss of several toe pins from the reach in addition to pin loss presented in the results of this study. The effects of this particular flood on streambank migration and sediment loss were not quantified as erosion pin and profile surveys were not conducted following the flood event; however, five flood events of larger magnitude occurred from 11/2010 - 6/2011 (USGS, 2011), and any changes occurring during this time period were accounted for using all survey methods. Thus, it is unlikely that changes occurring during one, moderately-sized flow event could account for the magnitude of differences observed as average estimated streambank migration derived from LiDAR was more than five times higher than estimates derived from traditional surveys. Based on the appearance of streambank profiles derived from low point density ALS, and problems associated with unfavorable scan angle and beam grazing (Large \& Heritage, 2009; Young et al., 2010), 
interpolation errors (O’Neal \& Pizzuto, 2011) are likely responsible for the magnitude of difference between estimates.

Similar estimates among erosion pin and streambank profile surveys indicated that these methods most accurately quantified streambank migration and volumetric change along the study reach. Both survey methods were inexpensive and worked well together because erosion pins provided reference points for profiles, and because two estimates of sediment loss were obtained at each survey location. However, neither method was reliable for long-term monitoring as pin loss became problematic along the dynamic reach monitored in this study. Estimates of sediment loss using both survey methods also relied on interpolation between point measurements and extrapolation of point measurements to estimate change over the continuum, which are potential sources of error (O’Neal \& Pizzuto, 2011; Resop and Hession, 2010). Extrapolation error is problematic because changes occurring between survey locations are not accounted for in estimates. Although the effect of extrapolation is likely swamped out by interpolation error of LiDAR data in this study, extrapolation error can be an important consideration in some situations. Along reaches that contain highly variable erosion rates, change detection using LiDAR would allow changes to be quantified over the continuum. Volumetric analyses similar to that used in this study could be used to quantify sediment loss and gain for a set of grid cells within a defined extent where assessment of relative stability could be easily conducted (Figure 8). Ideally, application of this approach with repeated, high resolution TLS could be used for change detection, and for assessment of relative stability in a given reach. Assessment of relative stability along a continuum could help to inform restoration design as target areas for management could be readily identified.

\section{Conclusions}

Overall, these results suggest that combining airborne and terrestrial LiDAR data sets is not the best way to quantify topographic change in streambanks. Problems associated with beam grazing and interpolation errors can result in inaccurate estimation of streambank erosion (O’Neal \& Pizzuto, 2011), 
which is exacerbated if extrapolated to a segment- or watershed- scale to estimate sediment loads for TMDL programs (Resop and Hession 2010). For short-term monitoring, erosion pins and streambank profile surveys used together can provide a coarse, yet inexpensive estimate of streambank migration and volumetric sediment loss. Although expensive, the most accurate method for estimating change in streambanks is likely through repeated TLS (O’Neal \& Pizzuto, 2011; Resop \& Hession, 2010; Young et al., 2010), which could capture unique features such as undercut banks with high data point density and consistent scan angles. Although there is considerable initial cost, the ability of TLS to accurately capture high resolution data is unparalleled (O’Neal \& Pizzuto, 2011; Resop \& Hession, 2010) and minimal time investment in data collection likely makes this survey method superior to most other available survey methods.

\section{Acknowledgments}

The authors thank the National Fish and Wildlife Foundation, Canaan Valley Institute, the Chesapeake Bay Trust, the National Oceanic and Atmospheric Administration, FishAmerica Foundation, Cacapon and Lost Rivers Land Trust, the West Virginia University (WVU) Environmental Research Center, and the WVU Natural Resource Analysis Center for funding and logistic support. Also, thanks to local landowners for participating in this project, and to Aaron Maxwell, Dr. George Merovich, Dr. Steven Kite, Dr. Charles Yuill, Walter Veselka, Gabriel Strain, Larry Pitchford, Dr. Andrew Coleman, and Jerry Yates for additional assistance.

\section{References}

Agouridis, C.T., Workman, S.R., Warner, R.C. \& Jennings, G.D (2005). Livestock grazing management impacts on stream water quality: a review. Journal of American Water Resources Association, 41, 591-606.

Bernhardt, E., Palmer, M., Allan, J., Alexander, G., Barnas, K., Brooks, S., Carr, J., Clayton, S., Dahm, C., Follstad-Shah, J., Galat, D., Gloss, S., Goodwin, P., Hart, D., Hassett, B., Jenkinson, R., Katz, 
S., Kondolf, G., Lake, P.S., Lave, R., Meyer, J., O’Donnell, T., Pagano, L., Powell, B., \& Sudduth, E. (2005). Synthesizing US river restoration efforts, Science 308, 636-637.

Charlton, M.E., Conveney, S.J., \& McCarthy, T. (2009). Issues in laser scanning. In G.L. Heritage, \& A.R.G. Large (Eds.), Laser Scanning for the Environmental Sciences (pp. 35-48). New Jersey, Wiley-Blackwell Ltd.

Constantz, G., Ailes, N., \& Malakoff, D. (1995). Portrait of a river: the ecological baseline of the Cacapon River. Cacapon Institute. http://www.cacaponinstitute.org. Accessed 2009 March 21.

Evans, B.M., Sheeder, S.A. and Lehning, D.W. (2003), A spatial technique for estimating streambank erosion based on watershed characteristics. Journal of Spatial Hydrology, 3, 1-13.

Gillies, N. (2009). Cacapon Institute. High View, WV. http://www.cacaponinstitute.org/index.htm. Accessed on 21 September 2010.

Goetz, S.J. (2006). Remote sensing of riparian buffers: past progress and future prospects. Journal of the American Water Resources Association, 42, 133-143.

Heuvelink, G.B.M. (1998). Error Propogation in Environmental Modelling with GIS. New York: Taylor and Francis.

Hupp, C.R., Richter, J.M., Peet, R.K., \& Townsend, P.A. (2009). Bank erosion along the dam-regulated lower Roanoke River, North Carolina. Management and Restoration of Fluvial Systems with Broad Historical Changes and Human Impacts: Geological Society of America Special Paper, 451, 97-108.

Kondolf, G.M., \& Micheli, E.R. (1995). Evaluating stream restoration projects. Environmental Management, 19,1-15.

Large, A.R.G. \& Heritage, G. L. (2009). Principles of 3D laser scanning. In G.L. Heritage, \& A.R.G. Large (Eds.), Laser Scanning for the Environmental Sciences (pp. 21-34). New Jersey, WileyBlackwell Ltd. 
Luppi, L., Rinaldi, M., Teruggi, L.B., Darby, S.E., \& Nardi, L. (2008). Monitoring and numerical modeling of riverbank erosion processes: a case study along the Cecina River (central Italy). Earth Surface Processes and Landforms, DOI 10.1002/esp.1754.

O’Neal, M.A., \& Pizzuto, J.E. (2011). The rates and spatial patterns of annual riverbank erosion revealed through terrestrial laser-scanner surveys of the South River, Virginia. Earth Surface Processes and Landforms, 36, 695-701.

Paterson, R.G., Luger, M.I., Burby, R.J., Kaiser, E.J., Malcom, H.R. \& Beard, A.C. (1993). Costs and benefits of urban erosion and sediment control: The North Carolina experience. Environmental Management, 17, 167-178.

Pfankuch, D.J (1975). Stream reach inventory and channel stability evaluation. USDS Forest Service, Region 1, Missoula, Montana.

Resop, J.P., \& Hession, W.C. (2010). Terrestrial laser scanning for monitoring streambank retreat: a comparison with traditional surveying techniques. Journal of Hydraulic Engineering, 136,794 798.

Roni, P., Beechie, T.J., Bilby, R.E., Leonetti, F.E., Pollock, M.M., \& Pess, G.R. (2002). A review of stream restoration techniques and a hierarchical strategy for prioritizing restoration in Pacific Northwest watersheds. North American Journal of Fisheries Management, 22, 1-20.

Rosgen, D. (1996). Applied River Morphology (2nd ed.). Colorado: Wildland Hydrology.

Thoma, D.P., Gupta, S.C., Bauer, M.E., \& Kirchoff, C.E. (2005). Airborne laser scanning for riverbank erosion assessment. Remote Sensing of Environment, 95,493 - 501.

USDA (2011) Soil Survey Geographic Database (SSURGO) for the Eastern Panhandle, WV.

USGS (2011). Great Cacapon, WV. www.waterdata.usgs.gov/usa/nwis/uv?site_no=01611500. Accessed on 23 August 2011.

Van Eps, M.A., S.J. Formica, T.L. Morris, J.M. Beck, and A.S. Cotter (2004), Estimating annual sediment loads from streambank erosion in the West Fork watershed, Arkansas Watershed Advisory Group, North Little Rock, AR. 
Veihe, A., Jensen, N.H., Schiotz, I.G., Nielsen, S.L. (2011) Magnitude and processes of bank erosion at a small stream in Denmark. Hydrological Processes, 25, 1597 - 1613.

Wohl, E., Angermeier, P.L., Bledsoe, B., Kondolf, G.M., MacDonnel, L., Merrit, D.M., Palmer, M.A., Poff, N.L., Tarboton, D. (2005). River restoration. Water Resources Research, 41, 1-12.

Young, A.P, Olsen, M.J., Driscoll, N., Flick, R.E., Gutierrez, R., Guza, R.T., Johnson, E., \& Kuester, F. (2010). Comparison of airborne and terrestrial Lidar estimates of seacliff erosion in southern California. Photogrammetric Engineering \& Remote Sensing, 76, 421-427.

Zaimes, G.N., Schultz, R.C., Isenhart, T.M. (2008) Streambank soil and phosphorus losses under different riparian land-uses in Iowa. Journal of the American Water Resources Association 44, 935 - 947.

Table 1. Estimates of streambank migration derived from repeated erosion pin, streambank profile, and LiDAR surveys along a reach of the Cacapon River, West Virginia. Sites with "lost" represent those sites where erosion pins or toe pins used as benchmarks for repeated profiles were lost between surveys. Positive values represent degradation and negative values represent aggradation.

\begin{tabular}{lllll}
\hline Site & $\begin{array}{l}{ }^{\mathrm{a}} \text { Erosion pins-1 } \\
(\mathrm{m})\end{array}$ & $\begin{array}{l}{ }^{\mathrm{b}} \text { Erosion pins-2 } \\
(\mathrm{m})\end{array}$ & $\begin{array}{l}\text { Streambank profiles } \\
(\mathrm{m})\end{array}$ & $\begin{array}{l}\text { LiDAR } \\
(\mathrm{m})\end{array}$ \\
\hline 1 & 0.69 & 0.80 & lost & -0.09 \\
2 & lost & 0.61 & 1 lost & 1.55 \\
3 & 0.41 & 0.58 & 0.11 & 1.30 \\
4 & 0.50 & 0.68 & 0.32 & 1.49 \\
5 & 0.31 & 0.51 & 0.01 & 4.54 \\
6 & 0.49 & 0.71 & 0.37 & 3.25 \\
7 & 0.29 & 0.50 & lost & 0.40 \\
8 & 0.29 & 0.49 & 0.25 & 6.09 \\
Average (SE) & $0.43(0.06)$ & $0.61(0.04)$ & $0.21(0.07)$ & $2.31(0.75)$ \\
\hline
\end{tabular}

${ }^{\mathrm{a}}$ Average values under Erosion pins-1 were calculated by excluding erosion pins that were lost between surveys.

${ }^{\mathrm{b}}$ Average values under Erosion pins- 2 were calculated by assigning a value of 0.61 to lost erosion pins. 


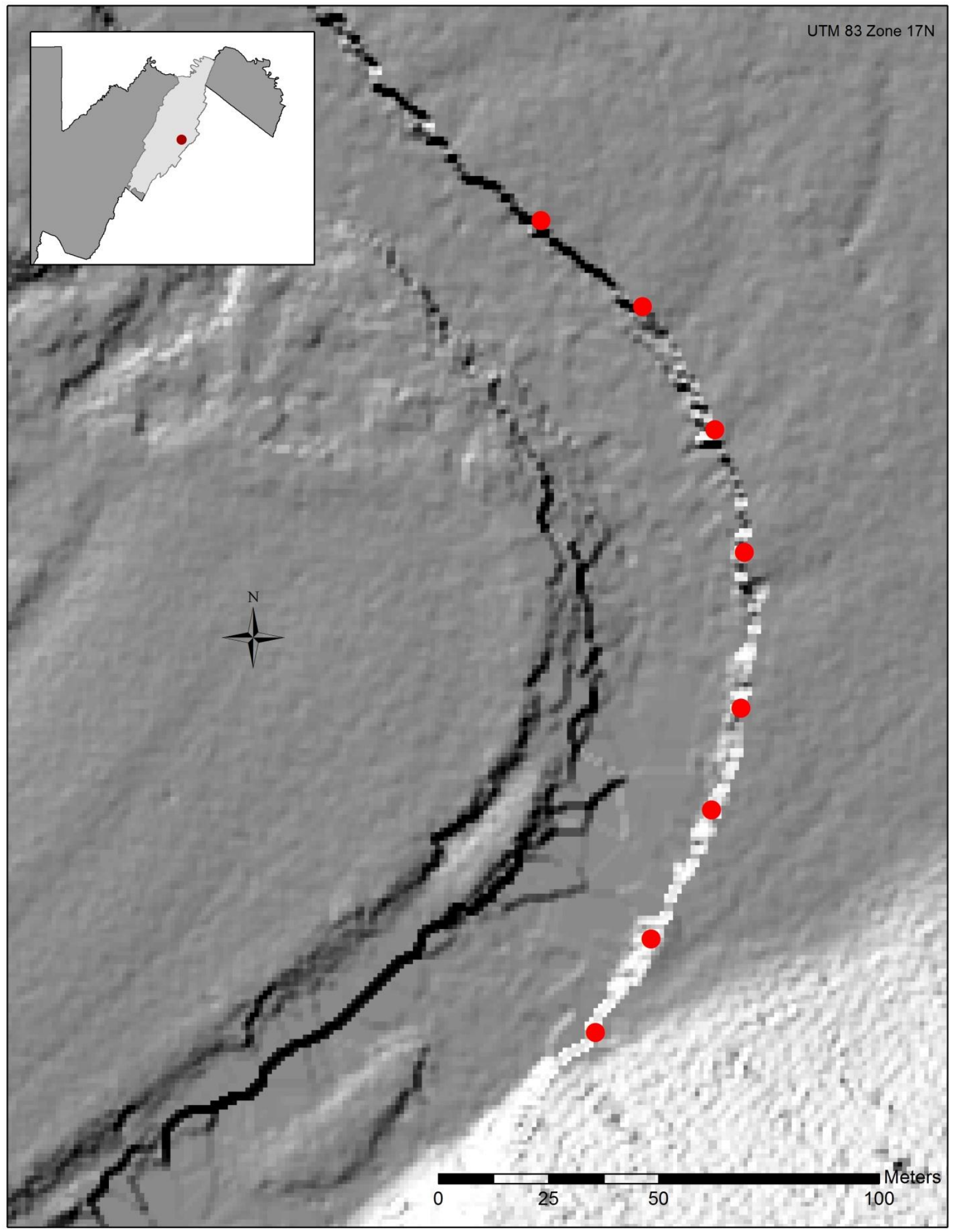

Figure 1. Survey sites at a site along a reach of the Cacapon River in the Cacapon River Watershed in the eastern panhandle of West Virginia, USA used in a comparative study of survey methods for estimating streambank migration and volumetric sediment loss. 

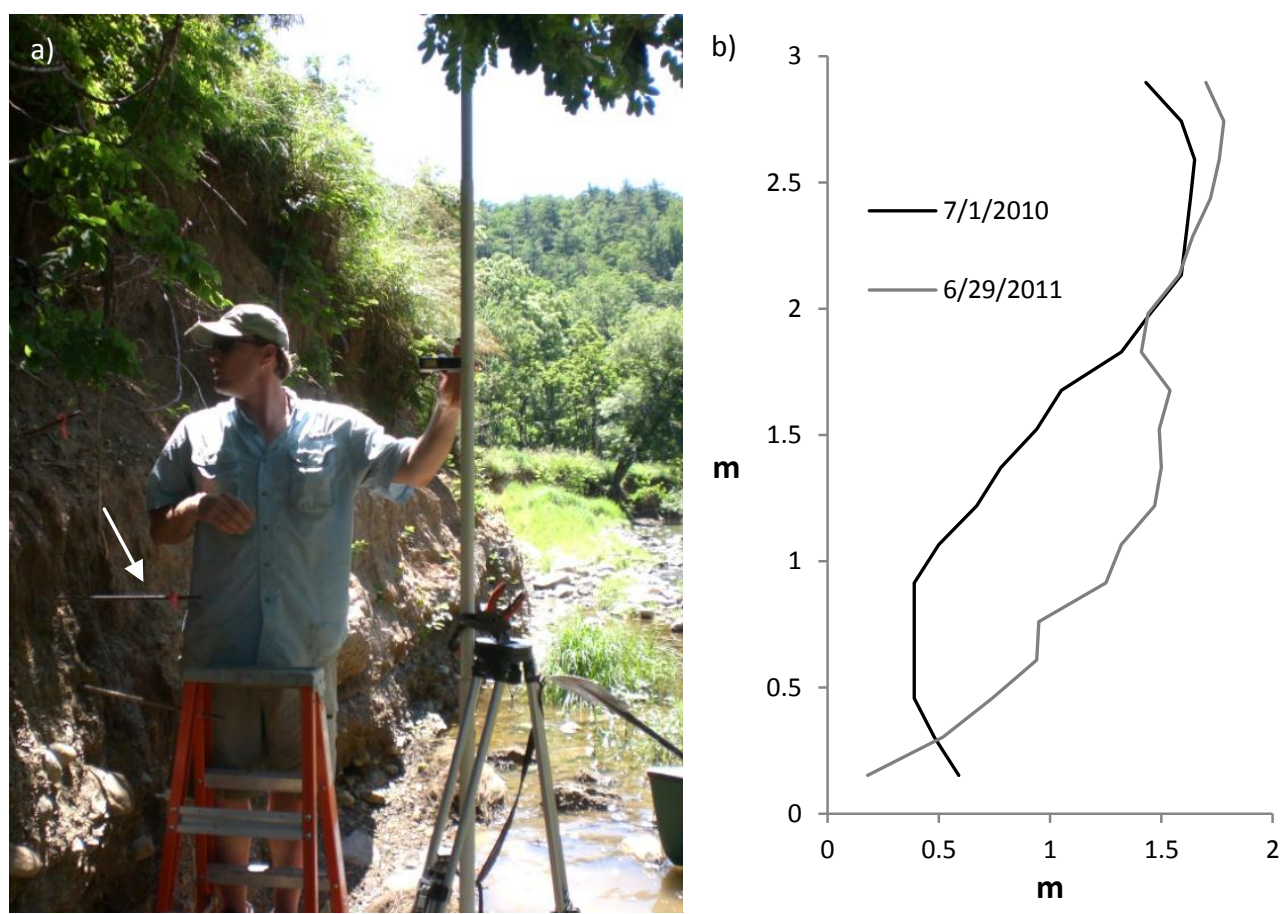

Figure 2. Equipment used to conduct streambank profile surveys along a reach of the Cacapon River, West Virginia, USA showing a) a leveled survey rod anchored to a tripod, where a laser distance measurer was used to collect streambank migration data for creation of b) a streambank profile for 2010 and 2011. The white arrow in the photo is pointing to an erosion pin which was also used to derive an estimate of streambank migration, and for a reference point in the streambank profile survey.
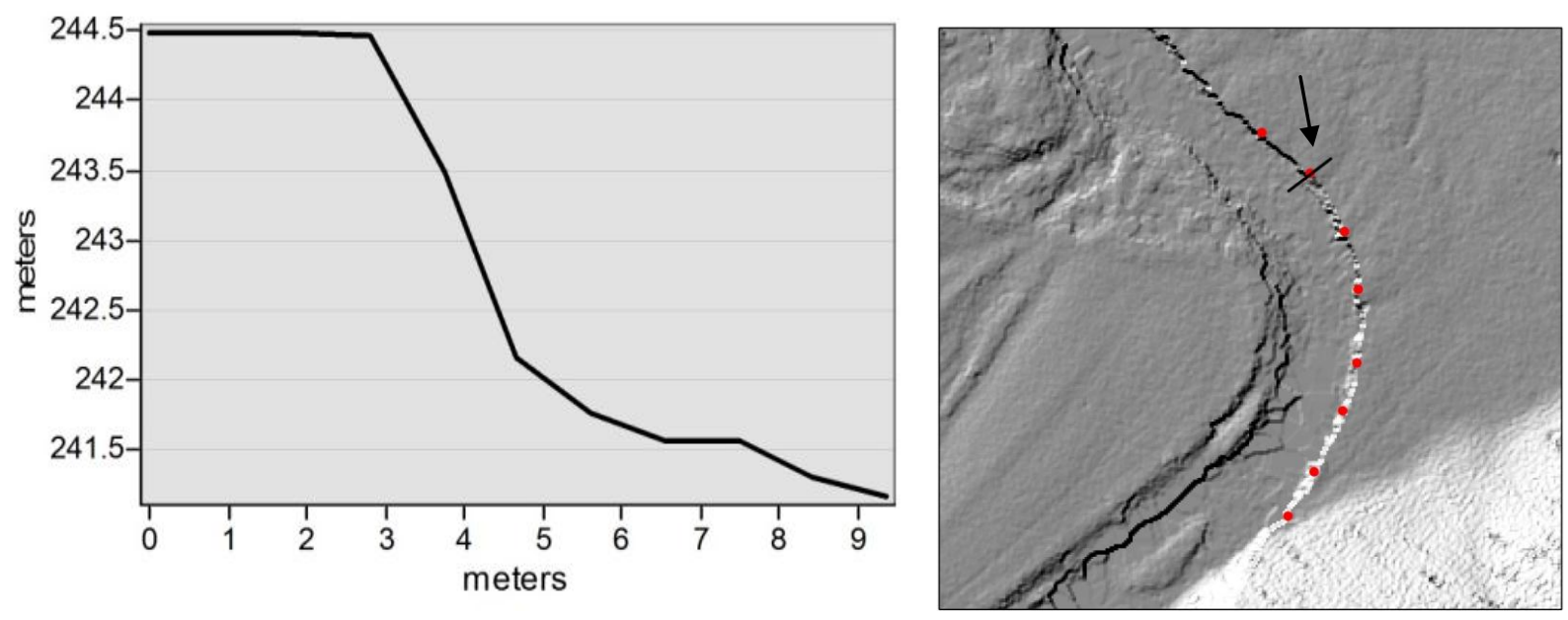

Figure 3. Streambank profile interpolated from airborne LiDAR data collected in 2010 along a reach of the Cacapon River, West Virginia, USA. The profile was generated using 3D Analyst tools in ESRI® $\operatorname{ArcMap}^{\mathrm{TM}} 10.0$ at the location designated by the arrow in the image on the right. 


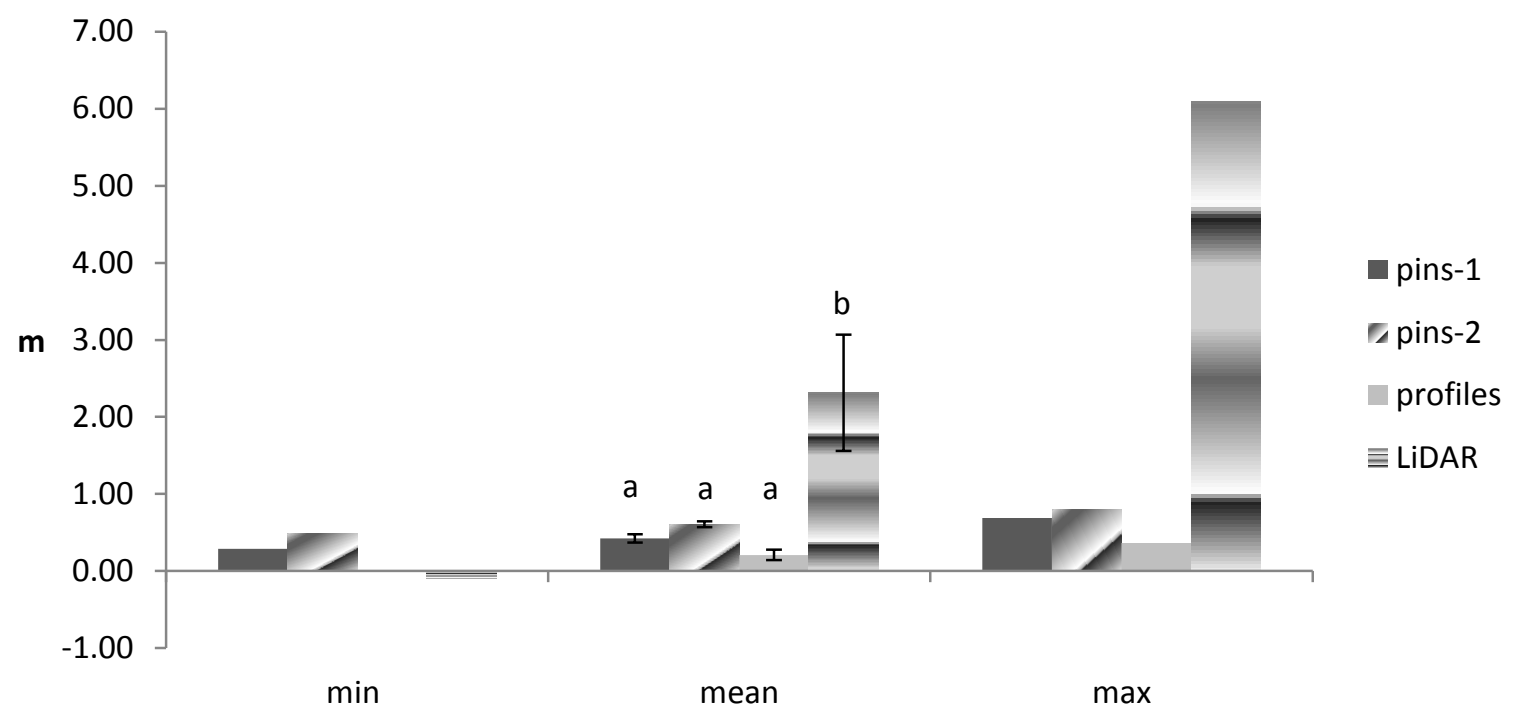

Figure 4. Estimates of streambank migration derived from repeated erosion pin, streambank profile, and LiDAR surveys for a $235 \mathrm{~m}$ reach along the Cacapon River, West Virginia, USA. An Analysis of Variance (ANOVA) on migration showed that estimates derived from erosion pins and streambank profile surveys (a) were different from estimates derived from repeated LiDAR surveys (b). Average values corresponding to "pins-1" were calculated by excluding erosion pins that were lost between surveys. Average values corresponding to "pins-2" were calculated by assigning a value of 0.61 to lost erosion pins.

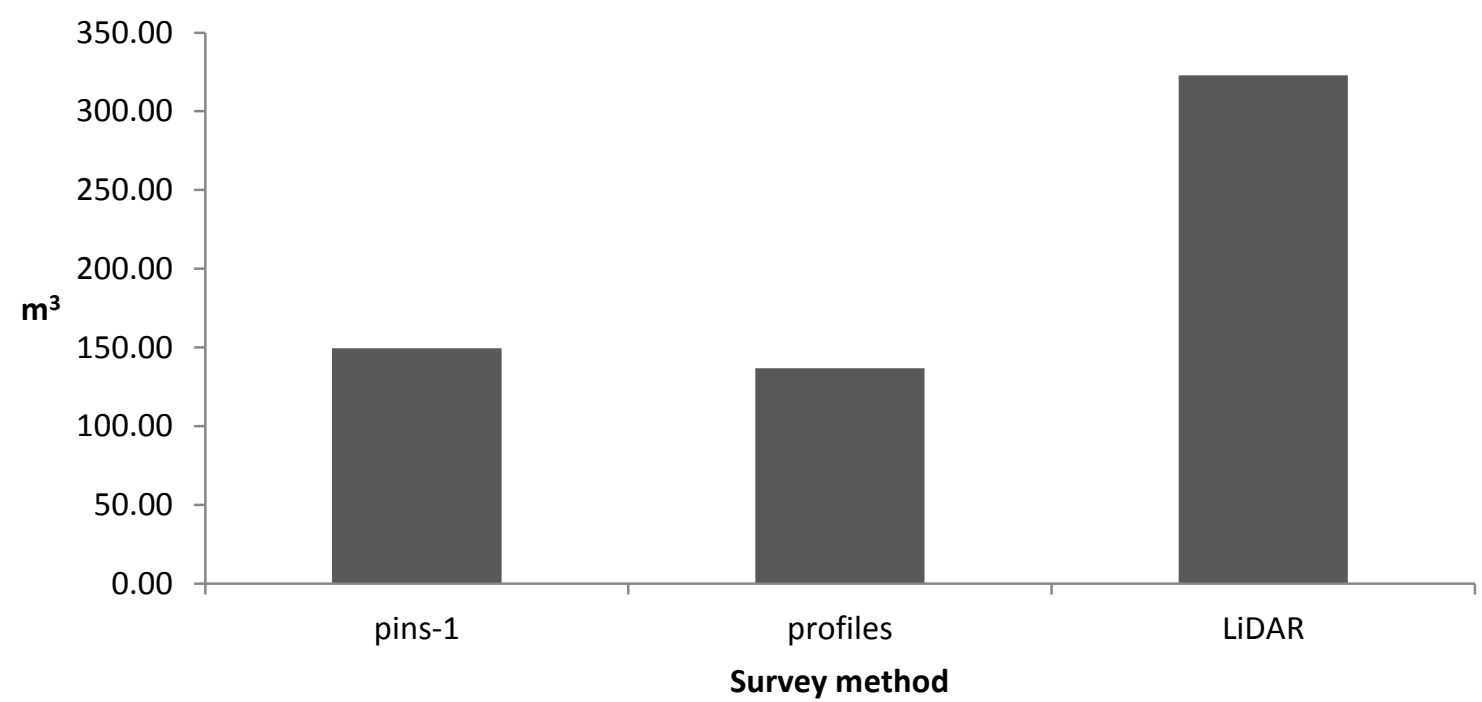

Figure 5. Estimates of volumetric soil loss using repeated erosion pin, streambank profile, and LiDAR surveys for a $235 \mathrm{~m}$ reach along the Cacapon River, West Virginia, USA. Values for "pins-1" were calculated by excluding erosion pins that were lost between surveys 


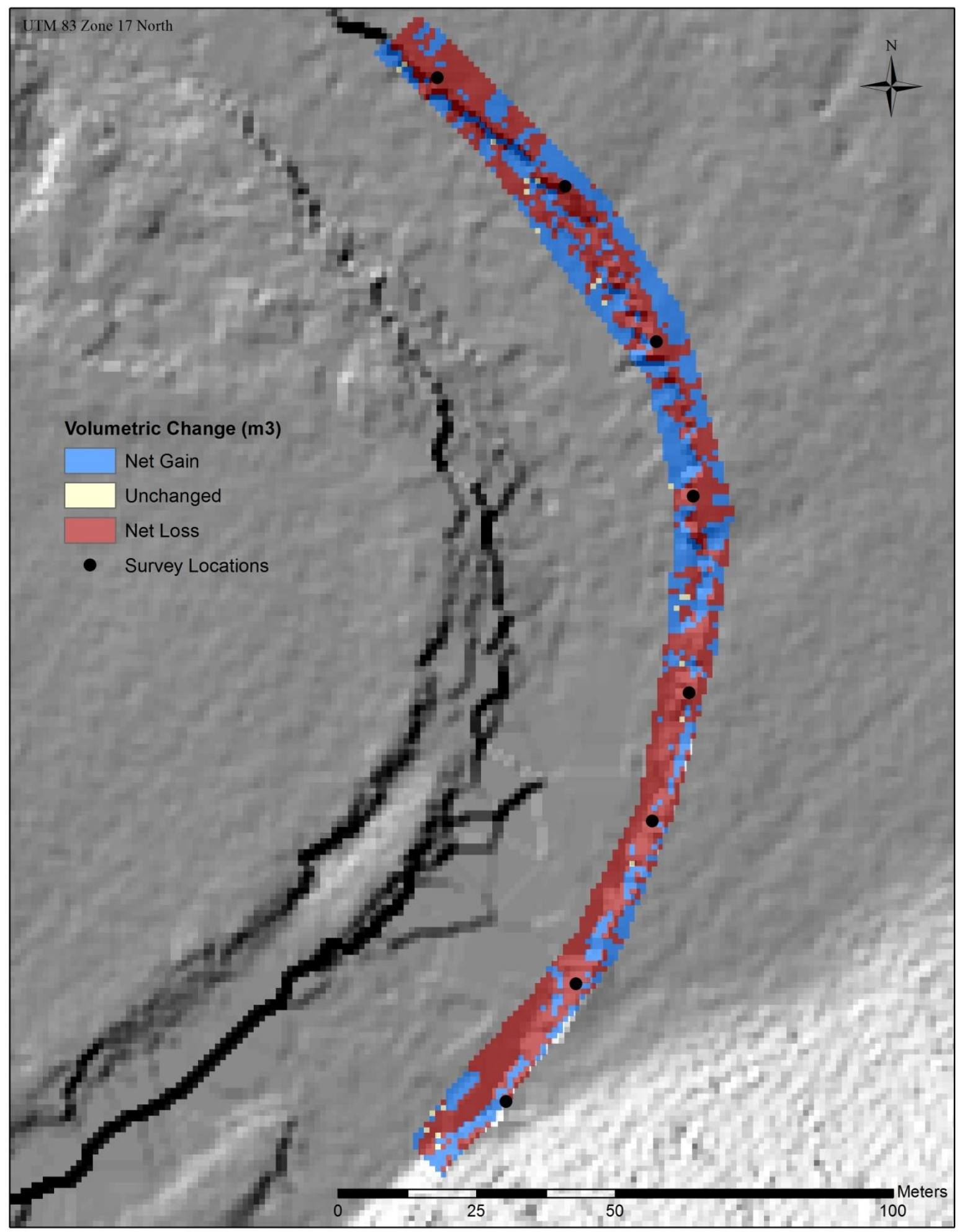

Figure 6. Volumetric change estimated from repeated LiDAR surveys along a $235 \mathrm{~m}$ reach of the Cacapon River, West Virginia, USA. Pixels shaded blue represent areas where a net gain in sediment occurred between surveys, red pixels represent areas where net sediment loss occurred, and yellow pixels represent areas where no change occurred. 
a)

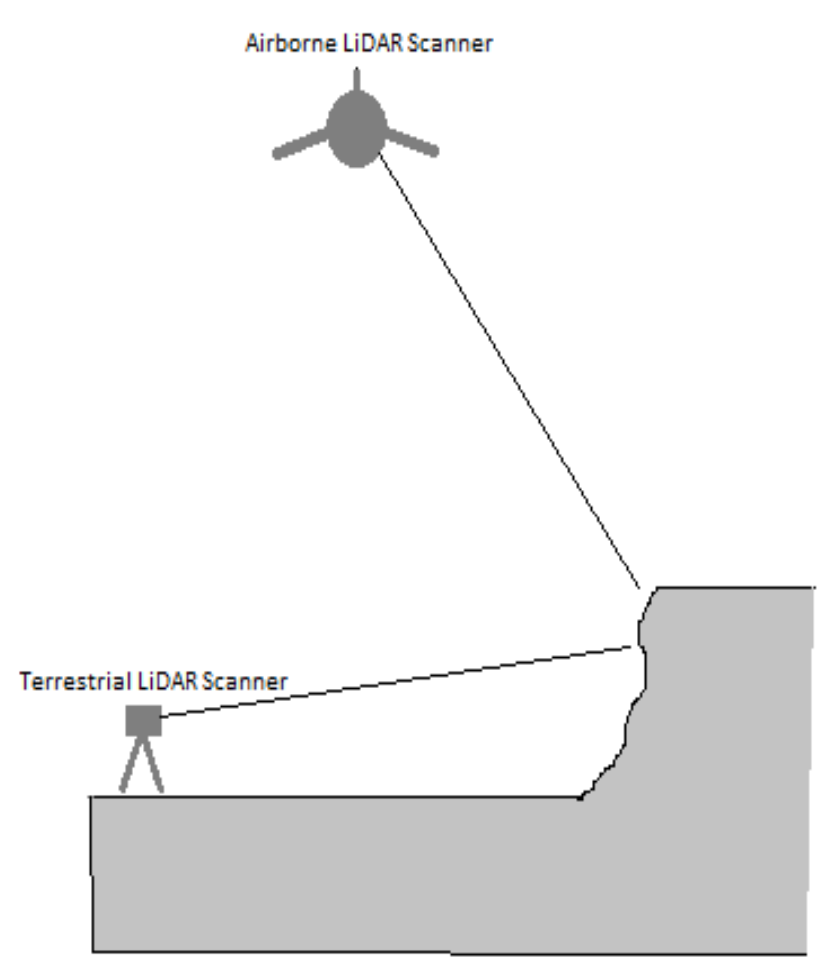

b) 245

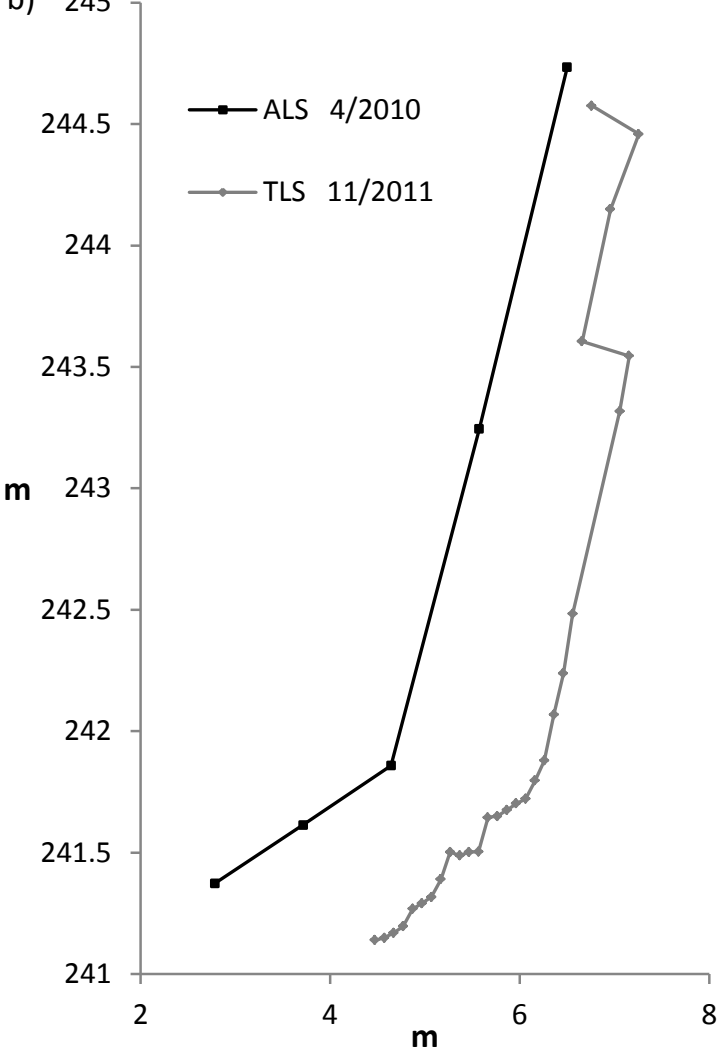

Figure 7. Scan angle of a) airborne LiDAR surveys (ALS) and terrestrial LiDAR surveys (TLS) result in differences in interpolated surfaces as evidenced by streambank profiles derived from b) ALS and TLS along a reach of the Cacapon River, West Virginia, USA. Note the higher point densities for TLS, which was able to more accurately represent undercut portions of the bank face. 


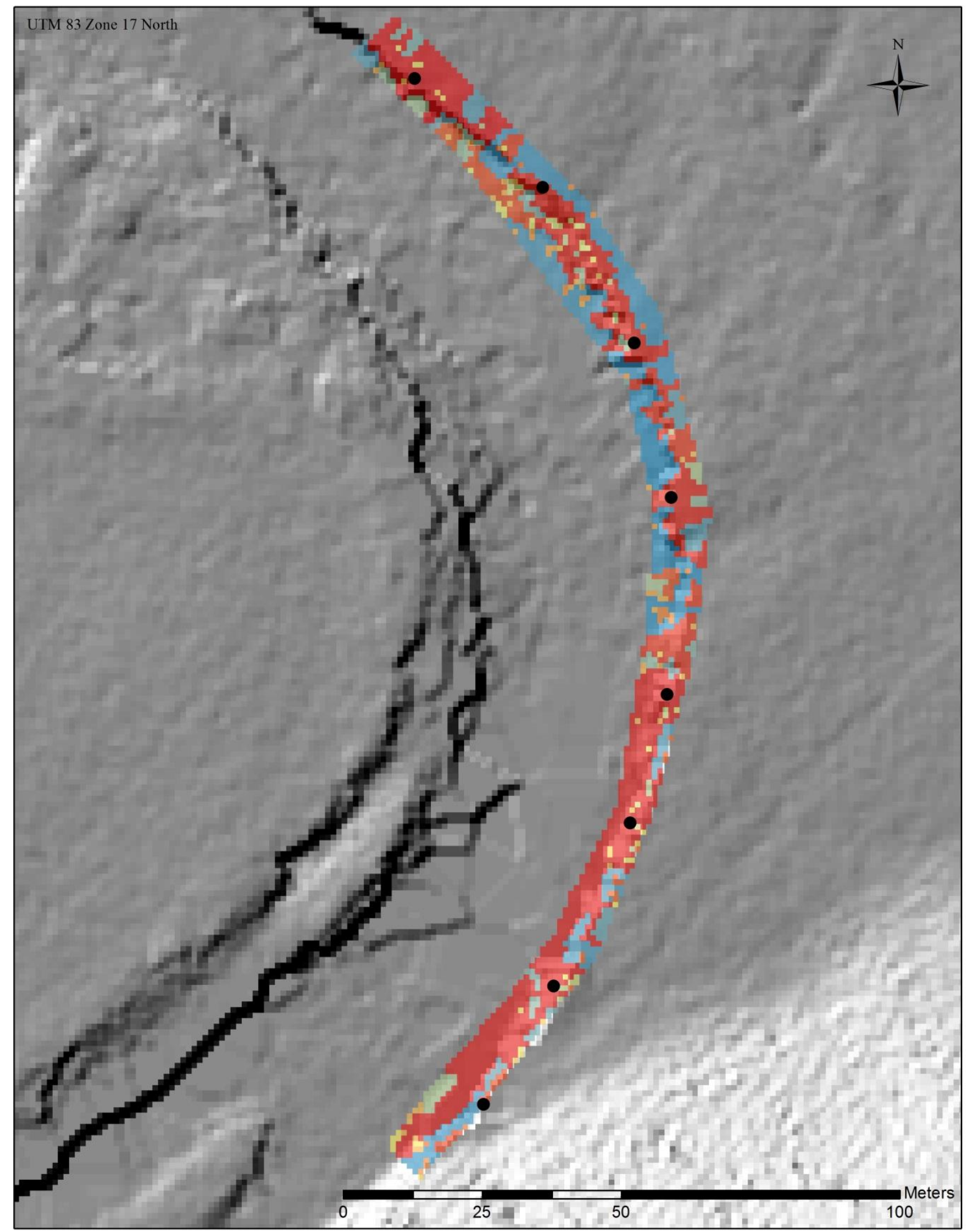

Figure 8. Volumetric change estimated from repeated LiDAR surveys along a $235 \mathrm{~m}$ reach of the Cacapon River, West Virginia, USA symbolized to show variation in sediment loss along the reach. Pixels shaded with cool colors represent areas where sediment gain occurred between surveys, and warm colors represent areas where sediment loss occurred. Neutral colors have values near zero where little change occurred. 


\section{CHAPTER V}

MANAGEMENT IMPLICATIONS FOR STREAM RESTORATION: SITE SELECTION AND PROJECT EVALUATION

Jonathan L. Pitchford

West Virginia University, Division of Forestry and Natural Resources, PO Box 6125, Morgantown, WV 26506-6125 


\section{Introduction}

Stream restoration has become a major component of watershed management strategies aimed at addressing water quality impairment (Roni and others 2002; Lave and others 2010). However, little has been done to objectively evaluate restoration efforts (Kondolf 1996; Bash and Ryan 2002; Bernhardt and others 2005), which has prompted debate regarding the effects of restoration and its role in addressing management concerns (Kondolf 1996; Palmer and others 2003; Wohl and others 2005; Lave and others 2010; Louhi and others 2011; Sudduth and others 2011). Natural channel design (NCD) is a standardized, form based approach for stream restoration that has been endorsed by many federal regulatory agencies (i.e., U.S. Environmental Protection Agency, U.S. Fish and Wildlife Service, Natural Resources Conservation Service, and the U.S. Forest Service) as a valid approach for management of water resources, but has not been fully accepted by many academically trained professionals involved with stream restoration. Debate regarding restoration effectiveness has intensified in light of research documenting several ineffective NCD projects (Kondolf and Micheli 1995; Kondolf 1998; Kondolf and others 2001; Smith and Prestegaard 2005) that has led to concern regarding the widespread application of NCD without formal monitoring in most cases (Kondolf 1996; Bash and Ryan 2002; Bernhardt and others 2005).

A major point of contention among restoration professionals is the idea of "form versus process," where NCD advocates consider a form-based methodology as an adequate solution to address issues such as streambank erosion and riparian enhancement. Many scientists and engineers argue that process measurements (i.e., sediment transport, streambank migration, etc.) are vital to diagnosing and treating degraded systems, and that widespread use of form-based restoration strategies are misguided and have long-term environmental and economic consequences. Government endorsement of NCD has further intensified the debate as "process" advocates, who often lack NCD credentials, have been left out of a growing restoration industry in many cases (Lave and others 2010). Although both camps of the debate have defined mutually exclusive positions on issues such as site selection and design, the practice of stream restoration is relatively new, and a great deal of uncertainty exists in the implementation and 
success of all restoration projects. As such, the purpose of this research was to take a step towards addressing this uncertainty through 1) critically and objective evaluation of a NCD project, 2)

development of a watershed-scale probability model of streambank erosion potential, and 3) evaluation of traditional and modern survey techniques for quantifying streambank stability. This research can be used to provide an objective perspective of NCD effectiveness in a rural setting and as a model for structuring data collection and analysis of restoration effectiveness. The streambank erosion potential model is also a framework that can be replicated in any watershed to provide insight into relative streambank stability, which will inform restoration site selection and design.

\section{Methods}

Study Area

The Cacapon River Watershed is a subwatershed of the Potomac River basin within the larger Chesapeake Bay watershed. The watershed lies within the Appalachian Mountains in the Ridge and Valley physiographic province of West Virginia and includes the North, Lost, and Cacapon Rivers. The watershed drains about 2,320 $\mathrm{km}^{2}$ within Hardy, Hampshire, and Morgan counties (Constantz and others 1995). More than $50 \%$ of the watershed is composed of shale, with sandstone, alluvium, and limestone making up the remaining portion (West Virginia Geological and Economic Survey 2011). The majority of land in the watershed is forested (i.e., 79\%), with some agriculture (i.e., 19\%), and residential development (i.e., 2\%), and has a humid continental climate, characterized by hot summers, cold winters, and average annual precipitation near $90 \mathrm{~cm}$ (Gillies 2009). Monitoring reports indicate that potential water quality stressors are non-point sources of sediment and nitrogen that enter the river via runoff from agricultural and logging operations, which are heaviest in sections of the Lost and Cacapon Rivers (Constantz and others 1995). 


\section{Critical and objective evaluation of a NCD project}

The effects of NCD restoration was monitored along a degraded $750 \mathrm{~m}$ reach of the Cacapon River that was heavily impacted by agriculture, and lacked an intact riparian buffer. The restoration approach consisted of an NCD priority three restoration design that included bankfull bench and log vane construction, and extensive riparian planting (Doll and others 2003). A Before-After-Control-Impact (BACI) experimental design was used to evaluate the success of restoration, which involved repeated sampling of multiple locations within three site types: restoration (i.e., sites within the $750 \mathrm{~m}$ reach receiving a treatment), control (i.e., sites that needed restoration, but did not receive a treatment), and reference (i.e., pristine sites that are not receiving a treatment). We quantified the effects of restoration on parameters associated with, riparian vegetation structure (e.g., abundance, diversity, percent of vegetative cover), streambank stability (e.g., streambank angle, streambank migration), and water quality (e.g., phosphorus, nitrates, total suspended solids, turbidity) using permutational analysis of variance (PERMANOVA). To explore local controls on streambank stability, we also collected detailed vegetation, soils, and stability data from several other locations in the watershed and used correlation and regression tree analysis to determine which factors were most important for predicting streambank instability.

\section{Development of a watershed-scale restoration site selection tool using probability modeling}

A site selection tool was developed using principles of maximum entropy in a geographic information systems (GIS) framework to predict streambank erosion potential (SEP) for a large portion of the Cacapon River Watershed. Specifically, the computer program Maxent, was used to predict the likelihood of presence of target eroding areas (TEAs) within a large portion of the Cacapon River Watershed. The TEAs used as training sites for model development were quantitatively selected from 151 sites throughout the study area where erosion rates were measured from 2010 - 2011 using erosion pin and streambank profile surveys. Predictor variables were raster grids that represented factors associated with TEAs throughout the study extent that were generated from remote sensing data. These 
features included surface topography, shear stress index, soil type, soil moisture, vegetation height, underlying geology, and several other factors previously linked with streambank erosion. Internal validation procedures included area under curve (AUC) analysis where a model with an AUC near one is considered an excellent model, and a one-tailed binomial test of omission to determine if the model was predicting better than random. Thirty model iterations were run using bootstrapping to provide multiple estimates of model performance on testing and training data sets. The likelihood of a TEA was used to create an index of SEP for the study extent, and was tested against erosion rates for the original 151 sites using an analysis of variance (ANOVA).

\section{Evaluation of traditional and modern survey techniques for quantifying streambank stability}

We compared estimates of streambank migration and volumetric soil loss derived from repeated erosion pin, streambank profile, and light detection and ranging (LiDAR) surveys for a $235 \mathrm{~m}$ reach of the Cacapon River to evaluate the benefits and limitations of each method. LiDAR estimates were derived from a combination of airborne and terrestrial LiDAR surveys. Streambank migration was quantified at eight cross sections of the study reach using each method and compared with an ANOVA. Volumetric sediment loss was also quantified at each of the eight cross sections using erosion pin and streambank profile surveys and extrapolated to the reach. Volumetric sediment loss was quantified with LiDAR surveys using tools in ESRI ${ }^{\circledR}$ ArcMap 10.0 ${ }^{\mathrm{TM}}$ 3D Analyst Tools, which provided an estimate over the continuum of the reach. Results of volumetric estimates were compared graphically.

\section{Results}

\section{Critical and objective evaluation of a NCD project}

Overall, an evaluation of an NCD project indicated that restoration had significant effects $(P<$ $0.05)$ on woody vegetation as total abundance increased from $12(\mathrm{SE}=6)$ to $39(\mathrm{SE}=7)$ individuals and Shannon diversity increased from $0.46(\mathrm{SE}=0.18)$ in 2009 (pre-restoration) to $1.47(\mathrm{SE}=0.18)$ in 2011 , one year following restoration. These results were affected by a large number of volunteer black locust 
(Robinia pseudoacacia) and eastern sycamore (Platanus occidentalis) that naturally repopulated excavated streambanks in addition to planted trees and shrubs. Results also indicated that restoration had minimal effects on streambank stability as average streambank migration was $0.13 \mathrm{~m} / \mathrm{yr}(\mathrm{SE}=0.04)$ before restoration compared to $0.05 \mathrm{~m} / \mathrm{yr}(\mathrm{SE}=0.06)$ following restoration. Different responses were detected within the restored reach as bank retreat stopped or slowed at three monitored sub-reaches (e.g., $0.21 \mathrm{~m} / \mathrm{yr}(\mathrm{SE}=0.12)$ before restoration to $0.02 \mathrm{~m} / \mathrm{yr}(\mathrm{SE}=0.04)$ one year post-restoration $)$, but increased at one sub-reach from $0.05 \mathrm{~m} / \mathrm{yr}(\mathrm{SE}=0.02)$ before restoration to $0.33 \mathrm{~m} / \mathrm{yr}(\mathrm{SE}=0.19)$ one year after restoration (Figure 1). Repeated streambank profiles indicated similar variation in responses among sub-reaches, but showed that overall $39 \mathrm{~m}^{3}$ of sediment was lost from the reach before restoration compared to net storage of $66.6 \mathrm{~m}^{3}$ in the year following project completion indicating that restoration did reduce total sediment and nutrients from entering the river via streambank erosion.

Only slight changes were detected among monitored water quality variables following restoration with the exception of turbidity which increased from 8 nephelometric turbidity units (NTU) (SE $=3.6$ ) prior to restoration to $168 \mathrm{NTU}(\mathrm{SE}=13.6)$ during construction. Increased turbidity resulted in reductions of the percentage of Ephemeropteran, Plecopteran, and Trichopteran taxa (\% EPT) in aquatic macroinvertebrate samples from $48 \%$ before restoration to $12 \%$ during construction (Selego 2011). One year following completion of restoration turbidity was near pre-restoration levels at 30 NTU (SE = 10.3), and $\%$ EPT increased to $38 \%$.

Correlation and regression tree analysis indicated that the percentage of bare ground was the most important predictor associated with streambank erosion, and that differences in streambank response to bankfull bench construction were likely the result of vegetation removal on streambanks composed of sandy soils. For example, a sub-reach that experienced the largest decreases in streambank migration (i.e., increased rate of soil loss), and subsequent losses of the majority of riparian plantings was composed of $86 \%(\mathrm{SE}=2.6)$ sand. This area was relatively stable before construction and was heavily vegetated; however, restoration resulted in increases in erosion in this area because of vegetation removal and exposure of an underlying substrate composed predominantly of sand. 


\section{Development of a watershed-scale restoration site selection tool using probability modeling}

We identified a total of 29 TEAs from 151 sites where erosion rates were monitored. Twentythree TEAs were detected based on migration rates ranging from $0.53-0.93 \mathrm{~m} / \mathrm{yr}$ using erosion pin surveys, and six were detected based on net sediment loss ranging from $1.2-2.29 \mathrm{~m}^{2} / \mathrm{yr}$ using streambank profile surveys (Figure 2). Only two sites were detected as TEAs using data from both survey methods. We successfully constructed a likelihood distribution of TEAs from occurrence records and nine associated environmental variables over our study extent. The model indicated that the four most important environmental variables controlling these processes were streambank slope, soil type, shear stress index, and underlying geology. All model validation procedures indicated that the model was an excellent predictor of TEAs as the average training AUC value was 0.994 (SE $=0.0004)$, and average test AUC for all model runs was $0.985(\mathrm{SE}=0.002)$ indicating excellent model performance. The binomial omission test was also significant for all data partitions indicating that the model predicted much better than random $(P<0.01)$. A classification scheme with low, moderate, and high levels of erosion potential derived from logistic model output was able to differentiate sites with low SEP from sites with moderate and high SEP, but could not differentiate between sites with moderate and high SEP.

\section{Evaluation of traditional and modern survey techniques for quantifying streambank stability}

Results showed that average estimated streambank migration of $0.43 \mathrm{~m}(\mathrm{SE}=0.06)$ derived from erosion pins and $0.21 \mathrm{~m}(\mathrm{SE}=0.07)$ derived from streambank profile surveys were similar, but that LiDAR derived estimates were significantly greater at $2.31 \mathrm{~m}(\mathrm{SE}=0.75)(P<0.05)$. Similar findings were associated with volumetric soil loss, which was estimated at $149.39 \mathrm{~m}^{3}$ and $136.63 \mathrm{~m}^{3}$, for erosion pins and profiles, respectively, but was again higher for LiDAR derived estimates at $323.2 \mathrm{~m}^{3}$.

\section{Conclusions}

The most important local factors that determined success or failure of streambank stabilization treatments in our study appeared to be related to pre-treatment stability, vegetative cover, and soil 
composition that could only be accounted for using pre-restoration data collection and process measurements. The "form versus process" debate among stream restorationists and scientists often deem NCD and process-based restoration as mutually exclusive (Kondolf and others 2001; Simon and others 2007; Simon and others 2008; Rosgen 2008; Lave and others 2010); however, the results of our study indicated that process measurements prior to restoration design could facilitate better use of valuable NCD techniques. For example, the bankfull bench technique used in our study clearly has merit for streambank stabilization and riparian enhancement (Doll and others 2003); however, site selection for this approach is extremely important as demonstrated by increased instability resulting from bankfull bench construction in some areas. Examining local variability in restoration potential through process measurements or models is a vital component of successful restoration using any approach (Doyle and others 1999; Wohl and others 2005). Limited resources often prevent extensive pre-project data collection in many cases (Bash and Ryan 2002); however, management strategies developed using data from potential restoration sites will undoubtedly increase management success rates regardless of the techniques used.

High resolution process models provide a way to understand streambank processes over a large extent, thus improving watershed management strategies. The maximum entropy model of SEP is a good example of a process model that could enhance watershed planning by providing a quantitative framework for prioritizing sites for management, and for determining which environmental variables control streambank erosion. This type of modeling framework has been suggested by restoration scientists as an important component for improved management of water resources (Wohl and others 2005), and we believe that Bayesian approaches like maximum entropy can be used for further development of watershed assessment tools due to their robust approach for modeling spatial distributions of environmental phenomena (Phillips and others 2006; Dudik and others 2007; Pearson 2007; Beane 2010) and processes (Dahal and others 2008; Moghaddam and others 2007; Regmi and others 2010). Such models could help to bridge the gap between restoration science and practice by helping practitioners determine which areas to target with management activities, and what conditions to recreate 
based on conditions at sites where the model predicts SEP is low. By doing so, our model helps to identify sites with the greatest restoration potential, which is a critical component of effective stream restoration (Wohl and others 2005).

Remote sensing has a valuable role to play in improving watershed management including aiding in process measurements (Resop and Hession 2010; Young and others 2010, O’Neal and Pizzuto 2011). However, our results suggest that combining airborne and terrestrial LiDAR data sets is not the best way to quantify topographic change in streambanks. Problems associated with beam grazing and low point densities associated with airborne LiDAR data can result in interpolation error and inflated LiDAR derived estimates. Erosion pin and streambank profile surveys, while labor intensive, actually provide a low cost means for obtaining accurate estimates of sediment loss from streambanks. The biggest problem associated with traditional methods in our study was due to extrapolation error and pin loss, which limits the usefulness of this approach along highly dynamic stream reaches. Although cost-prohibitive in some cases, repeated terrestrial LiDAR scans with favorable scan angles and higher point densities would likely provide the most accurate estimate of channel change as this method allows for high resolution estimates over a streambank continuum with minimal time investment in the field (Resop and Hession 2010; O’Neal and Pizzuto 2011) (Figure 3).

More work needs to be done to address uncertainty in stream restoration as objective evaluation of restoration is quite rare relative to the large number of projects being conducted in many areas of the world. However, this research should help to inform restoration planning and evaluation, which will ultimately improve water resource management. Also, this work should help to bridge the gap between restoration science and practitioners by showing that form- and process-based solutions for stream restoration are not mutually exclusive. The ability to collect process measurements and generate process models is becoming easier with new technological and analytical tools that can help determine where form based solutions will have the greatest chances for success. 


\section{Future Research Needs}

The findings of this research have identified several research avenues that warrant further study. These include:

- Quantifying the effects of bankfull bench construction in different soil types with a wide range of particle sizes to determine those substrate types where natural channel design (NCD) priority three restoration will have the greatest chances of success.

- Examining the effects of log vanes on bankfull bench success to determine where placement of log vanes will optimize streambank stability.

- Quantifying recruitment rates of trees and herbaceous vegetation on reconstructed streambanks and comparing results to control sites where no work is being done to enhance streambank stability.

- Comparing success rates of different species of planted riparian vegetation to determine which species are most suited for stream restoration applications.

- Comparing the effects of reach-scale restoration $(10-1,000 \mathrm{~m})$ with segment- $(100-10,000 \mathrm{~m})$ and watershed-scale $(50-500 \mathrm{~km})$ restoration on various water quality parameters.

- Experimentation to determine if continuous turbidity monitoring can be used to estimate rates of streambank erosion.

- Experimentation to test the application of the maximum entropy model of streambank erosion potential (SEP) for restoration site selection compared to site selection informed by indices such as bank erosion hazard index (BEHI) used in NCD.

- Development of maximum entropy models of SEP in other watersheds with different stressors and controlling factors related to streambank stability (i.e., urban watersheds) and testing of model predictions on erosion rates. 
- Comparing streambank erosion estimates derived from repeated erosion pin and streambank profile surveys with repeated terrestrial LiDAR estimates, and estimates derived from repeated airborne LiDAR.

\section{References}

Bash JS, Ryan CM (2002) Stream restoration and enhancement projects: is anyone monitoring? Environmental Management 29:877-885

Beane NR (2010) Using Environmental and site-specific variables to model current and future distribution of red spruce (Picea rubens Sarg.) forest habitat in West Virginia, Ph.D. Dissertation. West Virginia University, Morgantown.

Bernhardt E, Palmer M, Allan J, Alexander G, Barnas K, Brooks S, Carr J, Clayton S, Dahm C, FollstadShah J, Galat D, Gloss S, Goodwin P, Hart D, Hassett B, Jenkinson R, Katz S, Kondolf G, Lake PS, Lave R, Meyer J, O’Donnell T, Pagano L, Powell B, Sudduth E (2005) Synthesizing US river restoration efforts. Science 308:636-637

Constantz G, Ailes N, Malakoff D (1995) Portrait of a river: the ecological baseline of the Cacapon River. Cacapon Institute. http://www.cacaponinstitute.org. Accessed 2009 March 21

Dahal RK, Hasegawa S, Nonomura A, Yamanaka M, Masuda T, and Nishino K (2008) GIS-based weights-of-evidence modelling of rainfall-induced landslides in small catchments for landslide susceptibility mapping. Environmental Geology 54:311-324

Doll BA, Grabow GL, Hall KR, Halley J, Harman WA, Jennings GD, Wise DE (2003) Stream Restoration: A Natural Channel Design Handbook. Prepared by the North Carolina Stream Restoration Institute and the North Carolina Sea Grant.

Doyle MW, Miller DE, Harbor JM (1999) Should river restoration be based on classification schemes or process models? Insights from the history of geomorphology. Proceedings of the International Conference on Water Resources Engineering, Seattle, Washington. 
http://www.globalrestorationnetwork.org/uploads/files/LiteratureAttachments/466_should-riverrestoration-be-based-on-classification-schemes-or-process-models.pdf. Accessed 16 July 2010

Dudik M, Phillips SJ, and Schapire RE (2007) Maximum entropy density estimation with generalized regularization and an application to species distribution modeling. Journal of Machine Learning Research 8:1217-1260

Gillies N (2009) Cacapon Institute. High View, WV. http://www.cacaponinstitute.org/index.htm. Accessed on 21 September 2010

Kondolf GM, Micheli ER (1995) Evaluating stream restoration projects. Environmental Management 19:1-15

Kondolf GM (1996) A cross section of stream channel restoration. Journal of Soil and Water Conservation 51:119-125

Kondolf GM (1998) Lessons learned from river restoration projects in California. Aquatic Conservation: Marine and Freshwater Resources 8:39-52

Kondolf GM, Smeltzer MW, Railsback SF (2001) Design and performance of a channel reconstruction project in a coastal California gravel-bed stream. Environmental Management 28:761-776

Lave R, Doyle M, Robertson M (2010) Privatizing stream restoration in the US. Social Studies of Science 40:677-703

Louhi, P H, Mykra R, Paavola A, Huusko T, Vehanen, Ma ki-Peta A, Muotka T (2011) Twenty years of stream restoration in Finland: little response by benthic macroinvertebrate communities. Ecological Applications 21:1950-1961

Moghaddam MGR, Khyyam M, Ahmadi, M and Farajzadeh M (2007) Mapping susceptibility landslide using the weight-of-evidence model: a case study in Merek Valley, Iran. Journal of Applied Sciences 7:3342-3355

O’Neal MA, and Pizzuto JE (2011) The rates and spatial patterns of annual riverbank erosion revealed through terrestrial laser-scanner surveys of the South River, Virginia. Earth Surface Processes and Landforms 36:695-701 
Palmer MA, Hart DD, Allan JD, Bernhardt E (2003) Bridging engineering, ecological, and geomorphic science to enhance river restoration: local and national efforts. Proceedings of a National Symposium of Urban and Rural Stream Protection and Restoration, EWRI World Water and Environmental Congress. American Society for Civil Engineers, Reston, Va. http://www.palmerlab.umd.edu/docs/Palmer_et_al_World_Water_Congress_final_Feb_03.pdf. Accessed 8 March 2010

Pearson RG (2007) Species' distribution modeling for conservation educators and practitioners, Synthesis, American Museum of Natural History, New York

Phillips SJ, Anderson RP, and Schapire RE (2006) Maximum entropy modeling of species geographic distributions. Ecological Modelling 190:231-259

Regmi NR, Giadino JR, and Vitek JD (2010) Modeling susceptibility to landslides using the weight of evidence approach: western Colorado, USA. Geomorphology 115:172-187

Resop JP, and Hession WC (2010) Terrestrial laser scanning for monitoring streambank retreat: a comparison with traditional surveying techniques. Journal of Hydraulic Engineering 136:794 798

Roni P, Beechie TJ, Bilby RE, Leonetti FE, Pollock MM, Pess GR (2002) A review of stream restoration techniques and a hierarchical strategy for prioritizing restoration in pacific northwest watersheds. North American Journal of Fisheries Management 22:1-20

Rosgen, D (2008) Reply to discussion "Critical Evaluation of how the Rosgen classification and associated 'Natural Channel Design' methods fail to integrate and quantify fluvial process and channel responses" by A Simon, M. Doyle, M. Kondolf, F.D. Shields Jr., B. Rhoads, and M. McPhillips. Journal of the American Water Resources Association 44:782-789

Selego SM (2011) Fish and aquatic macroinvertebrate communities in the Cacapon River, West Virginia. Thesis, West Virginia University

Simon A, Doyle M, Kondolf M, Shields FD, Rhoads B, McPhillips M (2007) Critical evaluation of how the Rosgen classification and associated 'Natural Channel Design' methods fail to integrate and 
quantify fluvial processes and channel response. Journal of the American Water Resources Association 43:1117-1131

Simon A, Doyle M, Kondolf M, Shields FD, Rhoads B, McPhillips M (2008) Reply to discussion by Dave Rosgen "Critical evaluation of how the Rosgen classification and associated 'Natural Channel Design' methods fail to integrate and quantify fluvial processes and channel responses". Journal of The American Water Resources Association 44:782-792

Smith SM, Prestegaard KL (2005) Hydraulic performance of a morphology-based stream channel design. Water Resources Research 41:1-17

Sudduth EB, Hassett BA, Cada P, and Bernhardt ES (2011) Testing the field of dreams hypothesis: functional responses to urbanization and restoration in stream ecosystems. Ecological Applications 21:1972-1988

West Virginia Geological and Economic Survey (2011) Mont Chateau Research Center. http://www.wvgs.wvnet.edu/. Accessed 8 March 2011

Wohl E, Angermeier PL, Bledsoe B, Kondolf GM, MacDonnel L, Merrit DM, Palmer MA, Poff NL, Tarboton D (2005) River restoration. Water Resources Research 41:1-12

Young AP, Olsen MJ, Driscoll N, Flick RE, Gutierrez R, Guza RT, Johnson E, and Kuester F (2010) Comparison of Airborne and Terrestrial Lidar estimates of seacliff erosion in southern California. Photogrammetric Engineering \& Remote Sensing 76:421-427 

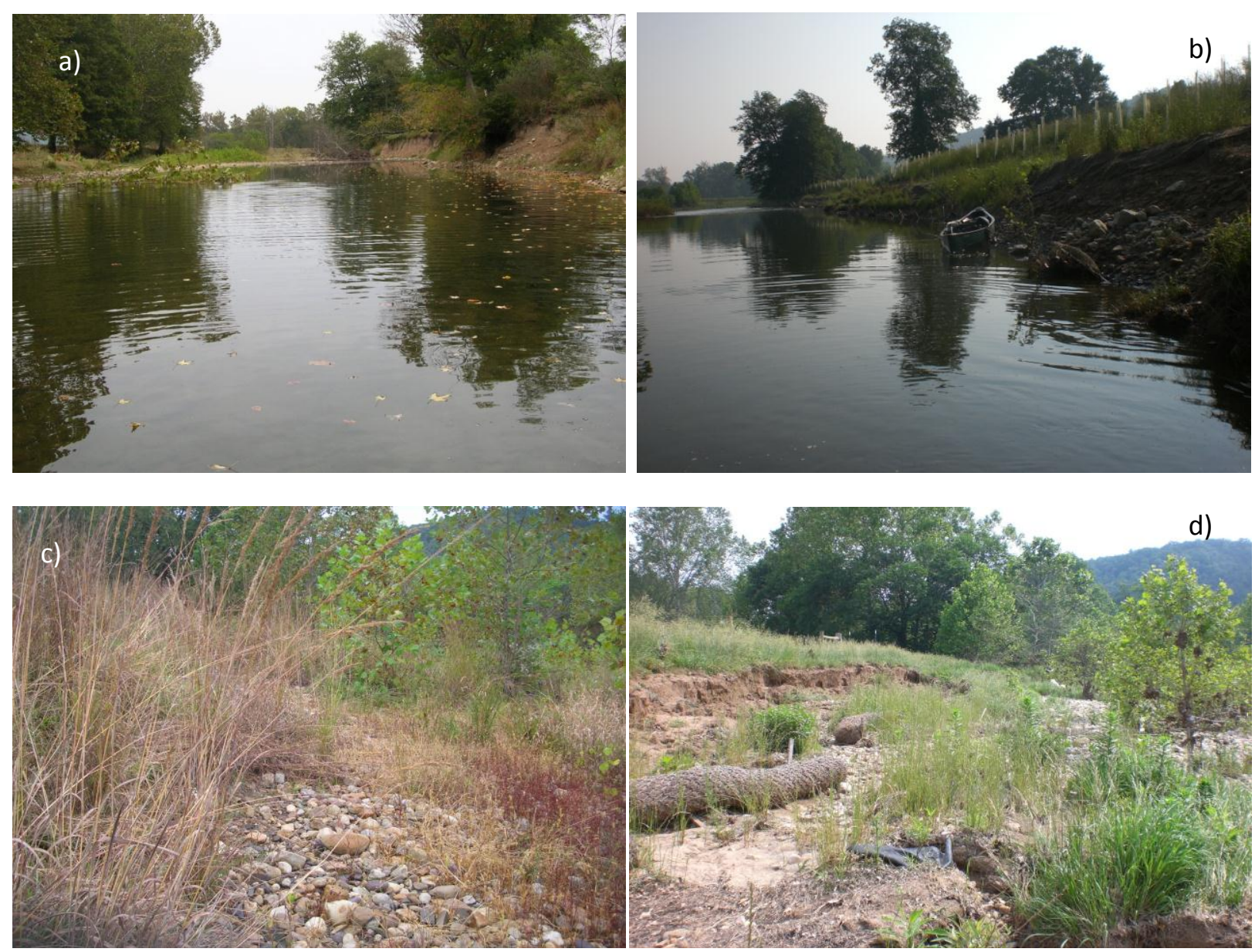

Fig. 1 Photos showing different responses to stream restoration within a restored reach of the Cacapon River, West Virginia from 2009 (left) - 2011 (right). Restoration was considered successful at one subreach as streambank stability increased (i.e., soil loss decreased) from a) 2009 to b) 2011; however, efforts were considered unsuccessful at another sub-reach where soil loss increased from c) 2009 to d) 2011. 

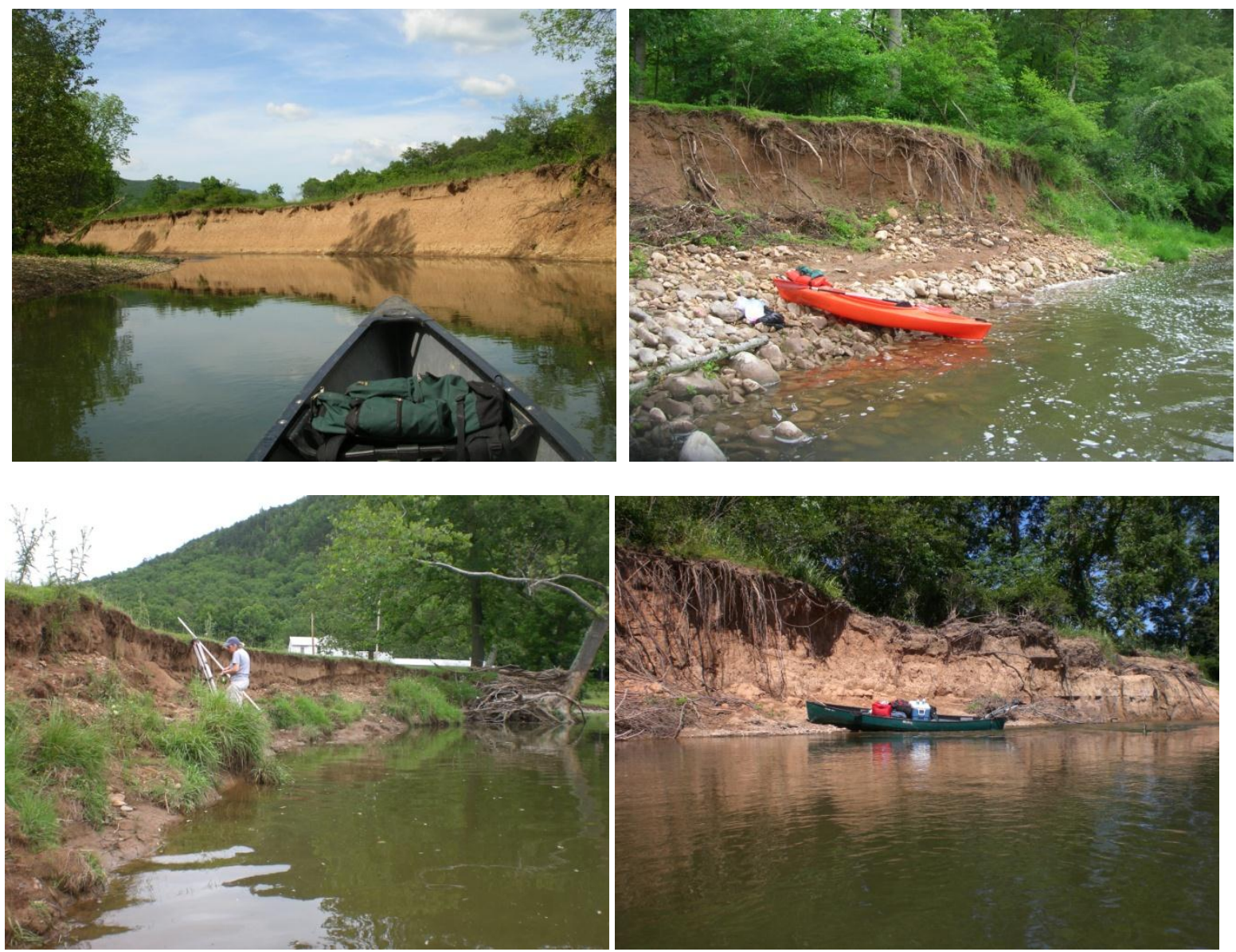

Fig. 2 Photos from four reaches in the Cacapon River Watershed, West Virginia where target eroding areas (TEAs) were detected based on erosion rates measured from $2010-2011$. TEAs were used as training sites to develop a model of streambank erosion potential (SEP) over the study extent. 


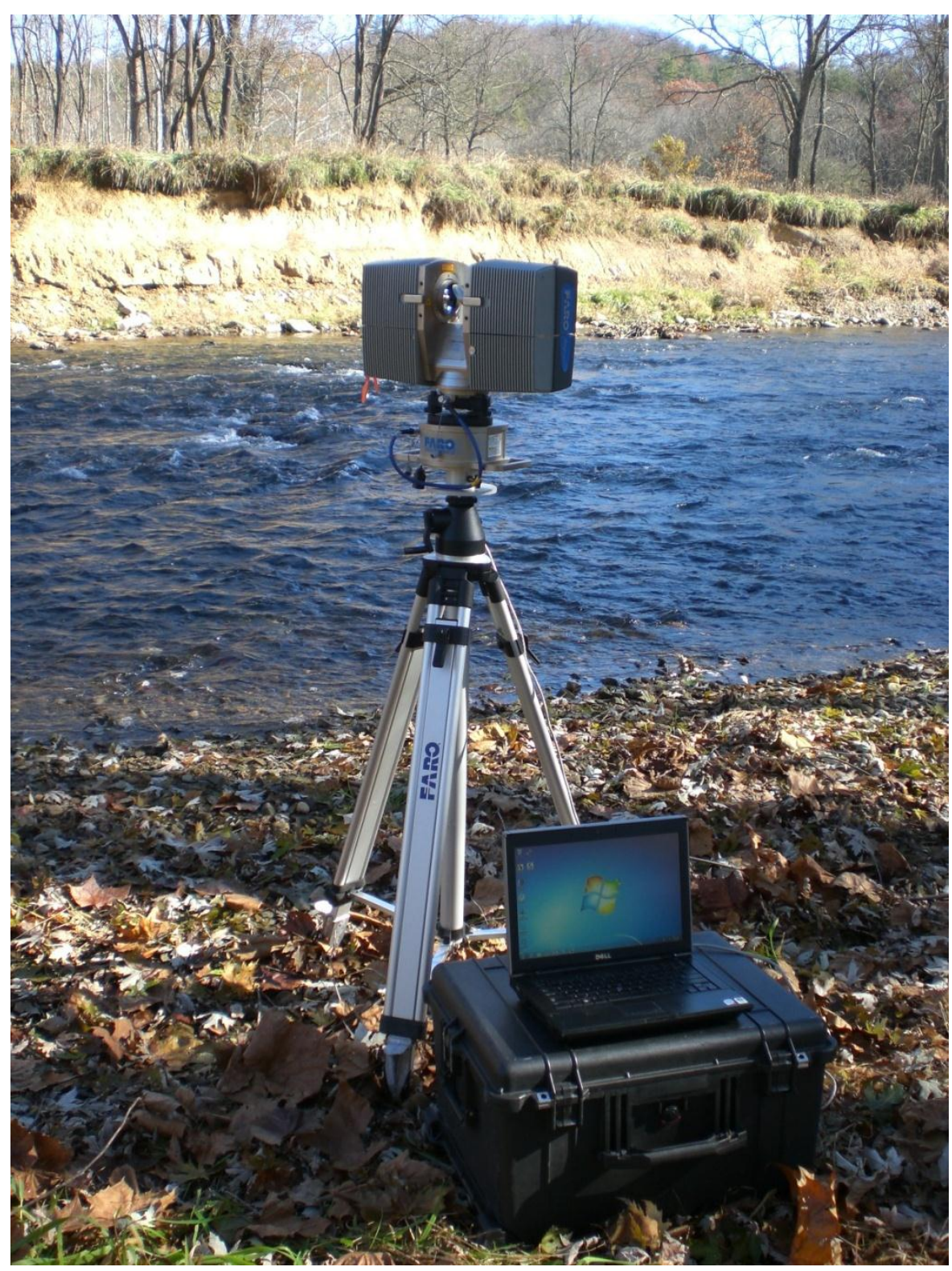

Fig. 3 Photo showing a terrestrial LiDAR scanner used to create a three dimensional model of the streambank across the river. Scanner position allowed for better scan angles for capturing features such as undercut banks compared to airborne LiDAR scans, and high point densities of terrestrial scans can be used to produce accurate, high resolution data sets from which streambank migration and volumetric sediment loss can be estimated. 
Appendix Ia. Bank erosion hazard index (BEHI) used to select sites used to evaluate the effects of stream restoration in the Cacapon River, West Virginia.
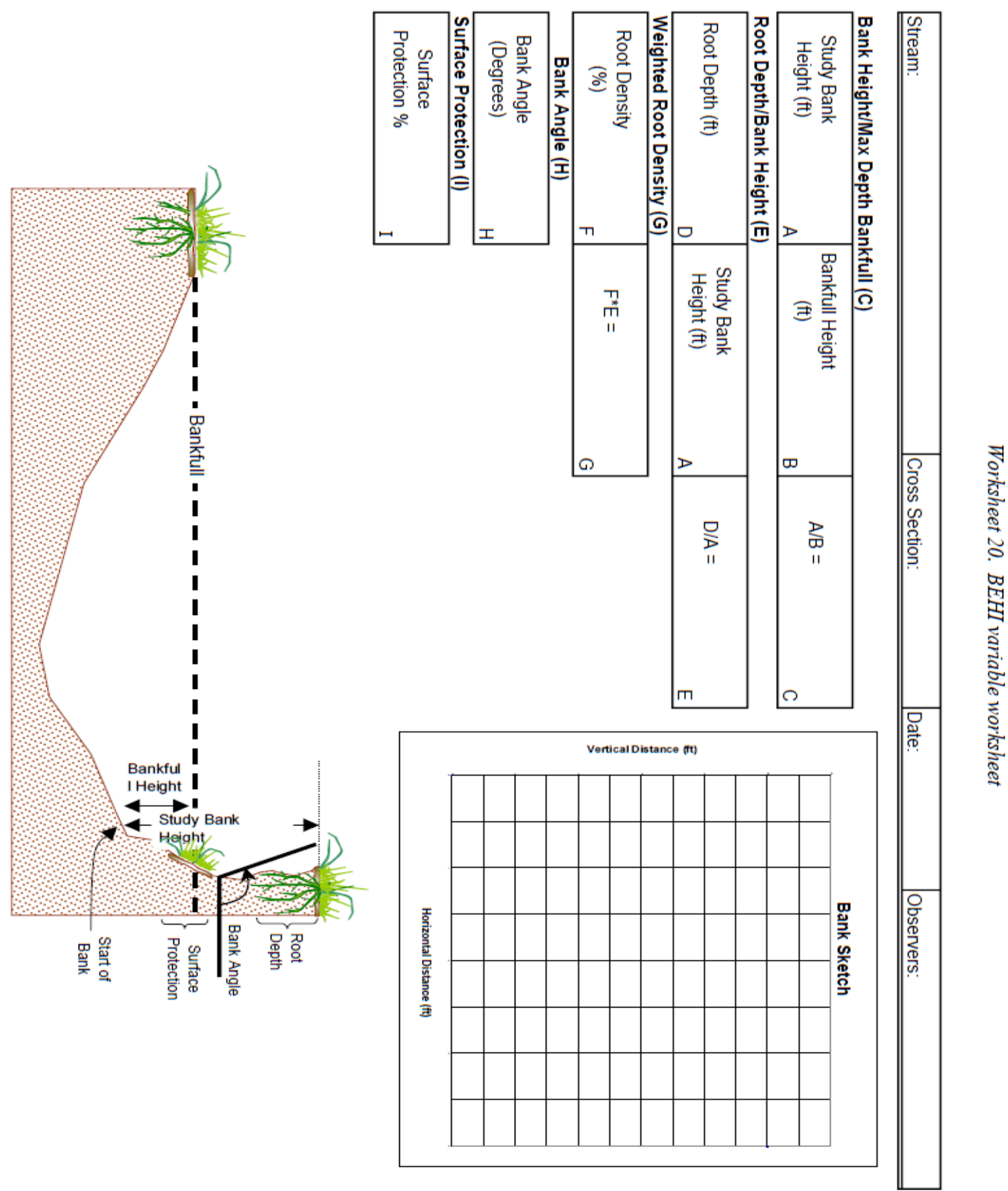
Worksheet 21. Summary of bank erosion hazard index (BEHI)

\begin{tabular}{|c|c|c|c|c|c|c|c|c|c|c|}
\hline & & & & Bank Ero & sio & n Hazard R & ting & Guide & & \\
\hline & Stream & & & Reach & & & & $\mathrm{Da}$ & & Crew \\
\hline & $\begin{array}{l}\text { Eank Helght (fi) } \\
\text { Bankful Helght }\end{array}$ & & & $\begin{array}{l}\text { ank Height' } \\
\text { Bankfull Ht }\end{array}$ & & $\begin{array}{l}\text { Coot Deptri } \\
\text { Bank Helght }\end{array}$ & & $\begin{array}{c}\text { Root } \\
\text { Density \% }\end{array}$ & $\begin{array}{c}\text { Bank Angle } \\
\text { (Degrees) }\end{array}$ & $\begin{array}{c}\text { Surface } \\
\text { Protection\% }\end{array}$ \\
\hline & & Value & & $1.0-1.1$ & & $1.0-0.9$ & & $100-80$ & $0-20$ & $100-80$ \\
\hline & VERY LOW & Index & & $1.0-1.9$ & & $1.0-1.9$ & & $1.0-1.9$ & $1.0-1.9$ & $1.0-1.9$ \\
\hline & & Choice & v: & I: & V: & $\mathrm{T}:$ & v: & $\mathrm{E}$ & $\mathrm{v}$ : & v: \\
\hline & & Value & & $1.11-1.19$ & & $0.89-0.5$ & & $79-55$ & $21-60$ & $79-55$ \\
\hline & Low & Index & & $2.0-3.9$ & & $2.0-3.9$ & & $2.0-3.9$ & $2.0-3.9$ & $2.0-3.9$ \\
\hline 9 & & Choice & v: & I: & $\mathrm{V}:$ & I: & $\mathrm{v}:$ & $\mathrm{I}:$ & v: & v: \\
\hline & & Value & & $12-1.5$ & & $0.49-0.3$ & & $54-30$ & $61-80$ & $54-30$ \\
\hline 5 & MODERATE & Index & & $4.0-5.9$ & & $4.0-5.9$ & & $4.0-5.9$ & $4.0-5.9$ & $4.0-5.9$ \\
\hline б & & Cholce & v: & I: & v: & $\mathrm{E}:$ & v: & I: & v: & v: \\
\hline$\frac{5}{6}$ & & Value & & $1.6-2.0$ & & 0.290 .15 & & $29-15$ & $81-90$ & $29-15$ \\
\hline 은 & HIGH & Index & & $6.0-7.9$ & & $6.0-7.9$ & & $6.0-7.9$ & $6.0-7.9$ & $6.0-7.9$ \\
\hline 羔 & & Choice & v: & I: & v: & I: & v: & $\mathrm{t}:$ & $\mathrm{v}$ : & v: \\
\hline & & Value & & $2.1-2.8$ & & $0.14-0.05$ & & $14-5.0$ & $91-119$ & $14-10$ \\
\hline & VERY HIGH & Index & & $8.0-9.0$ & & $8.0-9.0$ & & $8.0-9.0$ & $8.0-9.0$ & $8.0-9.0$ \\
\hline & & Cholce & v: & I: & V: & I: & v: & I: & v: & v: \\
\hline & & Value & & $>2.8$ & & $<0.05$ & & $<5$ & $>119$ & $<10$ \\
\hline & EXTREME & Index & & 10 & & 10 & & 10 & 10 & 10 \\
\hline & & Cholce & v: & I: & v: & t: & v: & I: & v: & v: \\
\hline & $1-$ value, $1=\ln$ & & & & & sUB- & TAL & Sum one ind & x from each colum & \\
\hline
\end{tabular}

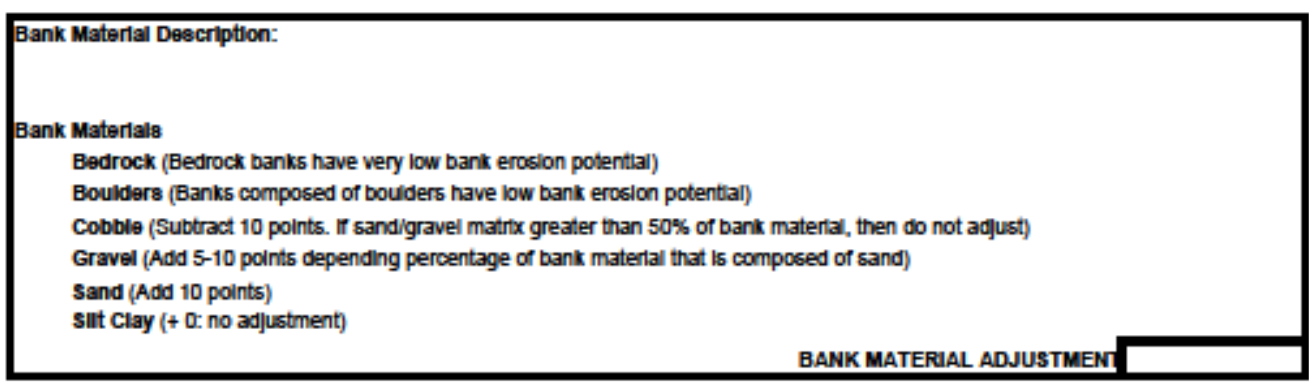

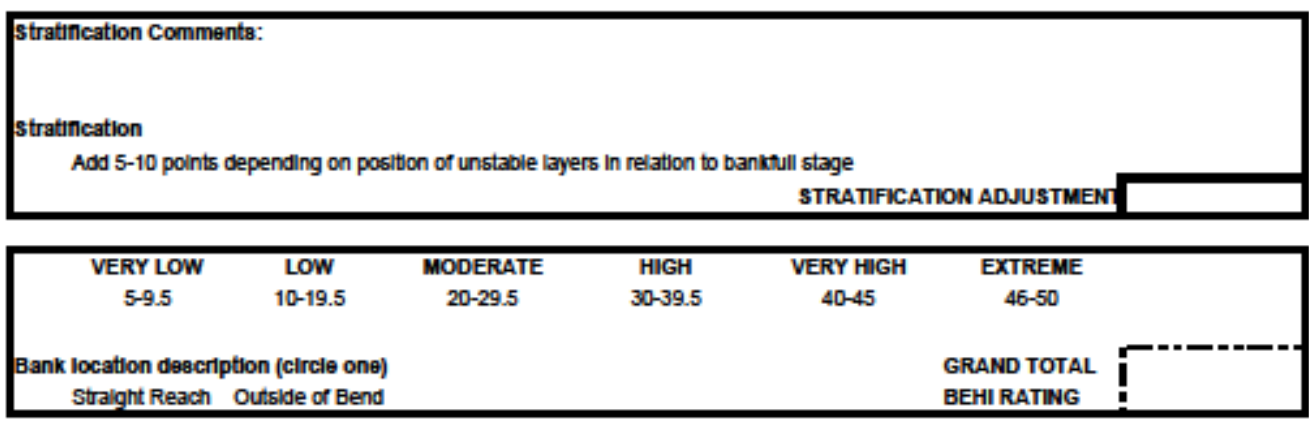


Appendix IIa. Diagram of a cross-section of a bankfull bench adapted from Doll and others (2003). The dotted line represents the old channel and the solid line represents the newly constructed channel. This is the general design used for priority three natural stream channel restoration, and was most similar to the approach used along a restored reach of the Cacapon River, West Virgnia.

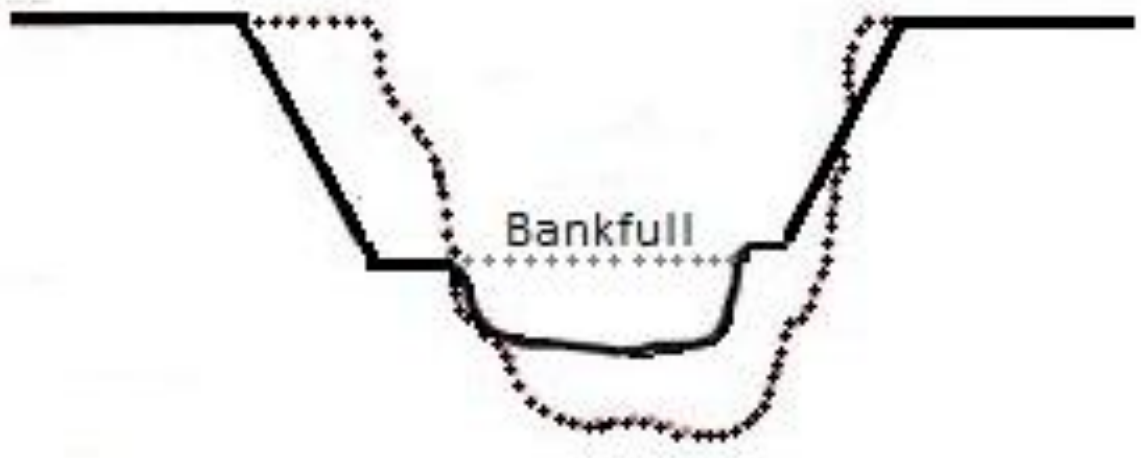


Appendix IIb. Aerial image with overlays showing location of reconstructed streambanks, in-stream structures, and site names in a reach of the Cacapon River, West Virginia selected for stream restoration.

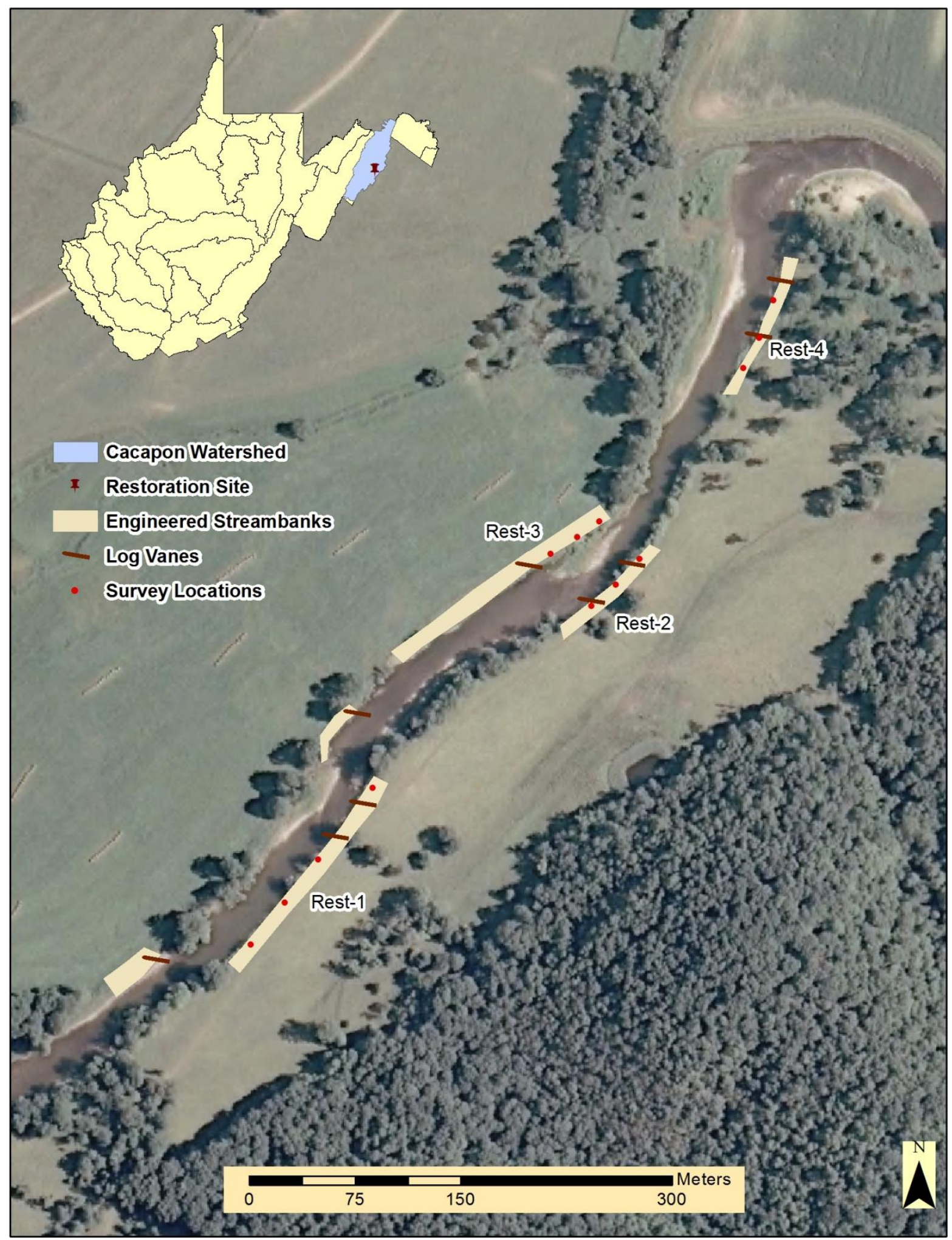


Appendix IIc. Map showing the location of sites chosen for assessing the effectiveness of stream restoration on improving riparian integrity and streambank stability.

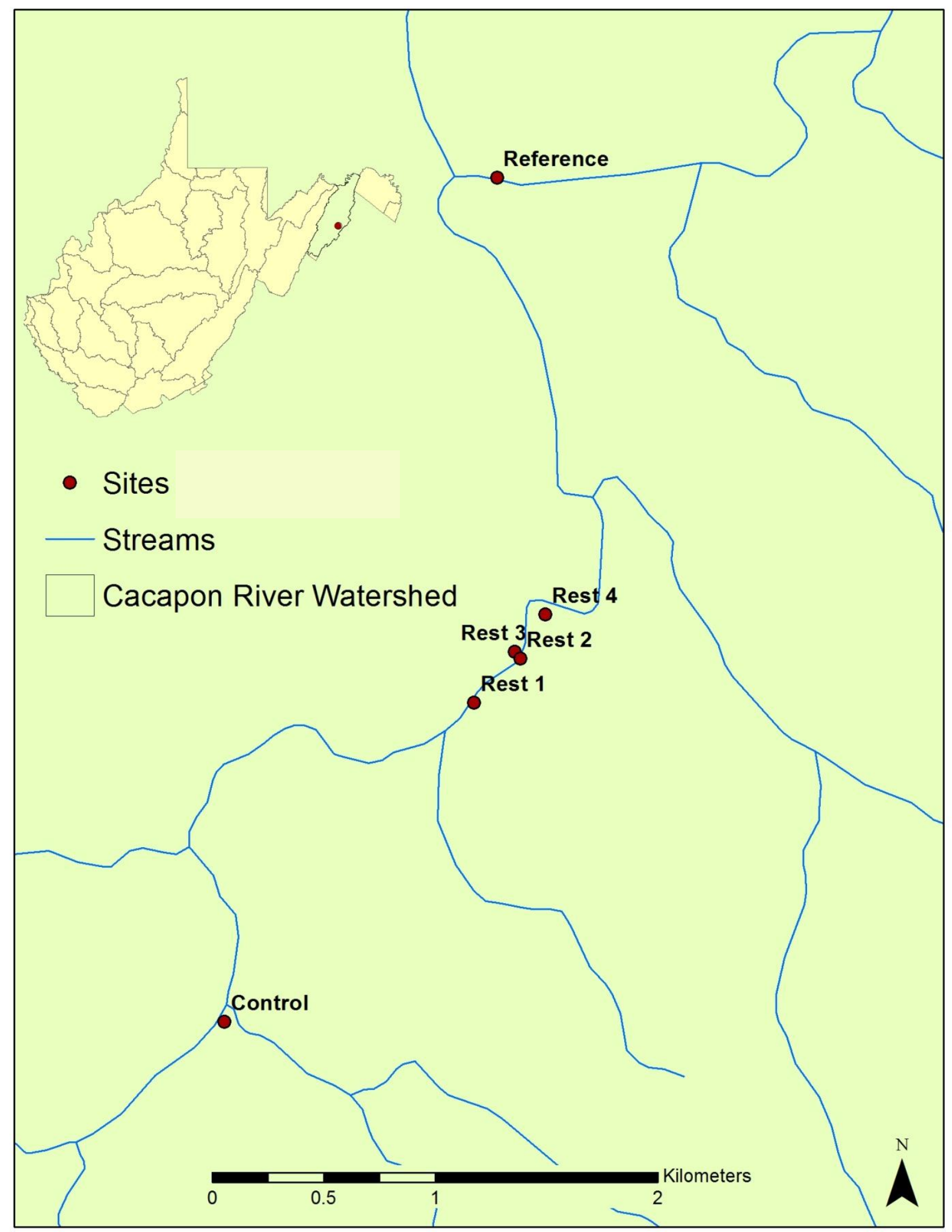


Appendix IId. Map showing the location of the Cacapon River Watershed and sites chosen to evaluate the effectiveness of stream restoration on water quality.

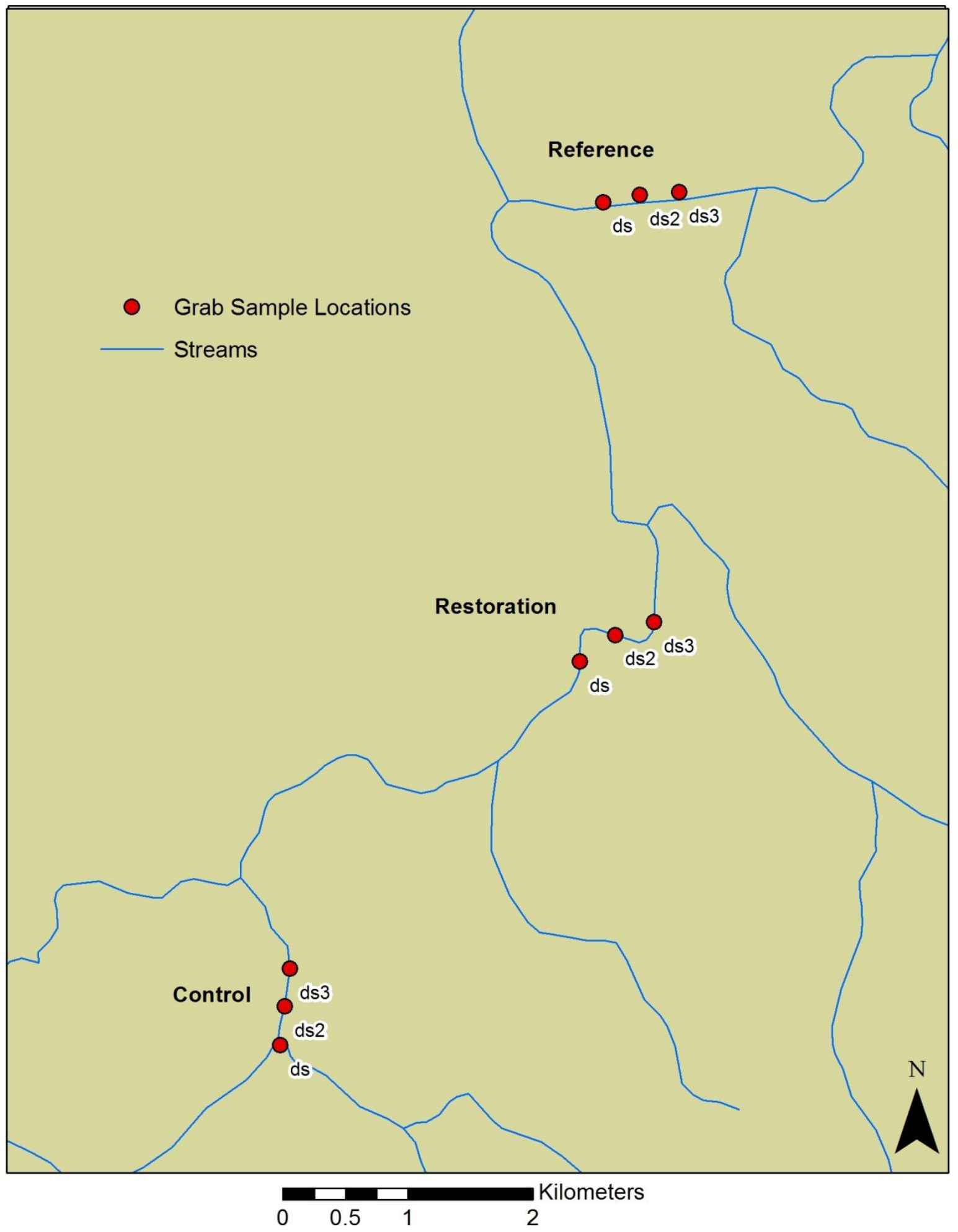


Appendix IIe. Map showing the location of Sondes for continuous monitoring of temperature, $\mathrm{pH}$, conductivity, turbidity, and stream depth upstream and downstream of a restored reach along the Cacapon River, West Virginia. The photo in the bottom right corner of the map shows a Sonde cabled to two cinder blocks, ready for deployment.

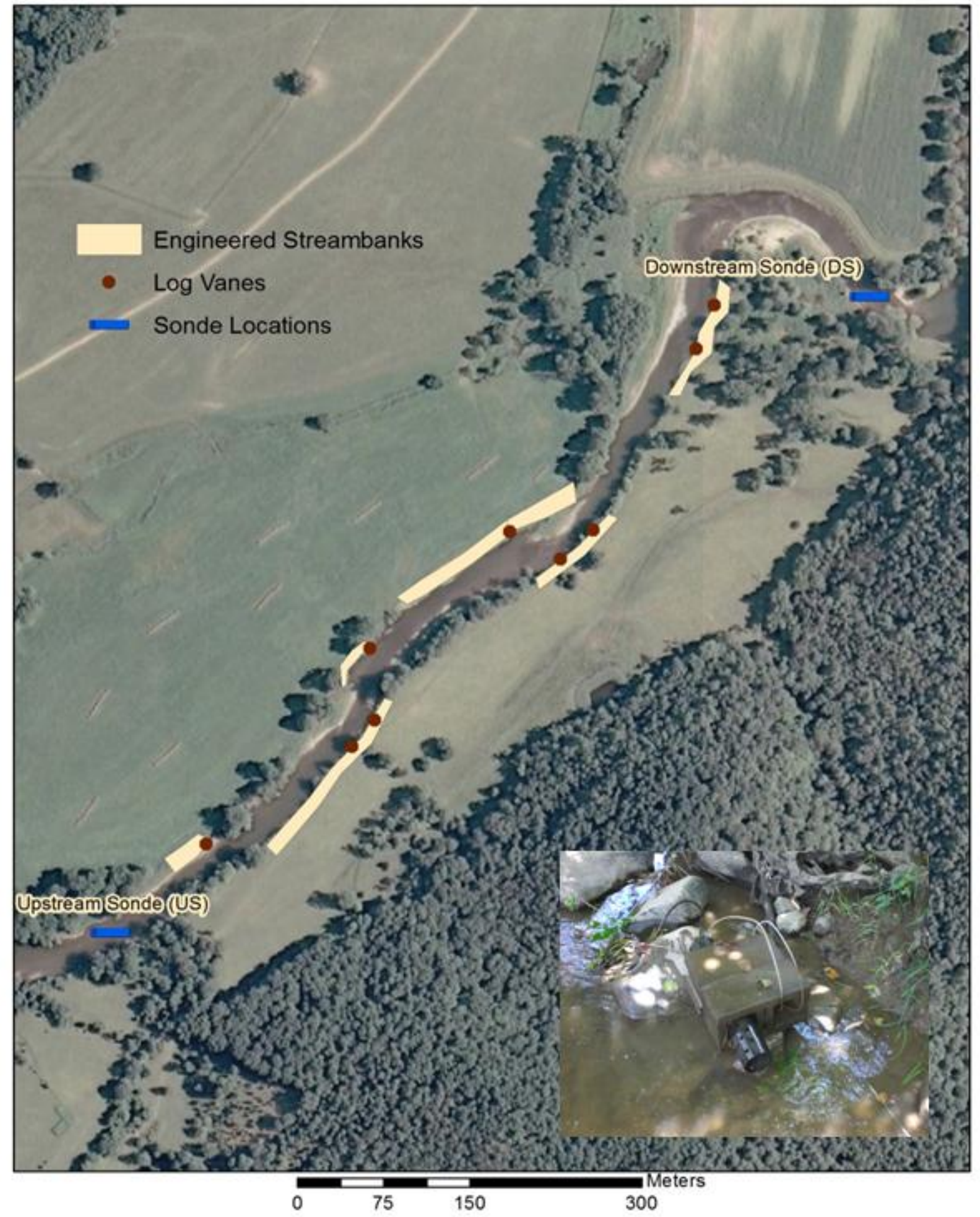


Appendix IIf. Map showing the location of the Cacapon River Watershed and sites chosen to evaluate the influence of riparian characteristics and soil composition on streambank migration rate.

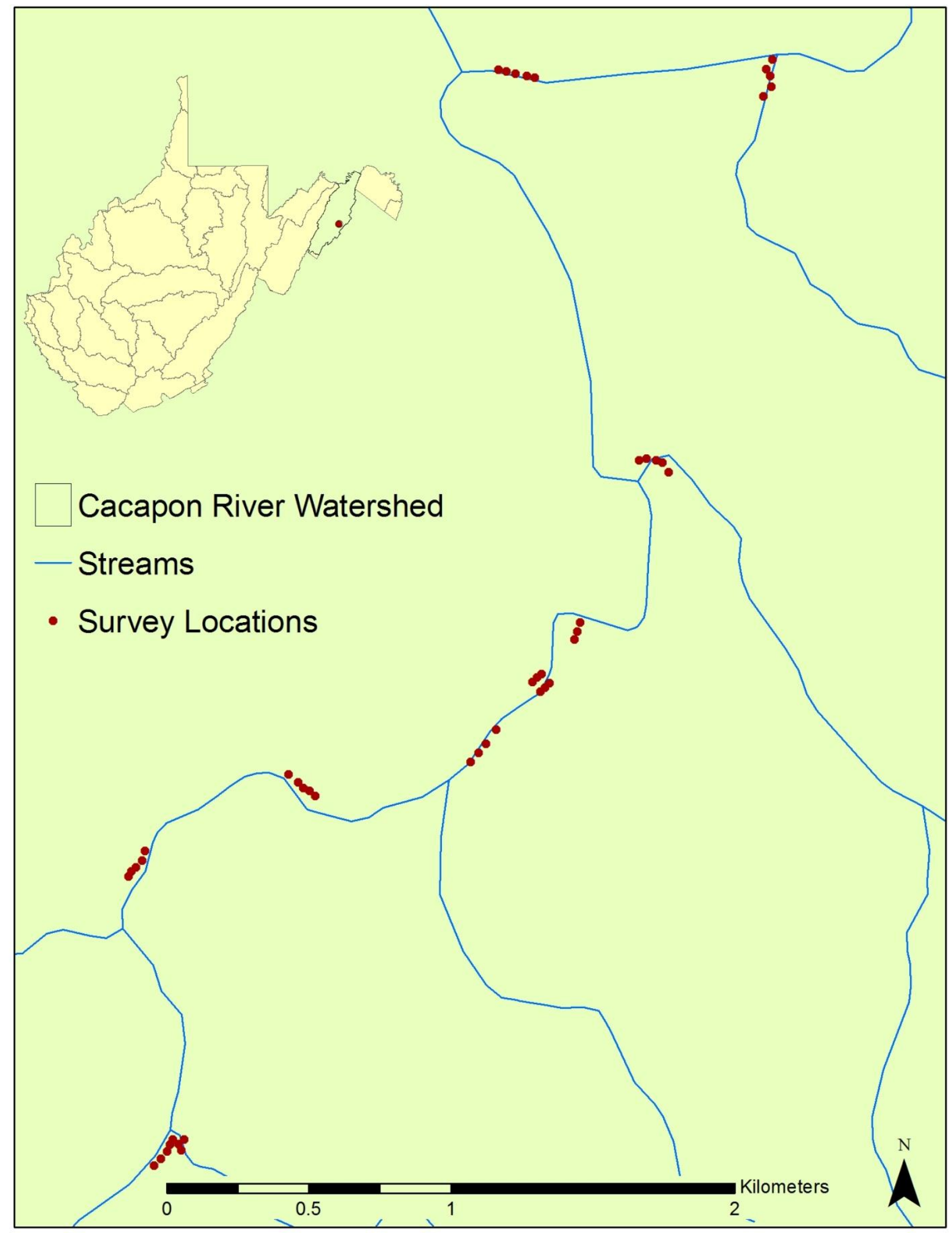


Appendix IIg. An example of a $25 \times 20$ meter quadrat used to evaluate the effects of restoration on riparian integrity on the Cacapon River, West Virginia. Each plot was centered on benchmarks established in the lower bank area used for streambank profile surveys. Woody vegetation within the larger quadrat (i.e., $25 \times 20$ m quadrat) was counted to species. Herbaceous vegetation was quantified within five evenly spaced $1 \times 1$ meter sub-plots along the top and toe of the bank using a cover class method to describe percent cover for each species and the percentage of bare ground.

\section{$25 \mathrm{~m}$}

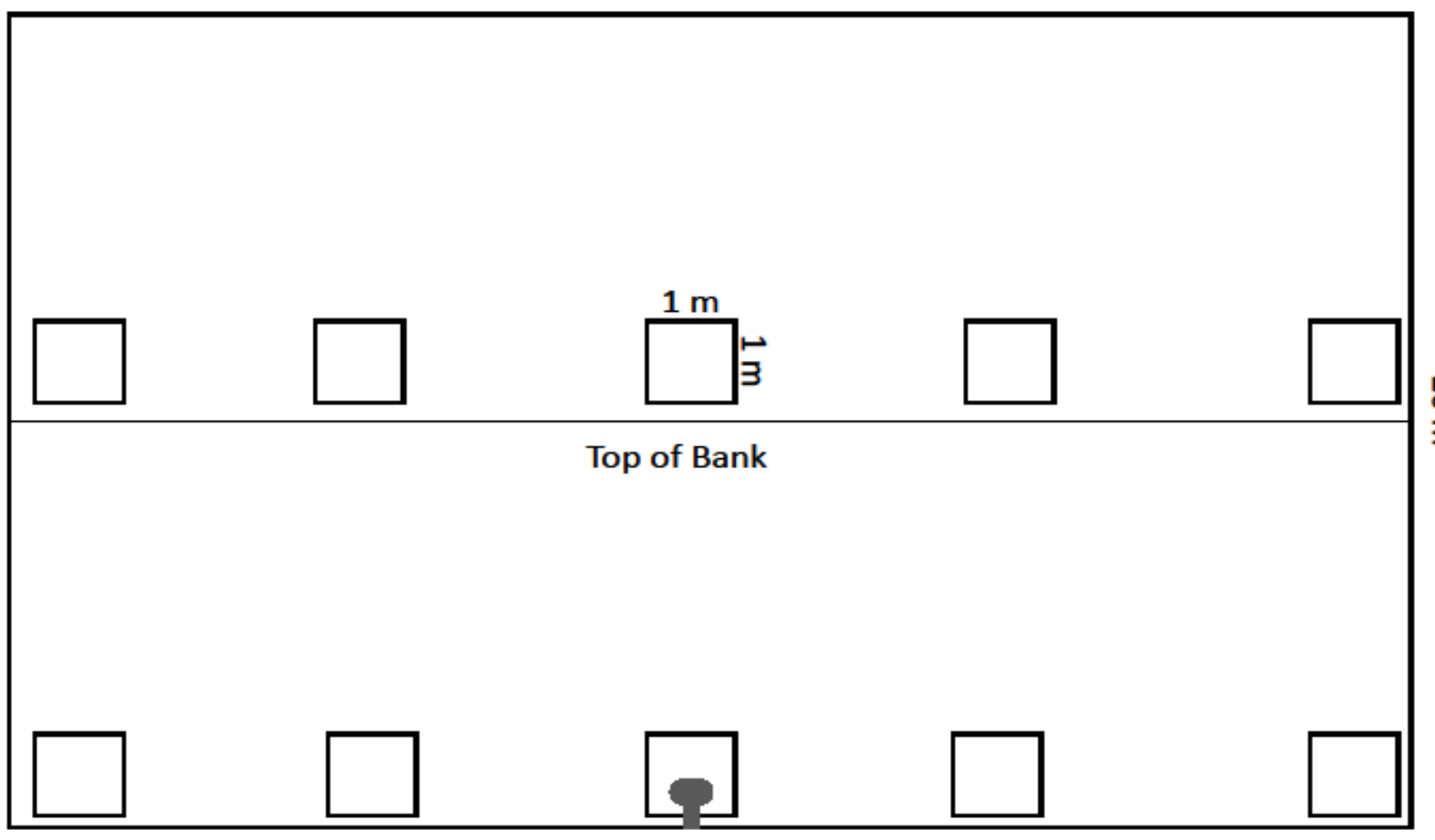

Toe of Bank 
Appendix IIh. Average Shannon-Wiener diversity of the herbaceous community in riparian areas along restored sub-reaches compared to a control and reference reach before (2009), immediately after (2010), and one year after (2011) stream restoration in the Cacapon River Watershed, West Virginia.

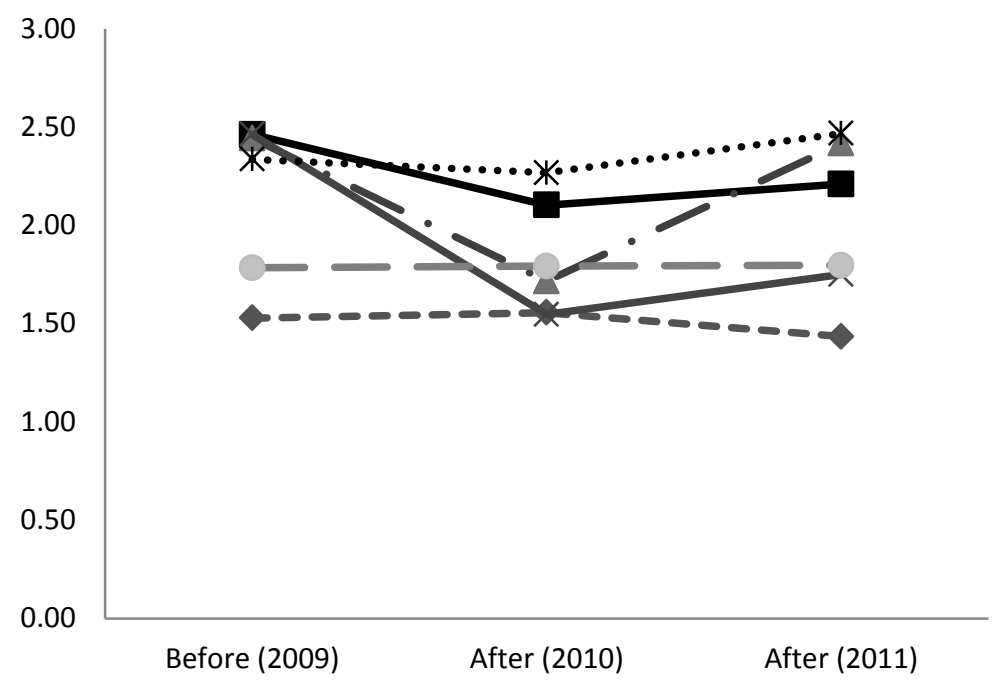

Appendix IIi. Average concentration of nitrates $\left(\mathrm{NO}_{3}\right)$ before $(6 / 2009-4 / 2010)$ and after $(6 / 2010-$ 12/2011) stream restoration along a reach of the Cacapon River, West Virginia compared to a control and reference reach.

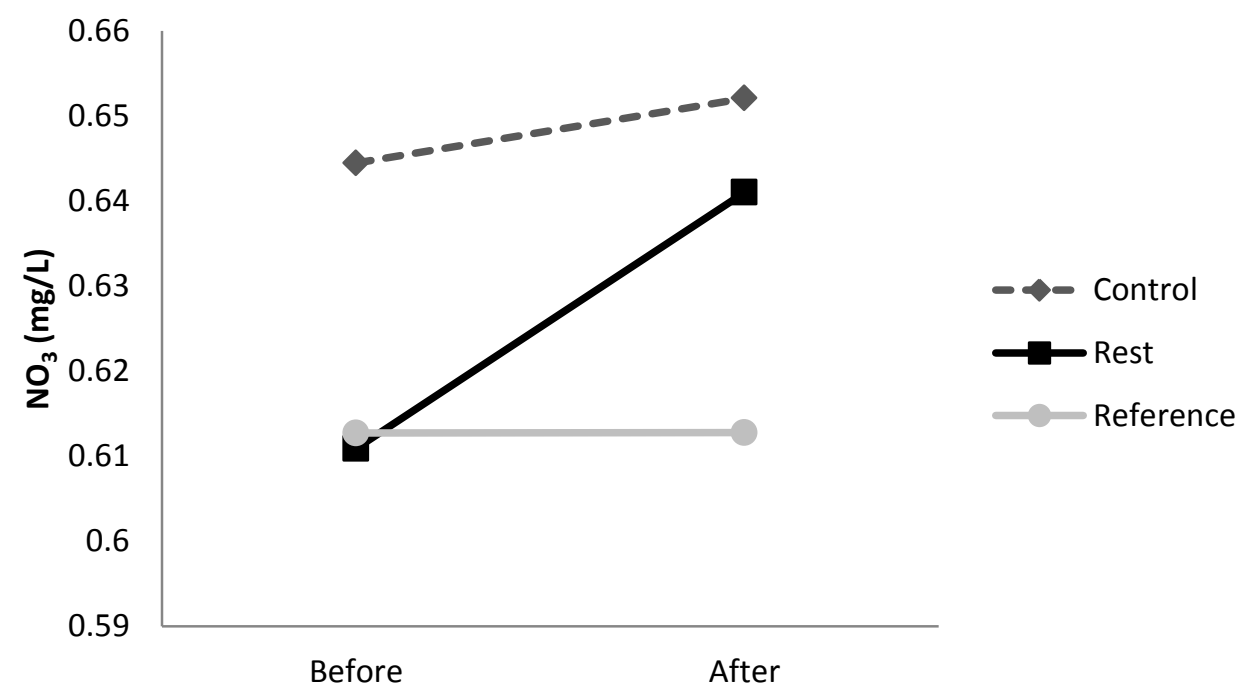


Appendix IIj. Average concentration of ammonia $\left(\mathrm{NH}_{3}\right)$ before $(6 / 2009-4 / 2010)$ and after $(6 / 2010$ 12/2011) stream restoration along a reach of the Cacapon River, West Virginia compared to a control and reference reach.

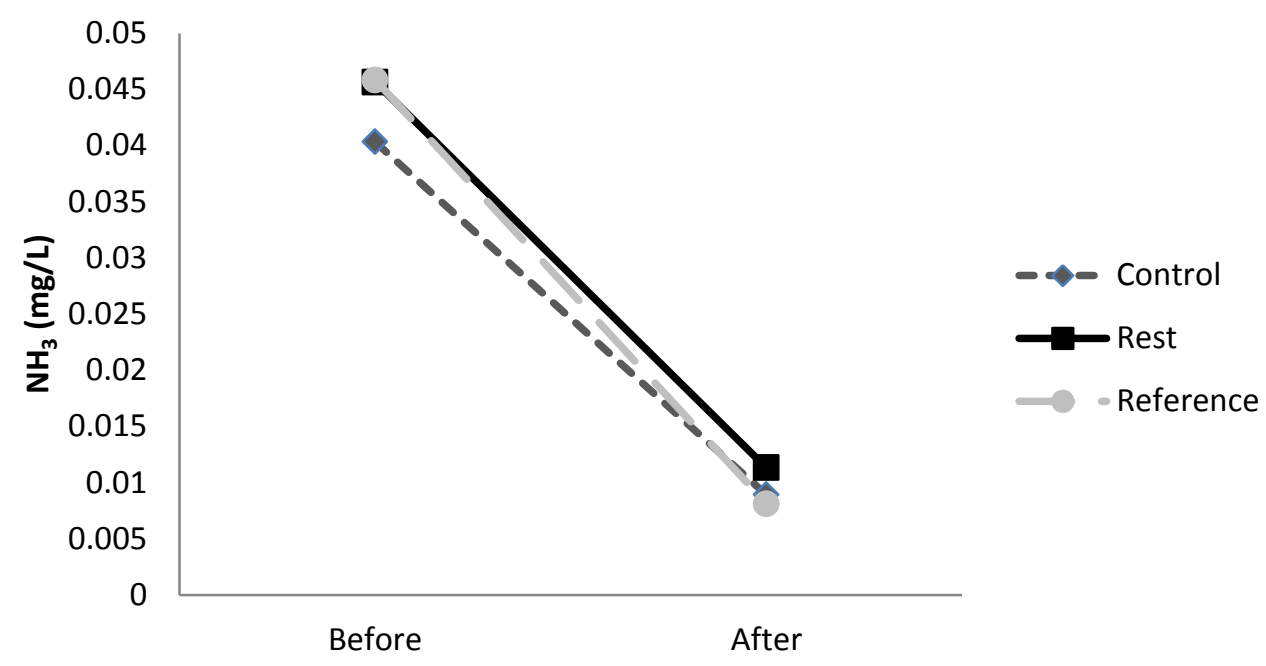

Appendix IIk. Average concentration of total phosphorus (P) before (6/2009 - 4/2010) and after (6/2010 12/2011) stream restoration along a reach of the Cacapon River, West Virginia compared to a control and reference reach.

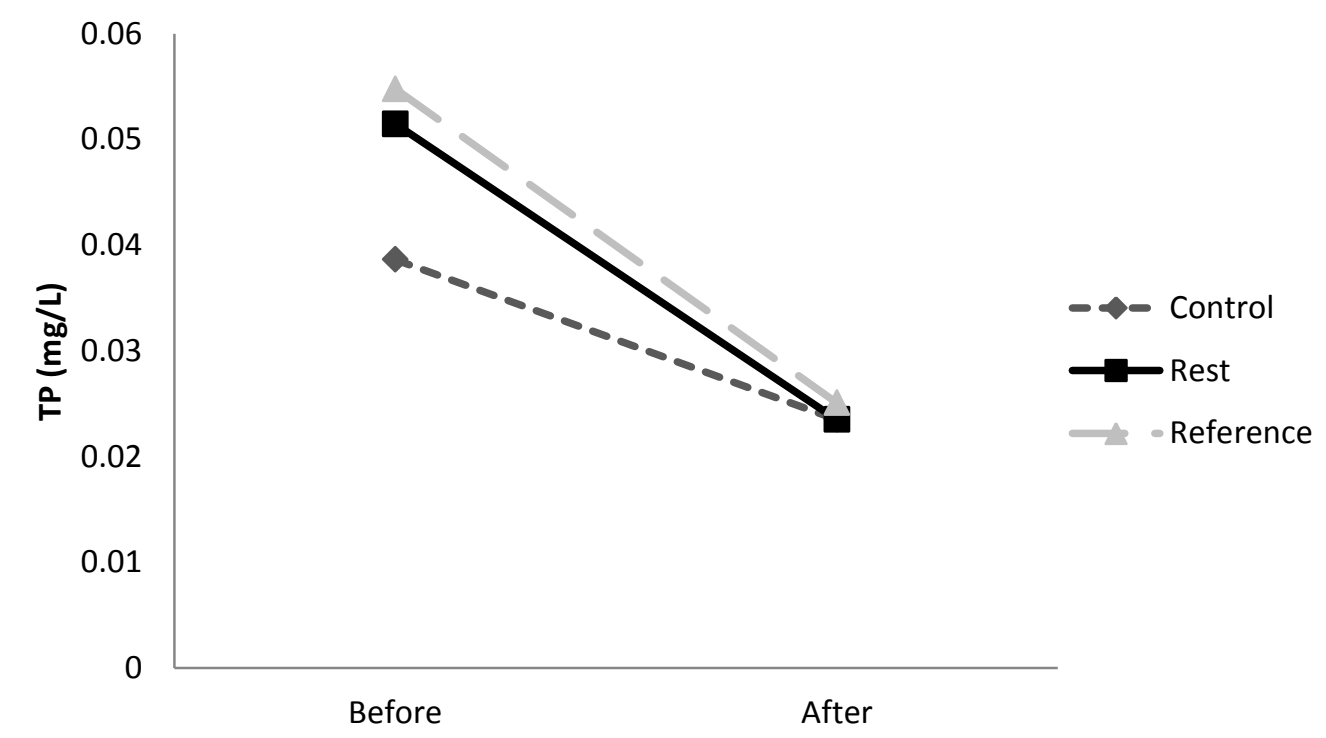


Appendix IIl. Average concentration of total suspended solids (TSS) before (6/2009 - 4/2010) and after $(6 / 2010$ - 12/2011) stream restoration along a reach of the Cacapon River, West Virginia compared to a control and reference reach.

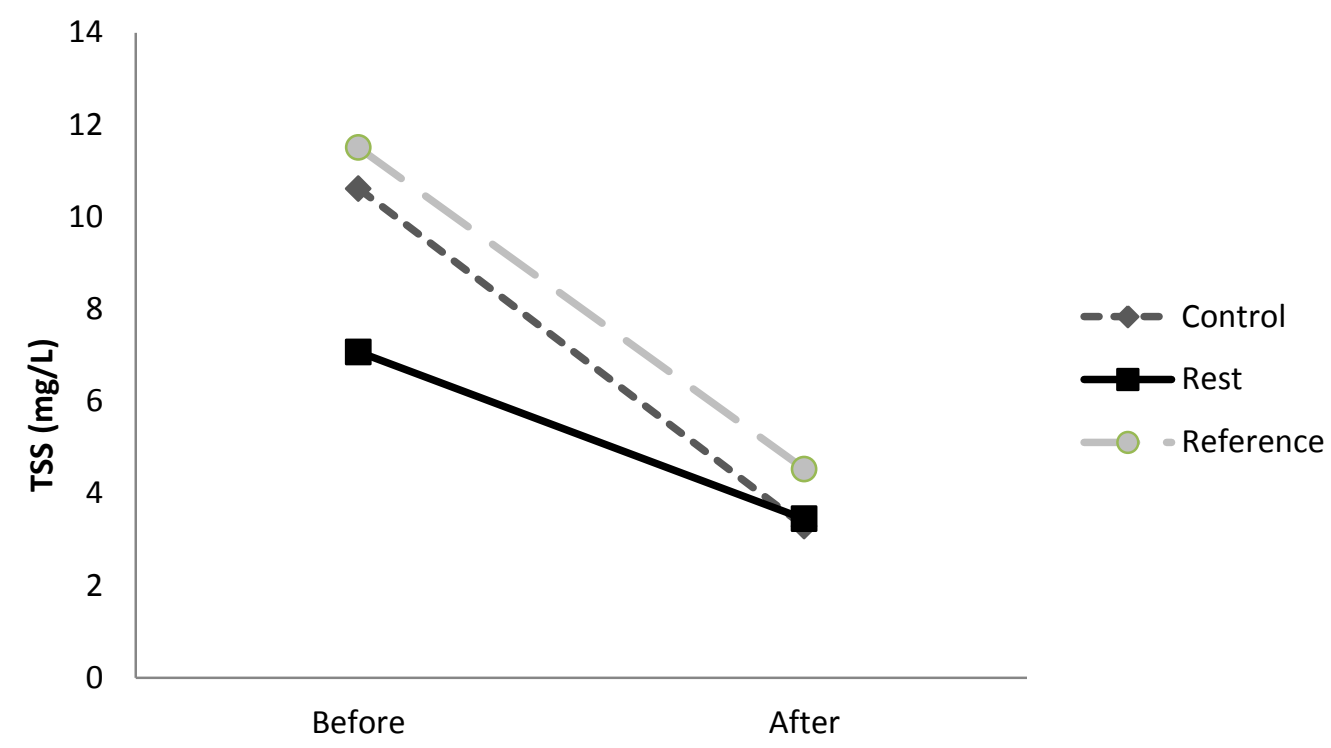


Appendix IIIa. Pfankuch stream reach inventory and channel stability evaluation used to locate areas in fair or poor condition in the Cacapon River Watershed, West Virginia where erosion rates were measured from 2010 - 2011 in development of a model of streambank erosion potential (SEP).

\begin{tabular}{|c|c|c|c|c|c|c|c|c|}
\hline \multirow{2}{*}{$\begin{array}{l}\text { UPPER BANKS } \\
\text { Landform slope }\end{array}$} & \multicolumn{2}{|l|}{ EXCELLENT } & \multicolumn{2}{|l|}{ GOOD } & \multicolumn{2}{|l|}{ FAIR } & \multicolumn{2}{|l|}{ POOR } \\
\hline & Bank slope gradient $<30 \%$ & 2 & $\begin{array}{l}\text { Bank slope gradient } 30 \text { - } \\
40 \%\end{array}$ & 4 & $\begin{array}{l}\text { Bank slope gradient } 40- \\
60 \%\end{array}$ & 6 & $\begin{array}{l}\text { Bank slope gradient } \\
>60 \%\end{array}$ & 8 \\
\hline $\begin{array}{l}\text { Mass-wasting } \\
\text { (existing or potential) }\end{array}$ & $\begin{array}{l}\text { No evidence of post or any } \\
\text { potential for future mass- } \\
\text { wasting into channel. }\end{array}$ & 3 & $\begin{array}{l}\text { Infrequent and/or very } \\
\text { small. Mostly healed over. } \\
\text { Low future potential. }\end{array}$ & 6 & $\begin{array}{l}\text { Moderate frequency and } \\
\text { size, with some raw spots } \\
\text { eroded by water during } \\
\text { high flows. }\end{array}$ & 9 & $\begin{array}{l}\text { Frequent or large, } \\
\text { causing sediment OR } \\
\text { imminent danger of } \\
\text { same. }\end{array}$ & 12 \\
\hline $\begin{array}{l}\text { Debris jam potential } \\
\text { (floatable objects) }\end{array}$ & $\begin{array}{l}\text { Essentially absent from } \\
\text { immediate channel area. }\end{array}$ & 2 & $\begin{array}{l}\text { Present but mostly small } \\
\text { twigs and limbs. }\end{array}$ & 4 & $\begin{array}{l}\text { Present, volume and size } \\
\text { are both increasing, }\end{array}$ & 6 & $\begin{array}{l}\text { Moderate to heavy } \\
\text { amounts, mainly larger } \\
\text { sizes. }\end{array}$ & 8 \\
\hline $\begin{array}{l}\text { Vegetative bank } \\
\text { protection }\end{array}$ & $\begin{array}{l}>90 \% \text { plant density. Vigor } \\
\text { and variety suggests a deep, } \\
\text { dense, soil binding root } \\
\text { mass. }\end{array}$ & 3 & $\begin{array}{l}70-90 \% \text { density. Fewer } \\
\text { plant species or lower vigor } \\
\text { suggests a less dense or } \\
\text { deep root mass. }\end{array}$ & 6 & $\begin{array}{l}50-70 \% \text { density. Lower } \\
\text { vigor and species form a } \\
\text { somewhat shallow and } \\
\text { discontinuous root mass. }\end{array}$ & 9 & \begin{tabular}{|l|}
$<50 \%$ density plus \\
fewer species and vigor \\
indicate discontinuous \\
and shallow root mass.
\end{tabular} & 12 \\
\hline $\begin{array}{l}\text { Channel capacity } \\
\text { LOWER BANKS }\end{array}$ & $\begin{array}{l}\text { Ample for present plus some } \\
\text { increases. Peak flows } \\
\text { contained. Width to Depth } \\
\text { (W/D) ratio }<7 \text {. }\end{array}$ & 1 & $\begin{array}{l}\text { Adequate. Overbank flows } \\
\text { rare. } \\
\text { W/D ratio } 8 \text { to } 15 \text {. }\end{array}$ & 2 & $\begin{array}{l}\text { Barely contains present } \\
\text { peaks. Occasional over- } \\
\text { bank floods. } \\
\text { W/D ratio } 15 \text { to } 25 \text {. }\end{array}$ & 3 & $\begin{array}{l}\text { Inadequate. Overbank } \\
\text { flows common. } \\
\text { W/D ratio }>25 \text {. }\end{array}$ & 4 \\
\hline Bank rock content & $\begin{array}{l}65 \% \text { with large, angular } \\
\text { boulders } 30 \mathrm{~cm} \text { numerous. }\end{array}$ & 2 & $\begin{array}{l}40 \text { to } 65^{\prime} \% \text {, mostly small } \\
\text { boulders to cobbles } 15- \\
30 \mathrm{~cm} .\end{array}$ & 4 & $\begin{array}{l}20 \text { to } 401 \text {, with most in the } \\
7.5-15 \mathrm{~cm} \text { diameter class. }\end{array}$ & 6 & $\begin{array}{l}<20 \% \text { rock fragments of } \\
\text { gravel sizes, } 2.5-7.5 \mathrm{~cm} \\
\text { or less. }\end{array}$ & 8 \\
\hline $\begin{array}{l}\text { Obstructions } \\
\text { (flow deflectors } \\
\text { Sediment traps) }\end{array}$ & $\begin{array}{l}\text { Rocks and old logs firmly } \\
\text { embedded. Flow pattern } \\
\text { without cutting or deposition. } \\
\text { Pools and riffles stable. }\end{array}$ & 2 & $\begin{array}{l}\text { Some present, causing } \\
\text { erosive cross currents and } \\
\text { minor pool filling. } \\
\text { Obstructions and deflectors } \\
\text { newer and less firm. }\end{array}$ & 4 & $\begin{array}{l}\text { Moderately frequent, } \\
\text { unstable obstructions and } \\
\text { deflectors move with high } \\
\text { water causing bank cutting } \\
\text { and filling of pools. }\end{array}$ & 6 & \begin{tabular}{|l|} 
Frequent obstructions \\
and deflectors cause \\
bank erosion. Sediment \\
traps' full channel \\
migration occurring.
\end{tabular} & 8 \\
\hline Undercutting & $\begin{array}{l}\text { Little or none evident. } \\
\text { Infrequent raw banks } \\
<150 \mathrm{~cm} \text { high. }\end{array}$ & 4 & $\begin{array}{l}\text { Some, intermittently at } \\
\text { outcurves and constrictions. } \\
\text { Raw banks }<30 \mathrm{~cm} \text {. }\end{array}$ & 8 & $\begin{array}{l}\text { Significant. Cuts } 15-30 \mathrm{~cm} \\
\text { high. Root mat overhangs } \\
\text { and sloughing evident. }\end{array}$ & 12 & \begin{tabular}{|l|} 
Almost continuous cuts, \\
some $>30 \mathrm{~cm}$ high. \\
Failure of overhangs
\end{tabular} & 16 \\
\hline Deposition & \multirow{2}{*}{$\begin{array}{l}\text { Little or no enlargement of } \\
\text { channel or point bars. }\end{array}$} & \multirow[t]{2}{*}{4} & \multirow{2}{*}{$\begin{array}{l}\text { Some new increase in bar } \\
\text { formation, mostly from } \\
\text { coarse gravels. }\end{array}$} & \multirow[t]{2}{*}{8} & \multirow{2}{*}{$\begin{array}{l}\text { Moderate deposition of new } \\
\text { gravel and coarse sand on } \\
\text { old and some new bars. }\end{array}$} & \multirow[t]{2}{*}{12} & \multirow{2}{*}{$\begin{array}{l}\text { Extensive deposits of } \\
\text { predominantly fine } \\
\text { particles. Accelerated }\end{array}$} & \multirow[t]{2}{*}{16} \\
\hline STREAM BED & & & & & & & & \\
\hline Rock angularity & $\begin{array}{l}\text { Sharp edges and corners, } \\
\text { plane surfaces roughened. }\end{array}$ & 1 & $\begin{array}{l}\text { Rounded corners and } \\
\text { edges. Smooth and flat. }\end{array}$ & 2 & $\begin{array}{l}\text { Corners and edges wel1 } \\
\text { rounded in two dimensions. }\end{array}$ & 3 & $\begin{array}{l}\text { Well rounded in all } \\
\text { dimensions. }\end{array}$ & 4 \\
\hline Brightness & $\begin{array}{l}\text { Surfaces dull, darkened or } \\
\text { stained. Not "bright". }\end{array}$ & 1 & $\begin{array}{l}\text { Mostly dull, but may have } \\
\text { up to } 35 \% \text { bright surfaces. }\end{array}$ & 2 & $\begin{array}{l}\text { Mixture, } 50-50 \% \text { dull and } \\
\text { bright i.e. } 35-65 \% \text {. }\end{array}$ & 3 & \begin{tabular}{|l|} 
Predominantly bright, \\
$65 \%$, exposed surfaces.
\end{tabular} & 4 \\
\hline $\begin{array}{l}\text { Consolidation or } \\
\text { particle packing }\end{array}$ & $\begin{array}{l}\text { Assorted sizes tightly packed } \\
\text { and/or overlapping. }\end{array}$ & 2 & $\begin{array}{l}\text { Moderately packed with } \\
\text { some overlapping. }\end{array}$ & 4 & $\begin{array}{l}\text { Mostly a loose assortment } \\
\text { with no apparent overlap. }\end{array}$ & 6 & $\begin{array}{l}\text { No packing evident. } \\
\text { Loose, easily moved. }\end{array}$ & 8 \\
\hline $\begin{array}{l}\text { Bottom size } \\
\text { distribution \& stable }\end{array}$ & $\begin{array}{l}\text { No change in sizes evident. } \\
\text { Stable materials } 80-100 \%\end{array}$ & 4 & $\begin{array}{l}\text { Distribution shift slight. } \\
\text { Stable materials } 50-80 \% \text {. }\end{array}$ & 8 & $\begin{array}{l}\text { Moderate change in sizes. } \\
\text { Stable materials } 20-50 \%\end{array}$ & 12 & $\begin{array}{l}\text { Marked change. Stable } \\
\text { materials } 0-20 \%\end{array}$ & 16 \\
\hline $\begin{array}{l}\text { Scouring and } \\
\text { deposition }\end{array}$ & $\begin{array}{l}<5 \% \text { of the bottom affected } \\
\text { by scouring and deposition. }\end{array}$ & 6 & $\begin{array}{l}\text { 5-30\% affected. Scour at } \\
\text { constrictions and where } \\
\text { steep. Pool deposition. }\end{array}$ & 12 & $\begin{array}{l}30-50 \% \text { affected. Deposits } \\
\text { and scour at obstructions, } \\
\text { constrictions, and bends. }\end{array}$ & 18 & $\begin{array}{l}>50 \% \text { of bed in a state } \\
\text { of flux or change nearly } \\
\text { year-long. }\end{array}$ & 24 \\
\hline $\begin{array}{l}\text { Clinging aquatic } \\
\text { vegetation } \\
\text { (moss and algae) }\end{array}$ & $\begin{array}{l}\text { Abundant, growth largely } \\
\text { moss, dark green, perennial. } \\
\text { In swift water too. }\end{array}$ & 1 & $\begin{array}{l}\text { Common. Algal forms in } \\
\text { low velocity and pool areas. } \\
\text { Moss and swifter waters. }\end{array}$ & 2 & $\begin{array}{l}\text { Present but spotty, mostly } \\
\text { in backwater areas. } \\
\text { Seasonal blooms }\end{array}$ & 3 & $\begin{array}{l}\text { Perennial types scarce } 4 \\
\text { or absent. Yellow-green, } \\
\text { short term bloom present }\end{array}$ & \\
\hline COLUMN TOTALS & & & & & & & & \\
\hline
\end{tabular}

